
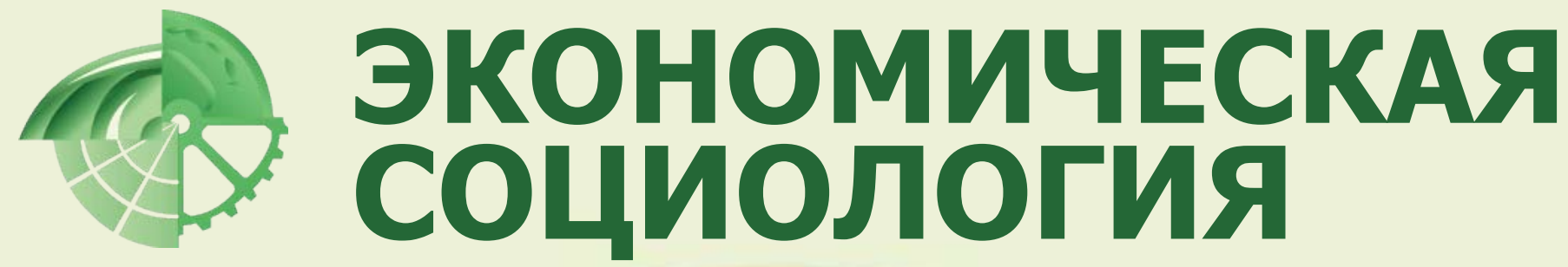

JOURNAL OF ECONOMIC SOCIOLOGY = EKONOMICHESKAYA SOTSIOLOGIYA

Читайте в номере:

Interview with Gabriel Abend "The Moral Background Makes the Play of Life Possible"

Бердышева Е. Дифференциация «привлекательности» правонарушений в восприятии российских полицейских

Де Ваан М., Ведреш Б., Старк Д. Игры-события: топология креативности

Боулз С. Моральная экономика: почему хорошие стимулы не заменят хороших граждан 


\section{Экономическая}

социология

Т. 17. № 4.

Сентябрь 2016

Электронный журнал www.ecsoc.msses.ru www.ecsoc.hse.ru

ISSN 1726-3247

\section{Адрес редакции}

101000, Россия,

г. Москва,

ул. Мясницкая,

д. 20, комн. 406

тел.: +7 (495) 628-48-86

email: ecsoc@hse.ru

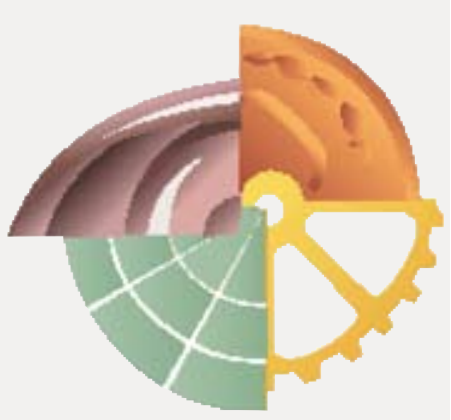

Journal of Economic Sociology Vol. 17. No 4.

September 2016

Electronic journal www.ecsoc.msses.ru www.ecsoc.hse.ru

ISSN 1726-3247

\section{Contacts}

20 Myasnitskaya street, room 406

Moscow, 101000

Russian Federation phone: +7 (495) 628-48-86 email: ecsoc@hse.ru лектронный журнал «Экономическая социология» издаётся с 2000 г. Учредителями являются Национальный исследовательский университет «Высшая школа экономики» (с 2007 г.) и Вадим Валерьевич Радаев (главный редактор).

Цель журнала - утверждать международные стандарты экономико-социологических исследований в России, представлять современные работы российских и зарубежных авторов в области экономической социологии, информировать профессиональное сообщество о новых актуальных публикациях и исследовательских проектах, а также вовлекать в профессиональное сообщество молодых коллег.

Журнал представляет собой специализированное академическое издание. В нём публикуются материалы, отражающие современное состояние экономической социологии и способствующие развитию данной области в её современном понимании. В числе приоритетных тем: теоретические направления экономической социологии, социологические исследования рынков и организаций, социально-экономические стратегии индивидов и домашних хозяйств, неформальная экономика. Также публикуются тексты из смежных дисциплин - неоинституциональной экономической теории, антропологии, экономической психологии и других областей, которые могут представлять интерес для экономсоциологов.

Журнал публикует пять номеров в год: в январе, марте, мае, сентябре и ноябре. Доступ ко всем номерам журнала постоянный, свободный и бесплатный по адресу: http:// www.ecsoc.hse.ru. Каждый номер содержится в едином файле (10-12 п. л. в PDF).

Журнал входит в список ВАК России, индексируется в Российском индексе научного цитирования (РИНЦ) и Emerging Sources Citation Index (ESCI) из Web of Science Core Collection.

Требования к авторам изложены по адресу: http://ecsoc.hse.ru/author_requirements. html

В журнале применяется двойное анонимное рецензирование статей. Все материалы проходят через полный цикл редакторской обработки и корректуры.

Плата с авторов журнала не взимается. Ускоренные сроки публикации статей не предусмотрены.

Tournal of Economic Sociology was established in 2000 as one of the first academic e-journals in Russia. It is funded by the National Research University Higher School of Economics (HSE).

Journal of Economic Sociology promotes international standards of research in economic sociology, presenting new research carried out by Russian and international scholars, introducing new books and research projects, and attracting young scholars into the field.

Journal of Economic Sociology is a specialized academic journal representing the mainstreams of thinking and research in international and Russian economic sociology. Journal of Economic Sociology provides a framework for discussion of the following key issues: major theoretical paradigms in economic sociology, sociology of markets and organizations, social and economic strategies of households, informal economy. Journal of Economic Sociology also welcomes research papers written within neighboring disciplines - new institutional economics, anthropology, economic psychology and related fields, which can be of interest for economic sociologists.

Journal of Economic Sociology has a wide Russian speaking audience, living both in Russia and abroad. Its main target group comprises research scholars, university professors, policy-makers, post-graduates, undergraduates and others who are interested in economic sociology.

Journal of Economic Sociology is indexed by Emerging Sources Citation Index (ESCI) from Web of Science ${ }^{\mathrm{TM}}$ Core Collection.

Journal of Economic Sociology is a bimonthly journal released in five issues (January, March, May, September, and November). Journal of Economic Sociology provides permanent free access to all issues in PDF. Journal of Economic Sociology applies blind peer-review procedures (two referees for each research paper). All papers are subject to editing, proofreading, and professional design layout.

Guidelines for authors: http://ecsoc.hse.ru/author_requirements.html 
Экономическая

социология

Т. 17. № 4.

Сентябрь 2016

Электронный журнал www.ecsoc.msses.ru www.ecsoc.hse.ru

\section{ISSN 1726-3247}

Журнал выходит

пять раз в год:

№ 1 - январь

№ 2 - март

№ 3 - май

№ 4 - сентябрь

№ 5 - ноябрь

Учредители:

- Национальный исследовательский университет «Высшая школа экономики»

- В. В. Радаев

Издаётся с 2000 года

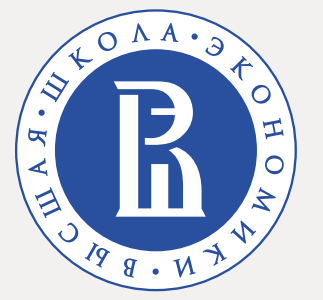

НАЦИОНАЛЬНЫЙ ИССЛЕДОВАТЕЛЬСКИЙ УНИВЕРСИТЕТ

\section{Редакция}

Главный редактор:

Редактор выпуска:

Вёрстка:

Корректор:

Ответственный

секретарь:

Сотрудники

редакции:
Радаев Вадим Валерьевич (НИУ ВШЭ, Россия)

Соколова Татьяна Виленовна (НИУ ВШЭ, Россия)

Мишина Мария Евгеньевна (Россия)

Андрианова Надежда Викторовна (НИУ ВШЭ, Россия)

Котельникова Зоя Владиславовна (НИУ ВШЭ, Россия)

Назарбаева Елена Алексеевна (НИУ ВШЭ, Россия)

Конрой Наталья Викторовна (НИУ ВШЭ, Россия)

\section{Международный редакционный совет}

Ашвин Сара

(Ashwin, Sarah)

Гербер Тед

(Gerber, Ted)

Гусева Аля (Guseva, Alya)

Зависка Джейн (Zavisca, Jane)

Линднер Петер

(Lindner, Peter)

Сводер Кристофер

(Swader, Christopher)

Якубович Валерий

(Yakubovich, Valery)
Лондонская школа экономики и политических наук

(Великобритания)

Висконсинский университет в Мэдисоне

(США)

Университет Бостона (США)

Университет Аризоны (США)

Университет Франкфурта-на-Майне

им. И. В. Гёте (Германия)

Лундский университет (Швеция)

Бизнес-школа ESSEC (Франция)

\section{Редакционный совет}

\section{Богомолова}

Татьяна Юрьевна

Веселов

Юрий Васильевич

Волков

Вадим Викторович

Гимпельсон

Владимир Ефимович

Лапин

Николай Иванович

Малева

Татьяна Михайловна

Овчарова

Лилия Николаевна

Радаев

Вадим Валерьевич

(главный редактор)

Хахулина

Людмила Александровна

Чепуренко Александр Юльевич

Шанин Теодор

Шкаратан Овсей Ирмович
Институт экономики и организации промышленного производства СО РАН (Россия)

Санкт-Петербургский государственный университет (Россия)

Европейский университет

в Санкт-Петербурге (Россия)

НИУ ВШЭ (Россия)

Институт философии РАН (Россия)

Институт социального анализа и прогнозирования РАНХиГС (Россия)

НИУ ВШЭ (Россия)

НИУ ВШЭ (Россия)

Аналитический центр Юрия Левады

(Россия)

НИУ ВШЭ (Россия)

Московская Высшая школа социальных и экономических наук (Россия)

НИУ ВШЭ (Россия) 
Journal of

Economic Sociology

Vol. 17. No 4.

September 2016

Electronic journal

www.ecsoc.msses.ru

www.ecsoc.hse.ru

\section{ISSN 1726-3247}

Journal of Economic

Sociology is a bimonthly

journal released in five

issues in annual volume.

No. 1 - January

No. 2 - March

No. 3 - May

No. 4 - September

No. 5 - November

\section{Establishers}

- National Research University Higher

School of Economics

- Vadim Radaev

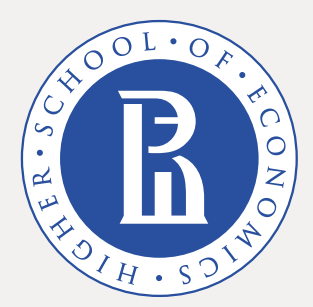

NATIONAL RESEARCH UNIVERSITY

\section{Editors}

Editor-in-Chief:

Editor:

Design and Layout:

Proofreader:

Managing Editor:

Editorial Staff:

Vadim Radaev (HSE, Russia)

Tatyana Sokolova (HSE, Russia)

Maria Mishina (Russia)

Nadezda Andrianova (HSE, Russia)

Zoya Kotelnikova (HSE, Russia)

Elena Nazarbaeva (HSE, Russia)

Natalia Conroy (HSE, Russia)

\section{International Editorial Council}

Sarah Ashwin

Ted Gerber

Alya Guseva

Peter Lindner

Christopher Swader

Valery Yakubovich

Jane Zavisca

\section{Editorial Council}

Tatyana Bogomolova

\author{
Alexander Chepurenko \\ Vladimir Gimpelson \\ Lyudmila Khakhulina \\ Nikolay Lapin
}

Tatyana Maleva

Lilia Ovcharova

Vadim Radaev (Editor-in-Chief)

Theodor Shanin

Ovsey Shkaratan

Yuriy Veselov

Vadim Volkov
The London School of Economics and Political Science (UK)

University of Wisconsin-Madison (USA)

Boston University (USA)

Goethe University Frankfurt (Germany)

Lund University (Sweden)

ESSEC Business School (France)

The University of Arizona (USA)

Institute of Economics and Industrial

Engineering of the Siberian Branch of Russian Academy of Sciences (Russia)

HSE (Russia)

HSE (Russia)

Yuri Levada Analytical Center (Russia)

Institute of Philosophy of Russian Academy of Sciences (Russia)

Institute of Social Analysis and Forecasting, The Russian Presidential Academy

of National Economy and

Public Administration (Russia)

HSE (Russia)

HSE (Russia)

Moscow School of Social and Economic Sciences (Russia)

HSE (Russia)

Saint Petersburg State University (Russia)

European University at Saint Petersburg (Russia) 


\section{Содержание}

Вступительное слово главного редактора (B. В. Радаев)

9

\section{Тексты на русском языке}

\section{Новые тексты}

\section{Е. С. Бердыишева}

Дифференциация «привлекательности» правонарушений

в восприятии российских полицейских.

\section{Новые переводы}

М. де Ваан, Б. Ведреш, Д. Старк

Игры-события: топология креативности

\section{Расширение границ}

С. Боулз

Моральная экономика: почему хорошие стимулы не заменят хороших граждан 100

\section{Дебютные работы}

М. В. Чернышёва

Благотворительность малого и среднего бизнеса в малом городе: эмпирический анализ.

\section{Профессиональные обзоры}

\section{Р. И. Романова}

Успех фирмы: что это такое, от чего он зависит и как его измерить 164

\section{Новые книги}

\section{И. В. Павлюткин}

Политическая экономия академического обм(е)ана, или Как социологи становятся профессорами Рецензия на книгу: Соколов М., Губа К., Зименкова Т., Сафонова М., Чуйкина С. 2015. Как становятся профессорами: академические карьеры, рынки и власть в пяти странах. М.: Новое Литературное обозрение (серия «История науки»). 832 с.

\section{Конференции}

\section{Г. Е. Новиков}

Нужно ли заниматься крупными темами в социологии?

Семинар Лаборатории экономико-социологических исследований, 6 сентября 2016 г., Москва, Россия. 


\section{Тексты на английском языке}

\section{Interviews}

Interview with Gabriel Abend "The Moral Background Makes the Play of Life Possible" (interviewed by Elena Gudova). 


\section{Contents}

Editor's Foreword (Vadim Radaev)

9

\section{Texts in Russian}

\section{New Texts}

Elena Berdysheva

Varying Worth of Crimes in the Eyes of Policemen in Russia

\section{New Translations}

Mathijs de Vaan, Balazs Vedres, David Stark

Game Changer: The Topology of Creativity.....

\section{Beyond Borders}

\section{Samuel Bowles}

The Moral Economy: Why Good Incentives Are No Substitute for Good Citizens (excerpts).

\section{Debut Studies}

Marina Chernysheva

Charity of Small- \& Medium-Sized Businesses

in a Russian Small Town: An Empirical Analysis

\section{Professional Reviews}

Regina Romanova

Firm Performance: How to Define it, What Affects it and How to Deal with Measurement Challenges.

\section{New Books}

Ivan Pavlyutkin

Political Economy of Academic Exchange:

How Do Sociologists Become Professors?

Book Review: Sokolov M., Guba K., Zimenkova T.,

Safonova M., Tchuykina S. (2015) Becoming a Professor:

Academic Careers, Markets and Power in Five Countries,

Moscow: New Literary Observer, 832 p. 


\section{Conferences}

Gleb Novikov

Should Big Topics in Sociology be Studied?

Seminar of Laboratory for Studies in Economic Sociology,

September 6, 2016, Moscow, Russia

\section{Texts in English}

\section{Interviews}

Interview with Gabriel Abend "The Moral Background Makes the Play

of Life Possible" (interviewed by Elena Gudova). 


\section{VR ВСТУПИТЕЛЬНОЕ СЛОВО ГЛАВНОГО РЕДАКТОРА}

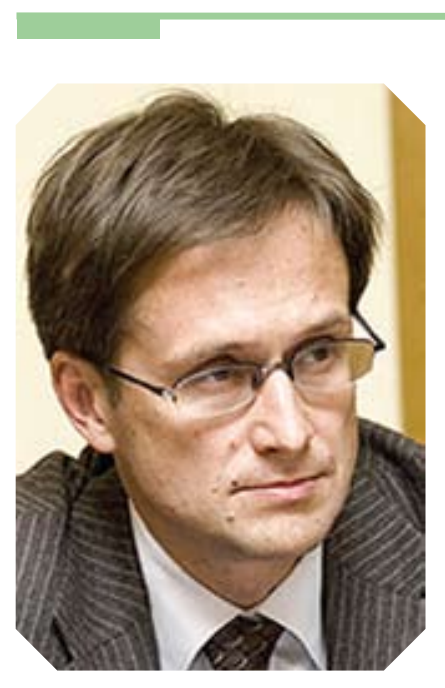

Уважаемые читатели, вновь у нас хорошие новости. В прошлом номере мы сообщили о том, что журнал «Экономическая социология» вошёл в Emerging Sources Citation Index (ESCI) в составе Core Collection - основного пакета баз на платформе WoS. Теперь мы рады сообщить о новом достижении: журнал принят для индексации в международную базу Scopus. Мы прошли через несколько раундов оценивания, вся процедура заняла более года и, наконец, минувшим летом была успешно завершена. Отныне журнал будет индексироваться в двух ведущих международных базах. Мы надеемся, что авторы и читатели журнала разделят нашу радость.

Теперь разрешите представить новый номер журнала.

В рубрике «Новые тексты» мы публикуем статью к. соц. н. E. C. Бердышевой (старший научный сотрудник ЛЭСИ НИУ ВШЭ) «Дифференциация “привлекательности” правонарушений в восприятии российских полицейских». Применяя подход институциональных логик для структурирования эмпирических данных, полученных в 2010-2016 гг. в ходе глубинных интервью с сотрудниками полиции, автор идентифицирует четыре институциональные логики - ведомственную, клановую, квазирыночную и профессиональную. Результаты исследования проливают свет на механизмы и обстоятельства принятия рабочих решений полицейскими, затрагивают вопросы неформальной экономической деятельности сотрудников полиции, а также помогают акцентировать дисфункциональные стороны реформы полиции в России.

Для рубрики «Новые переводы» мы подготовили статью Матейса де Ваана (доцент в области менеджмента организации Школы бизнеса им. Уолтера Хааса Университета Калифорнии в Бёркли), Балаша Ведреша (профессор факультета социологии и социальной антропологии, директор Центра по изучению сетей Центрально-Европейского университета) и Дэвида Старка (профессор социологии и международных отношений, декан факультета социологии Университета Колумбия) «Игры-события: топология креативности». Статья посвящена исследованию социологических факторов, объясняющих, почему творческим командам удаётся создавать игры-события - культурные продукты, которые стоят особняком не только как самобытные, но и как признанные критиками выдающимися. Авторы выстраивают свою работу на понятии «структурные складки» как сетевое свойство сплочённой группы, отдельные члены которой одновременно являются членами другой сплочённой группы. Гипотеза состояла в том, что эффект воздействия структурных складок на вероятность создания игры-события будет особенно сильным в том случае, когда пересекающиеся группы когнитивно разнородны. Авторы тестируют свои гипотезы о структурных складках и когнитивном разнообразии на основе анализа команд, собиравшихся для производства 12422 видеоигр, а также 139727 карьер разработчиков видеоигр. Перевод с английского сделал $A$. A. Куракин. Публикуется с разрешения издательства The University of Chicago Press.

Рубрика «Расширение границ» представлена первой главой из книги Самуэля Боулза (профессор, руководитель Программы в области поведенческих наук Института Санта-Фе, США) «Моральная экономика: почему хорошие стимулы не заменят хороших граждан» (М.: Изд-во Института Гайдара, 2016). В этой книге Боулз предлагает новую политическую парадигму, отказывающуюся от модели Ното economicus в пользу подхода к «людям как они есть». Автор уверен в том, что только те рыночные экономики, которые не отвергают своей культурной основы и людских добродетелей, способны работать хорошо. В публикуемой главе «Проблема с Ното есопотісиs» автор пытается убедить читателей в том, 
что экономическая модель человека не годится в качестве ориентира при разработке политического курса или организации бизнеса. Выстраивая свою аргументацию, автор обращается к широкому кругу философской, политической и экономической литературы. Перевод с английского Даниила Шестакова. Публикуется с разрешения издательства Института им. Е. Т. Гайдара.

В рубрике «Дебюты» публикуется статья М. В. Чернышёвой (аспирант департамента социологии факультета социальных наук НИУ ВШЭ) «Благотворительность малого и среднего бизнеса в малом городе: эмпирический анализ». Цель работы - выявление мотивов и барьеров участия малого и среднего бизнеса в благотворительности. Для объяснения используются критическая теория, теории солидарности, а также модели обмена привилегий на лояльность. Эмпирической базой исследования являются 21 полуструктурированное интервью с руководителями малого и среднего бизнеса и 13 интервью с руководителями некоммерческих, бюджетных организаций, с представителями власти, местными СМИ. Установлено, что наличие или отсутствие благотворительности бизнеса зависит от выстраивания баланса отношений между бизнесом, локальным сообществом и местными властями.

В рубрике «Профессиональные обзоры» размещена работа Р. И. Романовой (аспирант и преподаватель департамента социологии факультета социальных наук НИУ ВШЭ) «Успех фирмы: что это такое, от чего он зависит и как его измерить». Почему одни компании более успешны, нежели другие? Многочисленные исследования в стратегическом менеджменте, экономической теории и социологии пытаются ответить на данный вопрос. Их краткий обзор даётся в этой статье. Обуждаются методологические сложности изучения результативности компаний и необходимость создания композиционных моделей, которые учитывают синергетический эффект как внутренних, так и внешних факторов, вляющих на успех фирм.

В рубрике «Новые книги» к. соц. н. И. В. Павлюткин (доцент департамента социологии факультета социальных наук НИУ ВШЭ) предлагает рецензию на книгу М. Соколова, К. Губы, Т. Зименковой, M. Сафоновой, С. Чуйкиной «Как становятся профессорами: академические карьеры, рынки и власть в пяти странах» (М.: Новое Литературное обозрение, 2015). В рецензии дан краткий разбор отдельных глав книги, описаны безусловные достоинства монографии и условные её недостатки. В книге поднимается несколько важных тем, обсуждаемых сегодня в экономической социологии на разных эмпирических примерах: как взаимосвязаны мораль и рынки; как работают стимулы и как наблюдать их эффекты; являются ли институты заменителями доверия. Несмотря на провокационность отдельных тезисов, разоблачительность комментариев и дискуссионный характер авторских выводов, книга, безусловно, заслуживает внимания всех, кто так или иначе вовлечён в современную систему высшего образования и науки, - нынешних и будущих академиков, чиновников, управленцев и, конечно, тех, кто именует себя экспертами.

В рубрике «Конференции» Глеб Новиков (лаборант ЛЭСИ НИУ ВШЭ) рассказывает о первом в новом сезоне семинаре Лаборатории экономико-социологических исследований, прошедшем 6 сентября 2016 г. Открылся сезон моим докладом о проблеме связи отдельных эмпирических исследований с крупными темами в социологии. Было предложено искать темы, которые, не отрываясь от эмпирических наблюдений, связывают множество разнородных объектных сфер. В качестве примера такого подхода был продемонстрирован проект исследования, где значительное снижение объёма потребления алкоголя поколением Millennials рассматривается как индикатор более масштабных социальных сдвигов, свидетельствующих о возможном уходе «советского простого человека» с позиции доминирующего социального типа.

В разделе на английском языке, в рубрике «Интервью», доцент социологии Университета Нью-Йорка Габриэль Абенд рассказывает о своём интересе к социологии морали и об основных идеях книги 
«The Moral Background: An Inquiry into the History of Business Ethics» («Моральное основание: исследование истории деловой этики») (Princeton: Princeton University Press, 2014). Абенд утверждает, что изучение морали и морального действия в социальных науках происходит прежде всего на поведенческом уровне (моральное и аморальное поведение), а затем - на нормативном (нормы), всё вместе образует первый моральный порядок. Абенд также подчёркивает, что необходимо учитывать «моральное основание» (moral background), которое составляет третий уровень или второй порядок морали. Абенд выделяет два типа морального основания, названные им «Christian Merchant» («торговец-христианин») и «Standards of Practice» («стандарты практики»). Первый тип характеризует этику «бытия», развивающую определённые черты характера и моральный объективизм. Второй тип предполагает этику «действования», то есть моральный релятивизм и акцент на моральные действия; при этом игнорируются мотивы, лежащие в основе этих действий. Интервью провела Е. Гудова (ЛЭСИ НИУ ВШЭ).

С началом нового учебного года вновь стартует онлайн-курс «Экономическая социология» (лектор В. Радаев) на российской Национальной платформе открытого образования (НПОО). Записаться можно по адресу: https://openedu.ru/course/hse/ECSOC/

Там же найдёте проморолик.

А на глобальной платформе Coursera курс и не прекращался. Здесь применяется когортный подход на смену одной когорте слушателей приходит другая.

Запись на Coursera см.: https://www.coursera.org/learn/econom-sociology 


\section{VR INTRODUCTORY REMARKS}

\section{Dear colleagues,}

We have more wonderful news for you. The Journal of Economic Sociology has been accepted for indexation in Scopus. It took more than a year to get through several rounds of evaluation, but together with the ESCI in the Web of Science Core Collection, the journal has attained visibility in two major international citation indexes. We are proud of this achievement and would like to share this feeling with the journal's authors and readers.

Now we turn to the new issue of the journal.

We are publishing a new paper from Elena Berdysheva (senior research fellow, Laboratory for Studies in Economic Sociology, NRU HSE) entitled "Varying Worth of Crimes in the Eyes of Policemen in Russia." The paper demonstrates that crimes that come to the attention of the criminal police have varying worth in the eyes of Russian policemen and, consequently, attract unequal efforts. The worth of crimes is closely related to the criteria for evaluation of police performance. The data is derived from the series of in-depth interviews with Russian police officers, and the theoretical framework of data interpretation is represented by the symbiosis theories of valuations and an institutional logics approach. Four institutional logics - state, clan, quasi-market, and professional - are empirically identified. Each of them brings its own worth to police organizational environment. The results of the study shed light on the functioning of police discretion and help to accentuate the dysfunctional side of police reform in Russia.

In the section "New Translations," we present a paper by Mathijs de Vaan (assistant professor of management of organizations, Haas School of Business, University of California at Berkeley), Balazs Vedres (associate professor, Department of Sociology and Social Anthropology; Director, Center for Network Science, Central European University), and David Stark (Arthur Lehman professor of sociology, Department of Sociology; Director, Center on Organizational Innovation, Columbia University) called "Game Changer: The Topology of Creativity." The authors examine the sociological factors that explain why some creative teams are able to produce game changers - cultural products that stand out as distinctive while also being critically recognized as outstanding. The authors build on work pointing to structural folding — the network property of a cohesive group whose membership overlaps with that of another cohesive group. They hypothesize that the effects of structural folding on game changing success are especially strong when overlapping groups are cognitively distant. The authors test their hypothesis about structural folding and cognitive diversity by analyzing team reassembly for 12,422 video games and the career histories of 139,727 video game developers. The paper has been translated into Russian by Alexander Kurakin and is published with the permission of The University of Chicago Press.

In the section "Beyond the Borders," we offer the first chapter of Samuel Bowles' book (research professor, director of the Behavioral Sciences Program, Santa Fe, USA) entitled The Moral Economy: Why Good Incentives Are No Substitute for Good Citizens (New Heaven; London: Yale University Press, 2016). In this book, Bowles focuses on a new policy paradigm that proposes switching from Homo economicus to an approach that considers people as they are. The author argues that only market economies that do not ignore their cultural background and the goodness of people are able to work properly. In the translated chapter "The Problem with Homo Economicus," the author tries to convince readers that a Homo economicus approach is not a good baseline assumption for policy-making and business management. He addresses a wide array of philosophical, political, and economic literature to construct his arguments. The book has been translated by Daniel Shestakov and is published with the gracious permission of the Gaidar Institute Publishing House. 
Marina Chernysheva (doctoral student of the Department of Sociology, Higher School of Economics) presents a study entitled "Charity of Small- \& Medium-Sized Businesses in a Russian Small Town: An Empirical Analysis." This paper is aimed at revealing motivations and barriers for small- and medium-sized businesses to participate in charitable activities. Critical theory, theories of solidarity, and the model of patrimonial domination are applied as explanatory concepts. Twenty-one semi-structured interviews with the owners of smalland medium-sized businesses and 13 interviews with public officials were conducted. The author argues that charitable business results from balanced relationships between businesses, the local community, and local authorities.

Regina Romanova (doctoral student and lecturer at the Department of Sociology, Higher School of Economics) presents a paper titled "Firm Performance: How to Define it, What Affects it and How to Deal with Measurement Challenges" The author reviews numerous studies in strategic management, economic theory, and sociology that tackle that complicated issue. Methodological challenges in performance research are discussed. The study requires a combination of theoretical implications from divergent fields to build an adequate concept of the sources of performance variance.

In the section "New Books," Ivan Pavlyutkin (associate professor at the Department of Sociology, Higher School of Economics) offers his review on Becoming a Professor: Academic Careers, Markets and Power in Five Countries by Michael Sokolov, Katerina Guba, Tatyana Zimenkova, Maria Safonova, and Sofia Tchuykina (Moscow: New Literary Observer, 2015). The article briefly reviews the book's chapters, describes its explicit advantages, and examines its implicit disadvantages. The book addresses several important issues: morals and markets in academia; the impact and work of economic incentives; and the strengths and weaknesses of social networks, academic pathways, and political culture. Along with its provocative thesis, incriminating comments and polemic conclusions make this book worth reading for all those who are involved in the modern system of higher education and science - academics, civil servants, governors, and of course, various experts.

Gleb Novikov (junior research fellow, Laboratory for Studies in Economic Sociology, NRU HSE) reviews the first seminar of the Laboratory for Studies in Economic Sociology, which began on September 6, 2016. Laboratory Head Vadim Radaev was a speaker, and his presentation explored the links between concrete empirical studies and "broad topics" in sociology. Radaev suggested looking for topics that are not separated from empirical findings and connect many subject areas. A draft research project was considered as an illustrative example. The point was to relate a decrease in alcohol consumption by the Millennial generation to larger-scale social shifts and potentially to the withering away of a "Soviet common man" from the position of a dominant social type.

\section{Texts in English}

Associate Professor of Sociology Gabriel Abend from New York University was interviewed about his interest in the sociology of morality and the main ideas of his book The Moral Background: An Inquiry into the History of Business Ethics (2014). Abend states that studying moralities and moral action in the social sciences is usually viewed through the lenses of the behavioral level first and the normative level second (moral and immoral behavior and norms, respectively), which, taken together, constitute first-order morality. Abend also points out that a "moral background" should be the third level, or second-order morality. Abend identifies two types of moral background that he describes as the "Christian Merchant" and the "Standards of Practice." The "Christian Merchant" type can be characterized as an ethics of "being," developing certain features of character and moral objectivism. The "Standards of Practice" is an ethics of "doing" — moral relativism with an emphasis on moral actions and no particular attention to their motives. The interview was recorded by Elena Gudova (NRU HSE). 
A massive open online course entitled "Economic Sociology" (in Russian) is beginning at the Russian National Platform of Open Education with Vadim Radaev as lecturer. You can see a promo video and enroll for the course at: https://openedu.ru/course/hse/ECSOC/

This lecture course is available online on the global platform Coursera. A cohort approach is being used, where one cohort of students come to replace the previous one.

You can enroll for this course at Coursera: https:/www.coursera.org/learn/econom-sociology 


\section{НОВЫЕ ТЕКСТЫ}

\section{Е. С. Бердышева \\ Диффреренциация «привлекательности» правонарушений в восприятии российских полицейских ${ }^{1}$}

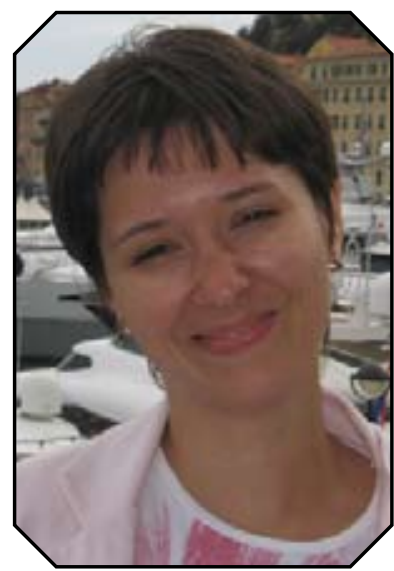

\section{БЕРДЫШЕВА Елена}

Сергеевна - кандидат социологических наук, старший преподаватель департамента социологии, старший научный сотрудник Лаборатории экономикосоциологических исследований Национального исследовательского университета «Высшая школа экономики». Адрес: 101000, Россия, г. Москва, ул. Мясницкая, д. 20.

Email: eberdysheva@ hse.ru
Работа полицейских над тем или иным правонарушением направляется представлениями о критериях оченивания эффективности их деятельности (police performance). Различные дела, поступившие в разработку, имеют в глазах полицейских неодинаковую ценность и обрабатываются с разным рвением.

Подход институцииональных логик связывает порядки обоснования иченности с интересами, верованиями, миссией институциональных акторов, а также с той культурно-материальной средой, в которой они действуют. Применение этого подхода для структурирования эмпирических данных, полученных в 2010-2016 г2. в ходе глубинных интервью с сотрудниками полиции, выпускниками Московского университета Министерства внутренних дел Российской Федераџии имени В. Я. Кикотя (МосУ МВД России имени В. Я. Кикотя), проходящими трудовую практику в полицейских подразделениях, а также в ходе анализа дискуссий в интернет-сообществе российских полицейских, позволяет идентифицировать четыре институциональные логики: ведомственную, клановую, квазирыночную и профессиональную. Именно они задают критерии оценки иенности, на которые в разных ситуачиях ориентируются полицейские. Демонстрируется, что работа над правонарушением в глазах поличейских имеет иену, выраженную либо «в палках», либо в признании со стороны начальника или коллег, либо в форме изменения профессиональной самооценки и репутации, либо в деньгах. При этом данные позволяют говорить о том, что, хотя на уровне правоохранительной системы в целом между институциональными логиками существует определённая иерархия, в каждом конкретном случае порядки обоснования иенности конкурируют друг с другом, и в зависимости от обстоятельств «дела» проблема множественности логик оченивания может решаться полицейскими по-разному. Результаты исследования проливают свет на механизмы и обстоятельства принятия рабочих решений полицейскими, затрагивают вопросы неформальной экономической деятельности сотрудников полиции, а также помогают акцентировать дисфункциональные стороны реформы полиции в России.

В данной научной работе использованы результаты проекта «Неформальная экономическая деятельность полиции в трансформирующихся странах и проблемы безопасности населения (на примере России, Болгарии, Казахстана и Латвии)», выполняемого в рамках Программы фундаментальных исследований НИУ ВШЭ в 2016 г.

Автор признателен профессору Л. Я. Косалсу, а также анонимным рецензентам за комментарии и замечания, позволившие существенно повысить качество статьи. 
Ключевые слова: порядки обоснования ценности; справедливость; профессионализм; коррупция; реформа полиции в России; эффективность деятельности полиции.

\section{Введение}

Проблематика оценивания (evaluation) занимает сегодня одно из центральных мест в ряду вопросов, интересующих новую экономическую социологию [Hutter, Stark 2015: 2]. В 2013 г. учреждён специализированный журнал «Valuation Studies», в консультационный совет которого вошли такие ключевые для новой экономической социологии фигуры, как, например, М. Каллон, М. Ламон, Д. Старк, Б. Чернявска, М. Фуркад и др.; рецензируемый, открытый и междисциплинарный².

В современном мире сложно найти сферу, где оценивание отсутствует [Helgesson, Muniesa 2013: 3]. Соизмерение (commensuration) и калькуляция являются важным способом координации человеческих действий, и это не нейтральный, но политический процесс [Espeland, Stevens 1998]. Стремление современного информационного общества к постоянному наращиванию эффективности процессов, его очарованность аудитом и инновациями подогревают интерес к проблемам соизмерения, калькуляции, социального конструирования ценности (worth). Однако не только инновации нуждаются в том, чтобы параметры их ценности рефлексировались социальными акторами [Hutter, Stark 2015]. Калькуляция позволяет конструировать отношения авторитета, создаёт политические единицы, устанавливает новые интерпретативные рамки. Оценивание и калькуляция - фундамент для менеджмента (не важно, об управлении каким типом организации идёт речь). Логика эффективности сегодня распространяется широко за пределы бизнес-сферы, проникает в общественные, некоммерческие организации, попутно меняя их лицо.

В данной статье речь пойдёт о полиции. Дебаты по поводу того, при помощи каких критериев лучше оценивать продуктивность, эффективность, ценность деятельности (performance) этой организации, насчитывают несколько десятилетий. И это неудивительно: система оценки сигнализирует о миссии, целях и стандартах деятельности организации, напрямую влияет на мотивацию сотрудников, детерминирует линии поведения, которые считаются желательными [Maguire, Wells 2009]. В случае с opганизацией, которой в обществе делегировано право на легитимное насилие в целях поддержания действующего правового порядка, трансляция ожиданий по поводу поведения сотрудников имеет первостепенное значение для сохранности и безопасности. Удивление вызывает другое: почему среди множества исследований подходов к оценке эффективности деятельности полиции (police performance) так мало внимания уделяется вопросу о том, какими логиками оценивания руководствуются сами полицейские, и тому, как логики, привносимые внешним оцениванием, и логики, функционирующие внутри полицейской организации, соотносятся друг с другом при принятии ими повседневных профессиональных решений. Например, при принятии решений о том, регистрировать ли происшествие, о котором пытаются заявить, или нет, а если регистрировать, то разбираться ли с ним по протоколу или, возможно, использовать его как источник дополнительной денежной прибыли. Когда с рядовым гражданином случается что-то, нуждающееся, по его мнению, в участии сотрудников полиции, исходно предполагается, что необходимый объём усилий полицейских гарантирован их должностными обязанностями. Однако это не так. Происшествия и преступления имеют в глазах полицейских неодинаковую ценность.

За оценкой ценности (worth) любого феномена, в том числе и проблемы, над решением которой трудятся правоохранительные органы, всегда скрываются ценности (values), значимые для оценивающих

2 Веб-сайт журнала: URL: http://valuationstudies.liu.se/ 
акторов [Stark 2011], потому изучение принципов, которыми полицейские руководствуются, принимая решения о том, что делать с поступившим в их ведение «делом», может пролить свет на устройство полицейской организации и на ценности, которыми она живёт. Российской полиции, которую на протяжении трёх постсоветских десятилетий постоянно уличают в неэффективности, а начиная с 2010 г. непрерывно реформируют, в том числе в части системы оценки police performance, подобные исследовательские инсайты могут сослужить не только теоретическую, но и практическую службу.

Теоретические основы данного исследования заданы теориями оценивания в совокупности с подходом институциональных логик, обеспечивающим аналитический каркас в организационном анализе. А он предполагает, что практические решения принимаются акторами в условиях балансирования между различными институциональными логиками, под которыми подразумевается совокупность культурных правил и ожиданий, задающих легитимные основания оценивания и определяющих, что именно в данном контексте является рациональным поведением [Thornton, Ocasio, Lounsbury 2012]. Прояснение конфигураций институциональных логик помогает установить те дилеммы, которые имеются в сознании и нормах поведения полицейских, и описать двойственные, как предполагается в данной работе, условия, в которых сотрудники полиции находятся.

Подход институциональных логик акцентирует конкуренцию ценностей, на стыке которых приходится действовать российским полицейским, указывает как на историческое доминирование ведомственной и клановой логик организации полицейской системы в России, так и на функциональные эффекты прибылеориентированной квазирыночной логики, а также открывает возможность коррекции дисфункций правоохранительной системы путем намеренного усиления профессиональной логики в деятельности полицейских.

Цель работы: выявление логик, в координатах которых российские полицейские принимают практические решения о необходимом объёме усилий, направляемых на работу над тем или иным происшествием, попадающим в поле их профессионального зрения.

Данная статья подготовлена в рамках исследовательского проекта «Неформальная экономическая деятельность полиции в трансформирующихся странах и проблемы безопасности населения (на примере России, Болгарии, Казахстана и Латвии)», реализуемого НИУ ВШЭ с 2012 г. по настоящее время. Первоначально сбор эмпирических данных был направлен на зондирование широкого круга вопросов, релевантных базовой тематике, и особенно на выявление болезненных точек в организации деятельности российских полицейских, создающих предпосылки для её коммерциализации. Одной из центральных тем в проанализированных нарративах и дискурсах российских полицейских оказались многочисленные и многообразные эффекты систем оценки результативности их деятельности. Это стало стимулом обратиться к концептуальным ресурсам теорий оценивания (valuation studies) и выделить с их помощью анализ данного конкретного аспекта комплексной деятельности российских полицейских в отдельную исследовательскую задачу. Подход институциональных логик обеспечил возможность структурирования полученных данных, направил анализ в сторону поиска в полицейской организации замкнутых систем оценивания, конкурирующих друг с другом. Содержательное наполнение этих логик стало возможным благодаря серии из 12 глубинных интервью с сотрудниками полиции г. Москвы, полученных в 2010-2016 гг. (см. приложение). Выборка исследования была целевой.

За период выполнения данной работы закрытость полицейской организации для исследования существенно возросла. Для мониторинга текущей ситуации по изучаемому вопросу были поэтому привлечены данные девяти интервью с курсантами последнего курса Московского университета МВД России им. В. Я. Кикотя, которые на момент проведения интервью проходили трудовую практику в различных 
ОВД г. Москвы и принимали участие в исследовании «Полиция как профессия: карьерные ожидания студентов Академии МВД» .

Все интервью были подвергнуты категориальному анализу.

Кроме того, содержание искомых институциональных логик уточнялось и детализировалось с помощью данных онлайн-дискуссий, разворачивающихся на интернет-форуме сотрудников МВД РФ в 2010-2016 гг. С учётом того, что при регистрации на форуме администраторы требуют от потенциальных участников документы об их профессиональной принадлежности, то есть известно, какие из высказываний принадлежат сотрудникам полиции, действующим или в отставке, использование данного ресурса для анализа ситуации в труднодостижимом для социологов профессиональном сообществе видится оправданным, особенно при разведывательном характере описываемого в данной статье исследования.

Опишем структуру рассуждений в статье. Прежде всего, даётся краткая характеристика теоретикометодологических и эмпирических оснований исследования.

Далее последовательно раскрываются четыре институциональные логики - государственная, клановая, квазирыночная и профессиональная, - реконструированные по итогам анализа нарративов полицейских. Акцент делается на том, какие порядки оценивания «привлекательности» правонарушений, поступивших в разработку, предлагает сотрудникам полиции каждая из логик. За описанием четырёх логик следует попытка оценить соприкосновение и трение между ними, задающие возможные развилки выборов при принятии полицейскими практических решений по происшествиям и преступлениям.

В заключении статьи выводы исследования осмысляются в свете современных научных дискуссий о полицейских дисфункциях и возможных направлениях их преодоления через реформирование правоохранительной системы.

\section{Локус интерпретации данных: между теориями оценивания и подходом институциональных логик}

Первоначально оценивание всегда направлено на преодоление неопределённости, возникающей в связи с трудностями вынесения суждений по поводу того, что именно в той или иной ситуации составляет ценность [Aspers, Beckert 2011: 5]. Эти трудности, в свою очередь, являются результатом множественности шкал, при помощи которых может быть измерена ценность, обоснован вердикт по поводу того, что хорошо, а что плохо, что допустимо, а что нет.

Между разными шкалами определения ценности могут существовать компромиссы, они совместимы до определённых пределов, границы между ними бывают очень тонкими, а трения ведут как к противоречиям и конфликтам, так и к новым решениям старых проблем.

Порядки обоснования ценности необязательно строго соизмеримы (commensurable) между собой, но при этом за любым из них всегда скрыто особое представление о рациональности. Каждая из множественных шкал измерения ценности обеспечивает свою возможность для калькуля-

3 Автор благодарит выпускницу бакалавриата департамента социальных наук НИУ ВШЭ 3. Е. Пчельникову за предоставленную возможность использовать транскрипты интервью, полученных ею в ходе написания выпускной квалификационной работы.

4

URL: https://police-russia.com/ 
ции [Stark 2011: 321]. Основной задачей исследователя в таком свете оказывается необходимость реконструировать «инфраструктуру калькуляции» [Heuts, Mol 2013].

Подобный вектор рассуждений не является открытием для социологической теории. П. Бергер и П. Лукман говорили о том, что в обществе существуют сформированные по различным критериям изолированные смысловые подуниверсумы, придающие объективный смысл различным видам человеческой деятельности, общность которых поддерживается группами, непрерывно создающими рассматриваемые значения и воспринимающими их как часть объективной реальности [Бергер, Лукман 1995]. Социальный порядок неоднороден, он сегментирован, и вопрос лишь в том, каким образом стабилизированы критерии определения ценности, где скрыты их источники.

Для одних авторов такими источниками представляются социальные институты. Рынок, государство, профессии, религия, семья и проч. задают различные способы оценивания тех или иных объектов и действий [Friedland, Alford 1991; Greenwood, Hinings 1993]. В пределах каждого из этих институтов существуют свои представления о том, какие критерии обоснования и оценивания ценности легитимны.

Другие авторы не связывают содержание интерпретативных схем напрямую с социальными институтами, а выделяют замкнутые сферы («миры»), привносящие те или иные критерии оценки. Так, например, авторы теории конвенций (с которой плотно работают апологеты теорий оценивания) Люк Болтански и Лоран Тевено говорят о том, что восприятие ситуаций и поведение людей в них во многом зависят от существующих в обществе моральных порядков и локальных способов оценивания, которые воплощены в объектах, признанных в различных режимах прагматичной вовлечённости в мир [Болтански, Тевено 2000: 85-86; Тевено 2000].

Некоторые авторы не соглашаются с идеей о бытовании неких стабильных самодостаточных «миров» с соответствующей им логикой интерпретации и обоснования ценности, а настаивают на существовании модальностей, регистров, режимов ценности, актуализируемых под влиянием исторических, культурных и социальных факторов в той или иной ситуации. В определённое время и в определённом месте может актуализироваться та или иная модальность оценивания. Какая именно - зависит от обстоятельств обмена, а не от сферы обмена или пространства калькуляции [Appadurai 1995]. В свете такого подхода оценивание оказывается результатом комплексной системы взаимодействий и обменов между людьми и вещами. При этом наряду с множеством модальностей измерения ценности существуют локальные практики, в ходе которых творческие, калькулирующие индивиды создают асимметрии и пользуются ими [Appadurai 1995]. Эта идея активно развивается Дэвидом Старком, настаивающим на том, что очень часто критерии значимости реконструируются, осознаются акторами непосредственно в ходе взвешивания альтернатив. В таком случае принципиально важным оказывается методологический поворот от изучения ценности как свойства (worth) к изучению оценивания (evaluation) как социальной деятельности [Heuts, Mol 2013: 5]. Предполагается: фокусируясь на том, как акторы осуществляют оценивание, исследователь получает возможность заметить, что в ходе этого процесса находится на кону (at stake) [Mennicken, Sjögren 2015]. Для самих оценивающих акторов этот когнитивный пласт может оставаться латентным, сведённым к практическим заботам о том, чтобы действия вели «к лучшему». Акт заботы и есть способ реализации оценивания. Для заинтересованного стороннего наблюдателя и заботы акторов, и столкновение принципов оценивания могут служить ключом к властной укоренённости и политической подоплёке калькулятивного процесса [Mennicken, Sjögren 2015].

Оценивание может принимать самые разные формы: «за всё в этой жизни нужно платить, но необязательно плата будет выражена в деньгах». Так, прагматизм Д. Дьюи помогает Д. Старку показать, что 
результаты оценивания могут объективироваться через раздачу наград (prize) и оценок (appraisals), похвал (praise) и денежных цен (price) [Stark 2011]. Процедуры оценивания перформативны, и в этом скрыт ещё один путь конструирования ценности в обществе. Использование модели улучшает её предсказательные способности; при этом предсказательные способности модели и являются индикатором её качества, ценности [Stark 2011].

С вопросом об источнике разных принципов оценки ценности тесно связана проблема количества ценностных порядков, актуальных в тех или иных социальных обстоятельствах. Если ценностные регистры диктуются ситуацией, то их число ничем не ограничено. При этом избыточность, являясь источником дополнительной неопределённости, порождает, как считает тот же Старк, и новые возможности [Старк 2009]. В целом ряде случаев, полагает Старк, проблемой является не существование нескольких принципов оценивания, но, напротив, их дефицит [Старк 2009]. Устойчивость классификационных порядков может мешать адаптации к ситуации, снижать способности реагировать на изменчивость среды.

Однако всё-таки сам акт оценивания нацелен на снижение неопределённости, на стабилизацию порядка. Для реализации действия - того же обмена — важно, чтобы действующие имели схожие представления (shared understanding) о том, что в подобной ситуации может представлять ценность [Aspers, Beckert 2011: 14]. И тогда ничем не ограниченная пролиферация принципов оценивания фактически ведёт к абсолютной сингуляризации оцениваемого объекта, тем самым подводя оценивание к черте, за которой калькуляция перестаёт быть возможной [Mennicken, Sjögren 2015: 4].

Методологический выбор на данной развилке должен осуществляться в зависимости от того, в каких организационных контекстах планируется изучать акты оценивания и инфраструктуру калькуляции. Идея Старка о продуктивности неопределённости, возникающей на стыке различных принципов оценивания, всё-таки неотделима от его мысли о гетерархичности некоторых организаций как свойства, рождающегося в ответ на повышенную непредсказуемость среды. Гетерархия - антитеза новому институционализму в организационном анализе, где организация находится в относительно стабильной среде, потому и набор критериев классификации, принципов оценивания, которые в ней применяются, достаточно устойчив. Институциональный подход не исключает возможности появления новых критериев оценивания как в организационном поле, так и внутри организации, но всё же эти преобразования неконтингентны.

Старк выстраивает свою организационную концепцию, развивая идеи теории конвенций, которая предполагает, что у спорящих акторов, в том числе и находящихся внутри комплексно устроенной организации, всегда есть возможность прийти к компромиссу, опереться на принципы эквивалентности, найти точки пересечения мнений. И вместе с тем Старк не соглашается с этой теорией в центральном вопросе, настаивая на том, что целью переговоров необязательно является достижение согласия и в каждой конкретной ситуации обоснование ценности всегда должно осуществляться в пространстве нескольких порядков оценивания [Stark 2009]. В это же время теория конвенций, как отмечалось выше, связывает происхождение ценностей с отдельными смысловыми универсумами, жизненными мирами: ценности каждого из миров видятся значимыми для каждого из спорщиков. Однако в применении к исследованию организаций эта идея размывается, и, как известно из хрестоматийного примера о споре между бухгалтерией и отделом маркетинга, акторы в переговорах всё-таки первоначально опираются на определённую иерархию ценностных порядков. Причём эта иерархия диктуется особенностью их положения в организации, миссией и задачами, за которые они несут ответственность. В связи с этим более продуктивным для изучения множественности ценностных порядков внутри организации представляется подход институциональных логик. Он изначально акцентирует конкурентные отношения между различными принципами оценивания и допускает возможность баланса порядков оценивания 
за счёт фактора власти, обеспечивающего временное доминирование одной из систем обоснования ценности. Именно подход институциональных логик используется в данной работе для реконструкции принципов практической классификации происшествий в глазах сотрудников российской полиции.

Подход институциональных логик берёт своё начало в работе Роджера Фридланда и Роберта Элфорда «Возвращая общество: символы, практики и институциональные противоречия» (1991 г.), опубликованной в сборнике «Новый институционализм в организационном анализе» под редакцией Уолтера Пауэлла и Пола Димаджио (см.: [Friedland, Alford 1991]). Сборник посвящён организационному анализу, а исходный запрос на подход институциональных логик возникает у авторов в связи с анализом радикально настроенных религий и поиском ключевой институциональной логики, которая могла бы, в духе идеи М. Вебера о протестансткой этике и духе капитализма, объяснить происходящее в европейском обществе в XX веке [Friedland 2012]. Однако, как только эти идеи подхватываются организационным анализом, предположение о существовании единой институциональной логики, способной объяснить происходящие в организации практики, подвергается критике. Основное условие, в котором действуют современные организации, тяготеет к тому, что называется институциональной комплексностью (организационной комплексностью в версии Болтански и Тевено), то есть к сосуществованию различных институциональных логик и способов балансирования акторов между ними. В то же время на уровне эмпирических исследований пока больше внимания уделялось динамике институциональных логик в различных сферах, и чаще всего - переходу от профессиональных оснований деятельности к менеджериально-рыночным, нежели тому, как различные логики, во-первых, операционализируются на практике, а во-вторых, могут соотноситься между собой [Friedland 2012].

Современные организации функционируют в условиях институциональной комплексности. Их деятельность многомерна и требует привлечения различных институциональных акторов, которые, в свою очередь, привносят собственные институциональные логики. При этом если одни исследователи считают, что успех организации связан с выстраиванием компромиссов между сосуществующими здесь институциональными логиками [Болтански, Тевено 2000], то другие настаивают на том, что институциональные логики всегда находятся в конкуренции друг с другом и баланс возникает на этапах, когда одна из логик временно становится доминирующей и некоторое время преобладает в организации, тем самым укрепляя её целостное представление о собственной миссии на внешнем и внутреннем планах [Скотт 2007]. Институциональные логики, таким образом, описывают особые констелляции правил, ролей, интерпретаций и практик, обретающих легитимность за счёт направленности деятельности на поддержание порождающих их ценностей [Friedland 2012: 585]. Интересы различных типов акторов в таком свете оказывается невозможно постичь без понимания того, как эти акторы трактуют ситуацию.

Развитые в организации системы оценивания связывают содержание институциональных логик с системами управления, указывая определённым акторам на последствия выбора тех или иных линий поведения в тех или иных обстоятельствах. Система оценки деятельности любой организации задаёт трактовки её целей, миссии, принципов и стандартов деятельности. В идеале система оценки деятельности представляет собой систему сигналов для сотрудников, транслирующих ценности организации и ожидания по отношению к её представителям.

Таким образом, при описании различных институциональных логик принципиально важным представляется обращать внимание на следующие элементы:

— на реализацию какой функции ориентированы институциональная логика и связанные с ней критерии оценивания? На решение какой содержательной задачи эта логика ориентирована, и каковы системы убеждений, которые из неё вытекают? 
- кто из институциональных акторов организационного поля является проводником данной логики, и каковы его позиции во властной структуре данного поля?

- какие институциональные инструменты, связанные с логикой критериев оценивания, закреплены в организационном поле? Каковы транслируемые ими правила, и какими санкциями они поддерживаются?

Поиск ответов на поставленные вопросы позволяет выявить заданные различными институциональными логиками режимы оценивания и тем самым приблизиться к пониманию критериев, при помощи которых «привлекательность» происшествия определяется полицейскими в России.

\section{Четыре логики принятия решений полицией: эмпирические результаты исследования}

В разрозненном виде установки, диктуемые российским полицейским отдельными ценностными системами, проблематизировались в литературе (см., например: [Панеях, Титаев 2011; Гладарев 2012; Бердышева 2013]). В данном разделе предпринимается попытка целостно описать топологию институциональных логик, актуальную сегодня для сотрудников российской полиции, и от констатации множественности значимых ценностных систем перейти к анализу их соотнесённости друг с другом. Сама топология при этом возникает на стыке теории и эмпирики.

\section{Ведомственная институциональная логика: «государева служба»}

Ведомственная логика отсылает нас к государствообразующей функции института полиции как органа, которому, с одной стороны, делегировано право на применение легитимного насилия с целью поддержания господствующего политического порядка, а с другой - вменены обязательства по обеспечению безопасности населения, без которой невозможна легитимность действующей власти. Достижения в этой логике фиксируются при помощи формальных оценок сотрудников в соответствии с системами государственной оценки их деятельности, а также в форме, выраженной в деньгах официальной заработной платы, начисляемой с учётом качества достигнутых формальных показателей.

По мере развития обществ и накопления ими «юридического капитала» системообразующая потребность в полиции как органе реализации насилия снижается [Бурдьё 2005]. Тем не менее в современном обществе именно полиции вверяется функция реализации социального контроля. Существуют два подхода к определению принципов деятельности полиции. Первый предполагает, что полиция является карательным органом, представляющим государство (punitive approach). Второй подход концептуализирует полицию как общественный орган, служащий интересам общества. Несмотря на то что в первом случае интересы общества также формально приоритетны в рейтинге целей полиции, содержательно и практически он разительно отличается от ситуации, когда полиция существует «для людей» (police for people).

История российской полиции восходит к Разбойным приказам XVI-XVII веков - органам управления, функция которых, как известно, состояла в борьбе с разбоями. Далее, как следует из исторических источников, все реформы полиции последовательно вели её к централизации и подчинённости задаче защиты создаваемого государственного порядка (см.: [Малыгин 2001; Уваров 2013]). Список функций, записанных за правоохранительными органами, очень разветвлён. В качестве основных оцениваемых направлений деятельности полиции выделяются следующие: регистрация, учёт и разрешение заявлений, сообщений и иной информации о происшествиях; профилактическая деятельность; выявление преступлений; раскрытие преступлений; розыск лиц; предварительное следствие; дознание; обеспече- 
ние общественного порядка, общественной безопасности и безопасности дорожного движения; оказание государственных услуг населению. И тем не менее оценки эффективности деятельности этой профессиональной группы выстраиваются в первую очередь по критерию борьбы с преступностью. Скорее всего, потому, что рост уровня преступности наносит урон легитимности действующей государственной власти.

Требования и ожидания государства в отношении правоохранительных органов закапсулированы в формальной системе оценки эффективности их работы, встроенной в полицейскую практику.

Поиском оптимальной системы измерения и оценки деятельности правоохранительных органов российская система МВД активно занимается на протяжении последних 35-40 лет [Бунов 2011]. И, несмотря на то что одним из ключевых направлений реформирования полиции в 2010-е гг. был пересмотр системы оценки эффективности её деятельности, основой для оценки деятельности полиции по-прежнему остаётся формируемая самой полицией статистическая отчётность, отражающая главным образом уровни преступности и раскрытия преступлений.

Базовым инструментом формирования полицейской отчётности и, что более важно, внутренней оценки эффективности деятельности сотрудников полиции является система АППГ +1 , где АППГ - аналогичный период прошлого года, а «+ 1» означает, что динамика - положительная или отрицательная - показателей по каждому из направлений по сравнению с аналогичным периодом прошлого года составляет основу для выводов об эффективности деятельности. По части показателей системой ожидается положительная динамика, по части - отрицательная или нулевая в зависимости от того, о каких показателях идёт речь. При любой динамике сотрудникам приходится помнить, что оцениваемые относительно прошлого периода показатели текущего года становятся, в свою очередь, основой для построения оценок в будущем. В повседневной деятельности полицейских система АППГ +1 носит неформальное название «палочная» (чёрточки за законченные дела в бланках текущей отчётности). Долгое время основным интегративным отчётным показателем в рамках палочной системы был процент раскрываемости преступлений. Особый приказ № 25 по реорганизации милиции в полицию, принятый в 2011 г., ввёл в оборот такой показатель качества работы полицейских, как выполнение прогнозов. В новой системе окончательно была оформлена идея о том, что показатели работы со временем должны постоянно улучшаться. При этом, с учётом того, что в обязанности полицейских входят ещё такие задачи, как профилактика и предотвращение преступлений, темпы этих улучшений весьма велики, ведь число раскрытий должно постоянно повышаться на фоне параллельного (опять же постоянного при условии качественной профилактики и предотвращений) сокращения числа случившихся преступлений.

Взятый ещё советской милицией курс на приоритет количественных показателей по отношению к качеству сохраняется до сих пор. Сотрудники настаивают на том, что на практике существенных изменений по этому направлению не происходит:

Общался со многими ребятами; все одно говорят: палки, палки, палки!!!!!! Не знаю, у кого как по службам, раньше помню с УУМ (Участкового уполномоченного милиции. - Е. Б.) требовали пять протоколов по АП (Административному правонарушению. - Е. Б.) в месяи, сейчас с них (по крайней мере, у нас) требуют по одному в день, то есть порядка 30 в месяи (интервью, Вадим, отдел МВД, 2015 г.).

Основная версия, объясняющая устойчивость существующей системы оценивания, сводится к тому, что она является проблематичной на уровне операционной, практической деятельности полицейских, но при этом вполне успешно обслуживает потребность в вертикальном управлении централизованной полицейской организацией: 
Планы адмпрактики (Административной практики. - Е. Б.) идут от начальства. Министр в конце года спросит со своих генералов результаты работы. И чтобы не получить за что-нибудь, они постараются, чтобы был плюсовой показатель (интервью, Дмитрий, майор, 2015 г.);

Моё мнение: планы и палки — атавизм коммунистического прошлого, суть которого: мне наплевать, как ты работаешь, мне нужен механизм манипуляции, чтобы ты на призыв «Надо!», не раздумывая, всегда отвечал: «Есть!» (из дискуссии на онлайн-форуме сотрудников МВД РФ, 2016 г.).

Система АППГ + 1 призвана измерять эффективность деятельности полиции на разных уровнях отдельного сотрудника, отдела, отделения и т. д. Движение между макроуровнями и микроуровнями осуществляется коррекцией плана работ на численность подразделения. Данные статистической отчётности составляют основу для поощрения и наказания сотрудников. При этом и пряники, и хлысты реализуются через механизм заработной платы, которая, как и во многих других государственных учреждениях, имеет разветвлённую структуру. Выплата служащим в рядах органов внутренних дел сейчас регулируется согласно приказу МВД РФ № 65 «Об утверждении порядка обеспечения денежным довольствием сотрудников органов внутренних дел Российской Федерации» от 31 января 2013 г. $^{5}$

Заработная плата сотрудника полиции состоит из должностной ставки и оклада за звание. Размер должностной ставки зависит как от занимаемой должности, так и от месторасположения полицейского участка и нагрузки на него. Служба в Москве, Санкт-Петербурге, Московской и Ленинградской областях предполагает увеличение оклада на 10\%. Блюстители правопорядка также получают надбавку за выслугу лет: 10-40\% к должностному окладу в зависимости от срока службы.

Надбавки за квалификационное звание (специалист первого, второго, третьего класса), особые условия службы, за работу с информацией, представляющую государственную тайну, также увеличивают уровень официальной заработной платы. Более того, в состав заработной платы работника МВД входят премии и различные поощрительные выплаты, то есть выплаты за особые достижения по службе; а также премирование за добросовестное выполнение должностных обязанностей.

Премирование за добросовестное выполнение должностных обязанностей начисляется из расчёта три оклада денежного содержания в календарный год. Эта сумма выплачивается служащим дозированно, каждый месяц из расчёта 25\% от суммы зарплаты, установленной сотруднику по состоянию на 1-е число того месяца, за который делается выплата.

Выплата или невыплата тех или иных составляющих заработной платы полицейского зависит от показателей, фиксирующих качество его работы Дополнительные выплаты и должностные оклады служащим органов внутренних дел назначаются, а также изменяются приказом руководителей соответствующих подразделений.

Цели, заданные ведомственной институциональной логикой, сказываются на восприятии ценности различных происшествий российскими полицейскими за счёт того, что палочная система контролирует структуру и темпы работы над правонарушениями:

Тем, кто работает на линии, нужно принести определённое количество протоколов, и если их не принесут, то будет не очень хорошо. Я присутствовал на одном из «разводов», то есть

5 См. подробнее: URL: http://base.garant.ru/70375922/\#ixzz4H69jle9A 
на встрече, где тебе дают задание, типа: ребята, вы должны принести каждый там по три протокола с участием моточиклистов, на что, собственно говоря, [последовал] вопрос из зала одного из сотрудников: «А как же мы их принесём, мы их остановить не можем», - на что был дан ответ, типа: «Ребята, а палка вам на что?» (интервью, Вадим, отдел МВД, 2011 г.).

В зависимости от социополитической ситуации в стране акцентируется интенсивность работы полиции над теми или иными преступлениями:

Ценность разных статей уголовных дел различна. Если в этом году требуется бороться с определёнными преступлениями руководством МВД, то эти статьи имеют больший вес относительно других... Соответственно приоритет отдаётся... То есть палочки - они не одинаковые, палочки имеют разный вес (интервью, Игорь, полковник в отставке, 2010 г.).

Сталкиваясь с тем или иным происшествием в контексте ведомственной логики, полицейские оценивают, имеет ли преступление потенциальный социальный резонанс или политическую подоплёку. Не менее важным для них является то, какой вклад работа над этим преступлением вносит в показатели, которых необходимо достигнуть; насколько его содержание соответствует разнарядкам, спущенным сверху:

Естественно, курс начальство задаёт: сегодня пьяных пишем, завтра - хулиганов, послезавтра - по торговле и т. д., сами знаете. Я к чему веду: участковый по протоколам таким образом выполняет уже норму сотрудника ППС (Патрульно-постовой службы. - Е. Б.) среднего города!!! А что будет дальше? А ведь УУП и палки должен приносить, не говоря уж о материалах... (из дискуссии на онлайн-форуме сотрудников МВД РФ, 2015 г.).

Проверочные мероприятия по зарегистрированному происшествию должны быть проведены сотрудниками в рамках строго ограниченного времени. Для любого правонарушения существует срок исполнения, за который сотрудники обязаны оценить наличие состава преступления и принять правовое решение. Ответственность не только за качество проведённой проверки и обоснованность принятого решения, но и за соблюдение сроков лежит на сотрудниках. В результате правонарушения, поступающие в ведение полиции, начинают оцениваться в ракурсе вероятности успешного в плане статистической отчётности их разрешения. Как следствие, работа ведётся в первую очередь над делами, по которым возможно быстрое достижение положительного результата.

Шансы на раскрытие, причём в формально отведённые для этого сроки, - эвристический показатель, оценки которого полицейскими напрямую влияют на судьбу попавшего в их ведение дела. Регистрация «висяков» или «глухарей» либо максимально откладывается до лучших с точки зрения статистики времён, либо актуализирует ценностные порядки, выходящие за пределы ведомственной логики.

В отношении же «выгодных» с точки зрения отчётности преступлений работникам полиции «нужно» действовать осторожно. Ведь в соответствии с системой АППГ + 1 сегодняшний хороший результат основа для более высокого «плана» в будущем:

План регулярно нужно валить!!! Тут стахановцем быть не стоит (из дискуссии на онлайнфоруме сотрудников МВД РФ, 2013 г.).

Таким образом, ведомственная логика порождает в российской полиции плановую экономику «палок» - единиц статистической отчётности, позитивная динамика которых по сравнению с предыду- 
щим годом позволяет полицейским рассчитывать на то, что их официальная оплата труда, состоящая из постоянного мизера (ставка) и набора переменных - премиальных - доплат, будет выплачена в максимально возможном объёме. Сюда же интегрирована система сдерживания активности полицейских в раскрытии преступлений, так как в соответствии с системой АППГ + 1 сегодняшний хороший результат — основа для более высокого «плана» в будущем.

\section{Клановая логика: «у нас в отделе...»}

Клановая институциональная логика в деятельности российских полицейских отсылает к лояльности каждого сотрудника отделу полиции, в котором он служит. Достижения в данной логике вознаграждаются формальными и неформальными поощрениями со стороны начальника, а также вносят вклад в укрепление солидарности внутри отдела благодаря совместно достигнутому порядку на вверенной территории.

Коллективы подразделений российской полиции сегодня выстроены как мини-кланы, внешние и внутренние границы которых удерживаются авторитетом начальника.

Любая деятельность полицейских осуществляется с ведома начальства и выстраивается коллективно. Система требует от сотрудников беспрекословного подчинения начальству. Сомнения в обоснованности решений начальника жёстко пресекаются:

Пословица «Я - начальник, ты - дурак» для описания нашей жизни подходит идеально. Если ты критикуешь начальника - возбуждаешь сочиальную вражду. Между подчинёнными и руководителями... (из дискуссии на онлайн-форуме сотрудников МВД РФ, 2013 г.).

В полиции начальник несёт ответственность за деятельность своих сотрудников, причём личную. Дорога к увольнению начальника вымощена нарушениями его подчинённых (как следствие, провокации в отношении сотрудников могут становиться, и иногда становятся, способом смены начальства, средством «клановых войн»). Так, в 2012 г. в России за различные проступки подчинённых из органов внутренних дел были уволены более 1700 руководителей 6 . В то же время, в случае если нарушение подчинённого не ставит под угрозу позицию вышестоящего звена, именно начальник способен защитить его даже от серьёзных неприятностей.

От начальника зависит как возможность работать в системе, так и реальная заработная плата каждого отдельного полицейского.

Разлад с начальником, независимо от причины, зачастую означает, как минимум, переход в другое подразделение или даже уход из правоохранительных органов:

Знакомая рассказала, что пришла на собеседование к нач[альнику] МОБ (Милиция общественной безопасности. - Е. Б.) по поводу устройства дознавателем. Он ей прямо в лоб: мол, будешь со мной «дружить», получишь меньше дежурств, перспективные дела и пр [очие] привилегии, а если нет, завалим материалами и т. д. (из дискуссии на онлайн-форуме сотрудников МВД РФ, 2012 г.)

В функционал начальников входит и распоряжение бюджетом отдела, в том числе (как будет показано далее) и неформальной его частью:

6 Из интервью с главой МВД В. А. Колокольцевым; см.: URL: http://ria.ru/society/20130210/922151468.html 
Он может лишить надбавок, может повесить выговор, чтобы премии потом не давать (интервью, Влад, участковый, 2010 г.).

Способствует развитию клановой логики в российской полиции и то, что деятельность большинства полицейских подразделений жёстко привязана к определённой территории. Территориальная привязанность является фоном для усиления внутригрупповой солидарности внутри отдела, превращения последнего в «коллектив». Фактически здесь включается различение «своё - чужое», традиционный драйвер формирования сообществ. Территориальность работы полицейских придаёт ей моральное измерение, переводит контроль и спокойствие на «своей земле» в термины хорошо проделанной работы:

В городе, как грибы, растут законные и незаконные точки по продаже салютов, поступает море жалоб от граждан. Кто как борется с ними? Особенно интересуют домушники - те, кто торгует с квартир, штрафы за это космические, начальство сказало разобраться. Работал, знаю тему. Особенно меня бесило, когда детям мальмм мощные изделия барыги продавали. Лишь бы бабло срубить. Очень плохо было таким продаванам... (из дискуссии на онлайн-форуме сотрудников полиции РФ, 2015 г.).

Удовлетворение благодаря коллективно достигнутым результатам способно выступать значимой мотивацией полицейских. Возможность опереться на коллектив, ориентироваться на фигуру начальника оказывается мотивационным ресурсом, выходящим за границы формального стимулирования:

Раньше прежде всего уважали своих начальников, а они этого заслуживали. Это был один из поводов работать, не оглядываясь на свои права (из дискуссии на онлайн-форуме сотрудников полиции РФ, 2014 г.)

Таким образом, при оценке ценности правонарушений в русле клановой логики принципиально важным оказывается следующее: во-первых, насколько работа над данным делом соответствует задачам, поставленным перед отделом начальником; во-вторых, насколько работа над данным делом позволяет обеспечить отчетные показатели отдела; в-третьих, насколько работа над данным делом важна с точки зрения удержания порядка на вверенной отделу территории.

В целом же клановая институциональная логика призывает полицейских к беспрекословной лояльности отделу и особенно начальнику в обмен на благорасположение последнего, повышение шансов на получение в разработку перспективных дел и, как будет показано далее, возможность участия в неформально оплачиваемом силовом предпринимательстве.

\section{Квазирыночная логика: «не служить, а зарабатывать»}

К ситуациям, когда полицейские принимают рабочие решения с расчётом на извлечение материальной выгоды, отсылает квазирыночная логика. В этом случае происшествия, правонарушения, преступления обретают ценовое измерение.

Почему для обозначения данной логики видится необходимым использование приставки «квази-»?

На протяжении последних трёх десятилетий одним из лейтмотивов и публичных, и научных дискуссий о российской полиции является соображение о том, что сотрудники постсоветской правоохранительной системы отказались от следования общественному долгу в угоду личным материальным интересам, максимизируемым через эксплуатацию властного ресурса [Коленникова, Косалс, Рывкина 2004; Дубова, Косалс 2012]. Установка на извлечение финансовой выгоды из должностных полномочий - 
это то, что теоретически в полицейской организации не должно было возникнуть ни при каких условиях, то есть инверсия, маркирующая полицейских как «оборотней в погонах».

В соответствии с ч. 4 ст. 34 Федерального закона № 342-Ф3 «О службе в органах внутренних дел Российской Федерации и внесении изменений в отдельные законодательные акты Российской федерации» (2011), или, как обычно говорят респонденты с «законом о запрете на подработки», сотрудники правоохранительных органов не имеют права работать по совместительству нигде, кроме педагогической, научной и творческой областей. Нарушение данного запрета автоматически запускает дискурс о нарастающей коммерционализации и коррумпированности этого института. И хотя к настоящему моменту контуры коммерционализированной деятельности российских полицейских изменились по сравнению с началом 1990-х гг. [Maksimova, Kosals 2013], отрицать распространённость неформальной экономической деятельности в полицейской среде пока нельзя.

Сильным аргументом в пользу нормализации квазирыночной логики, без которой невозможна её имплементация, стало недофинансирование, имевшее место в 1990-е гг, за которым российские полицейские - обоснованно или ища оправданий - видели негласный контракт с государством.

Использование государством подобных негласных контрактов не является инновацией. В 2000 г. Януш Корнаи продемонстрировал этот механизм на примере здравоохранения, показав, что весьма умеренные заработные платы врачей в Венгрии являлись результатом целенаправленной политики государства: оно считало широкое распространение неформальных платежей наименее болезненным решением для экономики [Kornai 2000: 4]. Валидность идеи Корнаи обретает реальные очертания, когда в ходе интервью с российскими полицейскими выясняется, что они воспринимают свою низкую зарплату не как беду, с которой нужно либо мириться, либо бороться, а как негласное подтверждение их права на неформальные подработки:

Чем правоохранительная система отличается в нашей стране, так это тем, что приходится добирать себе зарплату, приходится искать приработок (из дискуссии на онлайн-форуме сотрудников полиции РФ, 2011 г.).

Недофинансирование воспринималось как намёк на то, что государство ожидает: полицейские не просто прокормят себя сами, но ещё за собственный счёт будут содержать правоохранительную систему в стране. Примеры того, что производственные издержки ложатся на плечи сотрудников, долгое время были многочисленными:

Коллеги, понимаю, что это происходит повсеместно, я регулярно, как и все, приобретаю канцтовары, заправляю картридж принтера (который, естественно, купила сама), покупаю бумагу и прочее, но всему наступает предел. После очередных «сладких» речей начальник ОПа (Отдел полиции. - Е. Б.) УМВД России по г. <... > Тупняков на вопрос: «Почему нас не обеспечивают необходимым?» - сказал: «Не жалуйтесь, у вас достойная зарплата... Не обеднеете» (из дискуссии на онлайн-форуме сотрудников полиции РФ, 2013 г.).

Способствовало нормализации неформальной экономической деятельности и искажение трактовки законодательной статьи о запрете на подработки. На практике он интерпретируется полицейскими как запрет на подработки деятельностью, не связанной с правоохранительной. Признавая, что полицейским нельзя заниматься частным извозом или работать в частной охране, сотрудники склоняются к мысли, что запрет на подработки за пределами системы не означает реального запрета на подработки внутри самой системы, особенно если это не мешает выполнению прямых обязанностей: 
Они ж и не зарабатывают на стороне. Они берут вознаграждение за какие-то неформальные действия, санкиии... Полицейские должны деньги зарабатывать с помощьью выполнения непосредственно своих обязанностей. И работать непосредственно на своей должности. Кузнеи должен зарабатывать деньги тем, что он хорошо делает свою работу, к нему идут там... заказывают. Повар зарабатывает тем, что он хорошо готовит, кнему приходят и кушают с удовольствием. А мент должен зарабатьвать тем, что он должен хорошо преступников ловить и в тюрьму их сажать» (интервью, Арсений, оперативник, на пенсии, 2010 г.).

В России неформальная экономическая деятельность сотрудников полиции, скорее, носит системный характер, как минимум, потому, что всегда осуществляется с ведома начальства. Неформальные платежи за спиной начальника - это дополнительные риски как для начальника, так и для самого сотрудника, за которого, кроме начальника, некому заступиться.

Масштабные неформальные денежные потоки также организованы вертикально, и пороговые рубежи охраняются высокопоставленными сотрудниками. Так что там, где сотрудник делает выбор в пользу получения денег вместо выписывания протокола, вырученные средства едва ли направляются в его личный карман: в дело опять вступает план, правда, на этот раз финансовый.

Всё зависит от того, какая у них ёмкость чемодана, насколько она велика. Или выполнили ли они уже свой суточный план и насколько (интервью, Арсений, оперативник, на пенсии, 2010 г.).

Таким образом, приказной и коллективный характер участия в неформальных экономических сделках обеспечивает критическую массу аргументов, оправдывающих обращение российских полицейских к прибылеориентированной логике.

При анализе квазирыночной логики есть возможность обратиться к наработкам теорий оценивания, сделанным в ходе исследований маркетизации благ. В этом контексте принципиальное значение имеет вопрос о том, идёт ли речь об оценивании стандартизованных благ, или проблема оценивания возникает в ходе движения благ сингуляризированных. Полномочия российских полицейских делятся на три группы: бюрократически-лицензионные, социально-сервисные и репрессивно-надзорные [Гладарев 2011].

В случае бюрократически-лицензионной деятельности полицейских можно говорить о потоке стандартизованных операций, коммерционализация которых по своему формату достаточно близко приближается к рыночному, если понимать под рынком «регулярные, опосредованные главным образом деньгами, взаимовыгодные и добровольные с точки зрения обеих участвующих сторон» сделки [Радаев 2006: 27; 2007: 17]. До недавнего времени ярким примером такой деятельности могли считаться покупка водительских удостоверений или решение вопросов, связанных с регистрацией в ГИБДД технических средств. Стоимость подобных неформальных услуг была фиксированной. Оплачивающие данные услуги граждане экономили силы и время на прохождении соответствующих проверок.

Особняком стоят практики, связанные с силовым предпринимательством. Это работа по обеспечению безопасности и разрешению споров, которая и без того входит в обязанности полицейских, но материально стимулируется бизнесменами на реципрокных основаниях или в форме незначительной абонентской платы:

Просто, если я, будучи коммерсантом, позвоню в дежурную часть, я этого приезда буду ждать... Быстрее сам решу свою проблему. А так я просто звоню «другу», который тут же направляет ко мне машину (интервью, Сергей, участковый, 2010 г.). 
Что касается социально-сервисных и репрессивно-надзорных функций, то они коммерционализируются, скорее, по модели сингулярных благ, где каждая из сделок является эксклюзивной и нет чётко выстроенных механизмов определения цены.

Примером подобной практики могут быть, например, переговоры по поводу возможности развала уголовного дела. И условия сделки, и её цена оказываются договорными и зависят от множества факторов: важны личность, должность, социальный статус и правонарушителя, и его посредников, степень серьёзности их контактов в полиции. Особую роль играют степень тяжести совершённого преступления, общественный резонанс, связанный с таким типом преступлений, потенциальная опасность обвиняемого (определяемая полицейскими по своему опыту) и многое другое. Цена эксклюзивной сделки просчитывается начальником подразделения:

Он - начальник, он знает, сколько будут стоить затрать на производство подобного вида расследования. Какой человеческий ресурс, какой административный ресурс, какой материальный ресурс потребуется... (интервью, Арсений, оперативник, на пенсии, 2010 г.).

Ключевым фактором ценообразования в данном случае оказывается «длина цеепочки», то есть число сотрудников, вовлечённых в расследование (если требуется закрыть дело), или тех, которых необходимо к нему привлечь.

Таким образом, квазирыночная институциональная логика, взращённая в ходе буйной коммерционализации полиции в 1990-е гг., таит в себе шансы на получение полицейскими дополнительного денежного заработка за выполнение (а иногда, наоборот, за невыполнение) своих непосредственных рабочих обязанностей.

\section{Профрессиональная логика: «от Москвы и до Карпат опер оперу друг и брат»}

Профессиональная логика в деятельности полицейских обобщает целый ряд установок сотрудников правоохранительных органов, связанных с пониманием субстантивных задач и нормативных оснований своей деятельности. Ключевой ценностью является реализация сотрудниками собственного призвания, и именно в свете того, насколько работа над тем или иным делом способствует этому, происходит оценивание.

С социологической точки зрения о сформированности профессиональной группы можно говорить при наличии таких составляющих, как взаимная идентификация и ощущение принадлежности на основе сходства деятельности, ведущее к установлению органической солидарности между членами этой группы, особые знания и навыки, из которых вытекает профессиональная власть, основанная на компетентности, профессиональная этика, профессиональная автономия и претензии на престиж в обществе [Friedson 1988; Abbot 1993; Гадеа 2011].

Тесная связь российской полиции с государством, её централизованность, едва ли позволяет говорить о возможной автономности данной группы. Тем не менее Федеральный закон «О полиции»» (от 07.02.2011 № 3-Ф3, ст. 31) не запрещает полицейским объединяться в профсоюзы, формировать профессиональные ассоциации, то есть вполне допускает возможность консолидации полицейских, в том числе ради укрепления своих прав и защиты профессиональных интересов ${ }^{7}$. И на территории России действуют как международные полицейские ассоциации, так и всероссийская ассоциация. Что касается знаний и навыков полицейских, то в России, как и во многих странах Европы (и в отличие от США,

7 См.: URL: http://www.consultant.ru/document/cons_doc_LAW_110165/ 
где полицейские образовательные учреждения предлагают лишь программы специализированной переподготовки для лиц с высшим образованием), осуществляется специализированная ведомственная подготовка полицейских, уровень которой теоретически должен приравниваться к уровню дипломов гражданских вузов. В 2013 г. Приказом Министерства образования и науки РФ № 513 «Об утверждении Перечня профессий рабочих, должностей служащих, по которым осуществляется профессиональное обучение» полицейские вошли в данный перечень ${ }^{8}$.

При этом с 2009 г. в России введено правило, в соответствии с которым курсанты ведомственных вузов, обучающиеся на бюджетной основе, обязаны отработать в правоохранительных органах не менее пяти лет после окончания обучения (или вернуть государству деньги, потраченные на обучение). А годом ранее, в 2008 г., Приказом МВД РФ был утверждён кодекс профессиональной этики сотрудника органов внутренних дел РФ, призванный регулировать должное поведение полицейских 9 . И хотя, по данным интервью, сами полицейские относятся к данному документу с иронией, важен факт институционализации полиции в России как профессии.

Советская милиция считалась профессиональной группой, характеризовалась «собственным корпоративным духом и профессиональной этикой, обладающей мощным морально-мотивационным зарядом» [Гладарев 2011: 137]. Однако слом советской правоохранительной системы способствовал размыванию профессиональной идентичности и моральных устоев недавних милиционеров [Shelley 1996]. По сравнению с советским периодом границы профессиональной идентичности российских полицейских меняются. И тем не менее профессиональная идентификация сохраняет своё смыслообразующее значение для сотрудников правоохранительных органов. Ощущение себя полезным дорогого стоит. Полезность же задаётся заострённостью деятельности на борьбе с «отпетыми уголовниками» и накопленным с опытом экспертным знанием в области адаптации идеологически абсолютизированного закона к реальной жизни:

Лично я горжусь тем, что защищщал простых людей от воров, грабителей и бандитов (из дискуссии на онлайн-форуме сотрудников полиции РФ, 2013 г.);

Я один раз заглянул в кабинет к старому оперу, так вот, он сидел и по-доброму беседовал с мужичком одним. За жизнь. Когда мужичок ушёл, я поинтересовался: «Знакомый?» Да нет, отвечает, разбойник. Семь лет назад его посадил. Вот освободился, пришёл проведать меня <...> Раньше ТАК работали (из дискуссии на онлайн-форуме сотрудников полиции РФ, 2013 г.).

Контроль правонарушителей и удержание границ между преступными и непреступными деяниями тесно связаны с представлением сотрудников о том, чем в действительности должны заниматься полицейские, в чём заключается ценность их работы.

Основной в шкале оценивания правонарушения в русле профессиональной логики является оппозиция «безобидность - серьёзность». Правонарушения соотносятся с нормами Уголовного кодекса, классифицирующего преступления по степени тяжести. Параметр преднамеренности рассматривается как отягощающий фактор.

Границы профессиональной группы российских полицейских не исчезают. Настроенность бороться с преступностью вкупе со стремлением делать это, оставаясь в правовом поле, позволяет обособиться

8 Cм.: URL: http://base.garant.ru/70433916/\#block_1000\#ixzz4J6JhR6m4

9 Cм.: URL: http://www.garant.ru/products/ipo/prime/doc/1257019/ 
от силовых групп. А обладание властными полномочиями, имеющее множество объективированных проявлений, мешает слиться с «гражданскими»:

Я так думаю, есть же жизнь и за пределами полиции, хотя я, если честно, не представляю, как без неё жить, меня все знают как ПОЛИЦЕЙСКОГО, я привык так жить - звонки, проблемы, люди... Вопросы решаются быстро. С принятием решения об уходе ешё не ушёл, а уже всё прекратилось - контакты, люди, связи, звонки... Все махом куда-то исчезли, хотя ещее даже не уволился. Это, конечно, очень тяготит и угнетает (из дискуссии на онлайнфоруме сотрудников полиции РФ, 2014 г.).

Работа в полиции - это не только особый образ жизни, но и профессиональная карьера, этапы которой маркируются получением званий, а финальным рубежом, где оценивается качество пройдённого профессионального пути, является пенсия. При этом важно понимать, что полицейская карьера может заканчиваться достаточно рано, если сравнивать с гражданскими специальностями. По выслуге лет органы могут покидать 40-летние люди. И потому пенсия рассматривается не столько в связи с её покупательной способностью, сколько в ракурсе того, насколько она суммирует карьерные достижения. Возможно, так происходит и потому, что, как свидетельствует расхожая дискурсивная формула, «noлицейский бывшим не бывает» - в силу ли того, что работа в полиции предполагает, что даже после увольнения можно пользоваться определёнными ресурсами, связанными с доступом в правоохранительную систему, или же потому, что профессиональная идентификация долгие годы определяет образ жизни.

А я уже второй год работаю в банке. Всё меньше и меньше хочется бывать в родных ранее стенах. Всё реже хочется оправдывать нелицеприятные поступки сотрудников. Но всё ещё болезненно переношу «ругательные» статьи про милицию в прессе и фразу «менты-козльл» (из дискуссии на онлайн-форуме сотрудников полиции РФ, 2012 г.)

Таким образом, на уровне практики российских полицейских профессиональная логика по своим установкам максимально приближена к субстантивному понятию «служение» и отсылает к внутренней мотивации профессионализма и солидарности со своим «кружком экспертов» [Гадеа 2011: 24]. В практической классификации происшествий она высвечивает преступления, получение позитивного рабочего результата по которым становится для полицейских «делом чести».

\section{Четыре логики в одной системе: диссонанс, который не пришлось организовывать}

Основным вопросом данной работы являлось то, в каких ценностных координатах российские полицейские оценивают происшествия, правонарушения и преступления, над которыми им приходится работать. Описанные логики дают представление о том, какие параметры оценки могут быть применены. Однако как описанные четыре институциональные логики соотносятся между собой? В какой мере они пересекаются, а в какой противоречат друг другу? Как взаимодействуют между собой при регулировании реального поведения полицейских? В каких ситуациях какая из них побеждает?

Данные предпринятого исследования дают основания предположить, что, хотя между описанными логиками существует условная иерархия, в ряде практических случаев они выступают как система сдержек и противовесов друг для друга и в итоге, действуя совместно, обеспечивают тот продуктивный диссонанс [Stark 2009], который позволяет полицейской организации хотя бы на минимальном уровне удовлетворять интересы всех заинтересованных акторов, не утрачивая легитимности. 
Принятие в 2011 г. нового Федерального закона «О полиции» (№ 3-Ф3) позиционировалось как мера по переходу от репрессивной милицейской организации к полиции, предоставляющей правоохранительные услуги населению. Потенциально речь шла о смене модели полицейской деятельности (policing) в стране. Но говорить о том, что данный переход состоялся, представляется преждевременным.

Список институциональных логик, направляющих рабочие решения полицейских, возглавляет ведомственная логика. Ориентированная на борьбу с преступностью, она помогает удерживать легитимность действующей государственной власти в глазах населения. Курс на централизацию полиции, взятый ещё в середине XIX века, когда государство экстренно мобилизовывало полицейские силы, опасаясь крестьянских бунтов после отмены крепостного права [Борисов, Малыгин, Мулукаев 2016], до сих пор остаётся актуальным. Любые порывы полицейских — в пользу ли коллективных интересов отдела, профессионального долга или даже дополнительного заработка - могут быть реализованы лишь после того, как будет выполнен «план раскрытия», необходимый для статистической отчётности и напрямую влияющий на законодательно заданные параметры формирования многосоставной и потому манипулятивной заработной платы.

На втором месте в иерархии ценностных порядков находится клановая логика. Возможно, из-за того, что в России полицейская организация остаётся милитаристской, подчинение распоряжениям командования, принцип «приказ есть приказ», как свидетельствует и данное исследование, не теряет своей актуальности.

Упрочению позиции клановой логики способствует и скрытая за ней совместная ответственность за территорию, которая закрепляет границы сообщества, что становится опорой для органической солидарности между сотрудниками одного отдела.

Сказанное не означает, что все многочисленные сотрудники российской полиции обязательно приписаны к клану. Отношения с начальником могут быть разными. Там, где они нарушены, как будет показано далее, возникают и риски для клановой логики.

Следующие два места в иерархии делят между собой квазирыночная и профессиональная логики.

Третье место квазирыночной институциональной логики в списке ценностных порядков неслучайно. Эта логика пустила глубокие институциональные корни в российской полиции, в том числе на уровне управленческого звена. Тем не менее поставить прибылеориентированность российских полицейских на более высокое место данные исследования не позволяют. В глазах полицейских получение денег за свою работу всё-таки тесно граничит с должностным преступлением, со взятками, «наглой корруnцией», и потому её применение не является рутинным. Границы применения этой логики тщательно отслеживаются. Они касаются и размера взимаемых платежей, и силы давления, с которой они получены, и характера правонарушения, плата за игнорирование и (или) сокрытие которого принимается полицейским, и баланса выполненных и не выполненных в связи с получением наличных денег должностных обязанностей. Случаи нарушения «меры» содеянного кем-то из полицейских привлекают внимание службы внутренней безопасности: «На особо зарвавшихся пепсов есть ОСБ» (из дискуссии на онлайн-форуме сотрудников полиции РФ, 2012 г.). Тех, кто считает, что получение денег вопреки рабочим обязанностям может осуществляться автоматически, в открытую «торгует ксивой» (интервью, Дмитрий, майор, 2015 г.), система выдавливает.

Проблему коррупции российские полицейские обсуждают как нечто внешнее по отношению к своей деятельности. Взяточничество, под которым полицейскими в основном понимается злостное наруше- 
ние должностных обязанностей в индивидуальном порядке и за очень большие деньги, скорее, не находит одобрения; неформальные практики, основанные на вымогательстве, и вовсе осуждаются.

К тому же реформы полиции, реализованные в последнее время, были результатом серии публичных скандалов («дело Евсюкова» ${ }^{10}$, «Обращение Дымовского к В. Путину» ${ }^{11}$ ), связанных с оппортунистическим поведением российских полицейских. Таким образом, реформа совпала с тенденцией к усилению служебных проверок в полиции, что сделало участие в неформальной экономической деятельности более рисковым и стигматизированным.

Хотя результаты данного исследования позволяют говорить о том, что полицейские предъявляют запрос на профессиональное признание, целый ряд тенденций в постсоветский период указывает на то, что профессиональная логика в российской полиции очень уязвима.

Кадровые чистки в ходе недавней реформы способствовали уменьшению числа опытных сотрудников, «выходцев старой школы». Это сказалось на возможности ретрансляции профессиональных ценностей:

Куда делись любовь к Родине и самоотверженность в обновлённой и отреформированной полиции? Они в основной своей массе ушли с теми, кто был невыгоден начальству, так как спина была заточена не под тем углом, чтобы поклоны бить. Только оперов до реформы по нашему округу раза три «чистили». «Поколение пехт» уже учат быть более «разумными». Вот и меняются понятия... (из дискуссии на онлайн-форуме сотрудников полиции РФ, 2013 г.).

Кренится профессиональная логика полицейских и в связи с инфляцией в области символического оценивания профессиональных достижений:

Да, звания обесченились напрочь. Раньше хозяин СИЗО с лимитом наполнения в 3200 человек и личным составом в подчинении в полтысячи человек, седой, сожравший зубы на чифире-потолок-подполковник ${ }^{12}$... Щас Вася Пупкин из пресс-службы - генерал-майор с иелым Управлением в штате... (из дискуссии на онлайн-форуме сотрудников полиции РФ, 2014 г.)

На смену старой гвардии пришли молодые кадры, отличающиеся, помимо прочего, юридической подкованностью, что даёт им дополнительные аргументы во взаимоотношениях с начальством.

Юридическая грамотность обновлённого личного состава сделала возможным и в условиях трудностей полицейской службы отстаивание индивидуальных прав сотрудников, то есть в пределе ещё и разобщила коллектив. Так, вместе с нанесением урона взаимоотношениям управляющего и рядового состава под удар попала и интегрерированность полицейского братства:

10 Дело Евсюкова - уголовное дело по обвинению бывшего майора милиции Дениса Евсюкова, открывшего стрельбу в московском супермаркете в ночь на 27 апреля 2009 г., в двух убийствах и 22 покушениях на убийство, а также в незаконном владении оружием и боеприпасами.

11 Майор МВД РФ А. А. Дымовский является лидером общественного движения за реформу правоохранительных органов «Белая лента». На личном веб-сайте (www.dymovskiy.ru) 5 ноября 2009 г. он опубликовал два видео, содержащих обращение к В. В. Путину и включающих описание различных недобросовестных практик, в том числе коррупционных, реализуемых сотрудниками российских правоохранительных органов. По итогам обращения в органах МВД РФ была реализована серия служебных проверок.

12 То есть выслуживший свой максимум. 
Нет коллективов с большой буквы - огромная потеря с тех славных времён.... (из дискуссии на онлайн-форуме сотрудников полиции РФ, 2015 г.).

Количественные исследования указывают, что лишь около $13 \%$ российских полицейских могут быть отнесены к группе полицейских по призванию. У этих сотрудников ярко выражены желание приносить пользу обществу и стремление брать на себя ответственность в работе. Они настроены профессионально развиваться, применять имеющиеся и приобретать новые знания и навыки, проявлять инициативу. Среди таких сотрудников высокая доля тех, для кого профессия полицейского - призвание: помимо стремления принести пользу обществу, для них работа в полиции является семейной традицией и важен интерес к содержанию работы [Максимова 2013: 141].

Описанные институциональные логики упорядочены друг относительно друга. Однако каждая из них имеет слабые места, что расширяет репертуар возможных решений со стороны сотрудников полиции. Когда в пределе цели деятельности, диктуемые разными логиками, оказываются близкими по сути, это ведёт к продуктивному на уровне системы пересечению различных логик, в противном случае - ставит российских полицейских перед лицом ценностных конфликтов.

Примером сочетания действия разных институциональных логик может быть ситуация, когда раскрытие резонансного преступления позволяет полицейским набрать очки по всем шкалам ценности, то есть вносит положительный вклад и в отчётность, и в отношения с начальством, и в групповую солидарность с отделом, и в профессиональную репутацию сотрудников. Звёздочки на погонах - значимая отметка и по ведомственной, и по клановой, и по профессиональной шкале.

Если допустить, что до недавнего времени государство действительно негласно готово было перераспределить издержки содержания правоохранительной системы в том числе в пользу её клиентов, то ситуации оплачиваемого силового предпринимательства, несмотря на свой неформальный и незаконный характер, тоже могут расцениваться как обладающие эффективностью.

Сотрудники съездили по вызову, привезли злодея, по протоколу его допросили. Ещё и палку срубили. У меня (коммерсанта) официальная жалоба (заявление пишу) на то, что происходит (интервью, Влад, участковый, 2011 г.).

Не всегда получение денег полицейскими означает, что правонарушитель ушёл от наказания. И в этом смысле преодоление преступности - задача, которая под разным соусом подаётся и в ведомственном, и в клановом, и в профессиональном ключе. С учётом большой легитимности этих трёх логик в глазах сотрудников, даже в случаях, когда урегулирование происшествия осуществляется посредством денег, речь необязательно идёт об элиминировании необходимых санкций. Скорее, полицейские берут на себя задачу выстраивания баланса интересов между виновником и пострадавшим в случаях, когда, по их профессиональному мнению, это возможно. Показательным в данном контексте является следующий реальный случай. В результате ДТП между водителями, один из которых - пожилой человек, а другой - юноша, следовавший за покупками вместе с родителями, завязывается драка. Пожилому человеку, который при этом не виноват в ДТП, наносится травма средней тяжести, повлёкшая медицинскую операцию. Расследование ситуации однозначно указывает на виновность юноши, родители которого предпринимают усилия, чтобы спасти его от тюремного заключения. На определённом этапе расследования со стороны обвиняемого выдвигается предложение решить вопрос «полюбовно», выплатив материальную компенсацию потерпевшему, и тот соглашается при условии, что юноша будет отправлен на принудительное лечение в психиатрическую клинику как склонный к аффективным действиям. Очевидно, что приостановка и закрытие дела на таком этапе требует материальных затрат от обвиняемого. Таким образом, вся ситуация разрешается при помощи денег. Можно ли говорить, что нарушитель не 
понёс наказание? Можно ли говорить, что потерпевший столкнулся с давлением и был вынужден взять деньги? Можно ли говорить, что полиция проигнорировала случай правонарушения как таковой? Пожалуй, складывается ситуация, когда путём смягчения жёсткого закона при помощи полицейских был выстроен альтернативный консенсус, некая бытовая форма правосудия между сторонами.

Нехорошей считается взятка - отпускать преступника за деньги. Вот если преступник договорился с потерпевшим, это другое дело. Здесь очень тонкая грань. Средняя полицейская мораль считает, что если никто не пострадал, то деньги взять можно. Хотя при этом есть полицейские, которые подкидывают наркотики, потом сами вымогают деньги, но это считается нехорошо. Если, правда, человек был бы виноват, то тогда это нормально (интервью, Вадим, отдел МВД, 2011 г.).

За кажущейся благостностью описанной в примере выше картины скрывается ещё одно различение, сделавшее подобное разрешение ситуации возможным. Речь идёт о факторе силового давления на участников. В описанной ситуации отсутствие такого давления позволило выйти из ситуации с внесением неформального платежа. Для занятых в деле полицейских эти деньги стали заработком «с чистой совестью». В случае же, когда деньги полицейским платят под давлением с их стороны, платёж классифицируется как вымогательство и осуждается.

Квазирыночная логика удерживается в рамках за счет профессиональной и ведомственной и попутно решает задачи, поддерживаемые ими.

При этом условием для реализации квазирыночной логики является её подчинённость клановой.

Как уже было сказано, масштабные денежно ориентированные сделки не могут осуществляться без ведома начальства. Начальники выступают медиаторами, обеспечивающими встречу спроса и предложения на неформальные услуги полицейских. В том числе и потому, что именно руководитель отдела, управления и т. д. (в зависимости от серьёзности дела) является информационным центром, благодаря которому «решение вопроса за деньги» не приведёт к системному сбою, не вступит в противоречие с другим отделом или управлением.

Деятельность российского полицейского никогда не выстраивается как автономная. Над делом зачастую работают несколько сотрудников, а если дело серьёзное, то и несколько отделов. В таком случае попытка решить вопрос на уровне отдельного сотрудника является бессмысленной: он не может принять решение без ведома начальника, а тот, в свою очередь, должен соотнести своё решение, например, с информацией о том, интересы каких служб могут быть поставлены под угрозу, если дело будет закрыто. Таким образом, клановая логика контролирует потенциальные разрушительные эффекты логики квазирыночной - для правоохранительной системы в целом.

В свою очередь, применение квазирыночной логики может укреплять саму клановую логику. Вовлечённость сотрудников в неформальные экономические сделки становится инструментом контроля и управления сотрудниками внутри подразделения. Допускаемое начальством участие сотрудников в неформальных экономических практиках - ещё и способ держать их «на крючке», поддерживать механизм «круговой поруки». Таким образом, в руках начальника квазирыночная логика является одновременно и источником дополнительных денежных вознаграждений сотрудников (что в том числе препятствует кадровой текучке), и инструментом санкций.

Примером трения между институциональными логиками может стать противоречие между ведомственной и профессиональной логиками в работе полиции. В то время как первая ориентирована на 
результат «бери больще, кидай дальще», вторая акцентирует приоритет рабочего процесса над результатом.

Лишения, которые влечёт за собой негативная динамика показателей, в форме нивелирования премий сотрудникам и т. п. делают изначально второстепенный по своей сути вопрос получения «палок» основной целью деятельности. В совокупности с тем, что вся работа выполняется сотрудниками «на скорость», неудивительно, что система АППГ + 1 воспринимается как противоречащая реальным потребностям рабочего процесса:

Я никогда не откажусь и от нескольких суток работы. Главное, чтобы работа была, а не её видимость. Когда служба превращается в спектакль, в нечто глупое и не нужное никому, кроме руководства, тогда задумывваешься: а нужно ли рваться? Ответ очевиден: нет (из дискуссии на онлайн-форуме сотрудников МВД РФ, 2014 г.).

Погоня за показателями вынуждает полицейских перенаправить усилия на поиск дел, легко конвертируемых в «палки».

Сотрудникам полиции становится выгоднее раскрывать или предотвращать наиболее простые виды правонарушений, которые позволяют демонстрировать хорошие количественные показатели в отчётах. А сложные, требующие больших временны́х и физических затрат правонарушения оказываются в меньшем приоритете.

Неадекватные требования ведомственной статистики порождают целый ряд недобросовестных практик, наносящих урон профессиональной идентичности полицейских. Среди них и проблема нерегистрируемых происшествий, которые либо вообще не попадают в отчётность, либо регистрируются с временными подвижками, чтобы не портить статистику текущего календарного периода и не увеличивать объёмы бумажной работы.

Ещё один пример нарушения профессионального полицейского процесса - это усилия по переквалификации дела ради отчётных показателей. В целом определение тяжести преступления входит в базовый набор задач, которые приходится решать полицейским. При этом, как и в других сферах, процессы квалификации и переквалификации блага не могут происходить в отрыве от процессов их оценивания [Каллон, Меадель, Рабехарисоа 2008]. И, например, статистику можно улучшить, ужесточив тяжесть раскрытых преступлений или, альтернативно, понизив тяжесть нераскрытых. Иной способ улучшить отчётность - найти фиктивных обвиняемых или ввести в дело дополнительных фигурантов и тем самым, квалифицировать преступление как групповое, что ужесточает многие пункты российского УК. В репертуар факторов принятия решений входит давление на имеющихся обвиняемых для того, чтобы они взяли на себя ответственность и за другие преступления, широко критикуемое в публичном дискурсе силовое принуждение задержанных к даче признательных показаний.

Система оценки деятельности полиции по принципу АППГ + 1 является значимой угрозой для профессиональной интеграции и солидарности полицейских в России. Она нарушает слаженность работы разных подразделений, способствует внутреннему расколу системы, стимулирует конкуренцию за «палки» между её различными структурными подразделениями.

Конкуренция развивается не только между подразделениями, работающими параллельно, но и между структурами, являющимися звеньями одной и той же «производственной цепи» по раскрытию преступлений. Из единой корпорации, работающей на общую цель - обеспечение правопорядка и сокращение уровня преступности, - система МВД превращается в совокупность обособленных структурных 
единиц, связанных между собой функциональным разделением труда в рамках решения общей задачи, но в то же время борющихся друг с другом за то, чтобы вклад «своего» подразделения в общее дело был оценён более высоко, чем вклад «чужого».

По большому счету система должна как работать? У участкового - своя задача, у опера своя, и это всё в общую копилку. То есть слаженные действия различных служб должны приносить результаты. А происходит так, что каждая служба до потери сознания начинает работать в одном направлении, не привлекая ни оперов, ни остальных (интервью, Сергей, участковый, 2010 г.).

Конфликт между клановой и профессиональной логиками становится виден через смысловое противопоставление сотрудниками полиции «начальника» «командиру». Первое актуализирует бюрократические, формальные функции управленческого звена, подчинение которому в таком случае направляется стремлением избежать санкций. Второе отсылает к профессиональному авторитету, управленческим ресурсом командира является уважение. Если начальнику удаётся стать командиром, он оказывается частью коллектива, что становится дополнительной основной для сплочённости и значимым стимулом к работе. В противном случае в отношениях с ним сохраняется дистанция.

Данные дают основания предполагать, что разрыв между ролями начальника и командира возник и развился в 2000-е гг. По-видимому, в этот период перед МВД встала задача оценки эффективности работы полицейской организации («палки, палки, палки») и тесно связанной с ней необходимости оптимизации бюджетов на деятельность правоохранительных органов. Давление на управляющий состав формальных показателей и необходимости экономить фонд оплаты труда усилилось, что актуализировало и роль формальных институтов поощрения и наказания сотрудников. Всё это усугубляет разрыв между понятиями «командир» и «начальник». Клановая и профессиональная логики обособились друг от друга, хотя в советской милиции, похоже, они были неразрывно связаны:

Сравнивая прошлое и нынешнее, прошлое вспоминается с удовольствием. Не было денег командиры закрывали глаза на подработку, которая не нарушала закон. Бывало три месяца не платили, но был коллектив, и мы продолжали работать. Командир - кто это? Это отеи, который в сложной ситуации подскажет, поможет, поругает, но за тебя пасть порвёт. И, видя это, мы сами за ним шли и в пекло, зная, что сдохнем здесь. А сейчас сидит этот, он ни улицы не видел, ни смерти, ни жулика, зато щеки дует и пытается показать, какой он главный. И кричит он: ВЫ ОБЯЗАНЫ, ВЫ ФОРМУ ОДЕЛИ... А про свои обязанности он забыл. Попробуйте сказать здесь, что командир обязан заботиться о личном составе! Сразу будут кричать: вы что, в детский сад пришли? Я не говорю про всех, есть командиры, а не начальники ещеё, но их очень мало (из дискуссии на онлайн-форуме сотрудников МВД РФ, 2015 г.)

\section{Заключение}

В статье предпринята попытка показать, что, принимая рабочие решения, полицейские балансируют между требованиями государства, обязательствами перед населением, выполнение которых обеспечивает легитимность и института полиции, и господствующей властной группы, отношениями с начальством, профессиональным долгом и желанием навести порядок на вверенной территории, стремлением улучшить своё материальное положение и сохранить профессиональную идентичность. Анализ ситуации сквозь призму теоретического подхода институциональных логик позволяет увидеть, что решения принимаются сотрудниками на фоне институционально укоренённой конкуренции ценностных порядков, пусть и неодинаково легитимных. Этот подход даёт возможность заметить хитросплетения и противоречия между ценностными порядками, и в этом состоит значимый вклад представленного в 
статье исследования в понимание пространства факторов, в котором действуют российские полицейские. Особым образом результаты нашего исследования освещают и актуальный в постсоветские годы сюжет о неформальной экономической деятельности в российской полиции, тесно граничащей с проблематикой коррупции.

В целом, социологические исследования неформальной экономической активности российской полиции придерживались стигматизирующего подхода к изучению коррупции, оптика которого всегда направлена на поиск способа элиминировать коррупцию. Ключевая теоретическая дискуссия о природе и происхождении неформальной экономической деятельности полиции в научной литературе представлена тремя авторитетными подходами: (1) подход «испорченного яблока» («bad apple» approach) сводит причины полицейской коррупции к произволу отдельных сотрудников [Alpert, Walker 2000]; (2) подход «бочки дёгтя» («bad barrel» approach) призывает искать истоки любых профессиональных деформаций полицейских в условиях их работы, фокусируется на системных факторах возникновения полицейской коррупции [Perry 2001; O’Connor 2005]; (3) подход «засохшего сада» («rotten orchard» approach) ставит во главу угла вопрос об определённых сочетаниях системных и индивидуальных параметров на фоне общей институциональной обстановки в определённом государстве [Punch 2003].

Данные описываемого исследования указывают на то, что личная выгода конкретного сотрудника фактор, который внутри правоохранительной системы никак не является ведущим. Неформальная экономическая деятельность российских полицейских не может начаться раньше того, как будет выполнен «план раскрытия», необходимый для статистической отчётности и напрямую влияющий на законодательно заданные параметры формирования заработной платы. Неформальные платежи вместо штрафов начинаются, когда уже закончились протоколы. Кроме того, неформальная экономическая деятельность полицейских не может осуществляться без оглядки на закон и должностные обязанности. Не только из-за формального запрета на подработки и антикоррупционных законов, но и потому, что нельзя быть бывшим полицейским, как нельзя абстрагироваться от своих непосредственных обязанностей даже тогда, когда их нарушаешь. Именно поэтому полицейские ищут оправдания своей неформальной деятельности в низкой заработной плате, якобы свидетельствующей о том, что государство формально запрещает, но на деле закрывает глаза. И даже там, где деньги берутся взамен законом назначенных санкций, сама плата частично обеспечивает санкции за нарушение правил. Дело не только в том, что сами полицейские боятся наказаний. Представляется, что правильнее говорить о том, что они в действительности видят суть своей деятельности в преодолении преступности, в борьбе с нею, но не любое нарушение закона гражданами в их понимании является преступным. Формальная рамка всегда у́же социальной реальности. И кому, как не полицейским, постоянно сталкивающимся с несоответствием формальных законов реальным практикам, об этом знать.

Значимыми результаты представленного исследования являются и в контексте реформирования российской полиции. В первую очередь потому, что реформирование полиции не может не затрагивать систему оценки её эффективности. Хотя в процессе реализации недавних реформ неоднократно говорилось об отказе от «палочной» системы, на деле и она сама, и её многочисленные дезорганизующие эффекты по-прежнему сохраняются.

Надёжная система оценки деятельности сотрудников должна, с одной стороны, оказывать прямое и положительное влияние на их мотивацию, а с другой - оставлять возможность для коррекции этого поведения через систему стимулов. Принципиально важно, чтобы система оценки позволяла зафиксировать прогресс в плане достижения целей полиции. Для России это означает прежде всего необходимость определиться с тем, чего же общество ожидает от данного органа. 
Установка на борьбу с преступностью требует сокращать уровень преступности, выявлять, регистрировать и раскрывать преступления. Таковы нынешние ожидания по отношению к российской полиции. Однако исследователи уже несколько десятилетий настаивают на том, что подобный подход порочен, а соответствующие ожидания общества завышены [Хu 2013]. Уровень преступности в стране определяется большим количеством социоэкономических, политических, культурных факторов, а посему как рост преступности не может вменяться исключительно ответственности полицейских, так и снижение уровня преступности едва ли может быть отнесено на счёт успешной деятельности полиции.

Отрицательные последствия системы АППГ + 1 на уровне взаимоотношений сотрудников также являются критической проблемой. В связи с этим одним из наиболее важных направлений преобразования системы формальной оценки представляется введение непротиворечивой системы показателей для оценки работы различных подразделений, которая бы позволила преодолеть сложившуюся атмосферу конкуренции и разобщённости и не допускала дальнейшего противопоставления сотрудников и служб друг другу.

Дэвид Старк говорит о том, что в условиях организационной комплексности проблемой может быть не наличие множественности принципов оценивания, а то, что имеющихся логик недостаточно [Старк 2009]. В унисон с этой теоретической идеей в рамках недавней реформы российской полиции возникло предложение по внедрению в систему оценивания российских полицейских такого показателя, как удовлетворённость населения, замеряемого при помощи массовых опросов. Подобное преобразование может дать свои плоды, так как в любом случае пошатнёт имеющуюся иерархию ценностных порядков. Однако, возможно, реформаторам, стремящимся к преобразованию российской полиции по образцу американской системы community-policing (полиция для сообщества), важно отдавать себе отчёт в том, что государство и гражданское общество представляют собой различные типы институциональных акторов, интересы которых не полностью пересекаются. Кроме того, даже если не принимать во внимание содержательные и технические искажения, скрытые за лобовым определением уровня удовлетворённости населения полицией, скорее всего, выведение системы пусть и из шаткого, но равновесия принесёт позитивные плоды только в том случае, если вместе с ним будут дополнительно подпитаны институциональные логики, следование которым удерживает лучшее, что есть в системе.

Исследования динамики институциональных полей указывают на то, что драйвером изменений способна стать профессиональная логика [Greenwood, Suddaby, Hinings 2002]. Её усиление возможно при снятии хотя бы отдельных противоречий, возникающих в связи с существующей системой отчётности, например, при совмещении количественных показателей результата с качественными показателями процесса, а также при сокращении объёма бумажной работы по делам с отсутствием состава преступлений и т. п. В пользу профессиональной логики сработало бы и переведение части государственных услуг, например, бюрократически-лицензионных, в другие ведомства и, возможно, на изначально платную основу. Этому вектору отвечает, например, тот факт, что сменой водительских прав с 1 ноября 2016 г. в России будут заниматься многофункциональные центры (МФЦ). Подобные меры приближают ситуацию, когда в ведении полиции останутся вопросы, близкие по сути к тому, что полицейские считают «настоящей работой».

В заключение видится важным задаться вопросом о границах предпринятого исследования. Нужно признать, что они весьма зыбки. Множество тем, возникающих в ответ на вопрос о том, как полицейские оценивают дела, поступающие в их ведение, требуют существенно большего объёма эмпирических данных. В фокусе данного исследования было пространство параметров, в котором полицейские оценивают происшествия. Правовая статистика позволяет увидеть практические последствия реализа- 
ции ведомственной логики ${ }^{13}$. Однако, каким образом применение иных логик сказывается, например, на структуре раскрываемых преступлений, судить пока затруднительно.

Разведка, предпринятая в рамках данного исследования, лишь первый шаг в прояснении поставленных вопросов и отслеживании их динамики. Шаг этот сделан преимущественно на данных, касающихся Москвы, и о внешней валидности этого кейса относительно российских регионов следует говорить с осторожностью. Ещё одна проблема - достаточно высокая степень обобщения эмпирических наблюдений относительно разнообразия деятельности различных правоохранительных служб. По данным социологических исследований, под единой вывеской «полиция» работают более 36 квазипрофессиональных групп [Новикова, Шепелева 2005: 85]. Импликация выявленных логик в каждой из них требует дополнительного изучения. И эта задача представляется актуальной.

Переход издательских домов от редакторской к рыночной институциональной логике обесценил любовь к книгам и их авторам, стремление к органическому росту через создание новых книжных серий как стимул к реализации издательской деятельности. Основной ценностью стали завоёванная доля рынка и уровень получаемых прибылей, легче достигаемые за счёт переиздания хорошо продаваемой литературы [Thornton, Ocasio 1999].

Институционализировав систему оценки деятельности учёных на основании темпов публикационной активности и индексов цитируемости, современная социальная наука сделала выбор в пользу установки на бесконечную верификацию имеющихся научных результатов, существенно понизив шансы на возникновение научных открытий [Karpik 2011].

Российская полиция сегодня, похоже, близка к точке невозврата, за которой уже нельзя будет выбрать, по каким из имеющихся правилам дальше играть. Что будет, когда этот рубеж окажется пройдён? И главное — какой будет цена?

13 См., например: URL: http://crimestat.ru/opendata 
Приложение

\section{Список респондентов}

\begin{tabular}{lcc}
\hline \multicolumn{1}{c}{ Имя } & Должность и (или) звание & $\begin{array}{c}\text { Год проведения } \\
\text { интервью }\end{array}$ \\
\hline 1. Сергей & Участковый & 2010 \\
2. Иван & Сотрудник хозяйственной части, ГАИ & 2010 \\
3. Игорь & Полковник МВД, в отставке & 2010 \\
4. Валерий & Оперативник & 2011 \\
5. Арсений & Оперативник, на пенсии & 2011 \\
6. Влад & Участковый & 2011 \\
7. Вадим & Отдел МВД & 2011 \\
8. Александр & Капитан МВД & 2014 \\
9. Константин & Следователь & 2014 \\
10. Дмитрий & Майор & 2015 \\
11. Екатерина & Капитан, ГИБДД (штаб) & 2016 \\
12. Надежда & Инспектор & 2016 \\
13. Ольга & Слушатель 5-го курса МосУ МВД РФ им. В. Я. Кикотя & 2016 \\
14. Валерий & Слушатель 5-го курса МосУ МВД РФ им. В. Я. Кикотя & 2016 \\
15. Андрей & Слушатель 5-го курса МосУ МВД РФ им. В. Я. Кикотя & 2016 \\
16. Павел & Слушатель 5-го курса МосУ МВД РФ им. В. Я. Кикотя & 2016 \\
17. Ольга & Слушатель 5-го курса МосУ МВД РФ им. В. Я. Кикотя & 2016 \\
18. Елена & Слушатель 5-го курса МосУ МВД РФ им. В. Я. Кикотя & 2016 \\
19. Артем & Слушатель 5-го курса МосУ МВД РФ им. В. Я. Кикотя & 2016 \\
20. Виталий & Слушатель 5-го курса МосУ МВД РФ им. В. Я. Кикотя & 2016 \\
21. Николай & Слушатель 5-го курса МосУ МВД РФ им. В. Я. Кикотя & 2016 \\
\hline
\end{tabular}

\section{Литература}

Бергер П., Лукман Т. 1995. Социальное конструирование реальности: трактат по сочиологии знания. М.: Медиум.

Бердышева Е. 2013. «Палка о двух концах»: система оценивания эффективности деятельности правоохранительных органов АППГ + 1 в восприятии сотрудников (экономико-социологический анализ). Человек. Сообщество. Управление. 1: 127-142.

Болтански Л., Тевено Л. 2000. Социология критической способности. Журнал соџиологии и соџиильной антропологии. 3 (3): 66-83.

Борисов А., Малыгин А., Мулукаев Р. 2016. Три века российской полищии. Служение обществу. Защита Отечеству. М.: РИПОЛ классик.

Бунов Е. Г. 2011. Внутрисистемные установки оценки эффективности деятельности органов внутренних дел (по результатам социологического исследования). Криминологический журнал Байкальского университета экономики и права. 3: 71-76. 
Бурдьё П. 2005. Власть права: основы социологии юридического поля. В кн.: Бурдьё П. Социальное пространство: поля и практики. СПб.: Алетейя; 75-128.

Волков В. В. 2002. Силовое предпринимательство в России 1990-х. Экономическая сочиология. 3 (2): $18-43$.

Гадеа Ш. 2011. Социология профессий и социология профессиональных групп. В защиту изменения подхода. В кн.: Романов П., Ярская-Смирнова Е. Р. (отв. ред.) Антропология профессий, или Посторонним вход разрешён. М.: ООО «Вариант»; ЦСПГИ (Библиотека «Журнала исследований социальной политики»); 15-34.

Гладарев Б. 2011. Профессия «российский милиционер». В кн.: Романов П., Ярская-Смирнова Е. Р. (отв. ред.). Антропология профессий, или Посторонним вход разрешён. М.: ООО «Вариант»; ЦСПГИ (Библиотека «Журнала исследований социальной политики»); 113-143.

Гладарев Б. 2012. Базис без надстройки: социологические заметки о работе милиции накануне реформы 2010-2011 годов. Неволя. 28: 110-130.

Дубова А. Е., Косалс Л. Я. 2012. Включённость российских полицейских в теневую экономику. Отечественные записки. 2. 175-183.

Каллон М., Меадель С., Рабехарисоа В. 2008. Экономика качеств. Журнал социологии и сочиальной антропологии. XI (4): 59-87.

Клушин О. 3. 2007. Практика оценки эффективности деятельности правоохранительных структур зарубежных стран и возможности ее адаптации в Российской Федерации. Труды Академии управления МВД. 4. URL: http://jurnal.amvd.ru/indviewst.php?stt=74\&SID=

Коленникова O. et al. 2003. Экономическая деятельность работников милиции: масштабы, причины и последствия: В 2 ч. М.: ИСЭПН РАН.

Коленникова О., Косалс Л., Рывкина Р. 2004. Коммерционализация служебной деятельности работников милиции. Социологические исследования. 3: 73-83.

Максимова А. Е. 2013. Неформальная экономическая деятельность сотрудников полиции в трансформирующихся обществах: укоренённость в полищейской культуре. Диссертация на соискание степени кандидата социологических наук. Рукопись. НИУ ВШЭ. URL: https://www.hse.ru/sci/diss/94176917

Малыгин А. Я. (сост.) 2001. Милиция России: документы и материаль, 1917-1999 г2. Саратов: Саратовский юридический институт.

Новикова А., Шепелева О. 2005. Реформа правоохранительных органов: преодоление произвола. М.: Демос.

Панеях Э. Л., Титаев К. Д. 2011. От милиции к полиции: реформа системы оценки деятельности органов внутренних дел. СПб.: ИПП ЕУ СПб.

Радаев В. В. 2006. Что такое рынок: экономико-социологический подход. Экономическая сочиология. 7 (5): 14-27. URL: https://ecsoc.hse.ru/2006-7-5/26594533.html 
Радаев В. В. 2007. Что такое рынок: экономико-социологический подход. Экономическая социология. 8 (1): 9-26. URL: https://ecsoc.hse.ru/2007-8-1/26594593.html

Скотт Р. 2007. Конкурирующие логики в здравоохранении: профессиональная, государственная и менеджериальная. Экономическая соииология. 8(1):27-44. URL: https://ecsoc.hse.ru/2007-8-1/26594182. html

Старк Д. 2009. Гетерархия: организация диссонанса. Экономическая соииология. 10 (1): 57-89. URL: https://ecsoc.hse.ru/2009-10-1/26592321.html

Тевено Л. 2000. Какой дорогой идти? Моральная сложность «обустроенного» человека. Журнал социологии и сочииальной антропологии. 3 (3): 84-111.

Уваров И. А. 2013. Становление системы предупреждения преступности в России начала XVIII-XIX веков. Юристь-Правоведъ. 2 (57): 57-60.

Abbot A. 1993. The Sociology of Work and Occupations. Annual Review of Sociology. 19: 187-209.

Alpert G. P., Walker S. 2000. Police Accountability and Early Warning Systems: Developing Policies and Programs. Justice Research and Policy. 2 (2): 59-72.

Appadurai A. 1995. Introduction: Commodities and the Politics of Value. In: Appadurai A. (ed.). The Social Life of Things. Commodities in Cultural Perspective. Cambridge: Cambridge University Press; 3-63.

Beckert J., Aspers P. 2011. Value in Markets. In: Aspers P., Beckert J. (eds). The Worth of Goods: Valuation and Pricing in The Economy. New York: Oxford University Press; 3-40.

Comack E., Balfour G. 2004. The Power to Criminalize: Violence, Inequality and the Law. Halifax: Fernwood Publishing.

Espeland W., Stevens M. 1998. Commensuration as a Social Process. Annual Review of Sociology. 24: 312343.

Friedland R. 2012. Divine Institution: Max Weber's Value Spheres and Institutional Theory. URL: https://www. academia.edu/6713873/Divine_Institution_Max_Weber_s_Value_Spheres_and_Institutional_Theory

Friedland R., Alford R. 1991. Bringing Society Back in Symbols, Practicies and Institutional Contradictions. In: Powell W. W., DiMggio P. J. (eds). The New Institutionalism in Organizational Analysis. Chicago: University of Chicago Press; 232-263.

Freidson E. 1988. Profession of Medicine. A Study of The Sociology of Applied Knowledge. Chicago; London: The University of Chicago Press.

Gerber T., Mendelson S. E. 2008. Public Experience of Police Violence and Corruption in Contemporary Russia: A Case of Predatory Policing? Law \& Society Review. 42 (1): 1-44.

Greenwood R., Hinings C. R. 1993. Understanding Strategic Change: The Contribution of Achetypes. Academy of Management Journal. 36: 1052-1081. 
Greenwood R., Suddaby R., Hinings C. R. 2002. Theorizing Change: The Role of Professional Associations in the Transformation of Institutionalized Fields. Academy of Management Journal. 45: 58-80.

Helgesson C.-F., Muniesa F. 2013. For What It's Worth: An Introduction to Valuation Studies. Valuation Studies. 1 (1): 1-10.

Heuts F., Mol A. 2013. What Is a Good Tomato? A Case of Valuing in Practice. Valuation Studies. 1 (2): $125-146$.

Hinings C. R., Malhotra N. 2008. Change in Institutional Fields. In: Ebner A., Beck N. (eds). The Institutions of the Market. Organizations, Social Systems and Governance. Oxford: Oxford University Press; 106-128.

Humphrey C. 2002. The Unmaking of Soviet Life: Everyday Economies After Socialism. Ithaca, NY: Cornell University Press.

Hutter M., Stark D. 2015. Pragmatist Perspectives on Valuation: An Introduction. In: Antal A. B., Hutter M., Stark D. (eds). Moments of Valuation. Exploring Sites of Dissonanse. Oxford: Oxford University Press; $1-13$.

Karpik L. 2010. Valuing the Unique: The Economics of Singularity. Princeton, NJ: Princeton University Press.

Karpik L. 2011. What is the Price of Scientific Paper? In: Aspers P., Beckert J. (eds). The Worth of Goods: Valuation and Pricing in the Economy. New York: Oxford University Press; 63-85.

Kornai J. 2000. Hidden in an Envelope: Gratitude Payments to Medical Doctors in Hungary. In: DahrendorfR. G. et al. (eds). The Paradoxes of Unintended Consequences. Budapest; New York: Central European University Press, 195-214.

Kosals L. Y. 2007. Essay on Clan Capitalism in Russia. Acta Oeconomica. 57 (1): 67-85.

Maksimova A., Kosals L. Y. 2013. Russian Police Involvement in the Shadow Economy. Russian Politics and Law. 4: 48-58.

Mennicken A., Sjögren E. 2015. Valuation and Calculation at the Margins. Valuation Studies. 3 (1): 1-7.

O’Connor T. R. 2005. Police Deviance and Ethics. Criminal Justice. URL: http://www.faculty.ncwc.edu/ toconnor/205/205lect11.htm.

Perry F. 2001. Repairing Broken Windows - Police Corruption. FBI Law Enforcement Bulletin. 70 (2): 2327.

Punch M. 2003. Rotten Orchards: «Pestilence», Police Misconduct and System Failure. Policing and Society. 13 (2): 171-196.

Shelley L. 1996. Policing Soviet Society. London; New York: Routledge.

Stark D. 2009. The Sense of Dissonance: Accounts of Worth in Economic Life. Princeton: Princeton University Press. 
Stark D. 2011. What's Valuable? In: Aspers P., Beckert J. (eds). The Worth of Goods: Valuation and Pricing in the Economy. New York: Oxford University Press; 319-338.

Thornton P. H., Ocasio W. 1999. Institutional Logics and the Historical Contingency of Power in Organizations: Executive Succession in the Higher Education Publishing Industry, 1958-1990. The American Journal of Sociology. 105 (3): 801-843.

Thornton P. H., Ocasio W., Lounsbury M. 2012. The Institutional Logics Perspective. A New Approach to Culture, Structure and Process. Oxford: Oxford University Press.

Wells W. 2009. Performance Appraisal Systems. In: Maguire E., Wells W. (eds). Implementing Community Policing: Lessons from 12 Agencies. US Department of Justice. URL: http://ric-zai-inc.com/Publications/ cops-w0746-pub.pdf

Xu J. 2013. Police Accountability and the Commodification of Policing in China. A Study of Police/Business Posters in Guangzhou. British Journal of Criminology. 53 (6): 1093-1117. 


\section{Elena Berdysheva}

\section{Varying Worth of Crimes in the Eyes of Policemen in Russia}

\author{
BERDYSHEVA, Elena - \\ Candidate of Sciences in \\ Sociology; Senior Research \\ Fellow, Laboratory for Studies \\ in Economic Sociology, National \\ Research University Higher \\ School of Economics. Address: \\ 20 Myasnitskaya str., Moscow, \\ 101000, Russian Federation.
}

\section{Email: eberdysheva@hse.ru}

\begin{abstract}
The article demonstrates that crimes that come to the attention of the criminal police have varying worth in the eyes of Russian policemen and, consequently, attract unequal efforts. The worth of crimes is closely related to the criteria for evaluation of police performance. The data derived from 12 in-depth interviews with Russian police officers, nine indepth interviews with senior students of Moscow University of Russian Interior Ministry who are undergoing practice within police departments, and online discussions within the police community show that policemen in Russia made their practical decisions while balancing between multiple orders of worth.
\end{abstract}

The theoretical framework of data interpretation is represented by symbiosis theories of valuations and the institutional logics approach. Operationalized as a set of cultural rules and expectations defining legitimate grounds for assessing and determining what rational behavior in a given organizational context really is, the concept of institutional logics stresses the interrelations between value-oriented and material dimensions of social action but allows one to stress the hierarchy and constant competition between various orders of worth in an organization. Four institutional logics — state, clan, quasi-market, and professional — are empirically identified. Each of them brings its own order of worth to the police organizational environment.

Crimes in the eyes of the police always have a price - expressed in either "checkmarks," points of recognition by the boss or colleagues, or money. The data suggest that, despite the hierarchy between the orders of (crimes') worth within the police system as a whole, in each case, institutional logics and criteria of worth related to them compete with each other. Depending on the characteristics of the criminal case and the situation in the police department at a given moment, the competition between various orders of worth is resolved by policemen in different ways. The results of the study shed light on the functioning of police discretion and help to accentuate the dysfunctional side of police reform in Russia.

Keywords: orders of worth; justice; professionalism; corruption; policing reform in Russia; performance appraisal system.

\section{Acknowledgements}

The article is based on data from the project "Informal Economic Activity of Police in Transforming Countries and the Problems of Population Safety (the Cases of Russia, Bulgaria, Kazakhstan, and Latvia)" being realized within the framework of the Academic Fund Program at the National Research University Higher School of Economics (HSE) in 2016.

The author wishes to thank professor Leonid Kosals (HSE) and the reviewers for all their comments and suggestions. 


\section{References}

Abbot A. (1993) The Sociology of Work and Occupations. Annual Review of Sociology, no 19, pp. 187-209.

Alpert G. P., Walker S. (2000) Police Accountability and Early Warning Systems: Developing Policies and Programs. Justice Research and Policy, vol. 2, no 2, pp. 59-72.

Appadurai A. (1995) Introduction: Commodities and the Politics of Value. The Social Life of Things. Commodities in Cultural Perspective (ed. A. Appadurai), Cambridge: Cambridge University Press, pp. 3-63.

Beckert J., Aspers P. (2011) Value in Markets. The Worth of Goods: Valuation and Pricing in the Economy (eds. P. Aspers, J. Beckert), New York: Oxford University Press, pp. 3-40.

Berdysheva E. (2013). "Palka o dvukh kontsakh": sistema otsenivaniya effektivnosti deyatel'nosti pravookhranitel'nykh organov APPG $+1 \mathrm{v}$ vospriyatii sotrudnikov (ekonomiko-sotsiologicheskiy analiz) [The Stick of Two Tails: Police Performance Appraisal System in Perception of Policemen (EconomicSociological Analysis)]. Chelovek. Soobshchestvo. Upravlenie. no 1, pp. 127-142 (in Russian).

Berger P., Luckmann T. (1995) Sotsial'noe konstruirovanie real'nosti: traktat po sotsiologii znaniya [The Social Construction of Reality: A Treatise in the Sociology of Knowledge], Moscow: Medium (in Russian).

Boltanski L., Thevenot L. (2000) Sotsiologiya kriticheskoy sposobnosti [The Sociology of Critical Capacity]. Zhurnal sotsiologii i sotsial'noy antropologii, vol. 3, no 3, pp. 66-83 (in Russian).

Borisov A., Malygin A., Mulukaev R. (2016) Tri veka rossiyskoy politsii. Sluzhenie obshchestvu. Zashchita otechestvu [Three Centuries of Russian Police. Serving to Society. Defending the Motherland], Moscow: Ripol Classik Publishung House (in Russian).

Bourdieu P. (2005) Vlast' prava: osnovy sotsiologii yuridicheskogo polya [The Force of Law: Toward a Sociology of the Juridical Field]. Bourdieu P. Sotsial'noe prostranstvo: polya i praktiki [Social Space: Fields and Practices] (ed. N. A. Shmatko), St. Petersburg: Aleteya, pp. 75-128 (in Russian).

Bunov E. G. (2011) Vnutrisistemnye ustanovki otsenki effektivnosti deyatel'nosti organov vnutrennikh del (po rezul'tatam sotsiologicheskogo issledovaniya) [Inner Performance Appraisal in the Body of Inner Affairs: The Results of Sociological Study]. Kriminologicheskiy zhurnal Baykal'skogo universiteta ekonomiki i prava, no 3, pp. 71-76 (in Russian).

Callon M., Meadel C., Rabeharisoa V. (2002) Ekonomika kachestv [The Economy of Qualities]. Zhurnal sotsiologi i sotsial'noy antropologii, vol. XI, no 4, pp. 59-87 (in Russian).

Comack E., Balfour G. (2004) The Power to Criminalize: Violence, Inequality and the Law, Halifax: Fernwood Publishing.

Dubova A., Kosals L. (2012) Vklyuchennost' rossiyskikh politseyskikh v tenevuyu ekonomiku [Engagement of Russian Policemen in the Shadow Economy]. Otechestvennye zapiski, no 2, pp. 175-183 (in Russian).

Espeland W., Stevens M. (1998) Commensuration as a Social Process. Annual Review of Sociology, no 24, pp. 312-343. 
Freidson E. (1988). Profession of Medicine. A Study of the Sociology of Applied Knowledge, Chicago: London: The University of Chicago Press.

Friedland R., Alford R. (1991) Bringing Society Back in Symbols, Practices and Institutional Contradictions. The New Institutionalism in Organizational Analysis (eds. W. W. Powell, P. J. DiMaggio), Chicago: University of Chicago Press, pp. 232-263.

Friedland R. (2012) Divine Institution: Max Weber's Value Spheres and Institutional Theory. Available at: https://www.academia.edu/6713873/Divine_Institution_Max_Weber_s_Value_Spheres_and_Institutional_Theory (accessed 9 September 2016).

Gadea S. (2011). Sotsiologiya professiy i sotsiologiya professional'nykh grupp. V zashchitu izmeneniya podkhoda [Sociology of Professions and Sociology of Professional Groups. In Defense of Changes of the Approach]. Antropologiya professiy, ili Postoronnim vkhod razreshen [Anthropology of the Profession, or No Entry] (eds. P. Romanov, E. Yarskaya-Smirnova), Moscow: OOO "Variant”; CSPGI (Biblioteka "Zhurnala issledovaniyy sotsial'noy politiki”), pp. 15-34 (in Russian).

Gerber T., Mendelson S. E. (2008) Public Experience of Police Violence and Corruption in Contemporary Russia: A Case of Predatory Policing? Law \& Society Review, vol. 42, no 1, pp. 1-44.

Gladarev B. (2011) Professiya "rossiyskiy militsioner" [Russian Militiaman as a Profession]. Antropologiya professiy, ili Postoronnim vkhod razreshen [Anthropology of the Profession, or No Entry] (eds. P. Romanov, E. Yarskaya-Smirnova), Moscow: OOO "Variant"; CSPGI (Biblioteka "Zhurnala issledovaniyj sotsial'noy politiki”), pp. 113-143 (in Russian).

Gladarev B. (2012) Bazis bez nadstroyki: sotsiologicheskie zametki o rabote militsii nakanune reformy 2010-2011 godov [Basis without Superstructure: Sociological Essay about Militia before the 2010-2011 Reform]. Nevolya, no 28, pp. 110-130 (in Russian).

Greenwood R., Hinings C. R. (1993) Understanding Strategic Change: the Contribution of Achetypes. Academy of Management Journal, vol. 36, pp. 1052-1081.

Greenwood R., Suddaby R., Hinings C. R. (2002) Theorizing Change: The Role of Professional Associations in the Transformation of Institutionalized Fields. Academy of Management Journal, no 45, pp. 58-80.

Helgesson C.-F., Muniesa F. (2013) For What It's Worth: An Introduction to Valuation Studies. Valuation Studies, vol. 1, no 1, pp. 1-10.

Heuts F., Mol A. (2013) What is a Good Tomato? A Case of Valuing in Practice. Valuation Studies, vol. 1, no 2, pp. 125-146.

Hinings C. R., Malhotra N. (2008) Change in Institutional Fields. The Institutions of the Market. Organizations, Social systems and Governance (eds. A. Ebner, N. Beck), Oxford: Oxford University Press, pp. 106-128.

Humphrey C. (2002) The Unmaking of Soviet Life: Everyday Economies After Socialism, Ithaca, NY: Cornell University Press.

Hutter M., Stark D. (2015) Pragmatist Perspectives on Valuation: An Introduction. Moments of Valuation. Exploring Sites of Dissonanse (eds. A. B. Antal, M. Hutter, D. Stark), Oxford: Oxford University Press, pp. 1-14. 
Karpik L. (2010) Valuing the Unique: The Economics of Singularity. Princeton, NJ: Princeton University Press.

Karpik L. (2011) What is the Price of Scientific Paper? The Worth of Goods: Valuation and Pricing in the Economy (eds. P. Aspers, J. Beckert), New York: Oxford University Press, pp. 63-85.

Klushin O. Z. (2007) Praktika ocenki ehffektivnosti deyatel'nosti pravoohranitel'nyh struktur zarubezhnyh stran i vozmozhnosti ee adaptacii v Rossijskoj Federacii [Practice of Police Performance Appraisal in Different Countries and The Potential of Adaptation Them in Russian Federation]. Trudy Akademii Upravleniya MVD. 4. Available at: http://jurnal.amvd.ru/indviewst.php?stt=74\&SID= (accessed 9 September 2016) (in Russian).

Kolennikova O., Kosals L., Ryvkina R. (2004). Kommertsionalizatsiya sluzhebnoy deyatel'nosti rabotnikov militsii [Commercialization of Militia Work]. Sociologicheskie issledovaniya, no 3, pp. 73-83. (in Russian).

Kolennikova O., Kosals L., Ryvkina R., Simagin Y. (2003) Ekonomicheskaya deyatel'nost' rabotnikov militsii: masshtaby, prichiny i posledstviya [Economic Activity of Militia: Size, Reasons and Consequences]: 2 parts, Moscow: ISEHPN RAN (in Russian).

Kornai J. (2000). Hidden in an Envelope: Gratitude Payments to Medical Doctors in Hungary. The Paradoxes of Unintended Consequenses (eds. R. H. Dahrendorf, lord, E. Yehuda, N. Aryeh, W. Newton-Smith, I. Rév), Budapest; New York: Central European University Press, pp. 195-214.

Kosals L. Y. (2007) Essay on Clan Capitalism in Russia. Acta Oeconomica, vol. 57, no 1, pp. 67-85.

Maksimova A. E. (2013) Neformal'naya ekonomicheskaya deyatel'nost'sotrudnikov politsii v transformiruyushchihsya obshchestvakh: ukorenennost'v politseyskoy kul'ture [Informal Economic Activity in Police in Transitional Societies: Embededdness in Police Culture]. Dissertatsiya na soiskanie stepeni kandidata sotsiologicheskikh nauk. Rukopis'. HSE. Available at: https://www.hse.ru/sci/diss/94176917 (accessed 9 September 2016) (in Russian).

Maksimova A., Kosals L. Y. (2013) Russian Police Involvement in the Shadow Economy. Russian Politics and Law, no 4, pp. 48-58.

Malygin A. Y. (2001) Militsiya Rossii: dokumenty i materially, 1917--1999 gg. [Militia in Russia: Documents and Materials, 1917-1999] (collected A. Y. Malygin), Saratov: Saratovsky Uridichesky Institute (in Russian).

Mennicken A., Sjögren E. (2015) Valuation and Calculation at the Margins. Valuation Studies, vol. 3, no 1, pp. $1-7$.

Novikova A., Shepeleva O. (2005) Reforma pravoohranitel'nykh organov: preodolenie proizvola [Reform of Law Enforcement Bodies: Overcoming the Abuse of Power], Moscow: Demos (in Russian).

O’Connor T. R. (2005) Police Deviance and Ethics. Criminal Justice. Available at: http://www.faculty.ncwc. edu/toconnor/205/205lect11.htm (accessed 9 September 2016). 
Paneyakh E., Titaev K. (2011) Ot militsii k politsii: reforma sistemy otsenki deyatel'nosti organov vnutrennikh del [From Militia to Police: Reform of The Evaluation System of the Activities of Internal Affairs Bodies], St. Petersburg: IPP EU SPb (in Russian).

Perry F. (2001) Repairing Broken Windows - Police Corruption, FBI Law Enforcement Bulletin, vol. 70, no 2, pp. 23-27.

Punch M. (2003) Rotten Orchards: "Pestilence”, Police Misconduct and System Failure. Policing and Society, vol. 13, no 2, pp. 171-196.

Radaev V. (2006) Chto takoe rynok: ekonomiko-sotsiologicheskiy podkhod [What Market Is? Economic Sociology Approach]. Journal of Economic Sociology = Ekonomicheskaya sotsiologiya, vol. 7, no 5, pp. 1427. Available at: https://ecsoc.hse.ru/2006-7-5/26594533.html (accessed 9 September 2016) (in Russian).

Radaev V. (2007) Chto takoe rynok: ekonomiko-sotsiologicheskiy podkhod [What Market Is? Economic Sociology Approach]. Journal of Economic Sociology = Ekonomicheskaya sotsiologiya, vol. 8, no 1, pp. 9-26. Available at: https://ecsoc.hse.ru/2007-8-1/26594593.html (accessed 9 September 2016) (in Russian).

Scott R. W. (2007) Konkuriruyushchie logiki v zdravookhranenii: professional'naya, gosudarstvennaya i menedzherial'naya [Competing Logics in Healthcare: Professional, State and Managerial]. Journal of Economic Sociology = Ekonomicheskaya sotsiologiya, vol. 8, no 1, pp. 27-44. Available at: https://ecsoc. hse.ru/2007-8-1/26594182.html (accessed 9 September 2016) (in Russian).

Shelley L. (1996) Policing Soviet Society, London; NewYork: Routledge.

Stark D. (2009a) Geterarkhiya: organizatsiya dissonansa [Heterarchies: Organization of Dissonance]. Journal of Economic Sociology = Ekonomicheskaya sotsiologiya. vol. 10, no 1, pp. 57-89. Available at: https:// ecsoc.hse.ru/2009-10-1/26592321.html (accessed 9 September 2016) (in Russian).

Stark D. (2009b) The Sense of Dissonance: Accounts of Worth in Economic Life, Princeton: Princeton University Press.

Stark D. (2011). What's Valuable? Aspers P., Beckert J. (eds). The Worth of Goods: Valuation and Pricing in the Economy. New York: Oxford University Press, pp. 319-338.

Thevenot L (2000) Kakoy dorogoy idti? Moral'naya slozhnost' "obustroennogo" cheloveka [Which Road to Follow? The Moral Complexity of an "Equipped" Humanity]. Zhurnal sotsiologii i sotsial'noy antropologii, vol. 3, no 3, pp. 84-111 (in Russian).

Thornton P. H., Ocasio W. (1999) Institutional Logics and the Historical Contingency of Power in Organizations: Executive Succession in the Higher Education Publishing Industry, 1958-1990. The American Journal of Sociology, vol. 105, no 3, pp. 801-843.

Thornton P. H., Ocasio W., Lounsbury M. (2012) The Institutional Logics Perspective. A New Approach to Culture, Structure and Process, Oxford: Oxford University Press.

Uvarov I. A. (2013) Stanovlenie sistemy preduprezhdeniya prestupnosti v Rossii nachala XVIII-XIX vekov [The Establishment of the System of Crime Prevention in Russia at the beginning of XVIII-XIX Centuries]. Yurist-Pravoved, vol. 2, no 57, pp. 57-60 (in Russian). 
Wells W. (2009). Performance appraisal systems. Implementing community policing: Lessons from 12 Agencies (eds. E. Maguire, W. Wells), US Department of Justice. Available at: http://ric-zai-inc.com/Publications/cops-w0746-pub.pdf (accessed 9 September 2016)

Xu J. (2013). Police Accountability and the Commodification of Policing in China. A Study of Police/Business Posters in Guangzhou. British Journal of Criminology, vol. 53, no 6, pp. 1093-1117.

Received: April 15, 2016.

Citation: Berdysheva E. (2016) Differentsiatsiya "privlekatel'nosti” pravonarusheny v vospriyatii rossiyskikh politseyskikh [Varying Worth of Crimes in the Eyes of Policemen in Russia]. Journal of Economic Sociology = Ekonomicheskaya sotsiologiya, vol. 17, no 4, pp. 15-52. Available at: https://ecsoc.hse.ru/2016-17-4. html (in Russian). 


\section{НОВЫЕ ПЕРЕВОДЫ}

\section{М. де Ваан, Б. Ведреш, Д. Старк \\ Игры-события: топология креативности ${ }^{1}$}

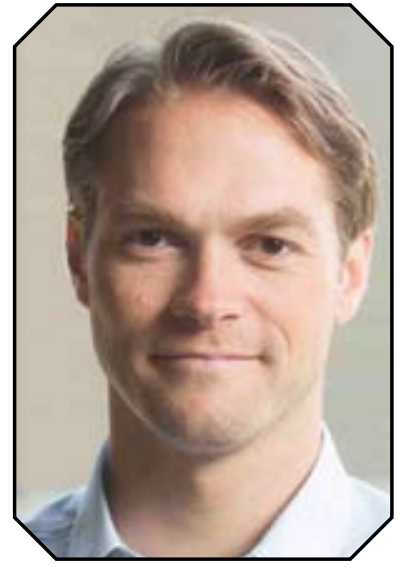

ДЕ ВАAН Матейс (Mathijs de Vaan) - доцент в области менеджмента организации Школы бизнеса им. Уолтера Хааса Университета Калифорнии в Бёркли. Адрес: США, штат Калифорнии, 94720-1900, г. Бёркли.

Email: mdevaan@haas. berkeley.edu

Перевод с английского Александра Куракина

Источник: Vaan M. de, Vedres B., Stark D. 2015. Game Changer: The Topo-logy of Creativity. American Journal of Sociology. 120 (4) (January): 1144-1194.

Публикуется с разрешения American Journal of Sociology.
Авторы статьи ищут структурные основания успеха в коллективных проектах. В данной работе они продолжают использовать ранее разработанные ими понятия «структурные складки» и «продуктивное напряжение», однако делают шаг вперёд в своём подходе, не ограничиваясь рассмотрением сочиальной структуры, а включив в анализ когнитивные переменные. Статья посвящена исследованию сочиологических факторов, объясняющих, почему творческим командам удаётся создавать игры-события культурные продукты, которые не только стоят особняком как самобытные, но и признаны критиками выдающимися. Авторы выстраивают свою работу на понятии «структурные складки» как сетевом свойстве сплочённой группы, отдельные члены которой одновременно являются членами другой сплочённой группь. Гипотеза состояла в том, что эффект воздействия структурных складок на вероятность создания игры-события будет особенно сильным в том случае, когда пересекающиеся группы когнитивно разнородньл. Измерив социальную дистаничию независимо от когнитивной, а самобытность - независимо от признания критиков, авторы тестируют свои гипотезы о структурных складках и когнитивном разнообразии на основе анализа команд, собиравшихся для производства 12422 видеоигр, а также 139727 карьер разработчиков видеоигр. Когда структурные складки дополнены когнитивным разрывом, они способны направлять и мобилизовать продуктивное напряжение правил, ролей и кодов, которые способствуют успешной инновачии. Сетевые связи служат не только трубами и призмами, но и источником инструментов и напряжения.

Ключевые слова: креативность; структурная складка; продуктивное напряжение; социальные сети; сплочённость группы; когнитивное разнообразие; инновации.

\footnotetext{
Исследование для данной статьи было поддержано грантом Национального научного фонда (SES-1123807). Вклад соавторов одинаков. Мы меняем порядок фамилий соавторов в разных публикациях, написанных на основе нашего проекта по социальным сетям. За комментарии, критику и предложения по этим публикациям мы признательны Шамусу Хану (Shamus Khan), Джанлуке Карнабучи (Gianluca Carnabuci), Маттео Прато (Matteo Prato), Елене Эспозито (Elena Esposito), Коэну Френкену (Koen Frenken), Моник Жирар (Monique Girard), Жерно Грабхеру (Gernot Grabher), Майклу Хаттеру (Michael Hutter), Франческо Маццучелли (Francesco Mazzucchelli), Деймону Дж. Филипсу (Damon J. Phillips), а также участникам серии семинаров «Организация на основе совместной работы и цифровые экосистемы» (Collaborative Organization and Digital Ecologies, CODES) в Центре организационных инноваций Колумбийского университета. Мы признательны Институту Европейского университета (European University Institute) во Флоренции и Институту перспективных исследований (Institute for Advanced Study) в Нидерландах за годичную поддержку Д. Старка при подготовке рукописи данной работы.
} 


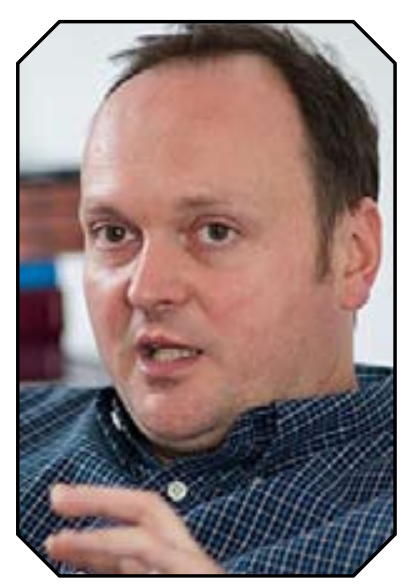

ВЕДРЕШ Балаш (Vedres, Balazs) - професcop факультета социологии и социальной антропологии, директор Центра по изучению сетей (Centre for Network Science) Центрально-Европейского университета. Адрес: Венгрия, 1051, г. Будапешт, ул. Надор, д. 9.

\section{Email: vedresb@ceu.hu}

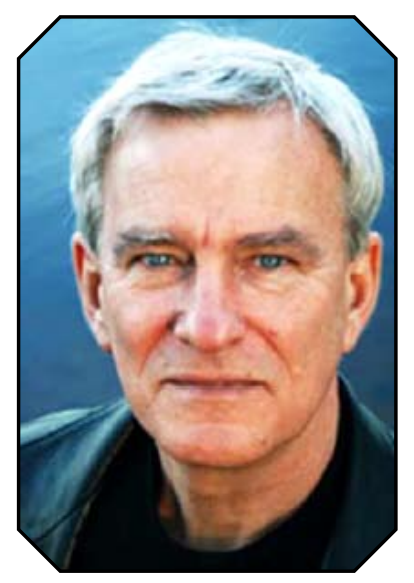

СТАРК Дэвид (Stark, David) - профрeccop социологии и международных отношений, декан факультета социологии Университета Колумбия. Адрес: США, 10027, г. НьюЙорк, на пересечении 116-й улицы и Бродвея.

Email: dcs36@columbia.edu

\section{Введение}

Чем можно объяснить творческий успех, когда инновация производится командой? В частности, каковы социологические факторы, объясняющие, почему некоторые коллективы способны создать не только новый, но и признанный культурный продукт? В погоне за новизной творческая команда рискует разработать продукт, который не будет соответствовать вкусам критиков и потребителей. Разница между «захватывающим» и «странным», будь она большой или же тонкой, как лезвие бритвы, может оказаться тем, что отделяет хит от провала [DiMaggio 1997; Lampel, Lant, Shamsie 2000; Hutter 2011]. Новизна не является ни достаточным, ни необходимым условием успеха, ибо иногда потребители и критики вознаграждают за конформизм. Чтобы изменить привычные правила игры в творческом пространстве, команда должна создать такой продукт, который был бы не только уникальным, но и признанным. Он должен быть заметным и замеченным.

Согласно сетевым исследованиям, социальная структура является важным фактором успеха команды. Одни при этом указывают на уровни сплочённости, утверждая, что избыточные связи создают доверие и улучшают коммуникацию, чем способствуют внедрению разработки [Reagans, McEvily 2003; Obstfeld 2005]. Другие утверждают, что сплочённость может быть чрезмерной, и показывают нелинейную связь между нею и результативностью [Berman, Down, Hill 2002; Uzzi, Spiro 2005]. Третьи демонстрируют важность посредничества, которое порой противостоит сплочённости [Burt 1995], а порой согласуется с ней [Burt 2005; Obstfeld 2005]. Некоторые исследователи считают, что посредники распространяют идеи через структурные пустоты [Burt 1995] либо сами придумывают хорошие идеи [Burt 2004]. Есть и те, кто выступает за иную концепцию посредничества как интегративного труда, создающего новые идеи через объединение членов команды, которые раньше были не связаны друг с другом [Lingo, O’Mahony 2010].

Мы опираемся на эти работы, а также на собственные исследования [Vedres, Stark 2010], которые показывают, что сетевые характеристики командного производства не ограничиваются посредничеством и сплочённостью. И вновь обращаемся к структурныл складкам - сетевому свойству сплочённой группы, часть членов которой являются одновременно и членами другой сплочённой группы. Эти рассуждения восходят к идее Зиммеля, что индивидуальность может быть результатом уникального пересечения сетевых кругов [Simmel 1955]. Такие перекрывающиеся структуры являются также и источником трансформационных сил [Sewell 1992]. Как выяснилось, структурные складки вносят существенный вклад в повышение результативности венгерских бизнес-групп, поэтому мы пришли к выводу, что успех проистекает из сочетания сходств и различий, когда разнородные элементы соединяются в непростое единство, способное породить что-то новое именно потому, что содержат напряжение [Vedres, Stark 2010]. Tем не менее собранные нами данные не позволяли проверить этот объясняющий механизм в действии. Это делается в данной статье. 
Рассмотрим для начала новые работы в области социологии культуры. Критической точкой в этом поле является предложенное Энн Свидлер переопределение понятия культуры [Swidler 1986], понимаемой не как интернализированные верования, нормы и разделяемые ценности, а как «ресурсы, которые могут быть стратегически использованы» [DiMaggio 1997: 265]. Утверждение Свидлер породило волну новых исследований, рассматривающих культуру не столько как набор правил, сколько как набор навыков [Lamont 1992; Zerubavel 1997; Ganz 2000; Alexander 2004]. Правда, сама Свидлер позднее сетовала, что большинство из этих работ видели в индивиде актора, который выбирает навыки из культуры, как из ящика с инструментами [Swidler 2008] (см. также дискуссию: [Jerolmack, Khan 2014]). Исключением является исследование Н. Элиасоф и П. Лихтермана, которые отказались от такого индивидуализма в пользу «групповых стилей» [Eliasoph, Lichterman 2003]. Их концепция «культуры во взаимодействии» была основана на наблюдениях того, как груnпы координируют сами себя [Eliasoph, Lichterman 2003: 740].

Мы придерживаемся этой концепции культуры, переключая внимание от индивидуального использования существующих инструментов на сами навыки, которые развиваются в ходе непрерывного процесса человеческих отношений. Этот насквозь отношенческий подход к культуре вызывает несколько вопросов, которые ранее не ставились. Во-первых, соглашаясь с Элиасоф и Лихтерманом в том, что культурные стили являются характеристикой групп, мы спрашиваем: «Откуда берутся групповые стили?». Во-вторых, принимая концепцию «культуры во взаимодействии», мы задаёмся вопросом: «Что происходит, когда группы с разными культурными стилями вступают во взаимодействие?». Это означает, что мы принимаем реалистичный подход, признавая, что во многих, если не в большинстве, явлений, представляющих социологический интерес, скорее всего, задействовано более одного группового стиля. Наше исследование затрагивает случаи стилистического разнообразия, и мы особенно заинтересованы в изучении последствий этого для творческого успеха, когда взаимодействуют группы с очень разными (когнитивными и (или) культурными) стилями.

Таким образом, наше исследование является частью нового движения в социологии [Pachucki, Brieger 2010; DiMaggio 2011], которое можно одинаково хорошо описать либо как привнесение аналитических инструментов сетевого моделирования в поле социологии культуры, либо как привнесение аналитических инструментов социологии культуры в поле сетевого анализа. Мы стремимся разработать культурно-сетевой анализ, который был бы одинаково чувствителен как к культурно-когнитивным, так и к групповым структурам.

Групповые и когнитивные структуры определяются нами через карьеры членов команды. За свою карьеру люди, работающие в проектно-организованных индустриях, переходят от одного проекта к другому [Peterson, Berger 1971; Caves 2002; Grabher 2002, 2004]. Что и кого они знают, во многом зависит от траектории движения через это проектное пространство. Рассматриваемое сквозь призму какоголибо проекта, членство в различных командах и их пересборка в рамках отдельного проекта приводят к воздействию со стороны как отдельных методов производства, так и накопления социальных отношений. Иными словами, культурно-когнитивная структура данной команды (например, относительная однородность или разнообразие когнитивных стилей) формируется историей такого воздействия на её членов в предыдущих командах. Похожим образом её социальная структура (взаимоотношение среди составляющих её сообществ) выкристаллизовывается в ходе истории сотрудничества её членов в предыдущих командах.

Следовательно, участие в предыдущих проектах создаёт знание (то, что вы знаете) и группы (те, кого вы знаете). Множество групп на основании того, кто с кем работал в прошлом, могут войти в состав отдельной команды. Группы могут пересекаться или нет. Также в этой команде могут быть члены, когнитивно близкие или далёкие, схожие или различные, в зависимости от того, в какой стилистике им 
приходилось работать в прошлом. Мы прослеживаем эти стилистические и социальные воздействия, чтобы показать, как они создают социокогнитивные топологии, которые объясняют творческий успех с помощью культурных оснований.

Наша главная гипотеза состоит в том, что влияние структурных складок на изобретательность и творческий успех, меняющий правила игры, особенно сильно в случае, когда пересекающиеся группы когнитивно далеки друг от друга. Иными словами, команды имеют наибольшие шансы добиться творческого успеха, если их когнитивно разнородные группы имеют точки пересечения. Развивая рассуждения, приводящие к этой гипотезе, мы опираемся на работы по топологии знания в области семиотики [Есо 1990; Lotman 1990; 2009]. Образование складок не устраняет и не преодолевает дистанцию. Оно не создаёт гармонии. Вместо этого оно направляет и мобилизует продуктивное трение правил, ролей и кодов, что ведёт к успешной инновации.

В первой части статьи развивается наша аргументация по поводу сетевой структуры инноваций в ситуации, когда творческой единицей выступают команды. Во-первых, мы утверждаем, что команды состоят из сплочённых групп, образовавшихся в результате предыдущей совместной деятельности. Во-вторых, мы показываем, что сетевой анализ должен содержать не только социальные, но и когнитивные структуры, испытавшие ранее воздействие со стороны стилистических кодов. В-третьих, под влиянием семиотических работ по топологии знания мы одновременно используем понятия «структурные складки» и «когнитивное разнообразие», утверждая, что сетевые структуры пересекающихся сплочённых групп способствуют творческому успеху, когда они содержат высокий уровень когнитивного разнообразия. Это значит, что структурные складки способствуют творческому успеху, когда они охватывают разнообразные культурные элементы.

Для проверки своей гипотезы мы выбрали сферу разработки видеоигр. Во второй части статьи мы разрабатываем нашу аналитическую стратегию, начиная с описания собранных данных по 12422 видеоиграм, которые были произведены с момента зарождения индустрии, в 1979-2009 гг. В дополнение к фиксации стилистических элементов каждой игры был составлен полный список членов команд разработчиков. Присвоив уникальный идентификационный номер (ID) каждому из 139727 человек, мы смогли для всех команд в индустрии видеоигр реконструировать полный карьерный путь всех их членов.

Наши зависимые и независимые переменные созданы с таким прицелом, чтобы ответить на вопросы, находящиеся на пересечении сетевого анализа и социологии культуры. Для проверки предположений о связи между структурными складками и когнитивным разнообразием необходимо обладать концептами и методами, позволяющими понять и измерить когнитивную дистанцию независимо от характеристик социальной структуры. Когнитивная и социальная дистанции вовсе не обязательно совпадают. Например, нам не следует считать, что удалённые социальные связи являются хорошим индикатором (proxy) для когнитивной дистанции. Создав аналитические инструменты для непосредственного измерения когнитивной дистанции, мы сможем наблюдать такие ситуации, когда две структуры примерно одинаковой социальной дистанции (измеряемой уровнями сплочённости или удалёнными мостами) могут находиться на разных уровнях когнитивной дистанции. Такие индикаторы, следовательно, позволят нам проверить независимое и совместное влияние когнитивного разнообразия и социальной структуры при предсказании успешных инноваций.

Проверка предположений о факторах, объясняющих творческий успех, также требует решения проблемы о необязательном совпадении новизны и признания. В исследованиях нередко либо допущение, что успешный продукт должен быть инновационным (в качестве примера такого ошибочного допущения см.: [Vedres, Stark 2010]), либо допущение, что раз продукт был инновационным, то он должен иметь 
успех. В данной статье, подобно тому, как мы разрабатываем методы для различения социальной и когнитивной дистанций, совершенствуются аналитические инструменты для концептуализации и измерения инновационности, независимой от степени признания, что позволяет нам построить третью зависимую переменную - комбинацию инновационности и признания, отражающую и изменения правил игры.

В заключительном разделе представлены результаты. С помощью новых техник компьютерной симуляции мы показываем, что группы, сформированные на основе предыдущего опыта совместной работы в командах, являются по-настоящему неординарными социальными структурами. Такие группы способны не только выстраивать социальные связи; их члены также обладают схожими культурными и стилистическими элементами, что позволяет группе поддерживать «групповой стиль». При переходе к следующим проектам вклад каждого в инновационную деятельность команды наиболее значителен, когда между членами группы есть структурные складки, а стили когнитивно различны. Иными словами, самобытные и признанные продукты создаются тогда, когда гетерогенные групповые стили пересекаются на социальном уровне.

\section{Социокогнитивная топология креативности}

\section{Команда, состоящая из групп}

В спорте, бизнесе, науке или искусстве командная работа является искусным представлением, которое требует умелых исполнителей, обладающих глубоким знанием предмета и высоким мастерством. Но подобные творческие начинания нуждаются в нечто большем, нежели просто состав блестящих исполнителей [Becker 1974]. Для успеха нужно играть слаженно, как команде. А для такой игры имеет значение, взаимодействовал ли этот состав раньше.

История совместной работы повышает результаты за счёт увеличения некодифицированного знания метазнания, которое исследователи связывают с «памятью взаимодействия» [Wegner 1995; Carley 2001]. В отличие от технического или художественного, метазнание включает, например, владение нюансами и тонкостями того, как чей-то приятель интерпретирует сценарий, играет в спортивную игру или пишет программный код для видеоигры [De Nooy 2003]. Для достижения спонтанной синхронности действий успешной команде требуется способность распознавания шаблонов на коллективном уровне. Лишь совместный опыт работы позволяет участникам создавать распознавательные схемы, необходимые для мгновенной, незамедлительной взаимной адаптации [Berman, Downs, Hill 2002: 16].

Опыт совместной работы улучшает координацию благодаря возникновению разделяемых всеми неформальных правил и неявных инструкций (implicit protocols) к тому, как следует делать свою работу. Такие неформальные инструкции особенно важны в проектной деятельности, где сжатые сроки означают, что на разработку или распространение формальных организационных процедур просто нет времени [Grabher 2002; 2004]. Помимо того что эти нормы позволяют предугадывать поведение партнёров по команде, они создают впечатление, что «вот именно так мы делаем свою работу». Ощущаемое всеми присутствие этого «мы» необязательно нужно озвучивать. Проектная деятельность, для которой характерны сжатые сроки, интенсивный рабочий ритм и частое междисциплинарное сотрудничество, создаёт особо прочные командные узы [Ibert, Schmidt 2012]. Совместный труд рождает сообщество. В совместном труде проявляется то, как мы делаем свою работу.

Итак, работать вместе с другими значит изучить, как они работают; работать совместно значит также разработать неписаные нормы и неформальные правила того, как работать; разделять это неявное знание ролей и кодов с двумя людьми или более значит обладать чувством общности. Команды поэтому 
составлены не просто из индивидов или пар индивидов, а из групn, основанных на общем опыте совместного труда.

Так, первый рабочий день в новом проекте собирает не только людей, но и группы. Если вам когда-либо приходилось участвовать в крупных исследовательских проектах, обслуживать специальную рабочую группу на предприятии или посещать специальные курсы (workshop), вам должен быть знаком обмен взглядами на первой встрече новой команды между узнающими друг друга её членами, которые раньше уже работали вместе. Вероятность того, что все со всеми уже успели поработать, мала, поэтому те члены команды, которые лучше знакомы с особенностями друг друга, скорее всего, и обратятся друг к другу в трудную минуту, будь то в начале проекта или позднее, в периоды наибольшей нервотрёпки, когда поджимают сроки. Таким образом, схемы взаимодействия, построенные на опыте совместной работы, могут вполне успешно переноситься в новый проект [Stark 2009].

Мы считаем, что композиция команды, занимающейся творческой деятельностью, всё более становится задачей объединения модулей - групп экспертов с проявленным синергетическим эффектом - в более крупный коллектив, который и будет новой командой. Строительными блоками команд (особенно тех, чья работа зависит от творческого соединения сложных умений и навыков) являются не только индивиды, но и группы. Специалист в области HR или руководитель проекта может значительно упростить задачу объединения большого количества людей с различными компетенциями в эффективно работающую большую команду, просто нанимая группы.

\section{Когнитивное разнообразие}

Если мы обратимся к биологам², математикам ${ }^{3}$, музыкантам [Gould 1994] или экономистам [Schumpeter [1942] 2012; Weitzman 1998], то везде найдём подтверждение тому, что новая, инновационная идея является результатом рекомбинации [Lopes 1992; Hargadon, Bechky 2006; Carnabuci, Bruggeman 2009; Stark 2009]. Чтобы обладать способностью к творчеству, команде нужно определённое разнообразие стилистических элементов, доступных для переработки. В культурных полях, где команды эпизодически собираются, распадаются и собираются вновь в рамках проектов, багаж знаний команды не находится в организационном архиве [Bird 1994; Rowlinson et al. 2010]. Напротив, он является функцией от опыта своих членов, который они накопили в результате взаимодействия с различными стилями в ходе предыдущих проектов. Чем разнообразнее воздействие стилистических практик на членов команды, тем более разностороннее будет команда. Мы называем это когнитивнылм разнообразием.

Там, где когнитивная дистанция между образующими команду группами будет невелика, члены команды находят общий язык. Поскольку практически все члены обладают более-менее схожим стилистическим багажом, им знакомы термины, которые используют их партнёры по команде. Однако малая когнитивная дистанция может означать, что команда обладает скудным репертуаром культурных элементов. Лёгкость коммуникации в знакомой среде означает, что команда, состоящая из гомогенных групп, скорее всего, выберет конформистскую линию поведения.

2 «Новшества происходят из ранее незамеченных взаимосвязей старой материи. Создать значит рекомбинировать», писал великий французский биолог Франсуа Жакоб [Jacob 1977: 1163]. Или, по словам Джона Холланда, исследователя из института Санта-Фе, «рекомбинация играет ключевую роль в процессе открытия, создавая правдоподобные новые правила из частей уже проверенных правил» [Holland 1992: 20].

3 Анри Пуанкаре отмечал: «Творчество как раз и состоит в том, чтобы не делать бесполезные комбинации, а создавать малое число полезных. Изобретение - это умение различать, делать выбор. Среди отобранных комбинаций наиболее плодотворными нередко оказываются те, что были сформированы из частей удалённых друг от друга областей знания» [Poincaré 1985]. 
Напротив, когда составляющие команду группы являются когнитивно (стилистически) различными, её члены могут столкнуться с вавилонским многоголосьем, когда даже один и тот же термин будет использоваться в разных значениях. Когнитивное разнообразие способно встряхнуть существующие коды и категории, что может привести к созданию инновационных продуктов [Brown, Duguid 1991; Stark 2009]. Однако столкновения кодов и категорий недостаточно. Команде нужны структуры, позволяющие выразить их заново с помощью лексикона, сформированного из множества непереводимых языков, но несводимого к их простой сумме. Команды, обладающие этой способностью, с большей вероятностью воспользуются преимуществами такого напряжения. Тогда каким образом можно организовать и мобилизовать когнитивное разнообразие для достижения результатов?

\section{К топологии социокогнитивного пространства}

Ответ на этот вопрос мы ищем, уделяя внимание как социальным, так и когнитивным структурам. Таким образом, наши объяснения одновременно вытекают из недавних исследований, проведённых в рамках социологии культуры и сетевого анализа, и расходятся с ними. Подобно Элиасоф и Лихтерману, мы рассматриваем культуру как стили [Eliasoph, Lichterman 2003]. Вслед за ними, а также другими авторами (см., например: [Becker 1974]) в качестве подходящих единиц анализа мы выделяем не индивидов, а группы, в которых культура являет себя через отношения. И точно также мы рассматриваем «культуру во взаимодействии». Различия состоят в том, что мы (1) принимаем более динамичный подход, поскольку реконструируем, откуда берутся стилистические черты; (2) признаём, что в некоторых ситуациях (возможно, во многих, если не в большинстве) предпочтение отдаётся множественности групп; и (3) уделяем особое внимание этим случаям как пространству, где взаимодействие осуществляется вне групп.

Подобно другим сетевым аналитикам [Ruef, Aldrich, Carter 2003; Uzzi, Spiro 2005; Bellotti 2012; Grund 2012], мы считаем, что при объяснении результативности деятельности (performance) важно учитывать сетевую топологию и формы связи в сплочённых групповых структурах. Однако, в отличие от множества подобных исследований, мы, во-первых, не считаем понятия «посредничество» (brokerage) и «замкнутость» (closure), рассматриваемые по отдельности или в комбинациях удалённых и сплочённых связей в рамках «малого мира», достаточными для представления сетевых свойств. С помощью понятия «структурные складки» мы обозначаем особую позицию в сетевой топологии - позицию, возникающую на пересечении сплочённых сообществ. Как уже отмечалось ранее, со времён Зиммеля в сетевой теории было известно, что кто-либо может одновременно являться членом более чем одной сплочённой группы [Vedres, Stark 2010: 1156]. Но, несмотря на это соображение, методологические ограничения вынудили исследователей распределять членов во взаимоисключающие сплочённые структуры. Концепция структурных складок свободна от такого ограничения и открывает новые возможности для осмысления сетевых структур и сопутствующих процессов.

Наше второе расхождение с предыдущими исследованиями влияния сетей на результативность состоит в том, что мы ставим под сомнение модель сетей как механизмов распространения [Podolny 2001; Owen-Smith, Powell 2004]. Иными словами, мы оспариваем глубоко укоренившееся представление, что сетевой анализ должен моделировать потоки информации. Если сетевая модель распространения рассматривает, как передаются идеи [Coleman 1988; Borgatti, Cross 2003], структурные складки имеют отношение к тому, как эти идеи создаются. В первом случае сети работают как своего рода транспортная система, перемещая информацию от одной точки социального пространства в другую, пересаживая зерно идеи в более питательную организационную среду. Структурные складки, напротив, имеют дело с процессом производства, где по мере нахождения новых ресурсов формулируются новые проблемы. 
Мы ставим перед социологией культуры сетевой вопрос о взаимоотношении между группами в рамках команды и, в частности, спрашиваем: являются эти группы изолированными или образуют структурные складки? Перед сетевым анализом мы ставим с позиции социологии культуры вопрос о том, являются эти группы когнитивно (культурно, стилистически) близкими или удалёнными.

Для разработки данной проблемы мы обратились к работам по семиотике, в частности, к работам Юрия Лотмана, российского семиотика, который утверждал, что «представление о возможности одного идеального языка как оптимального механизма для выражения реальности является иллюзией» [Lotman 2009: 24] ${ }^{4}$. Любая сфера культуры, по мысли Лотмана, предполагает множество кодов. Лотман предлагает мысленный эксперимент: «Если мы представим себе передающего и принимающего с одинаковыми кодами и полностью лишёнными памяти, то понимание между ними будет идеальным, но ценность передаваемой информации минимальной» [Lotman 2009: 4] ${ }^{5}$ Далее Лотман продолжает: «Идеально одинаковые передающий и принимающий хорошо будут понимать друг друга, но им не о чем будет говорить» ${ }^{6}$.

Затем Лотман приводит рисунок из двух пересекающихся окружностей $A$ и $B$ (см. рис. 1), показывающий ситуацию пересечения языкового пространства передающего (говорящего) и принимающего (слушающего) [Lotman 2009: 5]. Эта область пересечения является естественной базой для общения, или коммуникации, в которой непересекающиеся части исключаются из диалога. Но, поразмыслив, можно обнаружить ещё одно противоречие: «Обмен информацией в пределах пересекающейся части смыслового пространства страдает всё тем же пороком тривиальности» ${ }^{7}$

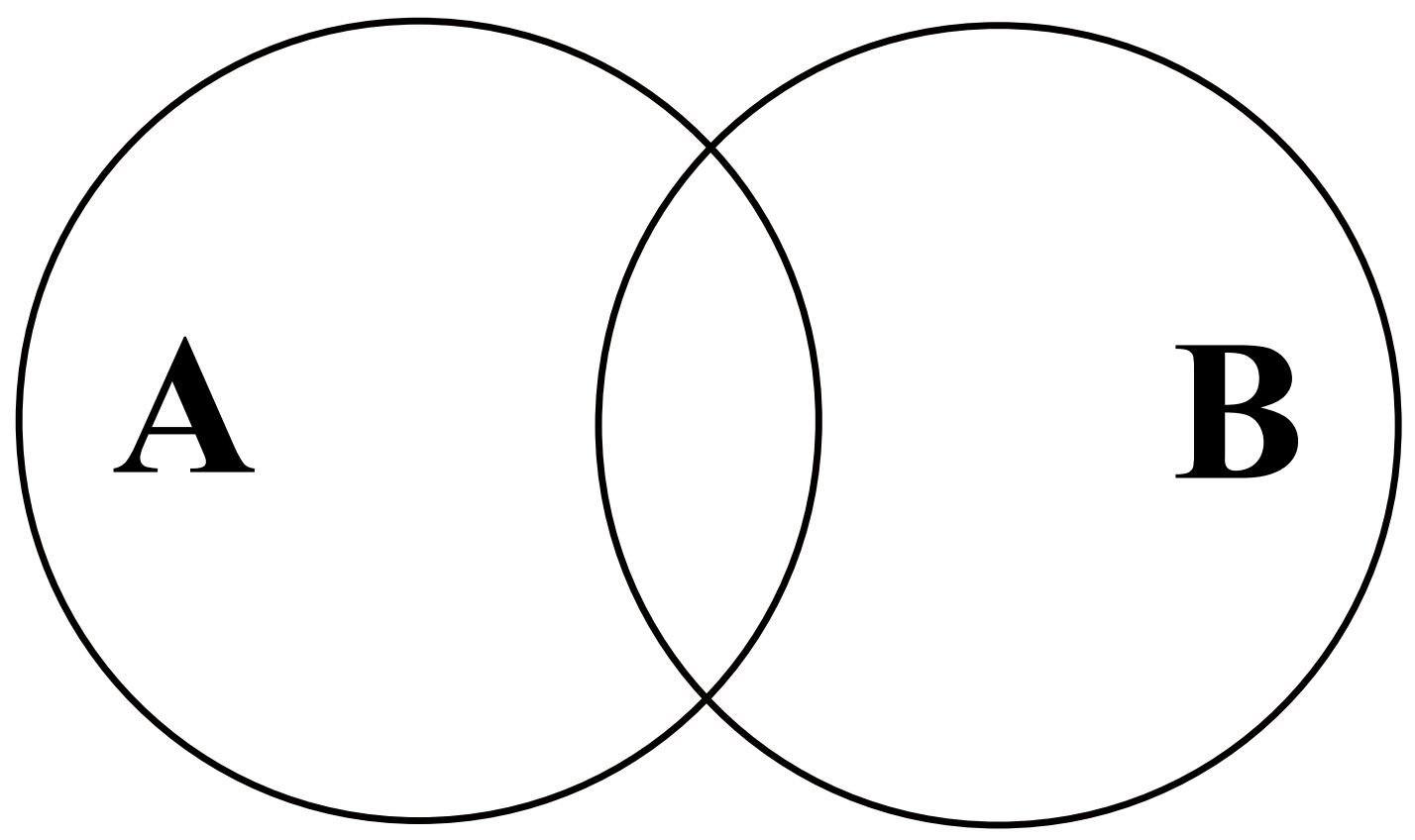

Источник: [Lotman 2009: 5].

Рис. 1. Область пересечения в языковом пространстве

Настоящая ценность диалога состоит во взаимоотношениях между непересекающимися частями: «Чем труднее и неадекватнее перевод одной непересекающейся части пространства на язык другой,

4 Цит. по: Лотман Ю. М. 1992. Культура и взрыв. М.: Гнозис; 9. - Примеч. ред.

5 Цит. по: Там же; 13. - Примеч. ред.

6 Цит. по: Там же; 13. - Примеч. ред.

7 Цит. по: Там же; 14-15. - Примеч. ред. . 
тем более ценным в информационном и социальном отношениях становится факт этого парадоксального общения» [Lotman 2009: 5] . Такая структура порождает напряжение в результате следующего противоречия: с одной стороны, происходит борьба за лёгкость понимания путём расширения пространства пересечения, а с другой - разворачивается борьба за повышение ценности общения при помощи максимального увеличения непересекающихся пространств [Lotman 2009: 5].

В анализе Лотманом «культурных взрывов» как результата «силового сопротивления, или напряжения» между «непереводимыми кодами» [Lotman 2009: 5; Eco 1990: іх] содержится способ объединения структурного подхода сетевого анализа с вниманием к когнитивным и стилистическим характеристикам новой работы в социологии культуры [DiMaggio 1997; 2011]. Для нас ценность пересечения (структурной складки) пропорциональна трудности (дистанции) перевода когнитивно чуждого материала непересекающихся частей групп, образующих структурную складку. Аналогично ключевым действием является не любое действие на пересечении, а лишь взаимодействие между пересекающимися и непересекающимися частями, которое не описывается понятием «свободное течение информации», которому уделяется столько внимания в конвенциональной сетевой литературе.

Акторы в структурной складке являются инсайдерами для более чем одного сообщества. Будучи таковыми, они пользуются доверием. Что более важно, пользуясь доверием множества групп, они могут поручиться членам одной группы за членов другой. Для творческой команды это является активом, особенно в трудные периоды: «Поверь мне, ты можешь рассчитывать на неё». Доверие не является характеристикой посредничества в случае структурных пустот. На самом деле, оппортунизм не связанного ограничениями брокера рассматривался как одна из его ключевых черт [Burt 1995]. Однако доверие является удвоенным ресурсом для групп, образующих структурные складки. И чем более удалены группы внутри команды, тем большее значение принимает доверие в отношении к напряжению - не для его искоренения, а для удержания в узде, пока не возникнут новые стилистические комбинации.

Кроме того, акторы в структурной складке являются инсайдерами в отношении неявного знания и неформальных кодов более чем одного сообщества. Структурные складки важны не просто потому, что они улучшают переход (translation) с одного кода на другой, но потому, что они ускоряют возникновение примитивного лексикона новых языков, то есть структурные складки - это пространство для появления креольского. Действуя внутри сообществ и иногда совместно с теми, кто находится на пересечении, структурная складка позволяет разработать рудиментарный язык. Там, где когнитивная дистанция велика, даже примитивный лексикон может стать благоприятной отправной точкой для по-настоящему творческой инновации. В совокупности с доверием он способен создать среду, в которой акторы могут справляться с неопределённостью и трудностями перевода.

Акторы структурных складок обладают доступом к большему числу решений. Они напоминают исследованных Маршаллом Гэнзом предводителей профсоюза сельскохозяйственных рабочих (United Farm Workers - UFW), «возглавляющей команды “инсайдеров” и “аутсайдеров”» [Ganz 2000: 1015], чьи разнообразные связи и жизненный опыт предоставляли им множество вариантов коллективного действия [Ganz 2000: 1016]. Лидеры профсоюза имели «“пограничный” опыт, охватывающий культурный и институциональный миры» [Ganz 2000: 1015], поэтому UFW смог одержать верх над традиционным объединением, обладавшим намного большими ресурсами.

Команды, состоящие из когнитивно разнородных групп, которые удерживаются в состоянии напряжения структурными складками, обладают не только более обширным репертуаром действий, но и способностью реконтекстуализировать знание, признавая, что набор известных решений не исчерпывает

8 Цит. по: Лотман Ю. М. 1992. Культура и взрыв. М.: Гнозис; 15. - Примеч. ред. 
возможностей для новых решений [Ganz 2000: 1012] и новых проблем [Lester, Piore 2004]. Структурные складки увеличивают вероятность инноваций, усиливая возможности для преодоления само собой разумеющегося и для перехода к целенаправленному [DiMaggio 1997] и рефлексивному [Stark 2009] мышлению. Есть точка зрения, согласно которой смешение когнитивных стилей и лексиконов, неопределённая семантика множества идентичностей и напряжений по поводу пересекающейся прагматики являются рецептом катастрофы [Zuckerman 1999]. Однако мы полагаем, что когнитивно различные, но пересекающиеся сплочённые групповые структуры могут быть успешны не вопреки такому смешению, неопределённости и трениям, а благодаря им [Giuffre 2001].

Структурные складки, особенно в случае когнитивно удалённых групп, отличаются от посредничества ${ }^{9}$. В случае посредничества, согласно, например, Р. Бёрту, «надёжным путём, чтобы почувствовать себя творческим человеком, является нахождение клиентуры, более несведущей, чем вы сами, и готовой получить выгоду от вашей идеи» [Burt 2005: 389]. Наш подход иной: стимулирующий творчество путь состоит в принадлежности к двум кругам клиентуры, столь же сведущим, как и вы, и в усилении ценности не осознаваемых ни одним из этих двух кругов различий.

Поэтому «пересекающееся разнообразие» (folded diversity) как понятие, то есть образующие структурную складку, но когнитивно различные социолингвистические сообщества, отличается от термина «удалённые связи», которое обычно встречается в анализе социальных сетей, где дистанция рассматривается как социальная дистанция. Для нас структурные складки отражают близость множества инсайдеров. А дистанция для нас является когнитивной дистанцией. Таким образом, наше понятие «пересекающееся разнообразие» указывает на противоречивое и творческое напряжение. Образ, который мы хотим донести, представляет собой топологию, в которой структурные складки сближают группы, а когнитивные различия отталкивают их. Чем больше стилистическая дистанция, тем выше ценность коммуникации, что говорит о том, что структурные складки обеспечивают структурную организацию для креолизации.

\section{Данные}

\section{Предыстория: развитие видеоцер}

Для проверки своей гипотезы о структурных складках и когнитивном разнообразии мы исследовали развитие видеоигр. Подобно искусству, кино и танцам, видеоигры являются выражением культуры. Они не только содержат уже существующие культурные образцы, но также переопределяют и заново создают их. В последние годы многие признают важность культуры в видеоиграх. Примерами такого признания являются недавняя выставка «Искусство видеоигр» в Смитсоновском музее американского искусства, где отмечалась успешная ассимиляция видеоигр в господствующий американский образ жизни ${ }^{10}$, а также запуск в 2006 г. академического журнала «Games and Culture» (G \& C) — «Игры и

9 В своей недавней статье Рональд Бёрт предлагает понятие «усиленная структурная пустота» для концептуализации сетевого свойства, близкого к нашему понятию «структурная складка» [Burt 2014]. Мы не согласны с описанием Бёртом структурной складки как усиленной структурной пустоты. Если Бёрт изучает прежде всего трудности индивидуального посредничества сквозь усиленные пустоты, наше внимание направлено на продуктивное напряжение, которое питает творчество в плотных кластерах. Кроме того, термин «усиленная структурная пустота» предполагает, что сначала возникает мост (Слабая связь. - Ред.), который потом усиливается. Но с тем же успехом может случиться и так, что сначала появляется складка, а после разрыва некоторых связей она становится мостом через пустоту. Здесь существуют интересные теоретические вопросы о сетевых свойствах и их влиянии на инновации, а также о сетевой динамике, которые открыты для обсуждения и проверки. Согласно нашему раннему исследованию, посредники и объединяющие связи (bridging ties) между группами не оказывают влияния на конечные результаты, тогда как структурные складки являются предиктором результативности [Vedres, Stark 2010].

10 Cм. URL: http://www.nytimes.com/2012/03/16/arts/video-games/an-exhibition-in-easy-mode.html 
культура», целью которого является продвижение «инновационных теоретических и эмпирических исследований игр и культуры в среде интерактивных медиа» ${ }^{11}$.

Вряд ли какие-то иные культурные формы испытали взрывной рост, подобный тому, который выпал на долю видеоигр. Ещё 40 лет назад их не существовало, а уже к 2007 г. затраты на видеоигры в мире превысили затраты на киноиндустрию. В 2011 г. игры по этим затратам затмили музыкальную продукцию: было подсчитано, что потребители по всему миру потратили примерно 18 млрд дол. на оборудование и 44,7 млрд дол. на программное обеспечение для игр [Gartner 2011].

За три десятилетия наших исследований индустрия эволюционировала от простых двумерных игр в настольный теннис до сайд-скроллеров и, наконец, до полностью оснащённых трёхмерных виртуальных миров. Беспрецедентный рост был вызван практически беспрерывными инновациями в нескольких поколениях игровых консолей, которые и направляли изменения в «игровой механике» и дизайне [Aoyama, Izushi 2003; Tschang 2007; Bissell 2011].

Подобно многим другим сферам культуры, индустрия видеоигр поощряет новое, особенно когда оно упаковано в узнаваемый потребителями и критиками образ [Lampel, Lant, Shamsie 2000; Hutter 2011]. Безусловно, некоторые видеоигры являются не просто имитацией уже существующих игр. Однако на передовой индустрии всё время ставится эксперимент с единственной проблемой видеоигр: как создать убедительную форму повествования, которая была бы анимирована, возможно, исключительно, действиями пользователей [Bissell 2011].

В непрестанном поиске всё более креативного (и всегда непреодолимого) напряжения между оформленным (зафиксированным) нарративом и текучим (fluid) «людонарративом» проект новой видеоигры ищет способы отличия от других, используя радикально новые игровые механики, новые ракурсы и продвинутую графику, а также комбинируя жанры и создавая новые нарративные стратегии развития персонажа, которые для реализации требуют новых технологий (и, в свою очередь, стимулируют их) [Delmestri, Montanari, Usai 2005; Tschang 2007; Bissell 2011; De Vaan 2014]. Производство видеоигр, следовательно, является средой постоянных инноваций, необходимостью для того, чтобы справляться с эпизодическими технологическими сбоями на фоне неутихающего спроса на свежие идеи со стороны потребителей и критиков.

\section{Сбор данных}

Наша цель состояла в сборе подробных данных о каждой выпущенной в продажу видеоигре в этой глобальной индустрии. Для этого мы использовали данные из разнообразных источников. Основным источником была база данных Moby Games: Game Documentation and Review Project ${ }^{12}$. Moby Games является исчерпывающим репозиторием названий программного обеспечения со сведениями о людях, вовлечённых в процесс разработки, о дате выхода каждой игры, о платформах, на которых поддерживаются игры. База содержит и характеристики игр, такие как жанр и ракурс, а также отзывы критиков. Moby Games покрывает период от зарождения индустрии в 1970-х гг. до нынешнего времени. Следующим нашим шагом было сопоставление Moby Games с немецкой Online Games Datenbank (OGDB) ${ }^{13}$.

11 CM. URL: http://gac.sagepub.com/

12 Game Documentation and Review Project Moby Games находится в свободном доступе по адресу http://www.MobyGames. com. База данных Moby Games является каталогом «всей релевантной информации об электронных играх (компьютерных, консольных или аркадных) и классифицирована по играм» (http:/MobyGames.com/info/faq1\#а). Информация, содержащаяся в этой базе данных, предоставляется создателями веб-сайта и добровольцами из числа членов сообщества Moby Games и проверяется создателями веб-сайта; ошибки могут быть исправлены посетителями веб-сайта.

13 Online Games Datenbank находится в свободном доступе по адресу http://www.ogdb.de. 
Эта база данных дополняет Moby Games, предоставляя более подробную информацию о датах выхода видеоигр. Как Moby Games, так и OGDB заполняются пользователями (crowd sourced), и все записи проверяются модераторами и пользователями этих веб-сайтов. В тех редких случаях, когда ни один из этих двух ресурсов не предоставил надёжной информации о видеоигре или информация двух баз оказывалась противоречивой, мы обращались к другим онлайновым или бумажным ресурсам, таким как «Gamasutra», «IGN», «Crash», «PC Gamer», «Game Informer» и «GamePro».

Полученная в результате база данных содержит информацию о 12422 командах разработчиков и выпущенных ими видеоиграх, охватывает 1979-2009 гг. Для каждой видеоигры мы также составили полный список всех членов команды (как в фильмографии, согласно их специализации: программирование, визуализация, написание сценария, дизайн, музыка и т. п.). Приписав уникальный идентификационный номер (ID) каждому из 139727 человек, мы смогли для каждой команды полностью реконструировать карьеры всех их членов в индустрии видеоигр ${ }^{14}$.

В дополнение к данным о членах команды разработчиков видеоигры, для каждой видеоигры в нашем массиве мы записали все её специфические стилистические элементы (включая восемь жанров, то есть экшен, ролевая игра, симулятор и т. п., выделяя подкатегории в каждом из них), а также шесть ракурсов изображения (то есть от первого лица, от третьего лица, сверху вниз, сайд-скролл и т. п.). Всего получилось 105 стилистических элементов, которые составили основу для измерения новизны и когнитивной дистанции ${ }^{15}$. Для каждой игры мы также записали дату выхода, компьютерную платформу, для которой выпущена игра, студию разработчика, издательский дом и уровень признания критиков. Из этой рабочей базы данных мы исключили игры, выпущенные как компиляционные диски, «довесок» (shovelware), то есть большие сборники, призванные впечатлить потребителя количеством игр, но не их качеством, или переиздания. Мы также исключили игры для мобильных телефонов ${ }^{16}$. Итоговая база данных содержит 8987 видеоигр, произведённых для 81 уникальной компьютерной платформы, включая персональные компьютеры, игровые консоли и карманные компьютеры. Несмотря на исключение 3435 наблюдений (12 422 - 8 987), мы использовали информацию о членстве этих команд для построения наших историко-сетевых переменных. В следующем разделе мы объясним, как это делалось.

\section{Стратегия анализа}

\section{Зависимые переменные}

Чтобы определить инновации в контексте развития видеоигр, мы собрали данные о характеристиках продукта (в данном случае - видеоигр) и данные об экспертных оценках этого продукта. Во-первых, поскольку видеоигры построены на основе кода, написанного на языках, неизвестных и невидимых

14 Нужно заметить, что наше теоретическое и эмпирическое определение истории команд относится к командам, созданным для одноразовых проектов. Таким образом, нас не интересует история команды, как и не интересует, например, общее соотношение побед и поражений бейсбольной команды «New York Yankees», прибыльность корпорации IBM за последние пять лет под управлением действующей команды менеджеров или известность факультета социологии Чикагского университета за последние 100 лет [Abbott 1999]. В отличие от этих институционализированных структур, в которых идентичность команды сохраняется даже при замене ее членов, история более важна для команд, которые набирают членов под конкретный проект и распускают их по его окончании (как в кинопроизводстве).

Список авторы готовы предоставить по запросу.

16 Поскольку мобильные телефоны в качестве игровых устройств являются относительно недавним феноменом и поскольку мобильные телефоны открыли новый потребительский рынок - то есть пользователи мобильных игр недостаточно представлены в группе создателей (в основном это заядлые геймеры) краудсорсинговых баз данных по видеоиграм, данные по видеоиграм для мобильных телефонов неполны. Кроме этого недостатка, видеоигры, производимые для мобильных телефонов, настолько сильно отличаются от игр для консолей, ПК и карманных компьютеров, что их тяжело классифицировать согласно структуре, по которой построены используемые нами краудсорсинговые базы данных. 
большинству потребителей видеоигр, частицы этого кода составляют знаки и выражения, которые могут быть интерпретированы и классифицированы практически кем угодно [Bowker, Star 2000]. Мы используем классификацию знаков и выражений - стилистических элементов в случае видеоигр - для определения дистанции между какой-либо определенной видеоигрой и другими видеоиграми. Точнее, мы помещаем видеоигры в стилистическое пространство, где нахождение в центре означает конвенциональность, а периферийное положение ассоциируется с самобытностью ${ }^{17}$.

Во-вторых, мы измеряем признание критиков (отмечая, что само по себе оно не является свидетельством творческого успеха, изменяющего правила игры) с помощью оценок видеоигр экспертами. В нашей базе данных эксперты являются критиками видеоигр, и их мнение выражено с помощью текста и числовой градации. Кроме того, изменения в числовой градации имеют сильную положительную корреляцию с экспертной оценкой уровня инновационности видеоигры ${ }^{18}$. Однако мы признаём, что поле рецензирования видеоигр управляется правилами и нормами, которые направляют используемые рецензентами стратегии оценки. Такие институциональные силы способны помешать рецензентам признавать в видеоиграх то новое, которое отделяет просто хорошую видеоигру от игры-события (game changer). Сходным образом правила и нормы способны подтолкнуть рецензентов положительно оценивать постепенное улучшение, то есть изменение, которое, безусловно, может поднять продажи, но вряд ли изменит когнитивные границы, в рамках которых разработчики создают видеоигры, а пользователи их потребляют.

Наконец, об игре-событии можно говорить только тогда, когда что-то неконвенциональное получает признание и добивается успеха. Следовательно, мы создали три зависимые переменные, с помощью которых измеряем инновационный характер видеоигр.

Самобытность измеряется той степенью, в которой игра стоит особняком по содержащимся в ней стилистическим элементам относительно всех игр, выпущенных в предшествующие пять лет (если $t$ является годом выпуска данной игры, мы сравнивали её со всеми играми, выпущенными с $t-5$ по $t-1)$. Предшествующие пять лет использовались нами как окно для сравнения ${ }^{19}$. Игры того же года выпуска не включались, чтобы избежать обратной временной последовательности (поскольку не для всех игр в нашей выборке была доступна информация о дне выпуска). Для построения переменной мы закодировали наличие стилистических элементов в видеоигре в качестве бинарного вектора из 105 элементов ${ }^{20}$. Затем мы сравнивали вектор нашей выбранной игры с векторами всех игр, выпущенных в предыдущие пять лет, и рассчитывали дистанцию между данной игрой $i$ и каждой отдельной игрой $j$ следующим образом:

17 Предыдущие исследования утверждают, что значение культурного символа является функцией не столько от характеристик этого символа, сколько от отношений с другими культурными символами [Wuthnow 1987; Mohr 1994]. Мы основываемся на этих работах и используем представляющую эти отношения культурную сеть, чтобы измерить самобытность или конвенциональность культурных продуктов.

18 Внимательное чтение большого сборника рецензий показало, что критики по достоинству оценивают инновационные элементы, на которых построены видеоигры.

19 Мы проводили эксперименты, изменяя окно до семи, пяти, трёх лет и одного года. Несмотря на то что точные оценки коэффициентов и их стандартные ошибки различаются в моделях, где использовались разные окна, направление и уровни значимости переменных являются стабильными для всех этих спецификаций.

20

Некоторые из стилистических элементов являются низкоуровневыми элементами высокоуровненых элементов. Например, «баскетбол» - это элемент более низкого уровня для «спорта». Чтобы учесть эту иерархию в наших данных, мы поэкспериментировали с методом корректировки набора стилистических элементов, ассоциируемых с видеоигрой. Этот метод предполагает удаление высокоуровнего стилистического элемента, если присутствуют входящие в него низкоуровневые стилистические элементы. Мы повторили весь анализ, представленный в данной статье, с учётом скорректированных наборов стилистических элементов, ассоциируемых с видеоиграми. Результаты повторных расчетов показали одинаковые знаки и уровни значимости в сравнении с представленными здесь результатами (которые построены на основе нескорректированных наборов стилистических элементов). 


$$
\left.d_{i j}=1-\left[\sum_{k=1}^{K} f_{i k} f_{j k} / \sum_{k=1}^{K} f_{i k}^{2}\right)^{1 / 2}\left(\sum_{k=1}^{K} f_{j k}^{2}\right)^{1 / 2}\right],
$$

где $f_{i k}=1 / K$, если стилистический элемент $k$ содержится в игре $i$ (и $K$ равно общему числу элементов, содержащихся в игре), и 0 в противном случае. Этот индекс $d_{i j}$ известен как косинусная мера сходства, или косинусный коэффициент, и является робастной и широко используемой мерой во множестве дисциплин для оценки сходства между векторами [Jaffe 1986; Sohn 2001; Evans 2010]. С помощью нормирования числа стилистических элементов в играх $i$ и $j$ косинусный коэффициент измеряет сходство без чрезмерного эффекта от разницы в количестве использованных в игре стилистических элементов [Evans 2010].

Для каждой видеоигры мы получили вектор расстояний между отдельной игрой $i$ и всеми другими играми $\{1,2, \ldots, j\}$, которые были разработаны в предшествующие пять лет. Для построения переменной самобытности этого вектора мы усредняем расстояния:

$$
\text { самобытность }=\sum_{j=1, j \neq i}^{N} d_{i j} / N \text {. }
$$

Признание критиков измеряется средним баллом, присвоенным видеоигре профессиональными критиками в индустрии. Мы используем индикатор из базы данных Moby Games, который представляет собой взвешенное среднее нормированных рейтингов и отзывов профессиональных критиков в известных онлайновых, телевизионных и печатных СМИ (нормирование нужно, потому что различаются рейтинговые системы: некоторые колеблются от одной до пяти звёзд, другие - от 1 до 10 баллов и т. п.). Полученные баллы варьируют от 0 до 100. Чем выше балл, тем выше коллективное мнение критиков об игре ${ }^{21}$. Типичным источником отзыва является журнал или веб-сайт о видеоиграх. В качестве примеров таких источников можно привести «Game Informer» (США), «РC Power Play» (Австралия), Jeuxvideo.com (Франция), а также немецкий веб-сайт eurogamer.de. Moby Games ревностно следит за стандартами качества источников рецензий, индексируемых при подсчёте баллов ${ }^{22}$. Чтобы быть включённым в индекс, источник рецензий должен, например, опубликовать минимум 100 рецензий, соответствовать профессиональным стандартам и сделать публикацию не позднее чем через месяц после выхода игры. Баллы отражают суждения о качестве игры после её выхода, а не рефлексию ex post c оттенками ностальгии. Из анализа исключались блоги и медиаресурсы, которые агрегируют оценки индивидуальных пользователей или критиков ${ }^{23}$.

Мы считаем продукт игрой-событием, если он стилистически самобытен и высоко оценен критиками. Для поиска таких игр мы разделили базу данных на две взаимоисключающие части - игры-события и рядовые игры - на основании пороговых значений, установленных для распределений самобытности и признания критиков. Эти разделения образуют базис для фиктивной переменной, равной 1 для всех игр-событий и 0 для остальных. Мы начинаем с того, что кодируем продукт как игру-событие, если значения самобытности и признания критиков превышают значения 60-го процентиля для обеих переменных. Игры с меньшими значениями по одной или обеим переменным кодировались как рядовые. В результате мы получили 929 игр-событий и 4579 рядовых игр. Следующим шагом мы снизили количество игр, классифицированных как игры-события. Для этого было поднято пороговое значение до 70-го и 80-го процентилей. При использовании 70-го процентиля как минимального порогового значения мы получили 502 игры, представляющие 10\% от всех игр в выборке. Восьмидесятый процентиль в распределениях даёт нам 212 игр-событий, что равно 4\% выборки. Поскольку эти пороговые

21 Веб-сайт Moby Games (обращение: 22 октября 2013 г.).

22 Подробнее см.: http://www.mobygames.com/info/mobyrank (обращение: 22 октября 2013 г.).

23 Такие веб-сайты, как Metacritic, GameRankings, Rotten Tomatos и GameStats, считаются агрегатными источниками, поэтому мы их не учитывали при расчёте баллов. 
значения несколько произвольны, мы протестировали робастность наших результатов, изменяя пороговое значение. Таблицы в данной статье представляют оценки коэффициентов для порогового значения 60-го процентиля, но при представлении результатов мы также показываем оценки коэффициентов для моделей, основанных на 70-м и 80-м процентилях.

На рисунке 2 графически представлен процесс разделения базы данных на игры-события и рядовые игры. В левой части рисунка - диаграмма рассеяния всех наблюдений, а в правой части отображены только наблюдения, закодированные как игры-события.

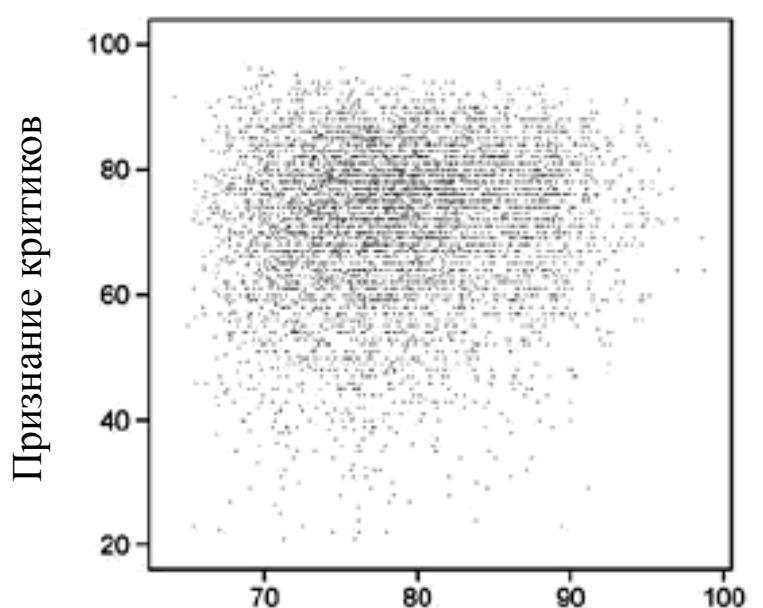

Самобытность

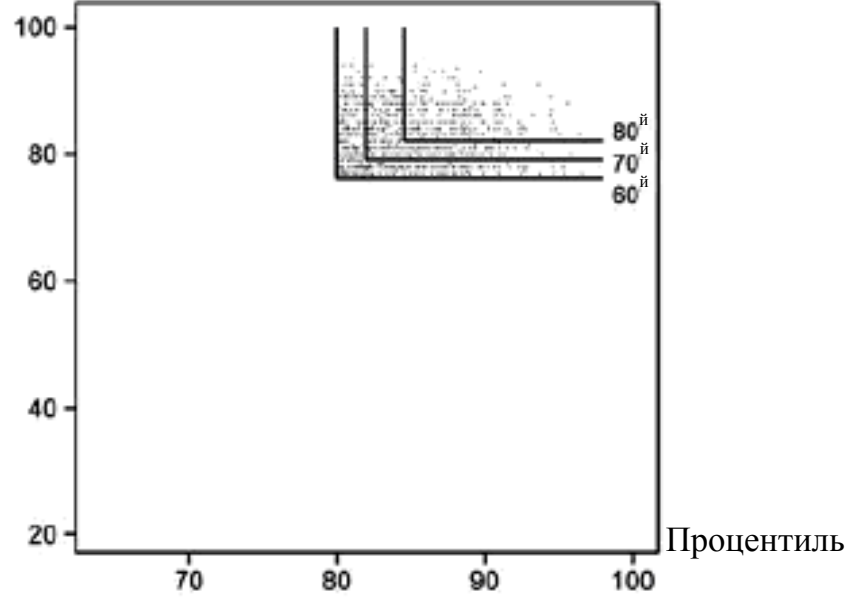

(100

Рис. 2. Графическое изображение определения игры-события

\section{Независимые переменные}

Для начала мы определим два операциональных понятия, которые формируют базис для измерения множества независимых переменных: (1) группы и (2) когнитивная дистанция. Во-первых, мы используем понятие «группа» во всех случаях, когда по меньшей мере три члена команды ранее сотрудничали друг с другом в предыдущих проектах по разработке видеоигр. Конечно, в некоторых случаях будут обнаружены абсолютно одинаковые группы (в терминах её состава) или частично одинаковые. Например, если индивиды $A, B$ и $C$ сотрудничали в производственных проектах в 1999, 2001 гг. и снова - в 2003 г., то для команды 2003 г. эта социальная структура из трёх человек фиксируется как одна группа. Аналогично, если индивиды $A, B$ и $C$ сотрудничали в производственном проекте в 1999 г., а индивиды $A, B, C$ и $D-$ в 2001 г. и снова — в 2003 г., тогда для видеоигры 2003 г. совокупности из трёх человек и четырёх человек объединяются и будут записаны как одна группа, потому что первая группа является собственным подмножеством второй и третьей, $\{A, B, C\} \subseteq\{A, B, C, D\}^{24}$. Таким образом, данная группа содержит подмножество всех членов команды, которые хотя бы однажды сотрудничали друг с другом в одном проекте или более ${ }^{25}$.

24 Мы экспериментировали с несколькими альтернативными определениями групп. Сначала переопределили группы как социальные структуры, которые имели опыт сотрудничества до разработки определённой видеоигры как минимум 8 двух случаях. Данное пороговое значение привело к схожим результатам, которые представлены здесь. Однако использование более высоких пороговых значений (более двух) уменьшило количество команд со множественными группами до менее 5\% от выборки, что сделало невозможными оценки коэффициентов.

25 Примером сходной организации людей являются советы директоров [Mizruchi 1996]. В значительной части литературы о переплетённых директоратах двумерные сети сводятся к одномерным для изучения того, как фирмы связаны друг с другом директорами. Однако любопытно, что аналогом наших команд являются настоящие coветы, где совместно заседают директоры. Эти директоры зачастую имеют (имели) множественные должности, и если множество директоров данного совета также совместно присутствуют в совете другой компании, они могут действовать как группа и вырабатывать групповой стиль. 
Во-вторых, мы определяем когнитивную дистанцию между двумя индивидами или группами как несходство векторов, содержащих значения стилистических элементов, влиянию которых данные индивиды или группы были подвержены. Воздействие мы фиксируем не в бинарных значениях, а в частотных. Стилистический портфель члена команды или группы описывает распределение степени воздействия со стороны возможного набора из 105 уникальных элементов, описанных выше — в разделе о данных. Затем на основании их стилистических портфелей рассчитываем расстояние попарно между членами команды или парами групп, вычисляя косинусную меру сходства (уравнение (1)).

Мы исследуем, как группы связаны между собой и, особенно, образуют ли они структурные складки, где пересекаются сплочённые группы. Поскольку у нас есть особые индикаторы для когнитивных структур и социальных структур, можно проверить, объясняется ли дисперсия наших зависимых переменных с помощью когнитивно удалённых групп, образующих структурные складки.

Образование структурных складок измеряется степенью взаимного проникновения групп при возникновении структурной складки. Различные группы могут иметь одного общего члена или более. Для каждой пары групп фиксируем долю общих членов, затем суммируем эти доли и полученное значение делим на максимально возможное число складок, которое равно $[N *(N-1)] / 2$ для множества из $N$ групп. Другими словами, эта переменная отражает усреднённое пересечение между группами в команде.

Пересекающееся разнообразие (folded diversity) является наиболее интересной для нас переменной, поскольку она отражает степень взаимопроникновения когнитивно удалённых групп, представленную количеством индивидов, которые выступают членами обеих групп. Сначала была создана матрица, описывающая когнитивную дистанцию между парами групп в рамках команды разработчиков видеоигры. Эта дистанция основана на влиянии различных стилистических элементов на членов группы и описывается уравнением (1). Затем перемножаем элементы этой матрицы расстояний и элементы матрицы структурных складок. Наконец, делим сумму этих поэлементных умножений на $[N *(N-1)] / 2$ возможных границ между группами. Другими словами, каждая пара групп, образующих структурную складку, взвешивается на когнитивную дистанцию между ними.

Когнитивное разнообразие отражает степень неоднородности между стилистическими портфелями членов команды. Рассчитываем дистанцию между стилистическим портфелем каждого члена команды и портфелями всех остальных членов с помощью косинусной меры сходства, где $f_{i k}$ - подмножество стилистического элемента $k$ в множестве всех стилистических элементов $K$ для $i$-го члена команды. Затем каждое значение $d_{i j}$ использовали для построения матрицы $D_{g}$ для каждой игры $g$, что позволяет рассчитать переменную когнитивного разнообразия для игры $g$ :

$$
\text { когнитивное разнообразие }=\sum_{i=1}^{N} d_{i j} * \frac{1}{N},
$$

где $d_{i j}$ отражает неоднородность $(1-$ абсолютно различен; $0-$ идентичен) между $i$-м и $j$-м членами команды, а $1 / N$ просто трансформирует сумму всех пар в среднее значение.

Чтобы проиллюстрировать вычисление этой переменной, возьмём две команды, состоящие из трёх членов. В первой команде прошлое стилистическое влияние на членов представлено как $A B C, A B C$, $A B C$. Во второй команде прошлое влияние на членов оказалось $A A A, B B B$ и $C C C$. В каждой команде диапазон элементов одинаков. Тем не менее у первой команды более короткая когнитивная дистанция. Все её члены обладают одним и тем же репертуаром, и каждый из них может с лёгкостью коммуницировать с любым другим по поводу любого стилистического элемента. У второй команды когнитивная дистанция больше. 


\section{Контрольные переменные}

Чтобы учесть возможности посредничества в команде, мы включили индикатор ограничений, используемый Бёртом [Burt 2005]. Ограничения могут влиять как на зависимые переменные, так и на пересекающееся разнообразие, тем самым действуя как возмущающий фактор ${ }^{26}$.

Средний размер группы мы операционализировали, подсчитав среднее количество людей в группах какой-либо команды. Также в модель включён квадрат этой переменной для оценки того, изменяется ли влияние среднего размера группы на наши зависимые переменные по мере роста групп. Число групn отражает количество групп в команде.

Количество членов команды является числом индивидов, вовлечённых в производство видеоигры. Эта переменная включена в регрессионную модель, чтобы учесть вариацию зависимой переменной, связанной с простым увеличением количества человеческих ресурсов. Можно возразить, например, что большее число членов приводит к созданию более качественных игр независимо от того, разнороднее они или сплочённее. Переменная новички отражает число членов команды, у которых не было предыдущего опыта производства видеоигр. В отличие от своих опытных коллег, у которых есть солидный послужной список и узнаваемые таланты, новички, скорее всего, будут иметь мало опыта и неподтверждённые умения [Guimera et al. 2005]. Onыл создания игр измеряет среднее количество игр, которые члены команды создали в прошлом, до производства данной игры. В частности, эта переменная измеряет влияние со стороны опытных профессионалов производства видеоигр. Данная переменная, видимо, является прокси к среднему показателю опыта и навыков, находящихся в распоряжении членов команды.

Прошльй балл в отзывах измеряет для каждой команды средний балл в рецензиях на те игры, в создании которых члены команды принимали участие в предыдущие пять лет. Переменная отражает среднее качество членов команды, участвующих в производстве видеоигры. Хотя квалификация каждого члена команды напрямую не измеряется, а определяется успех созданных игр в среде критиков, мы считаем, что данная переменная является хорошим индикатором качества члена команды. Эта переменная включена в модель, так как может оказаться, что качество членов команды влияет на процесс формирования команды.

Bысокопроизводительные члены команды отражают исключительно высокую производительность членов команды, а не среднюю. В частности, было подсчитано число членов команды, которое за прошлые пять лет участвовало в производстве игры, попавшей по рейтингу в 95-й процентиль из всех игр, выпущенных в том году. Участие в производстве таких высокорейтинговых игр является как признаком индивидуальных способностей, так и фактором, влияющим на индивидуальный статус в отрасли.

Заслуженный член команды - фиктивная переменная, показывающая, есть ли в команде участник или участники, награжденные Game Developers Choice Award ${ }^{27}$. Переменная контролирует вариации в процессах отбора в команде, на которые могут влиять изменения в статусе и распределении ресурсов.

26 Возможности посредничества (низкий уровень ограничений) могут служить альтернативным причинным механизмом, с помощью которого связанные групповые структуры способны влиять на работу команды. То, что допустимо интерпретировать как действие рекомбинации поверх пересекающихся групп, предположительно вызвано ростом производительности разработчиков на пересечении групп, так как им доступны возможности посредничества.

27 Game Developers Choice Awards ежегодно вручаются на конференции разработчиков игр наиболее инновационным и креативным дизайнерам игр. Премия была основана в 2001 г.; предшествовала премия Spotlight Awards (1997-1999 гг.). Мы использовали информацию об обеих премиях. 
Интегрированное производство - фиктивная переменная, равная 1, если издатель и разработчик видеоигры являются различными юридическими лицами, и равная 0 , если разработка и издательская деятельность объединены в руках одной фирмы или разных подразделений одного и того же юридического лица ${ }^{28}$.

Возраст фирмы отражает среднее число лет работы издателя и разработчика в отрасли производства видеоигр. Переменная была использована в модели, чтобы учесть рутинные практики и уровень опыта, накопленные фирмой и являющиеся ресурсом команды. В случае, когда видеоигра производится одной фирмой, значение переменной равно числу лет, которые фирма проработала в отрасли.

Количество элементов - числовая переменная, которая равна количеству элементов в видеоигре. Мы включили эту переменную, чтобы учесть уровень сложности композиции игры.

В модели включены также фиктивные переменные жанра для учёта вариации зависимых переменных, связанной с усреднённой популярностью отдельных жанров. Видеоигры в высококонкурентных жанрах были представлены в качестве ориентиров для других - возможно, более высококачественныхигр, что, вероятно, влияет на балл, присваиваемый игре экспертом. Фиктивные переменные жанра не являются взаимоисключающими. Игры могут содержать в своём геймплее элементы множества жанров, следовательно, мы включили в анализ все восемь жанров в качестве фиктивных переменных.

Фиктивные переменные года учитывают временные тренды в критических отзывах на игры. По мере развития индустрии видеоигр менялись и стандарты критики, а сами критики устанавливали социальные связи друг с другом. Ещё один связанный со временем вопрос, который отражается в переменных года, состоит в том, что по мере развития отрасли команды по своей природе становились более разнородными. Фиктивные переменные страны отражают тот факт, что игры, выпущенные во множестве стран, будут, скорее всего, отрецензированы большим количеством критиков, выросших в разной культурной среде. Наконец, мы включили в свои модели фиктивные переменные платформы для учёта вариации зависимых переменных, связанной с характеристиками платформы, для которой выпускалась видеоигра. Игровые платформы имеют собственные ниши, что очерчивает границы, в рамках которых производители видеоигр могут позиционировать свой продукт. Более того, рецензенты видеоигр могут использовать структурно различающиеся критерии для оценки видеоигр, произведённых для разных платформ.

\section{Memodы}

Для проверки своих гипотез о роли групп в рамках команд и их влиянии на инновационную деятельность мы провели симуляцию и регрессионный анализ. Во-первых, чтобы показать, что команды составлены из групп, а не из индивидов, мы разработали симуляционную модель, которая сравнивает плотность сети внутри наблюдаемых команд с плотностью сети внутри команд, созданных с помощью последовательности альтернативных процессов сборки команды. Во-вторых, чтобы показать, что пересекающееся разнообразие вносит свой вклад в инновационную деятельность команд, мы использовали методы множественной регрессии. Ниже эти методы будут описаны подробнее.

Симулящии. Мы смоделировали процессы, с помощью которых команды могут собираться воедино. Суть этих моделей в том, что если группы действительно можно обнаружить и идентифицировать,

28 Для построения этой переменной мы проследили историю основания, слияний и поглощений для всех фирм в нашей базе данных. Фирмы, учреждённые в качестве подразделений, филиалов или торговых марок других фирм, были закодированы как зависимые от материнской компании. В случае если фирма была приобретена другой фирмой, мы также кодировали зависимость от материнской компании начиная с даты приобретения. 
а индивиды отбираются в команду в качестве членов групn, то плотность сети в такой команде будет выше, чем плотность сети команд, которые сформированы с помощью процесса отбора, не учитывающего групповые структуры.

Исходя из работы М. Руефа и его соавторов выделяем три основных альтернативных принципа, на базе которых может осуществляться формирование профессиональных команд: (1) отбор на основе социальных сетей; (2) отбор на основе сходных навыков; (3) отбор на основе организационных границ [Ruef, Aldrich, Carter 2003]. Применяем все эти три принципа отбора и операционализируем их, проводя симуляционное моделирование формирования команды на основе каждого из них. В качестве точки отсчёта для каждой симуляции фиксируем характеристики (социальная сеть, навыки, принадлежность к фирме) разработчиков в наблюдаемой команде и задаём следующий вопрос: какой была бы плотность сети, если бы процесс набора в команду проводился согласно этим принципам без учёта групповой структуры? Теперь опишем, в чём состоят выбранные нами стратегии операционализации данных процессов.

В качестве исходной модели мы симулируем «наивно» сконструированную команду, делая это путём выборки потенциальных членов из всех доступных людей в отрасли в определённый год. Безусловно, такая модель вряд ли используется при формировании команд разработчиков видеоигр, однако сравнение её результатов с результатами других стратегий симуляции может дать нам важный ориентир.

Для сценария на основе сходных навыков каждому члену исходной команды ставится в соответствие выборка из $N$ его ближайших соседей. Ближайшие соседи определяются как индивиды, имеющие наиболее похожий портфель навыков с данным членом команды за предыдущий год. Значение $N$ меняется от года к году и определяется как число разработчиков в первом процентиле распределения дистанции разработчика видеоигр ${ }^{29}$. Это означает, что после расчёта близости навыков между разработчиком $i$ и всеми остальными разработчиками $1, \ldots, j$, в выборку отбирается $1 \%$ наиболее близких разработчиков. Затем для каждого члена команды случайно выбираем одного человека из объединения определённого члена команды $i$ и его выборки из $N$ ближайших соседей. Проделываем это для каждого члена команды и повторяем процедуру 100 раз.

Для симуляции формирования команды также использовалась информация об организационных структурах в наших данных. Мы не ограничиваемся лишь отбором наёмных работников, принятых на работу фирмами, производившими наблюдаемую игру. Это привело бы к исключению всех наблюдений, связанных с новой фирмой, то есть не имеющей истории в отрасли. Кроме того, даже для фирм, которые уже производили игры до наблюдаемого случая, но использовали для этого меньшую команду, чем в наблюдаемый период, мы не сможем симулировать команду, просто потому, что массив, который мы можем оперировать, слишком мал. Мы производим выборку из индивидов, нанятых фирмами, на которые работали члены наблюдаемой команды в течение последних пяти лет ${ }^{30}$. Это означает, что отбор в команду производится из ограниченного числа фирм, в которых ранее работали действительные члены команды. Из полученного множества индивидов, которое опять включает наблюдаемых членов команд, отбираем $N$ человек, где $N$ равно числу членов изучаемой команды. Повторяем процедуру 100 раз и подсчитываем среднюю плотность сети на основе результатов этих 100 симуляций.

29 Доля, для которой число альтернативных разработчиков для разработчика і больше или равно единице за любой год, это $1 \%$.

30 Мы экспериментировали с другими пороговыми значениями, но результаты были качественно схожими. Кроме того, мы скорректировали чрезмерное представительство людей, нанятых организующей фирмой, в наблюдаемой команде, введя веса при отборе из множества потенциальных членов. Иными словами, если есть две фирмы, которые нанимали членов наблюдаемой команды, и на одну из этих фирм приходится большинство нанятых, мы корректируем это чрезмерное представительство с помощью стратифицированной случайной выборки из массива потенциальных членов. 
Наконец, для отбора при помощи социальных связей мы зафиксировали все контакты в эгоцентричных сетях членов команды. Эти эгоцентричные сети представляют собой отношения, сформированные сотрудничеством в проектах за предыдущие пять лет. Совокупность членов команды и их контактов представляет собой множество всех потенциальных членов симулируемой команды. Фактически такой метод сборки команды предполагает объединение членов из локальных социальных сетей, в которых укоренены члены реальной команды. Затем мы случайно отбираем $N$ индивидов из этого множества, где $N$ равно числу членов наблюдаемой команды. Мы повторяем эту процедуру 100 раз для каждой наблюдаемой команды и подсчитываем среднюю плотность сети в симулируемых командах.

Регрессии. Второй стратегией, с помощью которой мы исследуем наши гипотезы, является построение множества регрессионных уравнений. Первый пакет моделей показывает, как социальная и когнитивная композиции производственных команд в индустрии видеоигр взаимосвязаны с уровнем caмoбыmности видеоигры. Эта зависимая переменная зафиксирована для всех 8987 видеоигр в нашей базе данных, и поскольку это нормально распределённая числовая переменная, мы проверяем свои гипотезы с помощью простой линейной регрессии по методу наименьших квадратов (МНК).

Во втором пакете регрессионных моделей мы оцениваем коэффициенты для независимых переменных, когда зависимой переменной является признание критиков. Как и самобытность, переменная признание критиков является числовой и распределена нормально. Следовательно, мы рассчитываем коэффициенты для независимых переменных с использованием МНК-регрессий. Переменная признание критиков наблюдаема только для подвыборки (5 508 ед.) из совокупности всех видеоигр, то есть отзывы в отобранных источниках рецензий получили $61 \%$ игр. Смещение выборки может исказить наши результаты. Часто используемый подход для решения подобных проблем выборки состоит в расчёте двухэтапной модели отбора Дж. Хекмана [Heckman 1979]. В приложение А включено обсуждение этой техники моделирования, и мы рассчитали наши регрессионные модели с переменной признание критиков в качестве зависимой переменной, используя двухэтапную модель Хекмана для обеспечения проверки надежности используемых в статье моделей.

Игра-событие является бинарной переменной, поэтому используется логистическая регрессия. Играсобытие равна 1, если переменные самобытность игры и признание критиков игры превышают 60-й процентиль. Поскольку игра-событие построена на основе признания критиков, её значения также ненаблюдаемы для 39\% выборки. Чтобы проверить, что наши расчёты не страдают от смещения выборки, в приложении А представлены результаты двумерной пробит-регрессии, которая корректирует смещение выборки.

В заключение рассмотрены возможные вопросы, возникающие из ненаблюдаемых факторов, которые стабильны на уровне организации, но варьируют между организациями и коррелируют как с нашими зависимыми, так и с независимыми переменными. Можно полагать, что многие команды вложены в организацию и эти организации могут обладать ненаблюдаемыми компетенциями, что способно привести к нахождению ложных связей между независимыми и зависимыми переменными в наших моделях. Поэтому мы заново рассчитали модели, зафиксировав эффект фирмы. Результаты и их обсуждение можно найти в приложении Б.

В таблице 1 представлена описательная статистика, а в таблицах 2 и 3 - корреляционные матрицы для всей выборки и для усечённой выборки соответственно. Эти таблицы показывают, что корреляции некоторых пар переменных превышают 0,70. В эти пары входят, но ими не ограничиваются, nересекающееся разнообразие и структурные складки, число членов команды и число групп, новички и число членов командbl. Чтобы оценить, завышают ли большие коэффициенты корреляции дисперсии этих переменных, мы рассчитали коэффициент VIF и пришли к выводу, что можем интерпретировать оценки в наших моделях ( $V I F$ не превысил 3 для каждой переменной). 
Таблица 1

Описательная статистика

\begin{tabular}{|c|c|c|c|c|c|}
\hline Переменные & $\begin{array}{l}\text { Количество } \\
\text { наблюдений }\end{array}$ & Минимум & Максимум & Среднее & $\begin{array}{c}\text { Стандартное } \\
\text { отклонение }\end{array}$ \\
\hline Самобытность & 8987 & 60,88 & 98,94 & 79,33 & 6,78 \\
\hline Признание критиков & 5508 & 21,00 & 96,00 & 71,44 & 12,33 \\
\hline Игра-событие & 5508 & 0,00 & 1,00 & 0,17 & 0,37 \\
\hline Пересекающееся разнообразие & 8987 & 0,00 & 1,00 & 0,30 & 0,27 \\
\hline Когнитивное разнообразие & 8987 & 0,00 & 1,00 & 0,42 & 0,16 \\
\hline Структурные складки & 8987 & 0,00 & 0,94 & 0,24 & 0,22 \\
\hline Ограничение & 8987 & 0,00 & 77,48 & 7,22 & 5,67 \\
\hline Средний размер группы & 8987 & 0,00 & 211,00 & 6,66 & 5,76 \\
\hline Число групп & 8987 & 0,00 & 186,00 & 7,85 & 12,34 \\
\hline Число членов & 8987 & 6,00 & 459,00 & 40,55 & 46,63 \\
\hline Число новичков & 8987 & 0,00 & 247,00 & 10,34 & 12,95 \\
\hline Опыт создания игр & 8987 & 0,00 & 9,17 & 2,07 & 1,08 \\
\hline Прошлый балл в отзывах & 8987 & 0,00 & 95,00 & 69,03 & 17,49 \\
\hline Высокопроизводительные члены команды & 8987 & 0,00 & 355,00 & 14,49 & 26,60 \\
\hline Разработчик-звезда & 8987 & 0,00 & 1,00 & 0,01 & 0,09 \\
\hline Интегрированное производство & 8987 & 0,00 & 1,00 & 0,32 & 0,47 \\
\hline Средний возраст фирмы & 8987 & 1,00 & 31,00 & 13,72 & 6,75 \\
\hline Количество элементов & 8987 & 1,00 & 21,00 & 4,66 & 1,60 \\
\hline
\end{tabular}

Матрица корреляций для полной выборки

Таблица 2

\begin{tabular}{|c|c|c|c|c|c|c|c|c|c|c|c|c|c|c|c|}
\hline & 1 & 2 & 3 & 4 & 5 & 6 & 7 & 8 & 9 & 10 & 11 & 12 & 13 & 14 & 15 \\
\hline \multicolumn{16}{|l|}{ 1. Самобытность } \\
\hline $\begin{array}{l}\text { 2. Пересекающееся } \\
\text { разнообразие }\end{array}$ & 0,01 & & & & & & & & & & & & & & \\
\hline $\begin{array}{l}\text { 3. Когнитивное } \\
\text { разнообразие }\end{array}$ & 0,02 & $-0,01$ & & & & & & & & & & & & & \\
\hline $\begin{array}{l}\text { 4. Структурные } \\
\text { складки }\end{array}$ & 0,02 & 0,78 & $-0,16$ & & & & & & & & & & & & \\
\hline 5. Ограничение & $-0,24$ & 0,18 & 0,07 & 0,07 & & & & & & & & & & & \\
\hline $\begin{array}{l}\text { 6. Средний размер } \\
\text { группы }\end{array}$ & $-0,07$ & 0,19 & $-0,31$ & 0,25 & 0,26 & & & & & & & & & & \\
\hline 7. Число групп & $-0,22$ & 0,20 & $-0,03$ & 0,06 & 0,75 & 0,29 & & & & & & & & & \\
\hline 8. Число членов & $-0,23$ & 0,13 & 0,02 & 0,01 & 0,74 & 0,45 & 0,85 & & & & & & & & \\
\hline 9. Число новичков & $-0,13$ & 0,02 & 0,14 & $-0,07$ & 0,45 & 0,15 & 0,44 & 0,71 & & & & & & & \\
\hline $\begin{array}{l}\text { 10. Опыт создания } \\
\text { игр }\end{array}$ & $-0,11$ & 0,30 & $-0,13$ & 0,30 & 0,34 & 0,29 & 0,36 & 0,19 & $-0,21$ & & & & & & \\
\hline $\begin{array}{l}\text { 11. Прошлый балл } \\
\text { в отзывах }\end{array}$ & $-0,09$ & 0,19 & 0,22 & 0,16 & 0,20 & 0,19 & 0,14 & 0,18 & 0,12 & 0,26 & & & & & \\
\hline $\begin{array}{l}\text { 12. Высокопроиз- } \\
\text { водительные члены } \\
\text { команды }\end{array}$ & $-0,19$ & 0,12 & $-0,06$ & 0,03 & 0,59 & 0,48 & 0,79 & 0,89 & 0,48 & 0,28 & 0,21 & & & & \\
\hline $\begin{array}{l}\text { 13. Разработчик- } \\
\text { звезда }\end{array}$ & $-0,02$ & 0,02 & 0,01 & 0,00 & 0,12 & 0,07 & 0,18 & 0,17 & 0,06 & 0,09 & 0,03 & 0,19 & & & \\
\hline $\begin{array}{l}\text { 14. Интегрирован- } \\
\text { ное производство }\end{array}$ & 0,04 & 0,09 & $-0,06$ & 0,07 & $-0,04$ & 0,05 & 0,05 & 0,05 & 0,05 & $-0,02$ & 0,06 & 0,08 & 0,03 & & \\
\hline $\begin{array}{l}\text { 15. Средний воз- } \\
\text { раст фирмы }\end{array}$ & $-0,18$ & 0,19 & 0,03 & 0,12 & 0,48 & 0,26 & 0,48 & 0,47 & 0,24 & 0,36 & 0,24 & 0,45 & 0,12 & $-0,06$ & \\
\hline $\begin{array}{l}\text { 16. Количество } \\
\text { элементов }\end{array}$ & $-0,29$ & 0,00 & $-0,01$ & $-0,01$ & 0,06 & 0,06 & 0,06 & 0,08 & 0,06 & 0,01 & 0,04 & 0,07 & 0,01 & $-0,01$ & 0,07 \\
\hline
\end{tabular}


Матрица корреляций для усечённой выборки

Таблища 3

\begin{tabular}{|c|c|c|c|c|c|c|c|c|c|c|c|c|c|c|c|c|c|}
\hline & 1 & 2 & 3 & 4 & 5 & 6 & 7 & 8 & 9 & 10 & 11 & 12 & 13 & 14 & 15 & 16 & 17 \\
\hline \multicolumn{18}{|l|}{ 1. Самобытность } \\
\hline 2. Признание критиков & 0,09 & & & & & & & & & & & & & & & & \\
\hline 3. Игра-событие & 0,44 & 0,41 & & & & & & & & & & & & & & & \\
\hline 4. Пересекающееся разнообразие & 0,01 & 0,08 & 0,07 & & & & & & & & & & & & & & \\
\hline 5. Когнитивное разнообразие & 0,04 & $-0,05$ & $-0,01$ & $-0,06$ & & & & & & & & & & & & & \\
\hline 6. Структурные складки & 0,05 & 0,06 & 0,07 & 0,76 & $-0,22$ & & & & & & & & & & & & \\
\hline 7. Ограничение & $-0,26$ & 0,06 & $-0,06$ & 0,06 & 0,08 & $-0,07$ & & & & & & & & & & & \\
\hline 8. Средний размер группы & $-0,08$ & 0,16 & 0,06 & 0,17 & $-0,41$ & 0,25 & 0,19 & & & & & & & & & & \\
\hline 9. Число групп & $-0,24$ & 0,09 & $-0,06$ & 0,14 & $-0,07$ & $-0,01$ & 0,73 & 0,29 & & & & & & & & & \\
\hline 10. Число членов & $-0,24$ & 0,16 & $-0,02$ & 0,06 & $-0,02$ & $-0,07$ & 0,72 & 0,45 & 0,84 & & & & & & & & \\
\hline 11. Число новичков & $-0,11$ & 0,16 & 0,05 & $-0,02$ & 0,14 & $-0,11$ & 0,43 & 0,15 & 0,42 & 0,70 & & & & & & & \\
\hline 12. Опыт создания игр & $-0,14$ & 0,02 & $-0,03$ & 0,27 & $-0,23$ & 0,27 & 0,32 & 0,30 & 0,38 & 0,19 & $-0,24$ & & & & & & \\
\hline 13. Прошлый балл в отзывах & $-0,01$ & 0,30 & 0,13 & 0,13 & 0,12 & 0,11 & 0,12 & 0,19 & 0,10 & 0,15 & 0,10 & 0,16 & & & & & \\
\hline $\begin{array}{l}\text { 14. Высокопроизводительные } \\
\text { члены команды }\end{array}$ & $-0,18$ & 0,23 & 0,03 & 0,08 & $-0,12$ & $-0,02$ & 0,57 & 0,51 & 0,78 & 0,89 & 0,45 & 0,30 & 0,22 & & & & \\
\hline 15. Разработчик-звезда & $-0,01$ & 0,05 & 0,01 & 0,02 & 0,00 & $-0,01$ & 0,12 & 0,08 & 0,17 & 0,16 & 0,05 & 0,11 & 0,04 & 0,19 & & & \\
\hline 16. Интегрированное производство & 0,01 & 0,16 & 0,09 & 0,10 & $-0,07$ & 0,05 & $-0,01$ & 0,06 & 0,08 & 0,09 & 0,08 & 0,00 & 0,13 & 0,12 & 0,04 & & \\
\hline 17. Средний возраст фирмы & $-0,19$ & 0,13 & 0,01 & 0,15 & $-0,04$ & 0,06 & 0,44 & 0,23 & 0,46 & 0,44 & 0,20 & 0,39 & 0,20 & 0,44 & 0,13 & 0,04 & \\
\hline 18. Количество элементов & $-0,26$ & 0,03 & $-0,11$ & $-0,01$ & $-0,02$ & $-0,02$ & 0,05 & 0,05 & 0,05 & 0,06 & 0,05 & 0,01 & 0,03 & 0,05 & 0,01 & 0,00 & 0,04 \\
\hline
\end{tabular}




\section{Результаты \\ Симуляции}

На рисунке 3 построены распределения разностей между плотностью наблюдаемых сетей и плотностью симулируемых сетей для четырёх сценариев формирования команд. Все четыре графика ясно показывают, что плотность в наблюдаемых командах выше, чем плотность в симулируемых командах. В сценариях, где команды симулируются из коллег по отрасли, ни одна из симулируемых команд не обладала более высокой плотностью сети, чем наблюдаемая команда. В симуляциях, построенных на социальных сетях членов наблюдаемой команды, 7\% симулируемых команд имеют более высокую плотность сети, чем наблюдаемая команда. Для симуляций, построенных на принципах сходства навыков и организации, это значение равно $10 \%$ и $6 \%$ соответственно.
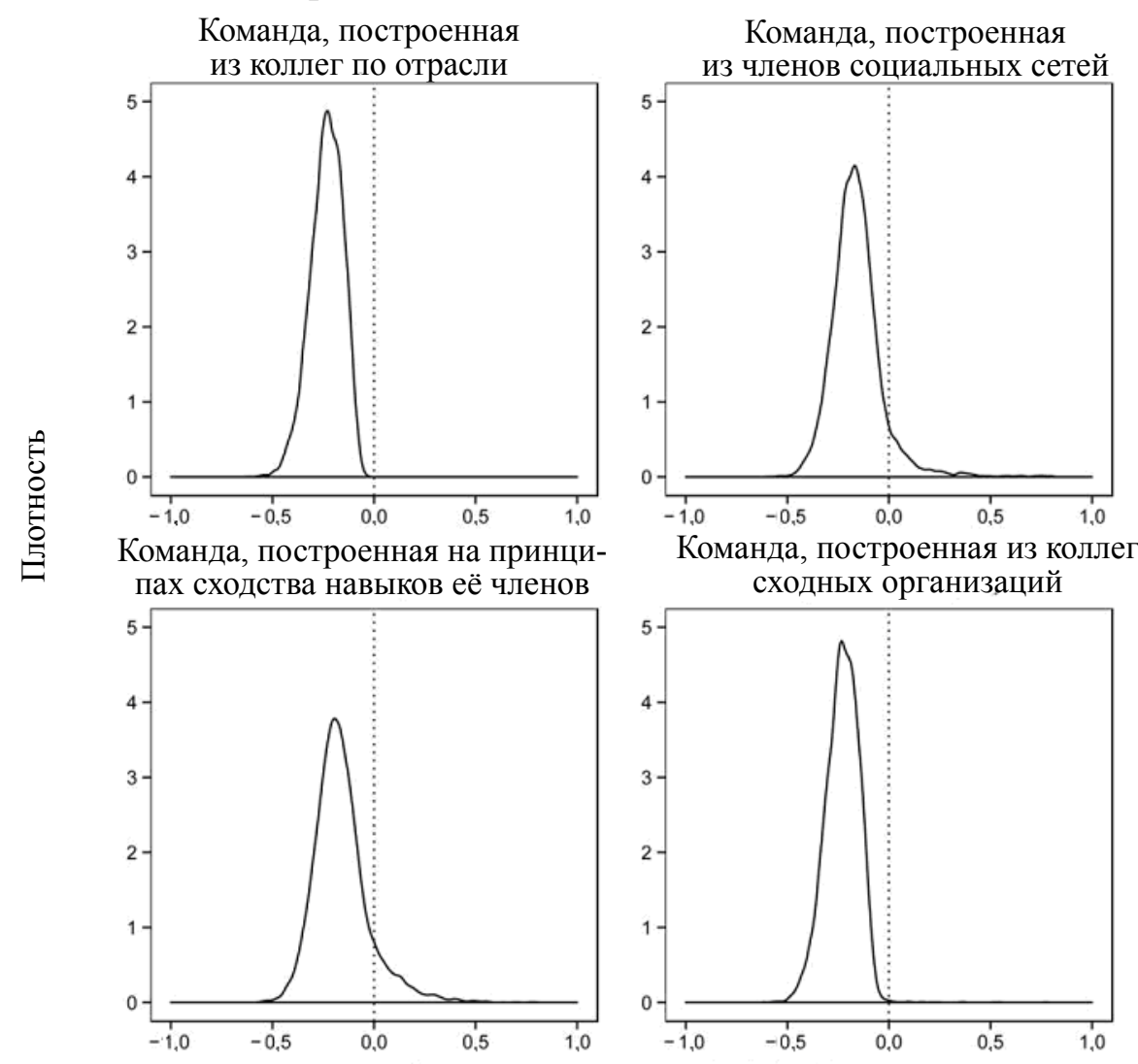

Рис. 3. Разность между плотностью наблюдаемых сетей и плотностью симулируемых сетей

Также мы провели два формальных теста, основанных на этих сравнениях. Первый тест, Колмогорова-Смирнова, проверяет гипотезу о том, что два распределения плотности сети - наблюдаемой и симулированной - являются выборками из разных непрерывных распределений. Нулевая гипотеза состоит в том, что два распределения взяты из одной и той же генеральной совокупности. Полученная статистика и уровень значимости $(\mathrm{P}<0,0001$ для всех четырёх параметров) свидетельствуют о возможности отклонить нулевую гипотезу, и это предполагает, что два распределения наверняка принадлежат разным генеральным совокупностям. Данный вывод справедлив для всех четырёх стратегий симуляции. Второй тест, критерий Уилкоксона, проверяет, различается ли ранг средних в двух переменных. Аналогично тесту Колмогорова-Смирнова, критерий Уилкоксона показывает, что средние имеют разные ранги для данных, полученных из симулированных и из наблюдаемых команд ( $<0,0001$ для всех четырёх параметров).

Мы интерпретируем эти результаты как свидетельство того, что группы, сформированные из тех, кто сотрудничал друг с другом прежде и участвовал в совместных проектах, влияют на процесс набора 
команд. Команды формируются не путём отбора членов исключительно по их индивидуальным качествам, а с учётом предыдущих групповых структур. Это значит, что команды в индустрии видеоигр составлены из групп, а не из отдельных индивидов, и говорит о том, что группы внутри команд узнаваемы и идентифицируемы, а процессы, на которых сфокусированы наши гипотезы, скорее всего, не являются простыми артефактами или следствием ложных взаимосвязей, вызванных тем, что мы не включили какие-то переменные в модели.

История видеоигр - это хроника огромной машины, перемешивающей команды, где песчинками являются подгруппы, малые сообщества, которые содержат память о взаимном доверии и разделяемых смыслах. В день начала проекта по разработке видеоигры такие сообщества погружаются в неудобный зоопарк со множеством незнакомых лиц и теми немногими в структурных складках, кто может помочь связать малые группы в экспериментирующий ансамбль. Таково предположение, которое мы проверяем с помощью регрессионного анализа.

\section{Регрессионный анализ}

В таблице 4 представлены оценки коэффициентов для регрессионных моделей. Зависимой переменной в моделях 1, 2 и 3 является самобытность, зависимой переменной в моделях 4, 5 и 6 - признание критиков, в моделях 7, 8 и $9-$ игра-событие. Первые модели для каждой зависимой переменной включают контрольные переменные, которые описывают размер команды, прошлые достижения их членов и две характеристики фирмы. Во второй набор моделей (модели 2, 5 и 8) мы включили некоторые переменные, характеризующие группы в команде и социальные сети в команде. Наконец, в моделях 3, 6 и 9 показаны оценки для полных моделей, которые включают интересующую нас переменную пересекающееся разнообразие. Сначала мы обсудим результаты для пересекающегося разнообразия, а затем полностью, шаг за шагом, опишем наши модели, интерпретируя коэффициенты и выделяя яркие альтернативные объяснения.

Когнитивные складки являются предиктором самобытности, и их влияние значимо больше нуля. Самобытные игры рождаются из продуктивного напряжения между когнитивно удалёнными, но социально пересекающимися группами. То же самое относится к модели, оценивающей признание критиков как функцию пересекающегося разнообразия. Пересекающееся разнообразие является предиктором для успеха у критиков, что предполагает, что команды, для которых характерно когнитивное напряжение между группами, образующими структурную складку, с большей вероятностью будут производить высоко оцениваемые критиками игры. Когда мы изучаем признание критиками инноваций (выделяться среди других и быть выдающимся), то есть когда мы рассматриваем настоящие игры-события, а не просто успех, рождённый благодаря постепенным изменениям, мы видим, что пересекающееся разнообразие является положительным и статистически значимым предиктором. Игры-события чаще разрабатываются командами, которые состоят из когнитивно непохожих групп (подгруппы с различным когнитивным багажом), допускают и используют множественное членство в таких группах.

Самобытность является зависимой переменной в моделях 1, 2 и 3. Она отражает степень, в которой игра особенна по комбинации своих черт в сравнении с остальными видеоиграми за пять предыдущих лет. Модель 1 представляет базовую модель, а в модель 2 добавлены переменные сетевой структуры структурные складки, ограничения, размер группы и число групп. Модель 2 показывает, что усиление структурных складок между группами - положительный и значимый предиктор для самобытности разработанной игры.

В модель 3 добавлены переменные, описывающие когнитивную композицию команды, - пересекающеееся разнообразие и когнитивное разнообразие. Эта модель показывает, что если учитывать когни- 
тивную дистанцию, которая находится на пересечении групп в команде, то основной эффект от структурных складок становится незначимым. Тем не менее коэффициент пересекающегося разно-образия является положительным и значимым. Кроме того, $F$-тест структурных складок и пересекающегося разнообразия $(P<0,01)$ показывает, что эти переменные совместно значимы. Такие результаты подразумевают, что команды с пересекающимися когнитивно непохожими группами, как правило, разрабатывают более самобытные видеоигры. Как мы предполагали, продуктивное напряжение внутри команд позволяет разрабатывать эксклюзивные продукты. Сами по себе ни образующая пересечения социальная структура, ни когнитивная дистанция не усиливают создание самобытной видеоигры, а способна на это лишь образующая пересечения структура когнитивно отдалённых групп.

Теперь рассмотрим другие переменные, включённые в эту модель, и обсудим, как эти переменные проливают дополнительный свет на производство самобытных видеоигр. Данные контрольные переменные были включены в модели для минимизации риска ошибочно отвергнуть нулевую гипотезу, что пересекающееся разнообразие не оказывает влияния на самобытность.

Включение когнитивного разнообразия призвано проверить альтернативное объяснение нашего главного результата: пересекающееся разнообразие отражает когнитивные различия между членами команды независимо от социальных структур. Модель 3 показывает, что, хотя когнитивное разнообразие позитивно и значимо связано с самобытностью видеоигры, коэффициент при пересекающемся разнообразии положителен и значим. Это значит, что две переменные отражают различные характеристики команд разработчиков видеоигр, а пересекающееся разнообразие, то есть пересечение когнитивно удалённых групп, не может быть сведено просто к когнитивному разнообразию в команде.

Второе альтернативное объяснение положительного и значимого влияния пересекающегося разнообразия на самобытность состоит в том, что пересекающееся разнообразие отражает групповую сплочённость, и эта сплочённость позволяет производить более-менее самобытные видеоигры. Возможно, что пересекающееся разнообразие просто отражает выгоды от наличия больших сплочённых групп, большего числа групп и возросшей плотности в результате обширных пересечений между этими группами. Ограничения способны добавить ещё одно альтернативное объяснение: вариации в пересекающемся разнообразии могут быть связаны с благотворной деятельностью индивидуальных посредников, являющихся членами многих групп. Такие посредники имеют шанс занять уникальную выгодную позицию и пользоваться ею, собирая вознаграждения за новые идеи. Коэффициент при переменной ограничения показывает, что усиление ограничений (меньше возможностей для посредников) приводит к уменьшению самобытности игры. Этот результат соответствует утверждению Бёрта, что уменьшение возможностей для посредников оборачивается более низким уровнем новизны [Burt 2005]. Модель 3 также показывает, что игра является более самобытной, если команда разработчиков вмещает более широкие сплочённые группы (средний размер групnы), но это влияние падает по мере дальнейшего роста среднего размера групп. Мы интерпретируем этот результат следующим образом: как только группы в команде становятся достаточно большими, их размер позволяет поддерживать внутренний рабочий климат и не допускать креолизации.

Набор дополнительных факторов, относящихся как к зависимой переменной, так и к пересекающемуся разнообразию, включает число групп и число членов команды. Мы внесли их в число контрольных переменных, так как большие команды могут вместить большее разнообразие компетенций и опыта. Одновременно более крупная команда способна вместить больше пересекающихся групп. Модели 1-3 показывают, что команды с меньшим числом разработчиков производят более самобытные видеоигры. Мы объясняем этот результат тем, что небольшие проекты с меньшими бюджетами менее скованны финансовым давлением и более склонны к экспериментированию, тогда как крупные команды с серьёзными бюджетами выбирают более безопасные стратегии и не сильно отклоняются от средних характеристик. 
Оценки коэффициентов при предикторах переменных самобытность,

Таблица 4 признание критиков и игра-событие

\begin{tabular}{|c|c|c|c|c|c|c|c|c|c|}
\hline & \multicolumn{3}{|c|}{ Самобытность } & \multicolumn{3}{|c|}{ Признание критиков } & \multicolumn{3}{|c|}{ Игра-событие } \\
\hline & Модель 1 & Модель 2 & Модель 3 & Модель 1 & Модель 2 & Модель 3 & Модель 1 & Модель 2 & Модель 3 \\
\hline Пересекающееся разнообразие & & & $1,198^{* *}(0,413)$ & & & $2,422^{*}(0,981)$ & & & $0,614^{* *}(0,227)$ \\
\hline Когнитивное разнообразие & & & $2,887^{* * *}(0,505)$ & & & $-5,875^{* * *}(1,382)$ & & & $0,235(0,356)$ \\
\hline Структурные складки & & $0,998^{* *}(0,338)$ & $-0,074(0,523)$ & & $0,904(0,854)$ & $-1,577(1,276)$ & & $0,515 * *(0,199)$ & $-0,057(0,298)$ \\
\hline Ограничение & & $-0,057^{* *}(0,021)$ & $-0,065^{* *}(0,021)$ & & $0,113^{* *}(0,042)$ & $0,131^{* *}(0,042)$ & & $0,019(0,012)$ & $0,018(0,013)$ \\
\hline Средний размер группы ${ }^{2}$ & & $0,000^{* *}(0,000)$ & $-0,001^{* * *}(0,000)$ & & $-0,004^{* * *}(0,001)$ & $-0,003^{*}(0,001)$ & & $-0,001^{*}(0,000)$ & $-0,001^{*}(0,000)$ \\
\hline Средний размер группы & & $0,093^{* * *}(0,020)$ & $0,146^{* * *}(0,022)$ & & $0,302^{* * *}(0,061)$ & $0,193^{* *}(0,066)$ & & $0,051^{* * *}(0,014)$ & $0,058^{* * *}(0,016)$ \\
\hline Число групп & & $0,015(0,013)$ & $0,023(0,013)$ & & $-0,023(0,025)$ & $-0,047(0,025)$ & & $-0,011(0,007)$ & $-0,012(0,007)$ \\
\hline Число членов & $-0,064^{* * *}(0,005)$ & $-0,064^{* * *}(0,007)$ & $-0,071^{* * *}(0,007)$ & $-0,102^{* * *}(0,010)$ & $-0,124^{* * *}(0,014)$ & $-0,113^{* * *}(0,015)$ & $-0,035^{* * *}(0,004)$ & $-0,037^{* * *}(0,005)$ & $-0,038^{* * *}(0,005)$ \\
\hline Число новичков & $0,058^{* * *}(0,010)$ & $0,063^{* * *}(0,011)$ & $0,067^{* * *}(0,011)$ & $0,181^{* * *}(0,019)$ & $0,197^{* * *}(0,021)$ & $0,190^{* * *}(0,021)$ & $0,054^{* * *}(0,006)$ & $0,055^{* * *}(0,006)$ & $0,056^{* * *}(0,007)$ \\
\hline Опыт создания игр & $-0,157^{*}(0,079)$ & $-0,249^{* *}(0,085)$ & $-0,234^{* *}(0,085)$ & $-0,156(0,190)$ & $-0,496^{*}(0,208)$ & $-0,568^{* *}(0,208)$ & $0,029(0,046)$ & $-0,038(0,052)$ & $-0,037(0,052)$ \\
\hline Прошлый балл в отзывах & $2,015^{* * *}(0,004)$ & $2,017^{* * *}(0,004)$ & $2,026^{* * *}(0,004)$ & $0,240^{* * *}(0,014)$ & $0,225^{* * *}(0,015)$ & $0,240^{* * *}(0,015)$ & $0,030^{* * *}(0,006)$ & $0,025^{* * *}(0,006)$ & $0,025^{* * *}(0,006)$ \\
\hline $\begin{array}{l}\text { Высокопроизводительные члены } \\
\text { команды }\end{array}$ & $0,049^{* * *}(0,007)$ & $0,041^{* * *}(0,007)$ & $0,046^{* * *}(0,007)$ & $0,186^{* * *}(0,013)$ & $0,198^{* * *}(0,014)$ & $0,192^{* * *}(0,014)$ & $0,038^{* * *}(0,004)$ & $0,038^{* * *}(0,005)$ & $0,039^{* * *}(0,005)$ \\
\hline Разработчик-звезда & $1,680^{*}(0,781)$ & $1,828^{*}(0,779)$ & $1,722^{*}(0,777)$ & $0,109(1,420)$ & $0,325(1,417)$ & $0,577(1,416)$ & $0,358(0,328)$ & $0,452(0,333)$ & $0,458(0,334)$ \\
\hline Средний возраст фирмы & $2,047^{* * *}(0,012)$ & $2,044^{* * *}(0,012)$ & $2,049^{* * *}(0,012)$ & $0,127^{* * *}(0,028)$ & $0,126^{* * *}(0,028)$ & $0,125^{* * *}(0,028)$ & $0,012(0,007)$ & $0,013(0,007)$ & $0,012(0,007)$ \\
\hline Количество элементов & & & & $0,214^{* * *}(0,026)$ & $0,206^{* * *}(0,026)$ & $0,211^{* * *}(0,026)$ & & & \\
\hline Самобытность & & & & $0,386^{* * *}(0,103)$ & $0,368^{* * *}(0,102)$ & $0,364^{* * *}(0,102)$ & & & \\
\hline Константа & $82,401^{* * *}(0,318)$ & $82,259^{* * *}(0,320)$ & $81,413^{* * *}(0,354)$ & $31,522^{* * *}(2,558)$ & $31,860^{* * *}(2,552)$ & $33,391^{* * *}(2,570)$ & $-4,112^{* * *}(0,420)$ & $24,107^{* * *}(0,414)$ & $24,208^{* * *}(0,446)$ \\
\hline $\mathrm{R}^{2}$ & 0,086 & 0,092 & 0,096 & 0,177 & 0,183 & 0,186 & & & \\
\hline Скорректированный $\mathrm{R}^{2}$ & 0,084 & 0,089 & 0,094 & 0,174 & 0,179 & 0,182 & & & \\
\hline Число наблюдений & 8987 & 8987 & 8987 & 5508 & 5508 & 5508 & 5508 & 5508 & 5508 \\
\hline $\begin{array}{l}\text { Информационный критерий } \\
\text { Акаике (AIC) }\end{array}$ & & & & & & & 4685,736 & 4659,079 & 4654,237 \\
\hline $\begin{array}{l}\text { Байесовский информационный } \\
\text { критерий (BIC) }\end{array}$ & & & & & & & 4811,401 & 4817,814 & 4826,200 \\
\hline Отношение правдоподобия & & & & & & & $-2323,868$ & $-2305,539$ & $-2301,118$ \\
\hline
\end{tabular}

Примечание: все вычисления включают фиктивные переменные года и платформы.

${ }^{*} \mathrm{P}<0.05$

${ }^{* *} \mathrm{P}<0.01$

${ }^{* * *} \mathrm{P}<0.001$ 
Мы включили переменную, которая отражает число новичков, поскольку новые разработчики по определению являются изолированными в сети. Переменная нужна для контроля за тем, что увеличение числа новичков (при $X$ членов группы) связано с уменьшением числа групп в команде. Модели 1-3 показывают, что новички являются значимым положительным предиктором для самобытности. Это может означать, что, хотя мы не изучали когнитивный профиль новичков (поскольку они пока не имеют истории в сфере разработки игр), их реальные профили когнитивно удалены и ценны, это позволяет вновь прибывшим трансформировать свои идеи в самобытные характеристики продукта31. Можно использовать похожую линию аргументации для объяснения отрицательного и значимого коэффициента для опыта создания игр. Команды, в составе которых есть ветераны индустрии, менее склонны производить игры, отклоняющиеся от нормы.

Прошлый успех может сопутствовать когнитивной дистанции, образующей структурные складки. Успешные в прошлом разработчики имеют все шансы быть нанятыми снова, и успешные коллективы, скорее всего, будут держаться вместе. Также они имеют больше шансов создавать самобытные видеоигры (например, за счёт использования заработанной прошлыми успехами легитимности), что позволяет им участвовать в экспериментальных проектах. Аналогично, наличием разработчиков-звёзд и высокопроизводительных членов можно объяснить как необычный продукт, так и структуры сплочённых групп. Мы видим, что прошлый успех приводит к менее самобытным играм, однако команды, привлекающие выдающихся разработчиков (в данном случае они измеряются как по производительным членам, так и по разработчикам-звёздам), чаще создаёт неординарные игры. Это говорит о том, что воздействие фактора легитимности возможно только в том случае, если он преодолевает определённый порог: команды со множеством разработчиков с уровнем выше среднего реже выпускают самобытные игры, тогда как команды с немногими по-настоящему выдающимися разработчиками (и с некоторым количеством тех, кто неважно себя проявил в прошлом) чаще производят творческий продукт.

Последними двумя переменными в моделях 1-3 являются интегрированное производство и средний возраст фирмы. Эти переменные описывают организационную структуру, в которой укоренены команды. Коэффициент при интегрированном производстве показывает, что игры, разработанные и выпущенные одной фирмой, с большей вероятностью станут самобытными, чем игры, произведённые множеством фирм. Интерпретация состоит в том, что при согласовании характеристик и параметров игры двум фирмам приходится искать консенсус, тогда как единственная фирма не ограничена требованиями другой организации. Коэффициент при среднем возрасте фирмы показывает, что если команды укоренены в старых фирмах, производимые ими игры имеют меньше шансов стать неординарными. Мы считаем это свидетельством того, что старые фирмы, завоевавшие себе определённое место в отрасли, менее склонны создавать микроклимат, благоприятный для разработки самобытных игр.

\section{Признание критиков}

В данном разделе мы описываем предикторы признания критиков для тех игр, которые получили рецензии. Хотя признание критиков - важный показатель успеха игры, оно не означает ни неординарность игры, ни её способность изменить расклады в отрасли. Сравним модели 4-6 с моделями, объясняющими самобытность.

Модель 5 является базовой; в модель 6 добавлены переменные сетевой структуры, а в модель 7 переменные, измеряющие когнитивное пространство видеоигр. Как и аналогичный коэффициент, рассчитанный для моделей самобытности, коэффициент при пересекающемся разнообразии положительно и значимо связан с признанием критиков. Это говорит о том, что команды, содержащие со-

31 Возможно, новички внутри команды формируют клику (клики) - именно потому, что они не обладают социальной или когнитивной историей, — и статус новичков позволяет им вбросить свои идеи в пока ещё существующие группы. 
циально связанные группы с различающимися когнитивными профилями, в среднем более способны разрабатывать видеоигры, ценимые экспертами. Напротив, команды, для которых характерно большое когнитивное разнообразие между разработчиками (при низкой социальной сплочённости), производят видеоигры, которые низко оценивают критики. Кроме того, модели 5 и 6 показывают, что более высокие уровни ограничений (сплочённые команды с небольшими возможностями для посредников) в командах позволяют им разрабатывать игры, удовлетворяющие вкусы критиков. Как мы видели в моделях 2 и 3, команды с более высоким уровнем ограничений реже производят самобытные игры. Если рецензенты больше ценят соответствие стандартам, нежели самобытность, то можно заключить, что команды с небольшими возможностями для посредничества лучше приспособлены для разработки игр, соответствующих стандартам. Коэффициенты при самобытности и число элементов в таблице 4 и моделях 4, 5 и 6 позволяют прийти к выводу, что рецензенты действительно ценят игры, которые соответствуют стандартам, но в типовой форме соединяют множество стилистических элементов.

Сообразно с результатами, полученными из модели 3, средний размер группы и он же, возведённый в квадрат, показывают, что команды, состоящие из больших групп, производят признанные критиками игры, но эффект от размера группы выравнивается. Признанные критиками команды также стараются привлекать больше опытных участников: чем больше среднее число игр, над которыми в прошлом работали разработчики, тем выше признание критиков их текущей игры. Более высокий прошльй балл 8 отзывах и большее количество высокопроизводительных членов команды также положительно влияют на получение хороших отзывов, тогда как наличие разработчика-звёзды само по себе не увеличивает баллы в рецензиях на игру. Большое число новичков полезно. Если игра разрабатывается и издаётся одной и той же фирмой, оценки критиков выше. То же самое справедливо для старых фирм: тем из них, кому удалось просуществовать несколько лет, лучше, чем новичкам, удаётся привлекать команды, которые разрабатывают игры, близкие вкусам критиков.

\section{Игры-события}

До сих пор мы анализировали самобытность и критическое признание как функции от набора предикторов, описывающих когнитивную структуру, сетевую структуру и историю деятельности команды. Теперь рассмотрим игры-события: постараемся определить факторы, которые делают игру одновременно и самобытной, и признанной критиками. Такие игры имеют необычную комбинацию свойств и широкое признание критиков.

Как и в предыдущих моделях, начнём с базовой модели 7, затем добавим переменные сетевой структуры (модель 8) и когнитивной дистанции (модель 9). Добавляя переменные сетевой структуры в модель 9, видим, что структурные складки - значимый и положительный предиктор творческого успеха. Это соответствует предыдущим исследованиям о творческом потенциале структурных складок [Vedres, Stark 2010]. Средний размер группь также является положительным предиктором, и мы снова обнаружили, что связь между зависимой переменной и средним размером группы представляет собой по форме перевёрнутую букву $U$.

После добавления переменных когнитивной дистанции в модель 10 мы обнаружили, что пересекающееся разнообразие является значимым и положительным предиктором игры-события, тогда как коэффициент при когнитивном разнообразии - положительным, но незначимо отличается от нуля. После того как мы добавили ещё две переменные, описывающие когнитивный профиль команды, структурные складки оказались незначимым фактором. Из этого следует, что механизм, через который структурные складки благотворно влияют на творческий успех команд в индустрии видеоигр, состоит в обеспечении контактов между когнитивно удалёнными группами. Имеет значение не сама по себе сетевая структура со множеством пересечений, а продуктивное напряжение, которое испытывают пересекающиеся группы, когда их когнитивная оболочка различна. 
Модели 7-9 также показывают, что более малочисленные команды чаще производят игру, которая становится игрой-событием. Этот вывод находит поддержку в недавней статье на сайте destructoid.com, которая называется «More People, More Problems» («Больше людей, больше проблем»), где обсуждается, насколько большие команды разработчиков видеоигр страдают от «недостатка сплочённости» и «принципа "мастер на все руки"», как крупные команды могут разрабатывать игры, которые «дотягиваются до звёзд, но едва ли отрываются от земли» 32.

Аналогично результатам для первых шести моделей, игры-события чаще производятся командами с изрядной долей новичков. Мы также обнаружили, что инновационные игры, признанные критиками, чаще производятся командами, в которых работают люди, имевшие успех в прошлом. Хотя коэффициент при разработчике-звезде является положительным, он незначимо отличается от нуля.

Наконец, мы обнаружили, что игры, производимые командами одной фирмы, чаще становятся играмисобытиями. Уже говорилось о том, что привлечение множества фирм может сделать идеи более тусклыми, потому что нужно добиваться консенсуса. Кроме того, игры, разрабатываемые под эгидой одной фирмы, способны создавать повышенную ответственность за фирму и, следовательно, гарантировать дополнительное финансирование и доступ к лучшим ресурсам.

Отметим, что результаты, представленные в моделях 7-9, основаны на 60-м процентиле, который использовался для построения зависимой переменной игры-события. На рисунке 4 изображены точечные оценки и доверительные интервалы для переменной пересекающееся разнообразие при использовании более узких порогов. График показывает, что хотя точные оценки немного изменяются, направление и уровень значимости остаются стабильными.

\section{Социокогнитивные карты команд разработчиков}

Для иллюстрации результатов, представленных выше, мы разработали метод визуализации как когнитивной дистанции, так и групповых структур, который показывает, как когнитивные различия преодолеваются за счёт структурных складок. Мы построили двумодальные графики групп (тёмные узлы) и их членов (белые узлы), наложив друг на друга две техники визуализации. Во-первых, мы используем матрицу расстояний групповых профилей когнитивных элементов и применяем неметрическое многомерное шкалирование для сведения характеристик групп к двумерному когнитивному пространству. Во-вторых, в анализ членов групп были включены их членские связи с группами. Мы размещали разработчиков, используя алгоритм встроенных источников, который находит оптимальное положение для разработчиков по отношению к их сообществам, остающееся неизменным согласно их координатам в когнитивном пространстве. Полученные диаграммы показывают распространение групп (являются они близкими или удалёнными друг от друга в терминах когнитивных профилей) и сетку социальных связей (соединяют ли они группы, и на какое когнитивное расстояние могут простираться членские связи). На рисунке 5 показаны результаты этой техники двойной визуализации для трёх игр. Когнитивная дистанция между группами измеряется по одинаковой шкале для возможности сравнения графиков.

Большая когнитивная дистанция может быть рискованной в отсутствие сети межгрупповых пересечений. На рисунке 5 команда разрабатывала игру «Ривен» («Riven»), выпущенную в 1997 г. Эта игра была не просто своеобразной, но казалась бессвязной: игра-квест, сюжет которой разворачивается на острове, где разрабатываются секретные технологии, действие происходит в будущем. Игроку нужно собирать незаметно разбросанные подсказки и управлять сложными механическими устройствами, чтобы продвинуться в игре. По-настоящему своеобразной чертой игры было то, что она была не только

32 См. URL: http://www.destructoid.com/aaa-game-development-teams-are-too-damn-big-247366.phtml (обращение: 10 октября 2013). 
двумерной (2D), но и составлена из неподвижных изображений. Игра привлекла небольшую группу фанатов, но многие игроки и критики были шокированы фотографическим геймплеем и трудностью головоломок. Иными словами, это была игра, требовавшая глубокого погружения и концентрации и при этом предлагавшая графику ниже того уровня, к которому аудитория уже успела привыкнуть к концу 1990-х: «Если вы не хотите обучаться новой числовой системе, копируя символы для дальнейшего использования и решая абстрактные загадки, вам не понравится "Riven"» ${ }^{33}$.

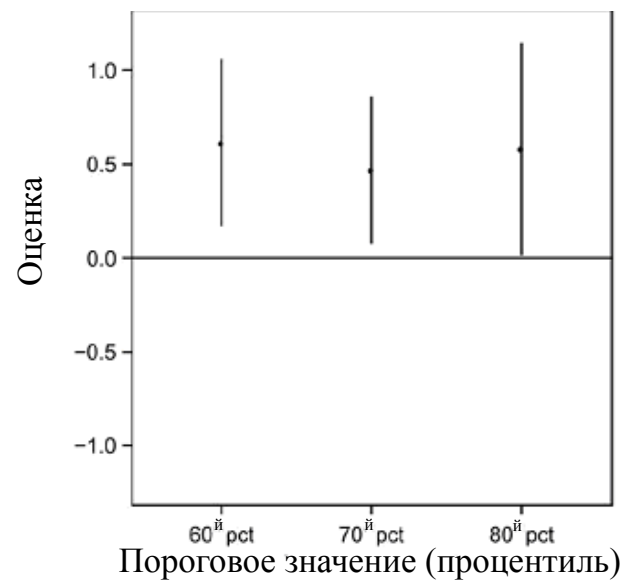

Рис. 4. Оценки коэффциентов и доверительные интервалы для когнитивной складки

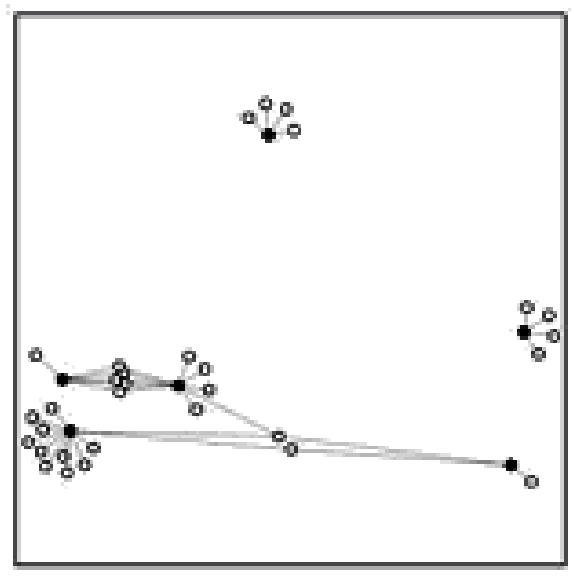

Игра Riven: Sequel to Myst

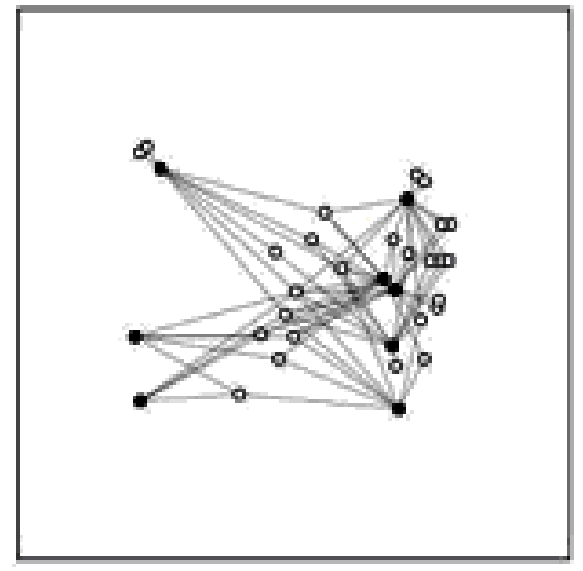

Игра Leisure Suit Larry

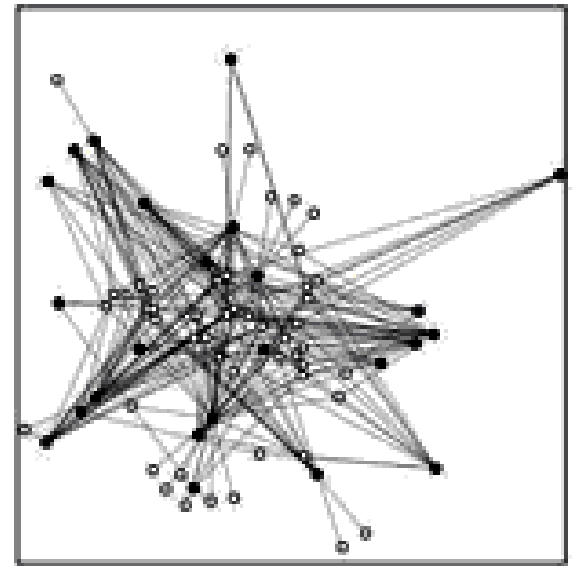

Игра Fallout

Рис. 5. Графы когнитивной дистанции между группами для трёх команд разработчиков игр

Группы пришли из когнитивно разнородных проектов и были слабо связаны друг с другом. Наибольшая когнитивная дистанция из всех структурных складок между группами была у разработчиков игры про подводные лодки («Wolfpack») и приключенческой игры, действие которой происходит в зале суда («In the 1stDegree»). В иных случаях команда состояла из групп, разрабатывавших игры про автогонки, квесты и 2D ролевые игры.

Хотя слишком большая когнитивная дистанция без социальной сплочённости может угрожать успеху игрового проекта, противоположная социокогнитивная структура также таит в себе риски. Секция 2 рисунка 5 показывает команду с высокой сплочённостью, но когнитивно похожими разработчиками. Такая сплочённость без достаточной когнитивной дистанции приводит к зашоренности. Это пример команды, чья разработка провалилась: их ролевую игру большинство рецензентов посчитали скучной, с повторяющимися диалогами и вымученным юмором. Ролевая игра, сюжет которой помещён в инду-

33 Just Games Retro; URL: http://justgamesretro.com/win/riven-the-sequel-to-myst (обращение 22 октября 2013 г.). 
стрию фильмов для взрослых, могла показаться хорошей идеей для команды разработчиков, зацикленной на однотипном юморе (таком, как в серии игр «Worms», где помещённые на двумерный ландшафт с видом сбоку беспозвоночные стараются взорвать друг друга). Хотя разработчики сотрудничали друг с другом в различных проектах - было несколько пересекающихся сообществ, - недостаток продуктивного напряжения, создаваемого когнитивной дистанцией, помешал успеху. «"Leisure Suit Larry: Box Office Bust" - это помойная яма, состоящая из сквернословия и уродливых персонажей. Отвратительный геймплей чрезмерно растянут на часы и часы ненужных, повторяющихся квестов. Эта игра будет плохим приобретением, даже с предложенной скидкой» ${ }^{34}$.

Третья секция рисунка 5 показывает настоящую игру-событие, игру, которая создала свою собственную категорию: «Fallout» («Выпадение реактивных осадков», 1997 г.). Помещённая в «постапокалиптический мир после ядерной войны», эта игра была первой, где ролевая игра и квест были в открытом игровом мире. Почти все предыдущие ролевые игры происходили в средневековой фантазийной среде (подземелье) и вели игрока по жёстко установленному сюжету. В «Fallout» игрок мог свободно бродить по местности и выполнять части миссий в разном порядке либо завоёвывать награды, которые необязательно нужны для прохождения миссии. Команда разработчиков состояла из множества групп, каждая из которых обладала своим уникальным опытом. Большая когнитивная дистанция между этими группами сопровождалась множеством складок. Разработчики могли сотрудничать с носителями навыков и традиций шутеров, ролевых игр, квестов, стратегий реального времени. Группы с опытом создания 2D-, 3D-игр, игр от первого или третьего лица были собраны воедино членами, входящими в структурные складки. Мы полагаем, что групповая структура смогла обратить какофонию в продуктивное напряжение. «"Fallout” - это настоящий "Война и мир” игрового мира: редкий драгоценный камень, бессмертное художественное произведение и перечень героев, за которыми трудно уследить без составления базы данных» ${ }^{35}$.

\section{Заключение}

\section{Oт труб и призм к инструментам и напряжению}

Обобщая соображения о работе социальных сетей, Джоэл Подольны предположил, что связи между социальными акторами одновременно служат в качестве труб, через которые перетекает информация, и в качестве призм, позволяющих человеку оценивать и делать выводы о качестве и надёжности других [Podolny 2001]. Хотя обнаружение этих механизмов, которые превращают отношения между социальными акторами в важную единицу анализа, продвинуло социологию как дисциплину, предложив базовые знания о том, как социальная структура направляет действие, результаты нашего анализа свидетельствуют, что это не единственные механизмы, с помощью которых социальные сети становятся эффективными. Кроме выполнения функций труб и призм, сетевые связи являются источником инструментов и напряжения.

Инструменты. Представленные здесь результаты говорят о том, что репертуар (или портфель) стилей и навыков, приобретённых членами команд по созданию видеоигр за свою карьеру, позволяет им обозначать контуры продукта и устанавливать границы решаемых при его создании и производстве задач. Например, наш анализ показал, что команды, составленные из стилистически разнородных индивидов (то есть суммарный коэффициент когнитивного разнообразия на групповом уровне), чаще производят самобытные видеоигры и реже - игры, понравившиеся критикам. Мысль о том, что репертуар стилей направляет действие, соотносится с тем, как понимает культуру Э. Свидлер [Swidler 1986].

34 GameSpot; URL: http://www.gamespot.com/leisure-suit-larry-box-office-bust/reviews/leisuresuit-larry-box-office-bustreview-6207462/ (обращение 22 октября 2013 г.).

35 Inside Mac Games; URL: http://www.insidemacgames.com/reviews/view.php?ID=299\&Page=4 (обращение 22 октября 2013 г.). 
Позднейшие работы по социологии культуры развили понимание культуры Свидлер [Swidler 1986], указывая на отношенческий базис культурных ящиков с инструментами. Н. Элиасоф и П. Лихтерман, например, переопределили культуру в действии как культуру во взаимодействии [Eliasoph, Lichterman 2003]. Вместо того чтобы описывать ящики с инструментами, содержащие навыки и привычки, как принадлежащие индивиду, они настаивают, что настоящим владельцем ящиков с инструментами является группа. Взаимодействие и коммуникация внутри групп оформлены «разделяемыми всеми постулатами о том, что является хорошим или адекватным участием в жизни группы» [Eliasoph, Lichterman 2003: 737]. Источник этих разделяемых постулатов — серия растянутых во времени взаимодействий, в ходе которых согласовывались значения (иногда явно, а иногда неявно) и возникал групповой стиль. В более поздней работе Энн Свидлер разделяет это определение: «Культурные значения организуются и возникают на коллективном и социальном, а не на индивидуальном уровне» [Swidler 2008: 617].

Как теория, так и эмпирическая стратегия, разработанные в данной статье, начинаются с утверждения, что стили и навыки становятся значимыми элементами в творческой деятельности, когда они создаются, поддерживаются и принимаются группами, а не индивидами. Придерживаясь определения культуры как созданного репертуара навыков и стилей, мы задаёмся вопросом: каким образом группы разработчиков видеоигр используют культуру в своей повседневной рабочей деятельности?

Несмотря на то что новые исследования под влиянием Свидлер сформировали дискуссию об определении культуры и её роли в повседневной жизни, эта литература по-прежнему умалчивает о том, как культура эволюционирует. Например, хотя утверждение, что «инструменты обеспечивают людей < ..> общим языком, на котором думают и говорят» [Eliasoph, Lichterman 2003: 743], сообщает нам о том, как культуру используют внутри групп, мы почти ничего не знаем о том, что происходит, когда группам с разнылми наборами инструментов приходится взаимодействовать. Наши результаты свидетельствуют о том, что исходной точкой при ответе на вопросы о том, как эволюционирует культура, является внимание к символам и стилям, которые определяют границы групп. Это формирует основу для анализа различных групп, пересекающихся в социальном пространстве. В попытке понять сети как источник инструментов мы пришли к выводу, что сетевые связи, сформированные за время карьеры, обеспечивают группам доступ к инструментам, и характер межгруппового взаимодействия в рамках команды формирует направления эволюции инструментов.

Напряжение. Случаи, когда разные группы встречаются, пересекаются и каждая из этих групп обладает собственным групповым стилем, могут привести к неловким и малопродуктивным ситуациям. Большинство из нас могут вспомнить такие дни рождения или свадьбы, на которые были приглашены множество групп друзей и родственников. Напряжения - иногда сильные и непреходящие, - вызванные различиями в групповых стилях, могут испортить праздник, который иначе бы удался, и усугубить различия между группами. Подобные ситуации встречаются в разнообразных сферах, включая научные конференции, крупные департаменты корпораций, спортивные команды, и даже в общественных районных мероприятиях. Нередко считается, что такие напряжения приводят к негативным последствиям, и их не приветствуют, а избегают. В отличие от такого интуитивного понимания напряжения, в данной статье показано, как напряжение может стать продуктивным.

Словосочетание «беспрепятственные потоки информации» является, безусловно, одним из главных претендентов на звание наиболее распространённого выражения о групповом успехе. Это выражение настолько нам знакомо, что мы с трудом можем представить себе замену прилагательного «беспрепятственный» для обратного утверждения: например, «турбулентные потоки информации», «бурные потоки» или «вихревые потоки» звучат чуждо. В противном случае, когда потоки не беспрепятственные (или, по крайней мере, не спокойные), предполагается, что потоки информации нарушаются. Также 
как «разногласие» было проблемой, преодолеваемой «сниженными трансакционными издержками» в рамках экономической теории [Williamson 1981], целью значительной части литературы по сетевому анализу является обнаружение структур, которые усиливают передачу информации в беспрепятственных потоках [Coleman 1988; Borgatti, Cross 2003].

В этой попытке сетевой анализ имеет много общего с постоянной озабоченностью социологии в целом изучением основ социетального порядка, социальной гармонии и координированного действия. Стандартный социологический рецепт здесь долгое время состоял в чём-то вроде взаимного понимания или разделяемого понимания, а главными составляющими являлись нормы, стили и привычки, которые разделялись всеми. Информация течёт. Ценности разделяются. Иногда в основе разделения ценностей находятся сетевые каналы общения; а иногда информация течёт по установленным каналам разделяемых ценностей. Для одних беспрепятственные трансакции укоренены в социальных связях [Borgatti, Cross 2003], для других - в разделяемых культурных элементах [Portes, Sensenbrenner 1993; Eliasoph, Lichterman 2003]. Однако, кажется, мало кто сомневается в том, что когда что-то происходит беспрепятственно, оно становится лучше. Диссонанс, как и конфликт, может поднимать свою буйную голову, но это препятствует координации и может быть решено согласно принципу народной социологии: «Если бы мы могли просто собраться все вместе и сгладить все различия».

В то время как примеры негативных последствий непреодолимых различий многочисленны, другое направление подчёркивает важность тех выгод, которые дают различия. Тезис состоит в том, что различия, представленные как разнообразие, показывают свою другую сторону, так как разнообразие это положительное качество, и организации могут выдержать значительный его уровень, обеспечив основные разделяемые ценности, в том числе приверженность к ценности разнообразия. В этой аргументации тем не менее не находится места признанию важной роли групп. Если групповые стили внутренне гомогенны, но гетерогенны между группами, как тогда эти группы совместно используют имеющиеся в их распоряжении элементы культуры? В данной статье утверждается, что культурные элементы, которыми обладают члены команды, приносят наибольшую пользу, когда группы, обладающие этими стилями и навыками, пересекаются в социальном пространстве. Позиция структурной складки на пересечении множества групп позволяет находящимся там акторам создавать продуктивные, а не разрушительные напряжения.

В своём исследовании мы обнаружили, что команды в отрасли видеоигр составлены из групп. Кроме того, наш анализ показал, что творческий успех становился больше, когда когнитивно удалённые группы пересекались в социальном пространстве. Да, что-то должно разделяться всеми. Однако это необязательно должно быть взаимное понимание. В предложенной нами динамике социальные пересечения между группами не сразу снимают напряжение или ведут к мгновенному пониманию. Они конструируют рабочее пространство, где определённое непонимание вполне терпимо в интересах создания нового креола, который может преодолеть ограничения взаимно непереводимого. Вслед за русским семиотиком Юрием Лотманом и американским представителем философии прагматизма Чарльзом Сандерсом Пирсом (см. также: [Stark 2009: 190-195]) мы пришли к результатам, которые говорят о том, что непонимание в коммуникации может быть не менее важным, чем успешная передача. Как пишет Лотман, «непонимание (разговор на не полностью идентичных языках) представляется столь же ценным смысловым механизмом, что и понимание» [Lotman 2009: хxiii] ${ }^{36}$. В противоположность образу беспрепятственно текущей информации (характеристика модели передачи), процесс пересекающегося разнообразия - это хаотичный процесс. Хотя стили могут казаться порой несопоставимыми, структурные складки позволяют сделать различия не разрушительными, а созидательными.

36 Цит. по: Лотман Ю. М. 1992. Культура и взрыв. М.: Гнозис; 16. - Примеч. ред. 


\section{Приложение A}

\section{Регрессионные модели с фиксированными эфффектами издателя}

Команды, производящие видеоигры, могут быть оформлены как временные организации, которые распадаются, как только заканчивается проект. Команды также могут быть организованы в рамках одной или нескольких фирм. В некоторых случаях к проекту по созданию видеоигры привлечена только одна формальная организация, которая ответственна как за разработку игры, так и за её издание; в других случаях к проекту привлекаются издатель и разработчик. Начиная с середины 1980-х гг. около 50\% игр производились единственной фирмой, и ещё 50\% игр - несколькими фирмами. В нашей базе данных содержатся 1575 фирм (1385 разработчиков и 190 издателей), которые создали или издали видеоигру. Чтобы учесть эту организационную характеристику отрасли и исключить возможность того, что наши результаты окажутся следствием одного или более возмущающих факторов стабильных на уровне фирмы, мы рассчитали модели 3, 6 и 9, зафиксировав эффект фирмы. В таблице ПА.1 представлены модели, где зафиксирован издатель. Мы также экспериментировали с моделями, где зафиксирован разработчик, но, хотя результаты остаются стабильными, множество наблюдений были исключены из анализа, потому что отсутствовала внутрифирменная вариация.

Таблица ПА.1

Оценки коэффициентов на основе моделей с фиксированными эффектами издателя

\begin{tabular}{|c|c|c|c|}
\hline Переменная & $\begin{array}{c}\text { Самобытность } \\
\text { Модель } 10\end{array}$ & $\begin{array}{c}\text { Признание критиков } \\
\text { Модель } 11\end{array}$ & $\begin{array}{c}\text { Игра-событие } \\
\text { Модель } 12\end{array}$ \\
\hline Пересекающееся разнообразие & $1,266^{* *}(0,423)$ & $2,732^{* *}(1,022)$ & $0,783^{* *}(0,258)$ \\
\hline Когнитивное разнообразие & $1,908^{* * *}(0,549)$ & $-5,975^{* * *}(1,485)$ & $0,078(0,406)$ \\
\hline Структурные складки & $-0,362(0,531)$ & $-2,238(1,322)$ & $-0,348(0,336)$ \\
\hline Ограничение & $-0,080^{* * *}(0,021)$ & $0,099 *(0,042)$ & $0,004(0,014)$ \\
\hline 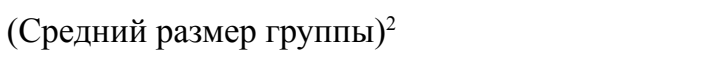 & $0,000^{* *}(0,000)$ & $-0,004^{* *}(0,001)$ & $0,000(0,000)$ \\
\hline Средний размер группы & $0,100^{* * *}(0,023)$ & $0,243^{* * *}(0,069)$ & $0,052^{* *}(0,018)$ \\
\hline Число групп & $0,012(0,013)$ & $-0,034(0,026)$ & $-0,009(0,008)$ \\
\hline Число членов & $-0,060^{* * *}(0,007)$ & $-0,084^{* * *}(0,014)$ & $-0,035^{* * *}(0,005)$ \\
\hline Число новичков & $0,053^{* * *}(0,011)$ & $0,152^{* * *}(0,021)$ & $0,052^{* * *}(0,007)$ \\
\hline Опыт создания игр & $-0,214^{*}(0,091)$ & $-0,824^{* * *}(0,220)$ & $-0,073(0,060)$ \\
\hline Прошлый балл в отзывах & $-0,013^{* *}(0,005)$ & $0,194^{* * *}(0,017)$ & $0,011^{*}(0,005)$ \\
\hline Высокопроизводительные члены команды & $0,040^{* * *}(0,007)$ & $0,157^{* * *}(0,014)$ & $0,036^{* * *}(0,005)$ \\
\hline Разработчик-звезда & $0,916(0,750)$ & $-0,476(1,376)$ & $0,182(0,341)$ \\
\hline Самобытность & & $0,192^{* * *}(0,027)$ & \\
\hline Число элементов & & $0,429^{* * *}(0,103)$ & \\
\hline Константа & $87,017^{* * *}(1,633)$ & $45,577^{* * *}(5,980)$ & $-2,314(1,237)$ \\
\hline $\mathrm{R}^{2}$ & 0,243 & 0,295 & \\
\hline Скорректированный $\mathrm{R}^{2}$ & 0,200 & 0,258 & \\
\hline Число наблюдений & 8652 & 5318 & 5318 \\
\hline Информационный критерий Акаике (AIC) & & & 4568,947 \\
\hline Байесовский информационный критерий (BIC) & & & 6292,606 \\
\hline Отношение правдоподобия & & & $-2022,473$ \\
\hline
\end{tabular}

Примечание: все три модели включают фиктивные переменные года, платформы и фирмы.

$* \mathrm{P}<0,05$.

$* * \mathrm{P}<0,01$.

$* * * \mathrm{P}<0,001$.

Зависимой переменной в модели 10 является самобытность, она дублирует модель 3 и фиксирует издателя. Модель 11 дублирует модель 6 (признание критиков), а модель 12 (игры-события) дублирует модель 9; в обоих случаях зафиксирован издатель. Результаты для наших основных независимых 
переменных остались стабильными. Как и для моделей, представленных в таблице 2, модели 10, 11 и 12 показывают, что пересекающееся разнообразие имеет положительную связь с самобытностью, признанием критиков и играми-событиями. Направление и значимость коэффициентов при пересекающемся разнообразии также стабильны. Подобно исходным моделям, представленным в таблице 2 , структурные складки имеют обратную связь с нашими тремя зависимыми переменными, но ни один из коэффициентов не отличается значимо от нуля.

В итоге представленные в статье результаты не становятся иными при изменении спецификации наших моделей с общих на фиксированные. Это говорит о том, что вряд ли часть дисперсии зависимых переменных можно объяснить с помощью исключённых переменных, стабильных на уровне фирмы и коррелируемых с нашими основными объясняющими переменными.

\section{Приложение Б}

\section{Регрессионные модели с коррекцией выборки}

Две из трёх зависимых переменных - критическое признание и игры-события - фиксировались лишь на подвыборке из всех видеоигр в нашей выборке. Всего 5508 видеоигр из всех 8987 были отрецензированы в отобранных источниках, а 3479 игр рецензий не получили. Последствия этих расхождений могут быть серьёзными как с содержательной, так и с методологической точки зрения.

Во-первых, разработка игры с новыми качествами является лишь одной из стадий на пути к творческому успеху. Чтобы игру включили в соревнование за признание критиков, она должна быть прежде всего замечена в профессиональном поле игровой журналистики как что-то, достойное внимания. Говоря проще, будет ли новая видеоигра рецензироваться в принципе? Полное исключение из процесса оценки куда как хуже, чем просто несоответствие ожиданиям критиков.

Во-вторых, следствием из несоответствия между числом игр и числом отрецензированных игр является то, что смещение выборки может испортить наши основные выводы. Это смещение может возникнуть, если отрецензированные видеоигры не репрезентируют массив всех видеоигр в выборке. Например, видеоигры, разработанные низкоквалифицированными командами, вряд ли окажутся в числе рецензируемых видеоигр. Тем не менее некоторые из таких игр, разработанные низкоквалифицированными командами, получили рецензии. Такие исключения, возможно, проистекают из одной или множества неизмеренных характеристик, таких как наличие в команде высокопрофессионального маркетолога. В результате видеоигры, разработанные низкоквалифицированными командами и попавшими в выборку отрецензированных, в выборке увеличивают количество наблюдений с большими погрешностями. Проблема состоит в том, что независимо от взаимосвязи качества команды с наличием высококвалифицированного маркетолога (что не измерялось) эти две переменные будут по определению коррелировать в выборке. Если профессиональные маркетологи знают, как сообщать о хорошем качестве игры (а не о его отсутствии) и тем самым побудить критиков написать отзыв об игре, и если профессиональные маркетологи положительно влияют на получаемый игрой балл рецензии, наши оценки воздействия качества команды на признание критиков будут смещены вниз, потому что низкоквалифицированные команды в выборке обладают необычайно классными маркетологами [Sartori 2003] ${ }^{37}$.

Со смещением выборки можно справиться с помощью модели отбора Хекмана [Heckman 1979], которая состоит из двух уравнений. Первое - уравнение отбора - включает все игры в выборке, поскольку оно предназначено для моделирования принятого критиками решения о том, рецензировать

37 Если ошибки в двух уравнениях коррелируют между собой, то средняя ошибка итогового уравнения будет отлична от нуля, а сам остаточный член будет коррелировать с объясняющей переменной. Это нарушает предпосылку экзогенности [Sartori 2003]. 
игру или нет. Мы используем бинарную зависимую переменную - получение рецензии, — которая описывает, имеет игра рецензии или нет. Выборка во втором уравнении состоит лишь из тех игр, которые получили рецензии. Коэффициенты в модели Хекмана могут быть рассчитаны путём последовательного использования двухшаговой процедуры. На первом шаге рассчитывается уравнение отбора с использованием пробит-регрессии; затем оценки используются для расчёта обратного отношения Миллса. На втором шаге рассчитываются МНК регрессии, которые определяют зависимую переменную как функцию от независимой переменной и рассчитанного отношения Миллса. Очевидно, что наша модель, где переменная игры-события является зависимой, может быть рассчитана с помощью линейной вероятностной модели с использованием МНК. Однако ограниченные модели с зависимой переменной более эффективно рассчитываются с помощью отношения максимального правдоподобия. Следовательно, мы используем адаптированную версию модели отбора Хекмана, которая позволяет получить оценки итоговой переменной с использованием пробит-модели [Sartori 2003].

К моделям отбора Хекмана для обеих наших усечённых переменных - критического признания и игр-событий - применяются те же самые шаги, что и к модели для самобытности. Результаты, представленные в таблице ПБ.1, показывают, что учёт смещения выборки не приводит к изменениям наших основных результатов, описанных в статье ранее. Но поскольку коэффициенты были подсчитаны в новом уравнении, мы кратко обсудим результаты.

Таблица ПБ.1

Оценки коэффициентов на основе моделей с коррекцией выборки

\begin{tabular}{|c|c|c|c|}
\hline Переменная & $\begin{array}{c}\text { Отбор } \\
\text { Модель } 13\end{array}$ & $\begin{array}{c}\text { Признание критиков } \\
\text { Модель } 14\end{array}$ & $\begin{array}{c}\text { Игра-событие } \\
\text { Модель } 15\end{array}$ \\
\hline Пересекающееся разнообразие & & $2,496^{*}(0,981)$ & $0,340 * * *(0,112)$ \\
\hline Когнитивное разнообразие & & $-5,805^{* * *}(1,383)$ & $0,013^{* * *}(0,167)$ \\
\hline Структурные складки & & $-1,599(1,276)$ & $-0,051(0,147)$ \\
\hline Ограничение & & $0,137^{* *}(0,042)$ & $0,014^{*}(0,006)$ \\
\hline$(\text { (редний размер группы })^{2}$ & & $-0,003^{*}(0,001)$ & $-0,000^{*}(0,000)$ \\
\hline Средний размер группы & & $0,205^{* *}(0,067)$ & $0,032^{* * *}(0,008)$ \\
\hline Число групп & & $-0,048(0,025)$ & $-0,008(0,004)$ \\
\hline Число членов & & $-0,115^{* * *}(0,015)$ & $-0,019^{* * *}(0,002)$ \\
\hline Число новичков & & $0,194^{* * *}(0,022)$ & $0,029^{* * *}(0,003)$ \\
\hline Опыт создания игр & & $-0,588 * *(0,209)$ & $-0,032(0,025)$ \\
\hline Прошлый балл в отзывах & & $0,241^{* * *}(0,015)$ & $0,009^{* * *}(0,002)$ \\
\hline Высокопроизводительные члены команды & & $0,192^{* * *}(0,014)$ & $0,020^{* * *}(0,002)$ \\
\hline Разработчик-звезда & $1,138^{* * *}(0,311)$ & $0,939(1,427)$ & $0,397^{*}(0,181)$ \\
\hline Интегрированное производство & $-0,044(0,032)$ & $2,280^{* * *}(0,339)$ & $\left.0,128^{* * *} 0,041\right)$ \\
\hline Средний возраст фирмы & $0,054^{* * *}(0,002)$ & $0,167^{* * *}(0,036)$ & $0,028^{* * *}(0,004)$ \\
\hline Самобытность & $-0,027^{* * *}(, 004)$ & $0,197^{* * *}(0,027)$ & $0,148^{* * *}(0,005)$ \\
\hline Число элементов & $0,037^{* *}(0,011)$ & $0,379^{* * *}(0,103)$ & $0,042^{*}(0,018)$ \\
\hline Константа & $0,504(0,318)$ & $32,791^{* * *}(2,588)$ & $-2,660^{* * *}(0,160)$ \\
\hline $\mathrm{R}^{2}$ & & 0,186 & \\
\hline Скорректированный $\mathrm{R}^{2}$ & & 0,182 & \\
\hline Число наблюдений & 8987 & 5508 & 5508 \\
\hline Информационный критерий Акаике (AIC) & 9759,753 & & $13,219,65$ \\
\hline Байесовский информационный критерий (BIC) & 10107,827 & & $13,766,62$ \\
\hline Отношение правдоподобия & $-4830,877$ & & $-6,532,824$ \\
\hline
\end{tabular}

Примечание: модель 13 включает фиктивные переменные года, платформы, жанра и страны. Модели 14 и 15 включают только фиктивные переменные года и платформы.

$* \mathrm{P}<0,05 ; * * \mathrm{P}<0,01 ; * * * \mathrm{P}<0,001$. 
Результаты оценок представлены в модели 13. Мы обнаружили, что как возраст фирмы, так и наличие разработчика-звезды являются значимыми предикторами. Команды, обладающие звездой и работающие на более возрастную фирму, чаще производят игры, получающие отзывы критиков, что говорит о том, что репутация обеспечивает вход в зону рецензирования и оценивания. Результаты также показывают: чем более игра сложна и богата характеристиками (что измеряется количеством элементов), тем более вероятно, что её отрецензируют. Самобытность игры, однако, имеет отрицательную зависимость с вероятностью получить отзыв критиков. Чем более игра отклоняется от нормы (возможно, до уровня, когда её будет трудно отнести к какой-либо категории), тем меньше шансов, что она попадёт на стол к критикам. Это подчёркивает риск выделения из толпы - слишком отличаясь от игр, образующих норму, продукт становится менее узнаваемым и поэтому исключается даже из списка рецензируемых.

\section{Литература}

Abbott A. 1999. Department and Discipline: Chicago Sociology at One Hundred. Chicago: University of Chicago Press.

Agresti A., Finlay B. 2009. Statistical Methods for the Social Sciences: Upper Saddle River. N.J.: Pearson Prentice Hall.

Alexander J. C. 2004. Cultural Pragmatics: Social Performance between Ritual and Strategy. Sociological Theory. 22 (4): 527-573.

Aoyama Y., Izushi H. 2003. Hardware Gimmick or Cultural Innovation? Technological, Cultural, and Social Foundations of the Japanese Video Game Industry. Research Policy. 32 (3): 423-444.

Bauer D. F. 1972. Constructing Confidence Sets Using Rank Statistics. Journal of the American Statistical Association. 67: 687-690.

Becker H. S. 1974. Art as Collective Action. American Sociological Review. 39 (6): 767-776.

Bellotti E. 2012. Getting Funded: Multi-Level Network of Physicists in Italy. Social Networks. 34 (2): 215 229.

Berman S., Downs J., Hill C. 2002. Tacit Knowledge as a Source of Competitive Advantage in the National Basketball Association. Academy of Management Journal. 45 (1): 13-31.

Bird A. 1994. Careers as Repositories of Knowledge: A New Perspective on Boundaryless Careers. Journal of Organizational Behavior. 15 (4): 325-344.

Bissell T. 2011. Extra Lives: Why Video Games Matter. New York: Vintage Books.

Borgatti S., Cross R. 2003. A Relational View of Information Seeking and Learning in Social Networks. Management Science 49 (4): 432-445.

Bowker G. C., Star S. L. 2000. Sorting Things Out: Classification and Its Consequences. Cambridge, MA: MIT Press.

Brown J. S., Duguid P. 1991. Organizational Learning and Communities of-Practice: Toward a Unified View of Working, Learning, and Innovation. Organization Science. 2 (1): 40-57. 
Burt R. 1995. Structural Holes: The Social Structure of Competition. Cambridge, Mass.: Harvard University Press.

Burt R. 2004. Structural Holes and Good Ideas. American Journal of Sociology. 110 (2): 349-399.

Burt R. 2005. Brokerage and Closure: An Introduction to Social Capital. New York: Oxford University Press.

Burt R. 2014. Reinforced Structural Holes. Working paper. Booth School of Business, University of Chicago. August.

Carley K. M. 2001. Computational Approaches to Sociological Theorizing. In: Turner J. H. (ed.) Handbook of Sociological Theory. New York: Kluwer Academic/Plenum Publishers; 69-83.

Carnabuci G., Bruggeman J. 2009. Knowledge Specialization, Knowledge Brokerage and the Uneven Growth of Technology Domains. Social Forces. 88 (2): 607-641.

Caves R. 2002. Creative Industries: Contracts between Art and Commerce. Cambridge, MA: Harvard University Press.

Coleman J. 1988. Social Capital in the Creation of Human Capital. American Journal of Sociology. 94: S95S120.

De Nooy W. 2003. Artistic Classifications as Collective Representations. Paper presented at the sixth conference of the European Sociological Association. URL: http://www.uva.nl/binaries/content/documents/ personalpages/n/o/w.denooy/en/tab-one/tab-one/cpitem\%5B98\%5D/asset.

De Vaan M. 2014. Interfirm Networks in Periods of Technological Turbulence and Stability. Research Policy. 43 (10): 1666-1680.

Delmestri G., Montanari F., Usai A. 2005. Reputation and Strength of Ties in Predicting Commercial Success and Artistic Merit of Independents in the Italian Feature Film Industry. Journal of Management Studies. 42 (5): 975-1002.

DiMaggio P. 1997. Culture and Cognition. Annual Review of Sociology. 23: 263-287.

DiMaggio P. 2011. Cultural Networks. In: Scott J., Carrington P. J. (eds) The SAGE Handbook of Social Network Analysis. Three Oaks, Calif.: SAGE Publications; 286-300.

Eco U. 1990. I limiti del interpretazione [The Limits of Interpretation]. Milan: Bompiani.

Eco U. 2001. Introduction to Yuri Lotman. In: Universe of the Mind: A Semiotic Theory of Culture by Yuri Lotman. Bloomington: Indiana University Press; vii-xiii.

Eliasoph N., Lichterman P. 2003. Culture in Interaction. American Journal of Sociology. 108 (4): 735-794.

Evans J. 2010. Industry Induces Academic Science to Know Less about More. American Journal of Sociology. 116 (2): 389-452. 
Ganz M. 2000. Resources and Resourcefulness: Strategic Capacity in the Unionization of California Agriculture, 1959-1966. American Journal of Sociology. 105 (4): 1003-1062.

Gartner. 2011. Market Trends: Gaming Ecosystem. June 10. Gartner, Inc. URL: https://www.gartner.com/ doc/1724014/market-trends-gaming-ecosystem-

Giuffre K. 2001. Mental Maps; Social Networks and the Language of Critical Reviews. Sociological Inquiry. 71 (3): 381-93.

Gould G. 1994. Forgery and Imitation in the Creative Process. Grand Street. 13 (2): 53-62.

Grabher G. 2002. Cool Projects, Boring Institutions: Temporary Collaboration in Social Context. Regional Studies. 36 (3): 205-214.

Grabher G. 2004. Learning in Projects, Remembering in Networks? Communality, Sociality, and Connectivity in Project Ecologies. European Urban and Regional Studies. 11 (2): 103-123.

Grund T. U. 2012. Network Structure and Team Performance: The Case of English Premier League Soccer Teams. Social Networks. 34 (4): 682-690.

Guimera R. et al. 2005. Team Assembly Mechanisms Determine Collaboration Network Structure and Team Performance. Science. 308 (5722): 697-702.

Hargadon A., Bechky B. 2006. When Collections of Creatives Become Creative Collectives: A Field Study of Problem Solving at Work. Organization Science. 17 (4): 484-500.

Heckman J. J. 1979. Sample Selection Bias as a Specification Error. Econometrica. 47 (1): 153-161.

Holland J. 1992. Complex Adaptive Systems. Daedalus. 121 (1): 17-30.

Hutter M. 2011. Infinite Surprises: Value in the Creative Industries. In: Beckert J., Aspers P. (eds) The Worth of Goods: Valuation and Pricing in the Economy. New York: Oxford University Press; 201-220.

Ibert O., Schmidt S. 2012. Acting on Multiple Stages. Raumforschung und Raumordnung. 70 (4): 349-361.

Jacob F. 1977. Evolution and Tinkering. Science. 196 (4295): 1161-1166.

Jaffe A. 1986. Technological Opportunity and Spillovers of R\&D: Evidence from Firms' Patents, Profits, and Market Value. American Economic Review. 76 (5): 984-1001.

Jerolmack C., Khan S. 2014. Talk Is Cheap: Ethnography and the Attitudinal Fallacy. Sociological Methods and Research. 43 (2): 178-209.

Lamont M. 1992. The Dignity of Working Men. Cambridge, MA: Harvard University Press.

Lampel J., Lant T., Shamsie J. 2000. Balancing Act: Learning from Organizing Practices in Cultural Industries. Organization Science. 11 (3): 263-269.

Lester R., Piore M. 2004. Innovation—the Missing Dimension. Cambridge, MA Harvard University Press. 
Lingo E., O’Mahony S. 2010. Nexus Work: Brokerage on Creative Projects. Administrative Science Quarterly. 55 (1): 47-81.

Lopes P. D. 1992. Innovation and Diversity in the Popular Music Industry, 1969 to 1990. American Sociological Review. 57: 56-71.

Lotman Y. 1990. Universe of the Mind: A Semiotic Theory of Culture. Bloomington: Indiana University Press.

Lotman Y. 2009. Culture and Explosion. Berlin: De Gruyter Mouton.

Mizruchi M. 1996. What Do Interlocks Do? An Analysis, Critique, and Assessment of Research on Interlocking Directorates. Annual Review of Sociology. 22: 271-298.

Mohr J. W. 1994. Soldiers, Mothers, Tramps, and Others: Discourse Roles in the 1907 New York City Charity Directory. Poetics. 22: 327-357.

Obstfeld D. 2005. Social Networks, the Tertius Iungens Orientation, and Involvement in Innovation. Administrative Science Quarterly. 50 (1): 100-130.

Owen-Smith J., Powell W. W. 2004. Knowledge Networks as Channels and Conduits: The Effects of Formal Structure in the Boston Biotechnology Community. Organization Science. 15 (1): 5-21.

Pachucki M. A., Breiger R. L. 2010. Cultural Holes: Beyond Relationality in Social Networks and Culture. Annual Review of Sociology. 36: 205-224.

Peterson R. A., Berger D. G. 1971. Entrepreneurship in Organizations: Evidence from the Popular Music Industry. Administrative Science Quarterly. 16 (1): 97-106.

Podolny J. M. 2001. Networks as the Pipes and Prisms of the Market. American Journal of Sociology. 107: $33-60$.

Poincaré H. (1908) 1985. Papers on Fuchsian Functions. Berlin:Springer-Verlag.

Portes A., Sensenbrenner J. 1993. Embeddedness and Immigration: Notes on the Social Determinants of Economic Action. American Journal of Sociology. 98 (6): 1320-1350.

Reagans R., McEvily B. 2003. Network Structure and Knowledge Transfer: The Effects of Cohesion and Range. Administrative Science Quarterly. 48 (2): 240-267.

Rowlinson M. et al. 2010. Social Remembering and Organizational Memory. Organization Studies. 31 (1): 69-87.

Ruef M., Aldrich H., Carter N. 2003. The Structure of Founding Teams: Homophily, Strong Ties, and Isolation among U.S. Entrepreneurs. American Sociological Review. 68 (2): 195-222.

Sartori A. 2003. An Estimator for Some Binary-Outcome Selection Models Without Exclusion Restrictions. Political Analysis. 11: 111-138. 
Schumpeter J. 2012. Capitalism, Socialism and Democracy. London: Routledge.

Sewell W. F. 1992. A Theory of Structure: Duality, Agency, and Transformation. American Journal of Sociology. 98 (1): 1-29.

Simmel G. 1955 (1922). Conflict and the Web of Group Affiliations (trans., ed. by K. Wolff). Glencoe, Ill.: Free Press.

Sohn M.-W. 2001. Distance and Cosine Measures of Niche Overlap. Social Networks. 23 (2): 141-165.

Stark D. 2009. The Sense of Dissonance: Accounts of Worth in Economic Life. Princeton, N.J.: Princeton University Press.

Swidler A. 1986. Culture in Action: Symbols and Strategies. American Sociological Review. 51 (2): 273286.

Swidler A. 2008. Comment on 'Socrates, Skinner, and Aristotle: Three Ways of Thinking About Culture in Action’ by Stephen Vaisey. Sociological Forum. 23 (3): 614-618.

Tschang T. 2007. Balancing the Tensions between Rationalization and Creativity in the Video Games Industry. Organization Science. 18 (6): 989-1005.

Uzzi B., Spiro J. 2005. Collaboration and Creativity: The Small World Problem. American Journal of Sociology. 111 (2): 447-504.

Vedres B., Stark D. 2010. Structural Folds: Generative Disruption in Overlapping Groups. American Journal of Sociology. 115 (4): 1150-1190.

Wegner D. M. 1995. A Computer Network Model of Human Transactive Memory. Social Cognition. 13: $1-21$.

Weitzman M. 1998. Recombinant Growth. Quarterly Journal of Economics. 113 (2): 331-360.

Williamson O. E. 1981. The Economics of Organization: The Transaction Cost Approach. American Journal of Sociology. 87 (3): 548-577.

Wuthnow R. 1987. Meaning and Moral Order: Explorations in Cultural Analysis. Berkeley and Los Angeles: University of California Press.

Zerubavel E. 1997. Social Mindscapes: An Invitation to Cognitive Sociology. Cambridge, Mass.: Harvard University Press.

Zuckerman E. 1999. The Categorical Imperative: Securities Analysts and the Illegitimacy Discount. American Journal of Sociology. 104 (5): 1398-1438. 


\title{
NEW TRANSLATIONS
}

\author{
Mathijs de Vaan, Balazs Vedres, David Stark
}

\section{Game Changer: The Topology of Creativity}

\author{
DE VAAN, Mathijs - Assistant \\ Professor of Management of \\ Organizations, Haas School of \\ Business, University of California \\ at Berkeley. Address: Berkeley, CA \\ 94720-1900, USA.
}

Email: mdevaan@haas.berkeley.edu

VEDRES, Balazs - Associate Professor, Department of Sociology and Social Anthropology; Director, Center for Network Science, Central European University. Address: 9 Nador utca, Budapest, 1051, Hungary.

Email: vedresb@ceu.hu

STARK, David - Arthur Lehman Professor of Sociology, Department of Sociology; Director, Center on Organizational Innovation, Columbia University. Address: 116th Street and Broadway, New York, NY 10027, USA.

Email: dcs36@columbia.edu

\begin{abstract}
The authors seek to find a structural basis for the success of collectively executed projects. Here they continue to use previously elaborated concepts of structural folding and creative tension, but they go on to advance their approach by including the cognitive variables in the analysis instead of merely focusing on social structure. In this article, they examine the sociological factors that explain why some creative teams are able to produce game changers- cultural products that stand out as distinctive while also being critically recognized as outstanding. The authors build on work pointing to structural folding - the network property of a cohesive group whose membership overlaps with that of another cohesive group. They hypothesize that the effects of structural folding on game-changing success are especially strong when overlapping groups are cognitively distant. Measuring social distance separately from cognitive distance and distinctiveness independently from critical acclaim, the authors test their hypothesis about structural folding and cognitive diversity by analyzing team reassembly for 12422 video games and the career histories of 139727 video game developers. When combined with cognitive distance, structural folding channels and mobilizes a productive tension of rules, roles, and codes that promotes successful innovation. In addition to serving as pipes and prisms, network ties are also the source of tools and tensions.
\end{abstract}

Keywords: creativity; structural fold; creative tension; networks; cohesive group; cognitive diversity; innovations.

\section{Acknowledgements}

Research for this paper was supported by a grant from the National Science Foundation (SES-1123807). This is a fully coauthored paper. We are rotating the order of authors' names across a set of publications from our network analytic project. For their comments, criticisms, and suggestions, we are grateful to Shamus Khan, Gianluca Carnabuci, Matteo Prato, Elena Esposito, Koen Frenken, Monique Girard, Gernot Grabher, Michael Hutter, Francesco Mazzucchelli, Damon J. Phillips, and the participants of the CODES seminar at Columbia's Center on Organizational Innovation. Thanks to the European University Institute in Florence and to the Netherlands Institute for Advanced Study for supporting Stark during his leave year while this manuscript was in preparation.

\section{References}

Abbott A. (1999) Department and Discipline: Chicago Sociology at One Hundred, Chicago: University of Chicago Press. 
Agresti A., Finlay B. (2009) Statistical Methods for the Social Sciences: Upper Saddle River, N.J.: Pearson Prentice Hall.

Alexander J. C. (2004) Cultural Pragmatics: Social Performance between Ritual and Strategy. Sociological Theory, vol. 22, no 4, pp. 527-573.

Aoyama Y., Izushi H. (2003) Hardware Gimmick or Cultural Innovation? Technological, Cultural, and Social Foundations of the Japanese Video Game Industry. Research Policy, vol. 32, no 3, pp. 423-44.

Bauer D. F. (1972) Constructing Confidence Sets Using Rank Statistics. Journal of the American Statistical Association, vol. 67, pp. 687-690.

Becker H. S. (1974) Art as Collective Action. American Sociological Review, vol. 39, no 6, pp. 767-776.

Bellotti E. (2012) Getting Funded: Multi-Level Network of Physicists in Italy. Social Networks, vol. 34, no 2, pp. 215-229.

Berman S., Downs J., Hill C. (2002) Tacit Knowledge as a Source of Competitive Advantage in the National Basketball Association. Academy of Management Journal, vol. 45, no 1, pp. 13-31.

Bird A. (1994) Careers as Repositories of Knowledge: A New Perspective on Boundaryless Careers. Journal of Organizational Behavior, vol. 15, no 4, pp. 325-344.

Bissell T. (2011) Extra Lives: Why Video Games Matter. New York: Vintage Books.

Borgatti S., Cross R. (2003) A Relational View of Information Seeking and Learning in Social Networks. Management Science, vol. 49, no 4, pp. 432-445.

Bowker G. C., Star S. L. (2000) Sorting Things Out: Classification and Its Consequences. Cambridge, MA: MIT Press.

Brown J. S., Duguid P. (1991) Organizational Learning and Communities of-Practice: Toward a Unified View of Working, Learning, and Innovation. Organization Science, vol. 2, no 1, pp. 40-57.

Burt R. (1995) Structural Holes: The Social Structure of Competition, Cambridge, Mass.: Harvard University Press.

Burt R. (2004) Structural Holes and Good Ideas. American Journal of Sociology, vol. 110, no 2, pp. 349399.

Burt R. (2005) Brokerage and Closure: An Introduction to Social Capital, New York: Oxford University Press.

Burt R. (2014) Reinforced Structural Holes. Working paper. Booth School of Business, University of Chicago. August.

Carley K. M. (2001) Computational Approaches to Sociological Theorizing. Handbook of Sociological Theory (ed. J. H. Turner), New York: Kluwer Academic/Plenum Publishers, pp. 69-83. 
Carnabuci G., Bruggeman J. (2009) Knowledge Specialization, Knowledge Brokerage and the Uneven Growth of Technology Domains. Social Forces, vol. 88, no 2, pp. 607-641.

Caves R. (2002) Creative Industries: Contracts between Art and Commerce, Cambridge, Mass.: Harvard University Press.

Coleman J. (1988) Social Capital in the Creation of Human Capital. American Journal of Sociology, vol. 94, pp. S95-S120.

De Nooy W. (2003) Artistic Classifications as Collective Representations. Paper presented at the sixth conference of the European Sociological Association. Available at: http://www.uva.nl/binaries/content/documents/personalpages/n/o/w.denooy/en/tab-one/tab-one/cpitem $\% 5 \mathrm{~B} 98 \% 5 \mathrm{D} /$ asset (accessed 22 October 2013).

De Vaan M. (2014. Interfirm Networks in Periods of Technological Turbulence and Stability. Research Policy, vol. 43, no 10, pp. 1666-1680.

Delmestri G., Montanari F., Usai A. (2005) Reputation and Strength of Ties in Predicting Commercial Success and Artistic Merit of Independents in the Italian Feature Film Industry. Journal of Management Studies, vol. 42, no 5, pp. 975-1002.

DiMaggio P. (1997) Culture and Cognition. Annual Review of Sociology, vol. 23, pp. 263-287.

DiMaggio P. (2011) Cultural Networks. The SAGE Handbook of Social Network Analysis (eds. J. Scott, P. J. Carrington), Three Oaks, CA: SAGE Publications, pp. 286-300.

Eco U. (1990) Ilimiti dell'interpretazione [The Limits of Interpretation], Milan: Bompiani (in Italian).

Eco U. (2001) Introduction to Yuri Lotman. Universe of the Mind: A Semiotic Theory of Culture by Yuri Lotman, Bloomington: Indiana University Press, pp. vii-xiii.

Eliasoph N., Lichterman P. (2003) Culture in Interaction. American Journal of Sociology, vol. 108, no 4, pp. 735-794.

Evans J. (2010) Industry Induces Academic Science to Know Less about More. American Journal of Sociology, vol. 116, no 2, pp. 389-452.

Ganz M. (2000) Resources and Resourcefulness: Strategic Capacity in the Unionization of California Agriculture, 1959-1966. American Journal of Sociology, vol. 105, no 4, pp. 1003-1062.

Gartner. (2011) Market Trends: Gaming Ecosystem. June 10. Gartner, Inc. Available at: https://www.gartner. com/doc/1724014/market-trends-gaming-ecosystem- (accessed 22 October 2013).

Giuffre K. (2001) Mental Maps; Social Networks and the Language of Critical Reviews. Sociological Inquiry, vol. 71, no 3, pp. 381-93.

Gould G. (1994) Forgery and Imitation in the Creative Process. Grand Street, vol. 13, no 2, pp. 53-62. 
Grabher G. (2002) Cool Projects, Boring Institutions: Temporary Collaboration in Social Context. Regional Studies, vol. 36, no 3, pp. 205-214.

Grabher G. (2004) Learning in Projects, Remembering in Networks? Communality, Sociality, and Connectivity in Project Ecologies. European Urban and Regional Studies, vol. 11, no 2, pp. 103-23.

Grund T. U. (2012) Network Structure and Team Performance: The Case of English Premier League Soccer Teams. Social Networks, vol. 34, no 4, pp. 682-690.

Guimera R., Uzzi B., Spiro J., Amaral L. (2005) Team Assembly Mechanisms Determine Collaboration Network Structure and Team Performance. Science, vol. 308, no 5722, pp. 697-702.

Hargadon A., Bechky B. (2006) When Collections of Creatives Become Creative Collectives: A Field Study of Problem Solving at Work. Organization Science, vol. 17, no 4, pp. 484-500.

Heckman J.J. (1979) Sample Selection Bias as a Specification Error. Econometrica, vol. 47, no 1, pp. $153-$ 161.

Holland J. (1992) Complex Adaptive Systems. Daedalus, vol. 121, no 1, pp. 17-30.

Hutter M. (2011) Infinite Surprises: Value in the Creative Industries. The Worth of Goods: Valuation and Pricing in the Economy (eds. J. Beckert, P. Aspers), New York: Oxford University Press, pp. 201-220.

Ibert O., Schmidt S. (2012) Acting on Multiple Stages. Raumforschung und Raumordnung, vol.70, no 4, pp. 349-361.

Jacob F. (1977) Evolution and Tinkering. Science, vol. 196, no 4295, pp. 1161-1166.

Jaffe A. (1986) Technological Opportunity and Spillovers of R\&D: Evidence from Firms' Patents, Profits, and Market Value. American Economic Review, vol. 76, no 5, pp. 984-1001.

Jerolmack C., Khan S. (2014) Talk Is Cheap: Ethnography and the Attitudinal Fallacy. Sociological Methods and Research, vol. 43, no 2, pp. 178-209.

Lamont M. (1992) The Dignity of Working Men, Cambridge, MA: Harvard University Press.

Lampel J., Lant T., Shamsie J. (2000) Balancing Act: Learning from Organizing Practices in Cultural Industries. Organization Science, vol. 11, no 3, pp. 263-269.

Lester R., Piore M. (2004) Innovation: The Missing Dimension, Cambridge, MA: Harvard University Press.

Lingo E., O’Mahony S. (2010) Nexus Work: Brokerage on Creative Projects. Administrative Science Quarterly, vol. 55, no 1, pp. 47-81.

Lopes P. D. (1992) Innovation and Diversity in the Popular Music Industry, 1969 to 1990. American Sociological Review, vol. 57, pp. 56-71.

Lotman Y. (1990) Universe of the Mind: A Semiotic Theory of Culture, Bloomington: Indiana University Press. 
Lotman Y. (2009) Culture and Explosion, Berlin: De Gruyter Mouton.

Mizruchi M. (1996) What Do Interlocks Do? An Analysis, Critique, and Assessment of Research on Interlocking Directorates. Annual Review of Sociology, vol. 22, pp. 271-298.

Mohr J. W. (1994) Soldiers, Mothers, Tramps, and Others: Discourse Roles in the 1907 New York City Charity Directory. Poetics, no 22, pp. 327-357.

Obstfeld D. (2005) Social Networks, the Tertius Iungens Orientation, and Involvement in Innovation. Administrative Science Quarterly, vol. 50, no 1, pp. 100-130.

Owen-Smith J., Powell W. W. (2004) Knowledge Networks as Channels and Conduits: The Effects of Formal Structure in the Boston Biotechnology Community. Organization Science, vol. 15, no 1, pp. 5-21.

Pachucki M. A., Breiger R. L. (2010) Cultural Holes: Beyond Relationality in Social Networks and Culture. Annual Review of Sociology, no 36, pp. 205-224.

Peterson R. A., Berger D. G. (1971) Entrepreneurship in Organizations: Evidence from the Popular Music Industry. Administrative Science Quarterly, vol. 16, no 1, pp. 97-106.

Podolny J. M. (2001) Networks as the Pipes and Prisms of the Market. American Journal of Sociology, vol. 107, pp. 33-60.

Poincaré H. (1985[1908]) Papers on Fuchsian Functions. Springer-Verlag: Berlin.

Portes A., Sensenbrenner J. (1993) Embeddedness and Immigration: Notes on the Social Determinants of Economic Action. American Journal of Sociology, vol. 98, no 6, pp. 1320-1350.

Reagans R., McEvily B. (2003) Network Structure and Knowledge Transfer: The Effects of Cohesion and Range. Administrative Science Quarterly, vol. 48, no 2, pp. 240-267.

Rowlinson M., Booth C., Clark P., Delahaye A., Procter S. (2010) Social Remembering and Organizational Memory. Organization Studies, vol. 31, no 1, pp. 69-87.

Ruef M., Aldrich H., Carter N. (2003) The Structure of Founding Teams: Homophily, Strong Ties, and Isolation among U.S. Entrepreneurs. American Sociological Review, vol. 68, no 2, pp. 195-222.

Sartori A. (2003) An Estimator for Some Binary-Outcome Selection Models Without Exclusion Restrictions. Political Analysis, no 11, pp. 111-138.

Schumpeter J. (2012) Capitalism, Socialism and Democracy, London: Routledge.

Sewell W. F. (1992) A Theory of Structure: Duality, Agency, and Transformation. American Journal of Sociology, vol. 98, no 1, pp. 1-29.

Simmel G. (1955 [1922]) Conflict and the Web of Group Affiliations (trans., ed. K. Wolff), Glencoe, Ill.: Free Press.

Sohn M.-W. (2001) Distance and Cosine Measures of Niche Overlap. Social Networks, vol. 23, no 2, pp. 141165. 
Stark D. (2009) The Sense of Dissonance: Accounts of Worth in Economic Life, Princeton, N.J.: Princeton University Press.

Swidler A. (2008) Comment on 'Socrates, Skinner, and Aristotle: Three Ways of Thinking About Culture in Action’ by Stephen Vaisey. Sociological Forum, vol. 23, no 3, pp. 614-618.

Swidler A. (2008) Comment on 'Socrates, Skinner, and Aristotle: Three Ways of Thinking About Culture in Action’ by Stephen Vaisey. Sociological Forum, vol. 23, no 3, pp. 614-618.

Tschang T. (2007) Balancing the Tensions between Rationalization and Creativity in the Video Games Industry. Organization Science, vol. 18, no 6, pp. 989-1005.

Uzzi B., Spiro J. (2005) Collaboration and Creativity: The Small World Problem. American Journal of Sociology, vol. 111, no 2, pp. 447-504.

Vedres B., Stark D. (2010) Structural Folds: Generative Disruption in Overlapping Groups. American Journal of Sociology, vol. 115, no 4, pp. 1150-1190.

Wegner D. M. (1995) A Computer Network Model of Human Transactive Memory. Social Cognition, no 13, pp. 1-21.

Weitzman M. (1998) Recombinant Growth. Quarterly Journal of Economics, vol. 113, no 2, pp. 331-360.

Williamson O. E. 1981. The Economics of Organization: The Transaction Cost Approach. American Journal of Sociology, vol. 87, no 3, pp. 548-577.

Wuthnow R. (1987) Meaning and Moral Order: Explorations in Cultural Analysis, Berkeley and Los Angeles: University of California Press.

Zerubavel E. (1997) Social Mindscapes: An Invitation to Cognitive Sociology, Cambridge, Mass.: Harvard University Press.

Zuckerman E. (1999) The Categorical Imperative: Securities Analysts and the Illegitimacy Discount. American Journal of Sociology, vol. 104, no 5, pp. 1398-1438.

Received: September 21, 2015.

Citation: De Vaan M., Vedres B., Stark D. (2016) Igry-sobytiya: topologiya kreativnosti [Game Changer: The Topology of Creativity], Journal of Economic Sociology = Ekonomicheskaya sotsiologiya, vol. 17, no 4, pp. 53-90. Available at: https://ecsoc.hse.ru/2016-17-4.html (in Russian). 


\section{РАСШИРЕНИЕ ГРАНИЦ}

\section{С. Боулз}

\section{Моральная экономика: почему хорошие стимулы не заменят хороших граждан}

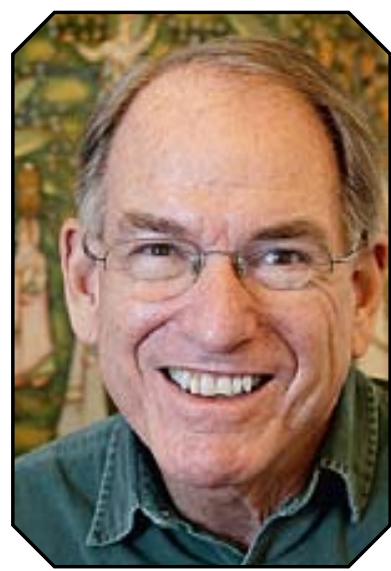

БОУЛ3 Самуэль профессор, руководитель Программы в области поведенческих наук Института Санта-Фе. Адрес: США, 87501, шт. Нью-Мексико, г. Санта-Фе, ул. ГайдПарк-роуд, д. 1399.

Email: bowles@santafe. edu

Перевод с английского Даниила Шестакова

Публикуется с разрешения Издательства Института им. Е. Т. Гайдара.
Представляемая книга «The Moral Econоту» («Моральная экономика») отчасти опирается на материаль Кастловских лекиий, прочитанных Самуэлем Боулзом в Йельском университете, и является результатом 30-летней работы автора над вопросами культурных эффектов рынков и стимулов. В книге Боулз предлагает новую политическую парадигму, отличительная черта которой - отказ от модели Ното есопотісия в пользу подхода $\kappa$ «людям как они есть». Такой подход, по мнению автора, делает возможным синергию между стимулами и ограничениями, с одной стороны, и этическими и альтруистическими мотивами реальных людей - с другой. Автор уверен в том, что только те рыночные экономики, которые не отвергают своей культурной основы и людских добродетелей, способны работать хорошо.

Журнал «Экономическая сочиология» публикует первую главу книги «The Problem with Homo economicus» («Проблема с Ното есопотісиs»), — 8 которой автор пытается убедить читателей, что экономическая модель человека не годится в качестве ориентира при разработке политического курса или организации бизнеса. Согласно Боулзу, на то есть две причины: во-первых, материальные стимулы не являются гарантией хорошего управления, а во-вторых, политика, которая опирается на модель эгоистичного и аморального человека, создаёт условия для его господства в реальности. В выстраивании аргументащии автор обращается к широкому кругу философской, политической и экономической литературы. При этом книга легко читается благодаря увлекательным историям и жизненным примерам.

Ключевые слова: моральная экономика; экономический человек; инструментальные мотивы; нравственные чувства; мошенничество; рынки.

\section{I. Проблема c Homo economicus}

Два с половиной столетия назад Жан-Жак Руссо предложил читателям своей книги «Об общественном договоре» рассмотреть «людей такими, каковы они, а законы - такими, какими они могут быть» [Rousseau 1984] (рус. пер. цит. по: [Руссо 1969: 151]). Предложение не потеряло актуальности. Мы знаем, что хорошее управление невозможно без понимания того, как люди отреагируют на законы, экономические стимулы, информацию или моральные призывы, которые составляют систему управления. И реакция зависит от желаний, целей, привычек, убеждений и моральных качеств, которые определяют и ограничивают действия людей.

Но что значит понять «людей такими, каковы они», как писал Руссо? 
Источник: Боулз С. (готовится к изданию) Моральная экономика: почему хорочие стимульи не заменят хороших граждан. М.: Изд-во Института Гайдара. Пер. с англ.: Bowles S. 2016. The Moral Economy. Why Good Incentives Are No Substitute for Good Citizens. New Heaven; London: Yale University Press.
Возникает экономический человек - Hoто economicus. Среди экономистов, юристов и политиков, на которых идеи экономистов и юристов произвели впечатление, распространено представление о том, что, рассуждая о дизайне политического курса или системы законов, как если бы мы рассуждали об организации фирм или других частных организаций, необходимо предполагать, что люди - граждане, наёмные работники, партнёры по бизнесу, потенциальные преступники - преследуют лишь собственный интерес и являются аморальными. Отчасти по этой причине материальные стимулы используются теперь для мотивации студентов к учёбе, учителей - к тому, чтобы они лучше учили, для сбрасывания лишнего веса и попыток бросить курить, призывов голосовать на выборах и перейти от пластиковых пакетов к многоразовым сумкам, для формирования доверительной ответственности в финансовом менеджменте и фундаментальных исследованиях. Bсе эти виды деятельности, в отсутствие экономических стимулов, могут мотивироваться внутренними, этическими или прочими неэкономическими причинами.

Если учесть популярность в кругах законодателей, экономистов и политиков утверждения об аморальности людей и преследовании ими собственного интереса, может показаться странным, что в это утверждение никто на самом деле не верит. В действительности, его принимают из соображений благоразумия, а не реализма. Даже Юм (см. конец эпиграфа ${ }^{1}$ к этой книге) предупреждает читателя, что утверждение ложно.

Я надеюсь убедить вас в том, что при разработке законов, выборе политического курса или создании деловой организации выбирать Homo economicus в качестве своей модели для поведения гражданина, наёмного работника, студента или заёмщика едва ли разумно по двум причинам. Во-первых, политический курс, который следует из этой парадигмы, сам по себе приближает ситуацию всеобщей аморальной эгоистичности к истине: люди часто принимают свои интересы в расчёт сильнее, когда материальные стимулы присутствуют, по сравнению с ситуацией, когда материальные стимулы отсутствуют. Во-вторых, штрафы, награды и прочие материальные стимулы не всегда хорошо работают. Сколь бы хорошо эти стимулы ни усмиряли алчность мошенников (как выразился Юм), одни стимулы не могут заложить основу для хорошего управления.

Если я прав, тогда размывание этических и прочих социальных мотиваций, жизненно важных для хорошего управления, может быть непредсказуемым культурным последствием политик, предпочитаемых экономистами, в том числе более детальных и лучше определённых прав собственности, продви-

\footnotetext{
Книге предпослан эпиграф: «Политические писатели установили ту максиму, что при рассмотрении любой системы правительства <..> каждый человек должен предполагаться мошенником, то есть во всех своих действиях не имеющим иного интереса, кроме частного. Согласно этому интересу мы должны управлять им и посредством сего делать его, независимо от его неутолимой алчности и амбиций, союзником в достижении общей пользы < .. > Это, следовательно, лишь политическая максима, что каждого человека следует полагать мошенником; в то же время достаточно странно, что максима должна быть верна в политике, хотя является ложной как факт» (Дэвид Юм. Опыты нравственные, политические и литературные. 1742). - Примеч. ред.
} 
жения рыночной конкуренции, большего использования денежных стимулов для изменения поведения людей.

Я покажу, что эти и другие политические меры, рекламируемые как необходимые для функционирования рыночной экономики, могут также развивать в людях собственный интерес и подрывать те средства, с помощью которых общество поддерживает устойчивую гражданскую культуру кооперирующихся и щедрых граждан. Эти политические меры могут даже подрывать социальные нормы, жизненно необходимые для работы самих рынков. Среди культурных жертв подобного процесса вытеснения оказываются такие ежедневные добродетели, как правдивое раскрытие своих активов и обязательств при получении займа, готовность держать слово и усердно работать даже тогда, когда никто не наблюдает. Рынки и прочие экономические институты не работают хорошо там, где эти и другие нормы отсутствуют или подорваны. Больше, чем когда-либо, высокопроизводительная экономика знаний требует культурной основы в виде этих и других социальных норм. Среди них уверенность в том, что рукопожатие является рукопожатием; когда в этом есть сомнения, взаимное недоверие приведёт к потере выгод для всех сторон сделки.

Парадоксальная идея о том, что политические меры, которые экономисты считают «улучшением» рынков, способны ухудшать работу рынков, справедлива не только для рынков. Гражданские добродетели людей и их внутреннее желание придерживаться социальных норм могут быть растрачены в результате таких политических мер, и, вполне вероятно, растрачены безвозвратно, а в будущем пространство для лучших политических мер окажется гораздо более узким. Хотя некоторые экономисты представляют себе, как в далёком прошлом Ното есопотісиs изобрёл рынки, в реальности всё могло быть совсем наоборот: преследование аморального собственного интереса может быть следствием жизни в том обществе, которое идеализируют экономисты.

Проблема, с которой сталкивается политик или законодатель, выглядит следующим образом: стимулы и ограничения необходимы в любой системе управления. Но когда система строится в предположении о том, что «люди как они есть» похожи на Homo economicus, стимулы могут привести к обратному результату, заставив людей преследовать собственный интерес, который эти стимулы изначально и пытались сдержать для общего блага. Проблемы не было бы, будь Homo economicus хорошим описанием «людей как они есть». В этом случае нечего было бы вытеснять. Но в последние два десятилетия поведенческие эксперименты (как мы увидим в главах III, IV и $\mathrm{V}^{2}$ ) дали серьёзные основания в пользу того, что этические и альтруистические мотивы распространены во всех человеческих обществах. Эксперименты показывают, что эти мотивы иногда вытесняются политическими мерами и стимулами, которые апеллируют к материальному интересу. Вот один пример.

В Хайфе, в детском саду, ввели штраф для тех родителей, которые забирали своих детей очень поздно. Это не сработало: после введения штрафа доля опаздывающих родителей удвоилась [Gneezy, Rustichini 2000]. Через 12 недель штраф отменили, но доля опаздывающих родителей не снизилась до прежней. (Их опоздания по сравнению с контрольной группой, в которой штраф не вводился, показаны на рис. 1.)

Введение штрафов привело к результату, противоположному ожидаемому, что заставляет нас предположить наличие некоей негативной синергии между экономическими стимулами и моральным поведением. Введение цены за опоздание, как если бы опоздания продавались, подорвало этические обязательства родителей не возлагать излишних хлопот на учителей и заставило родителей думать, что опоздания - это ещё один товар, который они могут купить.

2 Глава III «Нравственные чувства и материальные интересы», глава IV «Стимулы как информация» и глава V «Либеральная гражданская культура». - Примеч. ред. 


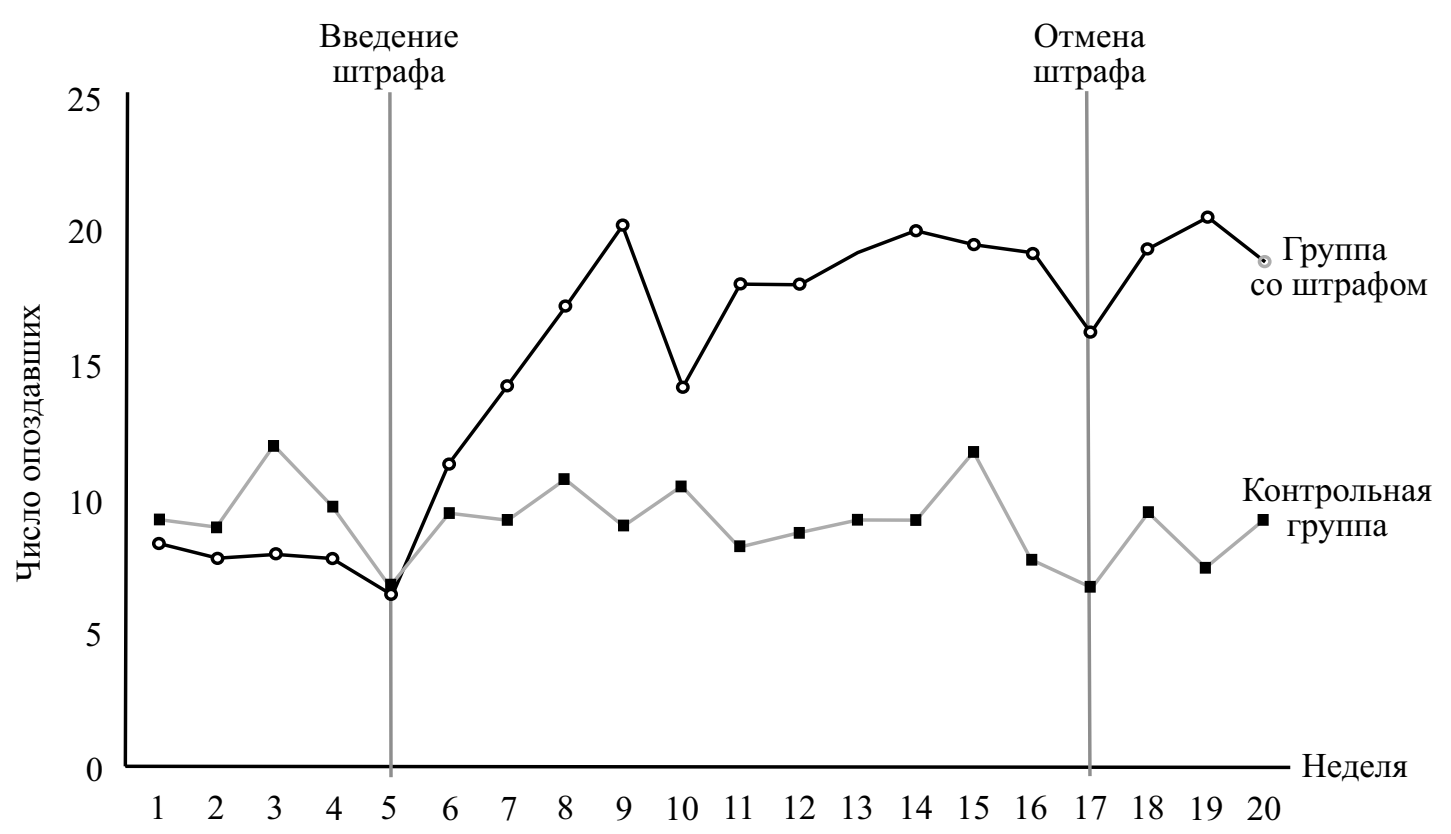

Источник: [Gneezy, Rustichini 2000: 804].

Рис. 1. Эффект штрафа на опоздания в детском саду Хайфы

Я не сомневаюсь, если бы штраф был достаточно велик, родители отреагировали бы иначе. Но введение цены на всё, что только можно, не слишком удачная идея, даже если она реализуема и правильные цены удалось бы найти (и мы увидим, что всё это очень большое ЕСЛИ).

Можно показать детям деньги или обсудить с ними монеты (а не другие, неденежные объекты), как было сделано в недавнем эксперименте, и тогда дети будут вести себя менее просоциально и меньше помогать окружающим в их повседневных делах [Gasiorowska, Zaleskiewicz, Wygrab 2012].

Ещё в одном проведённом исследовании дети младше двух лет охотно и без какой-либо награды помогали взрослому достать брошенный далеко предмет. Но после того, как за помощь взрослому их наградили игрушкой, доля помогающих детей снизилась на 40\%. Феликс Варнекен и Майкл Томаселло, авторы исследования, делают вывод: «Дети обладают естественной склонностью помогать, но внешние награды могут подорвать эту склонность, поэтому практики социализации должны основываться на таких тенденциях и работать в союзе, а не в конфликте с природной склонностью детей действовать альтруистично» [Warneken, Tomasello 2008: 1787].

Этот совет может пригодиться не только родителям, но и политикам.

Как политики должны реагировать на тот факт, что, хотя экономические стимулы и этические и альтруистические мотивы необходимы для эффективной политики, первые уменьшают значимость вторых? Если учитывать оба источника мотивации, политикам стоит возлагать более скромную роль на экономические стимулы при проведении политического курса. Если стимулы подрывают социальные ценности, но и то, и другое нужно, тогда стоит использовать меньше стимулов и учитывать эффект вытеснения.

Похожие рассуждения могут заставить политиков ограничить роль рынков в распределении ресурсов и предпочесть большую роль государства или неформальных нерыночных организаций. Похожее решение предлагает Майкл Сандел в книге «What Money Can’t Buy: The Moral Limits of Markets» («Чего 
не купишь за деньги: моральные границы рынков»): «Назначение цены на любую деятельность человека подрывает некоторые очень важные моральные и гражданские блага» [Sandel 2012: 121]. Сандел убедительно призывает к общественной дискуссии о том, где рынки служат общему благу, а где они не нужны. Дебра Зац указывает на политические причины для этого в книге «Why Some Things Should Not Be for Sale...» («Почему не всё нужно выставлять на продажу...») и утверждает, что ограничение некоторых рынков является необходимым для достижения политического равенства и фундаментальным для демократической культуры и политической системы [Satz 2010]. Меня меньше волнует распространение рынков (по сравнению с государством и другими способами распределения), и больше - проблематичное использование экономических стимулов на рынке, в рамках фирмы или при осуществлении государственной политики. Факты, свидетельствующие о том, как стимулы способны вытеснять этические и альтруистические мотивы, дополняют рассуждения Сандела и Зац.

Но важно понимать, что нельзя винить во всём стимулы сами по себе. Вытеснение может отражать фундаментальную проблему, вытекающую из природы отношений между тем, кто создаёт стимул, и целью этого стимула. Например, стимулы, встроенные в оплату труда и контроль на рабочем месте, могут сообщать работнику, что его работодатель - жадный и дотошный или не доверяет работнику. Также стимулы способны неявно сообщать неправильную информацию (как это было в Хайфе): «В опозданиях нет ничего плохого, пока вы за них платите».

В таком случае политики могут сделать больше, чем просто ограничить роль стимулов и рынков. Они могут перевернуть вытеснение с ног на голову. В новой политической парадигме, основанной на таких рассуждениях, традиционные политические инструменты - стимулы и наказания - способны усиливать, а не подрывать этические и альтруистические мотивы людей, что, в свою очередь, увеличит эффективность законодательных ограничений и материальных стимулов. Идея о том, что законы и мораль могут работать в синергии, высказывалась ещё два тысячелетия назад. «Коль преступлению вослед / Не угрожает казнь, к чему все наши стоны, / И там, где нравственности нет, / Что пользы принесут напрасные законы!» [Нorace 2004: 199] ${ }^{3}$. Для Горация нравственность и законы должны в хорошем обществе работать вместе.

Мне хотелось бы предложить здесь политическую парадигму синергии между стимулами и ограничениями, с одной стороны, и этическими и альтруистическими мотивами - с другой. Основы подобной парадигмы были заложены ещё до Горация - жителями Древних Афин. В последней главе ${ }^{4}$ я объясню, как в Хайфе всё могло бы пойти совсем по-другому, если бы там последовали примеру Афин.

Новая политическая парадигма будет основана и на новом, обоснованном с эмпирической точки зрения, подходе к «людям как они есть». Начать стоит с поиска замены для Homo economicus. Важно, что новая парадигма будет включать новые свидетельства о когнитивных процессах, которые обусловливают принимаемые нами решения. Работы Дэниэла Канемана, Ричарда Талера, Касса Санстина, Амоса Тверски и многих других показали, что люди вовсе не настолько дальновидны, расчётливы и последовательны в своих решениях, как это обычно предполагают экономисты [Kahneman 1994; Kahneman, Tversky 2000; Thaler, Sunstein 2008]. На самом деле, мы все склоняемся к статус-кво и непоследовательны в выборе альтернатив, которые отдалены от нас на различные расстояния в будущее.

Даже если нам объяснят, как избежать этих «сдвигов», мы будем совершать ошибки, которые экономисты называют вычислительными. Например, принимая решение в ситуации неопределённости, люди рассматривают положительную вероятность события независимо от её величины совсем иначе,

3 Перевод А. А. Фета. Цит. по: http://horatius.ru/index.xps?3.324 - Примеч. ред.

4 Глава VII «Мандат для аристотелевского законодателя». - Примеч. ред. 
чем знание о том, что событие точно не произойдёт. Канеман, заслуживший Нобелевскую премию по экономике психолог, утверждает: «Люди близоруки в своих решениях, обладают низкой способностью в предсказании собственных вкусов в будущем и могут совершать ошибки из-за ненадёжной памяти и неверной оценки прошлого опыта» [Kahneman 1994].

Экономисты, которые ставят совершение выбора в центр всей человеческой деятельности, внезапно открывают для себя тот факт, что люди не слишком хорошо это делают.

Талер, Санстин, Канеман и другие сделали соответствующие выводы для публичной политики из новых данных о когнитивных процессах. Отчасти по этой причине на страницах этой книги меня в меньшей степени будет волновать, как мы принимаем решения, и в большей - что мы оцениваем, когда принимаем решения, как стимулы и прочие аспекты публичной политики могут изменять наши оценки, и как, зная всё это, мы должны проводить политику.

Я начну с объяснения того, что представляет собой политическая парадигма, основанная на предпосылке Homo economicus, и перескажу странную историю о том, как политические меры, следующие из этой парадигмы, могут вытеснять этические и прочие социальные мотивы, но сторонникам парадигмы Homo economicus этот факт оказался либо неизвестен, либо неважен.

\section{II. Конституция для мошенников}

Заметив подозрительное увеличение больничных, которые пожарные брали по понедельникам и пятницам, брандмайор пожарного департамента Бостона с 1 декабря 2001 г. отменил политику департамента, который оплачивал неограниченное количество больничных. В своём департаменте он ввёл норму: максимум 15 оплачиваемых отгулов по болезни; пожарным, которые превысят этот максимум, сокращалась зарплата. Вот как на это откликнулись пожарные: число больничных, взятых в Рождество и на Новый год, увеличилось в 10 раз по сравнению с прошлым годом.

Брандмайор ответил на это отменой праздничной премии [Belkin 2002]. Пожарных это не остановило: в следующем году они взяли 13431 больничный день по сравнению с 6432 днями годом ранее [Greenberger 2003]. Многие, явно оскорблённые новой системой, стали тестировать её на прочность и отбросили этику, предполагавшую служение обществу в любых обстоятельствах, даже когда сами болели.

Должен признаться, что могу понять брандмайора. Однажды я предложил своим детям прайс-лист за помощь по дому, что дало бы им немного больше карманных денег. В ответ дети попросту перестали делать ту работу по дому, которую они раньше и так более-менее делали без всяких стимулов.

Трудности брандмайора, как и мой провалившийся эксперимент, не исключение. Очевидно, что использование явных экономических стимулов и ограничений для того, чтобы заставить людей действовать социально ответственным образом, иногда неэффективны или даже, как показывает пример бостонского брандмайора, контрпродуктивны. Но проблема ли это? Убеждён, что больший штраф помог бы решить проблему. То, что пожарные берут много больничных в Рождество и Новый год, не означает, что деньги их не интересуют. Если бы брандмайор выбрал больший штраф, пожарные почти наверняка отреагировали бы так, как нужно, даже если бы при этом злость и недоверие возобладали над чувством долга. Экономический интерес заместил бы гордость служения обществу.

Но эти ограничения и стимулы имеют свои пределы. Большие штрафы и драконовские наказания сдержали бы наплыв фальшивых больничных, но смогли ли они мотивировать пожарных на неочевидные и 
трудноизмеримые действия, связанные с профессионализмом и мужеством, необходимыми в их работе? Даже если бы такого удалось добиться запредельными штрафами, либеральное общество едва ли одобрило бы такой подход. Вместо того чтобы пытаться вытеснить штрафами чувство долга пожарного, брандмайору стоило бы поискать такие меры, которые укрепили бы гражданскую позицию.

Отношение к реакции пожарных на стимулы брандмайора определяет и позицию в некотором древнем и неразрешенном споре в философии управления. Суть спора состоит, грубо говоря, в следующем: может ли работать конституция для мошенников, и, если может, будет ли хорошей идеей для всех нас жить в соответствии с такой конституцией? Я начну отвечать на эти вопросы с того, что расскажу замечательную историю о том, как идея конституции для мошенников возникла, а затем приобрела неожиданный оборот в работах экономистов, превративших рынок в зону без морали, оказавшуюся вне действия этических суждений, которыми мы обычно руководствуемся в рамках семьи, района или государства ${ }^{5}$.

\section{Инновация Макиавелли}

Политические философы от Аристотеля до Фомы Аквинского, Жан-Жака Руссо и Эдмунда Бёрка рассматривали культивирование гражданской добродетели не просто как один из признаков хорошего правительства, но как его необходимую основу. «[З]аконодатели, приучая [к законам] граждан, делают их добродетельными, - писал Аристотель в “Этике”, - и в этом отличие одного государственного устройства от другого, а именно добродетельного от дурного» [Aristotle 1962: 103] (рус. пер. цит. по: [Аристотель 1983: 79]). Веком раньше Конфуций давал советы о том, как такого результата можно достичь, и о тех ловушках, которых следует избегать: «Если править с помощью закона, улаживать наказывая, то народ остережётся, но не будет знать стыда. Если править на основе добродетели, улаживать по ритуалу, народ не только устыдится, но и выразит покорность» [Confucius 2007: 20] (рус. пер. цит. по: [Конфуций 2000: 10]).

Однако из XXI века отсылки к добродетели и стыду как основе хорошего общества кажутся странными, если не губительными. Рынок был воспет Фридрихом Хайеком как «социальная система, функционирование которой не требует <..> чтобы все люди стали лучше, чем они есть теперь, но которая использует людей во всём их разнообразии и сложности: иногда хорошими, иногда дурными» [Hayek 1948: 12] (рус. пер. цит. по: [Хайек 2011: 23]). После краха в 1987 г. биржи газета «New York Times» опубликовала статью «Ban Greed? No: Horness It» («Запретить алчность? Нет: усмирить её»). В статье говорилось: «Возможно, самой важной является идея о том, чтобы отличать мотив от последствия. Производные финансовые инструменты привлекают алчных так же, как сырое мясо привлекает пираний. Ну и что? Личная алчность может приводить к общественному благу. Разумная цель для регулирования ценных бумаг заключается в том, чтобы направить алчность в правильное русло, а не подавлять её» [New York Times 1988]. Нобелевский лауреат Джеймс Бьюкенен показывал, как это может работать, на примере своего визита в лавку фруктов рядом со своим домом в Блэксбурге, Виргиния. «Я не знаю продавца фруктов лично, и меня не особенно интересует уровень его благосостояния. Он точно так же относится и ко мне. Я не знаю, да мне и не надо знать, каково его положение: ужасающая бедность, большое богатство или нечто среднее между ними. Точно так же и ему абсолютно ничего не известно о моём материальном положении. Однако мы оба можем быстро совершить обмен $<\ldots>$ поскольку обе стороны согласны с правами собственности, которыми они обладают» [Buchanan 1975: 71] (рус. пер. цит. по: [Бьюкенен 1997: гл. 2]).

В подобном способе мышления юристы не отстают от экономистов. «Если хотите изучить право, и ничего кроме права, — объяснял своим студентам в 1897 г. Оливер Уэнделл Холмс-младший (и каждому

5 Похожие истории (но немного под другим углом) были замечательно раскрыты в следующих работах: [Dumont 1977; Hirschman 977]. - Примеч. автора. 
поступающему на юридический факультет с тех пор говорили то же самое), — вы должны смотреть на него с точки зрения плохого человека, который смотрит лишь на то, как имеющееся у него знание поможет ему улучшить собственное материальное положение, а не с точки зрения хорошего человека, который ищет мотивы для своих действий в рамках закона или в более смутных рамках собственной совести $<\ldots>$ Обязанность выполнить контракт в обычном праве означает предсказание того, что вы заплатите ущерб в ситуации, если не выполните контракт, — и ничего больше» [Holmes 1897]. Хайек приписывал похожий, но чуть более детально изложенный анализ Адаму Смиту: «[П]очти не вызывает сомнений, что Смита главным образом интересовало не столько то, чего человек мог бы время от времени достигать, когда он бывает на высоте, сколько то, чтобы у него было как можно меньше возможностей наносить вред, когда он оказывается несостоятелен» [Hayek 1948: 11] (рус. пер. цит. по: [Хайек 2011: 23]).

Долгая дорога от аристотелева законодателя, который культивирует хорошие привычки у граждан, до системы экономического управления и закона для «плохих людей» началась в XVI веке с Никколо Макиавелли. Как и Аристотеля, Макиавелли интересовали социальные установления, которые удержали бы то, что он называл «разложением», но его совет был иным, и он предвосхищает афоризм Юма про мошенников (эпиграф к этой книге) более чем на два столетия: «[О]снователю республики, сочиняющему для неё законы, необходимо исходить из присущих людям дурных наклонностей <...> Говорят ведь, что голод и бедность побуждают людей к выдумке и изворотливости, а законы склоняют их к добру» [Machiavelli 1984: 69-70] (рус. пер. цит. по: [Макиавелли 2004: 148-149]). Макиавеллиевское «законы склоняют их к добру» может звучать похоже на аристотелевское «воспитание добродетели» в общественности. Но здесь, как и в выражении «все люди дурны», Макиавелли использует слово «добро» (buoni) и «дурны» (rei) для описания действий, а не черт характера.

Политический философ Лео Штраусс ведёт происхождение подобного мышления среди экономистов XX столетия от жившего в XVI веке флорентийца из прошлого абзаца: «Экономизм - это вызревший макиавеллизм» [Strauss 1988: 49]. Истоки того, что Штраусс назвал «экономизмом», и в самом деле можно найти в сочинениях Макиавелли, который, как и Аристотель, но не как современные экономисты, не считал возможным, что хорошее управление возможно над эгоистичными («испорченными») гражданами: «[Н]е существует законов и предписаний, способных остановить всеобщее разложение. Ведь, чтобы сохранить добрые нравы, необходимы законы, а для соблюдения законов нужны добрые нравы» [Machiavelli 1984: 109] (рус. пер. цит. по: [Макиавелли 2004: 185]).

Для Макиавелли законы выполняют две функции: создают стимулы и ограничения для сдерживания собственного интереса к общественной пользе и в то же время поддерживают добрые нравы, от которых зависит эффективность законов: «[Д]обрые примеры [добродетели, virtì] проистекают из хорошего воспитания, правильное воспитание - из хороших законов» [Machiavelli 1984: 71] (рус. пер. цит. по: [Макиавелли 2004: 150]). Макиавелли поэтому принимал синергетическую парадигму, которую я опишу в заключительных главах этой книги, подразумевающую, что хорошие законы и хорошие обычаи являются комплементами, а не субститутами.

Тем не менее для Макиавелли задачей правительства является преимущественно побуждение граждан, руководствующихся «естественными и обычными нравами», действовать так, как если бы они были хорошими. Для Макиавелли ясно, и особенно это заметно в «Рассуждении на первую декаду Тита Ливия», что не мораль граждан является условием того, что республика хорошо управляется, но, скорее, способность государя «сочинять для неё законы» (цит. по: [Benner 2009]). По сравнению с Италией, пишет Макиавелли, Испания и Франция управляются хорошо, но это различие определяется «не столько добропорядочностью народов, которой чаще всего и в помине нет <...», сколько существующими в этих королевствах порядками. «Франция, - продолжает он, - подчиняется законам больше 
всех известных в наше время монархий» [Machiavelli 1984: 174, 180] (рус. пер. цит. по: [Макиавелли 2004: 248]).

Вывод очевиден: гражданами с их обычными склонностями и желаниями можно тем не менее управлять, если их поведение «смягчается < ..> законами». Новой здесь является идея о том, что качество управления в обществе не есть просто сумма характеристик членов общества. Хорошее управление функция не столько от того, насколько хороши составляющее общество граждане, сколько от того, насколько хорошо социальные институты организуют взаимодействие между гражданами.

Современные физики могли бы, перефразировав Макиавелли, сказать, что качество управления является эмерджентным свойством политики, то есть свойством общества, которое не может быть полностью прямо выведено из характеристик граждан, его составляющих. Для Макиавелли хорошее управление, следовательно, является эмерджентным свойством хорошо упорядоченного общества.

Два столетия спустя радикальная версия этой идеи станет ключевым выводом скандальной «Басни о пчёлах» Бернарда де Мандевиля. В этой книге эксцентричный голландский врач, переехавший в Лондон, утверждал, что для поддержания общественного порядка добродетель не просто необязательна, но даже вредна. Улей Мандевиля процветал благодаря разнузданной алчности и гнусной конкуренции. Но когда пчёлы стали добродетельными, наступила разруха. (Мандевиль не мог знать, что медоносные пчёлы (род Aріs) наиболее из всех видов склонны к сотрудничеству и генетически не приспособлены к конкуренции.) Вывод Мандевиля состоял в том, что снижение спроса на товары как результат добродетельной бережливости стало источником экономического коллапса; считается, что этот вывод предвосхищает парадокс сбережений, лежащий в основе кейнсианской экономики. В подзаголовке к изданию «Басни о пчёлах» 1714 г. анонсировалось, что книга содержит «некоторые рассуждения, показывающие, как человеческие пороки < ..> могут приводить к пользе гражданского общества и могут приводить к моральной добродетели», и, как писал Мандевиль, «в итоге славным пчёлам зло благополучие несло» [Mandeville 1924: 24] (рус. пер. цит. по: [Субботин 1986: 123]).

Для тех читателей, которые оказались неспособны расшифровать урок «Басни...», Мандевиль написал комментарий в прозе: «Голод, жажда и нагота - первые тираны, которые заставляют нас действовать; за ними следуют наши великие патроны, покровительствующие развитию всех искусств и наук, ремесел, профессий и занятий, - гордость, лень, чувственность и непостоянство, в то время как великие надсмотрщики - нужда, скупость, зависть и честолюбие < .. > принуждают членов общества $<\ldots>$ подчиняться тяжести и нудности их положения; короли и принцы не являются исключением» [Mandeville 1988a: 366] (рус. пер. цит. по: [Мандевиль 1974: 327]). Для Мандевиля положительные следствия того, что Макиавелли назвал «обычными нравами», не являются естественным фактом человеческого общества. Подобно Макиавелли, видевшему основание хорошего правления в человеческой способности подчиняться законам, для Мандевиля оно лежало в «умелом управлении со стороны искусного политика», которое позволяло превратить «пороки отдельных лиц» в «блага для общества» [Mandeville 1988a: 369] (рус. пер. цит. по: [Мандевиль 1974: 330]).

По контрасту с аристотелевым взглядом на то, как хорошие законы создают хороших граждан, «Басня...» Мандевиля предполагала, что правильные институты могут сдержать низкие мотивы и достичь высоких целей. Адаму Смиту оставалось объяснить, как именно свершится эта невероятная алхимия, и объяснение это находится в его знаменитом описании бизнесмена, потребителя, фермера: «[О]н преследует лишь свою собственную выгоду, причём в этом случае, как и во многих других, он невидимой рукой направляется к цели, которая совсем и не входила в его намерения; при этом общество не всегда страдает от того, что эта цель не входила в его намерения. Преследуя свои собственные интересы, он часто более действенным образом служит интересам общества, чем тогда, когда сознательно стремит- 
ся делать это» [Smith 1976a: bk. 4, ch. 2] (рус. пер. цит. по: [Смит 2007: 442]). Конкурентные рынки и защищённые, хорошо определённые права собственности, объясняет Смит, направят общество так, что невидимая рука окажется способной осуществить свою магию: «Не от благожелательности мясника, пивовара или булочника ожидаем мы получить свой обед, а от соблюдения ими своих собственных интересов» [Smith 1976a: bk. 1, ch. 2] (рус. пер. цит. по: [Смит 2007: 77]).

Итак, с правильными институтами самые обыденные мотивы могут иметь возвышенные последствия.

\section{Конституция для мошенников}

Новые основания для законодательства и публичной политики не замедлили появиться. В своих «Опытах...» (1742) Дэвид Юм вывел следующую максиму: «При рассмотрении любой системы правительства $<\ldots>$ каждый человек должен предполагаться мошенником, то есть во всех своих действиях не имеющим иного интереса, кроме частного. Согласно этому интересу мы должны управлять им и посредством сего делать его, независимо от его неутолимой алчности и амбиций, союзником в достижении общей пользы» [Нume 1964: 117-118]. В схожем ключе Иеремия Бентам для дизайна публичной политики предлагает свой «принцип перекрёстка обязанностей и интереса: сделайте интересом каждого человека показывать < .. > такое поведение, показывать которое есть его обязанность» [Bentham 1962: 380]. «Введение в принципы морали и законодательства» - первая книга из той области знания, которую мы сегодня называем экономикой общественного сектора, и в ней Бентам описывает выводы из максимы Юма для публичной политики.

Хотя сдерживание мошенников остаётся лейтмотивом классических экономистов, они не верят, что экономические агенты и граждане и вправду аморальны. Совсем наоборот.

Юм был одним из первых, кто изучал эволюцию социальных норм; и в предложении, следующем прямо за максимой про мошенников, процитированной выше, он размышлял о том, как «странно, что эта максима должна быть верной в политике, хотя она ложна по факту» [Hume 1964:]. Смит в «Теории нравственных чувств» утверждал, «Какую бы степень эгоизма мы ни предположили в человеке, природе его, очевидно, свойственно участие к тому, что случается с другими, участие, вследствие которого счастье их необходимо для него, даже если бы оно состояло только в удовольствии быть его свидетелем» [Smith 1976b: 3] (рус. пер. цит. по: [Смит 1997: часть I, отдел I, глава I]). На практике политические меры, которые отстаивали классические экономисты, не отбрасывали этические и альтруистические мотивы. Бентам, как мы увидим, верил, что наказание должно быть «моральным уроком».

Описанное выше напряжение между предпосылкой о неограниченном эгоистическом интересе и эмпирической реальностью более сложных и возвышенных человеческих мотивов не беспокоило юристов двадцатого столетия, которые приняли парадигму Hoтo economicus. Холмс через несколько строк после того, как направил внимание своих студентов на «плохого человека», настаивал на том, что «закон является свидетелем и внешним хранилищем нашей моральной жизни» [Holmes 1897]. Юридическая практика сегодня, как и политика классических авторов, признаёт широкий набор общественных склонностей вместо того, чтобы ограничиваться интересом эгоистичного плохого человека. Регулирование рынка, например, сочетает штрафы за нарушение закона с публичным раскрытием информации о нарушениях, чтобы вызывать у виновных стыд.

Даже Макиавелли вводит идею порочных граждан, цитируя популярное выражение того времени «Говорят, что все люди дурны» - как разумное предположение, а не как свидетельство порочной человеческой природы. В «Рассуждениях...» Макиавелли отвергает это предположение на эмпири- 
ческой основе: «Наши же рассуждения относятся к тем народам, где испорченность широко ещё не распространилась и в которых доброе начало сильнее, чем дурное» - и добавляет: «[люди] не умеют быть ни вполне добрыми, ни целиком дурными» [Machiavelli 1984: 103, 121] (рус. пер. цит. по: [Mакиавелли 2004: 180, 197]); см. также: [Benner 2009]. Аристотель писал намного худшие вещи по этому поводу. «[М]ногие люди оказываются дурными и слабыми ввиду выгод и трусливыми в минуту опасности < ..> По большей части люди обижают, когда могут» [Aristotle 2006: 1382b7-9] (рус. пер. цит. по: [Тахо-Годи 1978: 82]).

Привлекательность конституции для мошенников проистекает поэтому не из того, что граждане являются мошенниками в действительности. Скорее, преследование собственного интереса рассматривается как хорошая или, по крайней мере, безвредная деятельность по сравнению с прочими, разрушительными «страстями», такими как религиозный пыл или жажда власти; и затем эмпирически делается заключение о том, что одни лишь добродетели дают недостаточное основание для хорошего управления на уровне национального государства.

В Средние века алчность считалась одним из наиболее страшных семи смертных грехов - взгляд, который стал ещё более распространённым с расширением коммерческой деятельности после XII века [Bloomfield 1952: 95]. Удивительно поэтому, что собственный интерес стал в конце концов рассматриваться в качестве достойного уважения мотива, и ещё более удивительно, что это изменение не имело отношения к развитию экономической науки, по крайней мере, поначалу. За год до того, как Адам Смит написал, как собственные интересы мясника, пивовара и пекаря помогли доставить обед к столу, доктор Джонсон у Джеймса Босуэлла выдал Ното есоnomicus такую похвалу: «Мало столь невинных занятий для человека, как зарабатывание денег» [Boswell 1980: 597].

Приведённое выше упоминание Смитом мясника, пивовара и пекаря часто используется как одна из его отсылок к невидимой руке. Но нужно помнить, что здесь же высказывается новая идея о том, что мотивы, отличные от собственного интереса, могут быть губительными: преследуя собственные интересы, индивид часто более действенным образом служит интересам общества, чем когда он сознательно стремится к этому.

Опасность войны и беспорядка сделала собственный интерес приемлемой основой для хорошего правления. В ходе XVII века войны были ответственны за большую долю европейской смертности, чем в каком-либо другом веке письменной истории, не исключая и тот век (к счастью, недавно закончившийся), который Раймон Арон назвал веком тотальных войн. После десятилетия войны между английскими парламентариями и роялистами Гоббс (1651 г.) пытался найти «страсти, склоняющие людей к миру» и обнаруживал их в «страхе смерти; желании вещей, необходимых для хорошей жизни; и надежде приобрести их своим трудолюбием» [Hobbes 2005: 104 (ch. 13)] (pус. пер. цит. по: [Гоббс 1991: 98]). Мошенники были предпочтительнее святых.

Ещё одна причина привлекательности подхода конституции для мошенников теснее связана с работами Макиавелли и практическим поворотом в политической теории, который он отстаивал. «Я предпочёл следовать правде не воображаемой, а действительной, - писал он, — в отличие от тех многих, кто изобразил республики и государства, каких в действительности никто не знавал и не видывал» [Machiavelli 1900: 92] (рус. пер. цит. по: [Макиавелли 2004: 101]). Полтора века спустя Барух Спиноза начнёт свой «Политический трактат» с утверждения: «[Н]икто не считается менее способным к управлению государством, нежели теоретики или философы < ..> Ибо людей они берут не такими, каковы те суть, а какими они хотели бы их видеть» [Spinoza 1958: 261] (рус. пер. цит. по: [Спиноза 1957: 287]). Через поколение после Спинозы Мандевиль напишет введение к своей «Басне...» почти тем же языком. 
Но не одним лишь реализмом необходимо руководствоваться в отступлении от добродетели как основы хорошего управления. Если «другие», которыми мы хотим править, принадлежат к нашему роду (соседи, друзья), тогда забота об их благополучии и желание избежать социальных санкций или возмездия за нарушение социальных норм должна принуждать нас действовать так, чтобы учитывать их интересы и улучшать управление. Но с ростом городов и консолидацией национальных государств метафора политии как семьи или даже рода становится нереалистичной. Масштаб правления слишком сильно расширяется. С ростом размера наций и размаха рынков индивиды взаимодействуют не с парой дюжин семей, но с сотнями незнакомцев, а косвенно — с миллионами других людей.

Новая политическая парадигма является ответом на беспокойство о том, что с ростом числа взаимодействующих незнакомцев этические и альтруистические мотивы окажутся недостаточными в качестве основы для хорошего управления, поэтому необходимо принять систему сдержек и стимулов для гражданских добродетелей. Именно эта недостаточность гражданских добродетелей, а не их отсутствие или нерелевантность, заботила Макиавелли. Классические экономисты, которые выработали новую политическую парадигму, знали, что никакая экономика или социальная система не сможет функционировать хорошо в отсутствие добродетелей. Даже скандально известный Мандевиль убеждал своих читателей в этом: «Я изложу как первый принцип, что во всех обществах, больших или малых, долг каждого члена общества - быть хорошим; добродетель должна поощряться, а порок - порицаться, законы —исполняться, а нарушители — наказываться» [Mandeville 1988b: 407].

Аналогично «естественная свобода», которую принимал Смит, была ограничена моралью. Его знаменитые строки: «Каждому человеку <..> предоставляется совершенно свободно преследовать по собственному разумению свои интересы», — были дополнены оговоркой: пока он не нарушает законов справедливости. Справедливость, объяснял Смит, требует «ограждать по мере возможности каждого члена общества от несправедливости и угнетения со стороны других его членов» [Smith 1976a: bk. 4, ch. 9] (рус. пер. цит. по: [Смит 2007: 647]). Мандевиль выразил ту же идею в запоминающихся стихах, сравнив человеческие наклонности с неограниченным ростом виноградной лозы: «Так и порок полезен людям, / Когда он связан правосудьем» [Mandeville 1924: 37] (здесь стихотворный перевод дается по: [Субботин 1986: 130]).

Классические экономисты поэтому были вполне в курсе того, что модель, позже названная Ното economicus, упрощала то, что они знали о человеческом поведении, но позволяла прояснить, как политические меры, нацеленные на изменение экономических стимулов, способны влиять на поведение. Джон Стюарт Милль в числе последних классических экономистов прописывал поэтому границы и ключевые предположения экономической экономики, которые и до недавнего момента принимались многими: «[Политическая экономия] не рассматривает < ..> в целом человеческую природу <...> Она касается человека только как существа, которое желает обладать богатством <...> Она предсказывает только те явления < ..> которые имеют место как следствие стремления [индивида] к богатству. Она полностью абстрагируется от всех других человеческих страстей и побуждений» [Mill 1844: 97] (рус. пер. цит. по: [Милль 2007: 1001]). Милль назвал это условным определением человека.

Становление неоклассической школы в экономике в конце XIX века не изменило статуса эгоистического интереса как удобной, но эмпирически неверной абстракции. Ф. И. Эджуорт, основатель неоклассической парадигмы, выразил этот взгляд в своей «Математической психике»: «Первый принцип экономической науки состоит в том, что каждый агент следует лишь собственному эгоистическому интересу» [Edgeworth 1881: 104]. Но в том же предложении признавалось, что «счастье остальных, в сравнении с собственным счастьем агента, не считается за ноль, но и не считается за единицу». 
Однако, как и Милль, Эджуорт считал, что политическая экономика может изучать эффекты стимулов, которые апеллируют к максимизирующей богатство стороне индивида, без учёта прочих мотивов, которые оба экономиста признавали, но считали лежащими за пределами экономической науки.

\section{Сепарабельность нравственных чувств и материальных интересов}

Возможность, которую классические экономисты (и большинство экономистов после них) упустили, состояла в том, что моральное и прочее просоциальное поведение может быть затронуто - не исключено, что в неблагоприятную сторону, - основанной на стимулах политикой, разработанной для управления эгоистическим интересом. «Почему должно быть так, - задавался вопросом Кеннет Эрроу в своей рецензии на книгу Ричарда Титмуса "Отношение дара: от человеческой крови до социальной политики”, - что создание рынка крови вдруг обесценит альтруизм, заключённый в донорстве крови?»[Arrow 1972: 351]. Вплоть до недавнего момента большинство экономистов были настолько уверены в ответе, что даже не считали нужным отвечать. Но для Эрроу это был «в действительности эмпирический вопрос, а не вопрос начальных предпосылок».

Для большинства экономистов, однако, начальной предпосылкой по умолчанию является то, что стимулы и мораль аддитивно сепарабельны, — этот математический термин означает, что эффект изменения одной величины не зависит от уровня другой величины. Когда две вещи аддитивно сепарабельны, они не синергетичны - каждая положительно влияет на другую, как дуэт оказывается лучше суммы составляющих его частей, а не наоборот.

Я вернусь к предпосылке о сепарабельности в последующих главах. Мы уже видели, что предпосылка о сепарабельности может завести нас не туда. Чувство долга пожарного по отношению к жителям Бостона не является сепарабельным от его эгоистичного стремления получать большую зарплату; политика же, которая обращается ко второму чувству, по-видимому, ослабляет первое. Целое в этой ситуации оказывается меньше, чем сумма частей. Именно такую возможность основанная на стимулах политическая парадигма и просмотрела.

Мы редко употребляем слово «сепарабельность» в нашей повседневной речи, так что пример не повредит. Эми Вреснивски, Барри Шварц и их соавторы изучали мотивы, которые заставляют молодых мужчин и женщин поступать в Военную академию США в Вест-Пойнте [Wrzesniewski et al. 2014]. Они использовали опросники, которые раздавались академией будущим кадетам из девяти когорт (разница между когортами составляла один год), чтобы определить, поступает ли кадет в Вест-Пойнт по инструментальным мотивам («чтобы получить лучшую работу» или «из-за репутации Вест-Пойнта», которая предположительно является плюсом в резюме) либо по внутренним мотивам («желание быть военным офицером», «личное развитие»). Затем они проследили судьбу 11320 кадетов и спустя 10 лет после выпуска выяснили, как мотивы при поступлении коррелировали с дальнейшими успехами выпускников.

На рис. 2 показано, как инструментальные мотивы статистически связаны с вероятностью стать кадровым офицером (одна из мер успеха) для кадетов с высокими, средними и низкими внутренними мотивами для поступления в Вест-Пойнт. О чем говорят данные?

Во-первых, заметим, что для среднего уровня инструментальных мотивов (0 по горизонтальной оси) наличие сильных внутренних мотивов для поступления связано с существенно более высокой вероятностью получения кадрового звания (линия для высокой внутренней мотивации показывает более высокую вероятность успеха в достижении звания кадрового офицера). Во-вторых, для тех, чьи внутренние мотивы очень низки (нижняя, возрастающая линия), более высокие инструментальные мотивы также связаны с более высокой вероятностью стать кадровым офицером. 


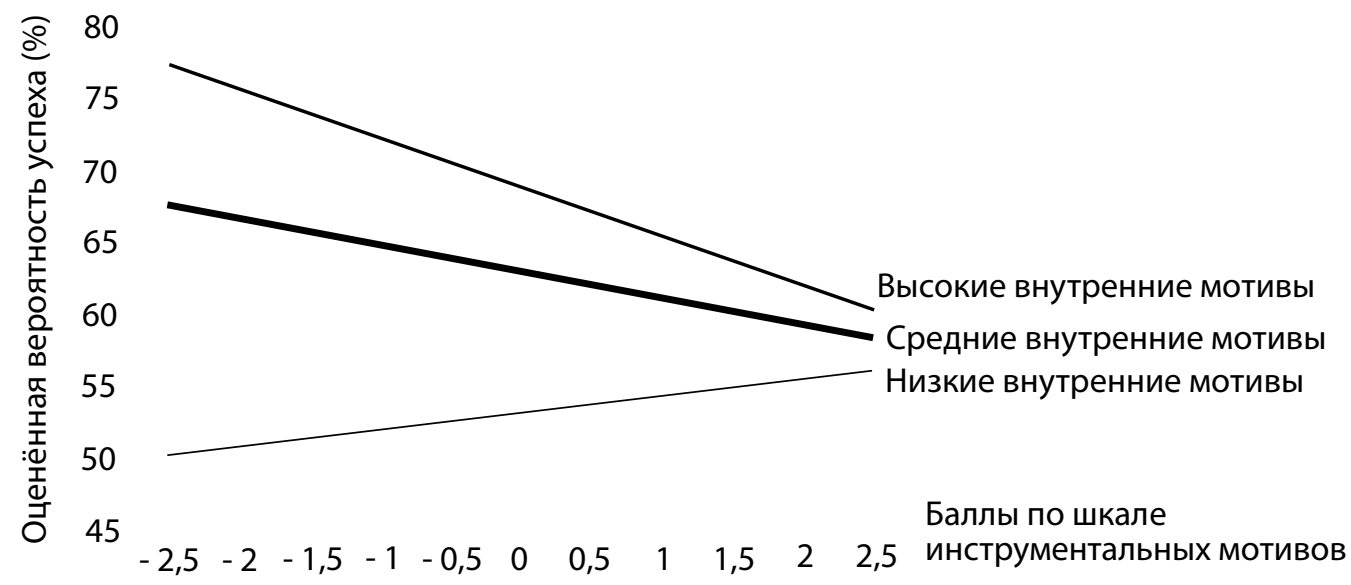

Источник: данные [Wrzesniewski et al. 2014].

Примечание: мера успеха по вертикальной шкале - оценённая вероятность того, что кадет станет кадровым офицером, поэтому каждая точка на линиях отражает ожидаемый успех для кадета с данным уровнем баллов по инструментальным мотивам и уровнем баллов по внутренним мотивам, указанным в подписи к линии. Баллы по инструментальным мотивам измеряют эгоистические причины для поступления в Вест-Пойнт. Баллы по внутренним мотивам измеряют внутренние мотивы, описанные в тексте. Высокие баллы по этому фактору означают 95-й перцентиль; низкие баллы означают 5-й перцентиль.

Рис. 2. Инструментальные и внутренние мотивы

как субституты в жизненном успехе кадетов Вест-Пойнта после окончания учебного заведения

Но самым неожиданным является третье наблюдение: для кадетов со средними или высокими внутренними мотивами (две убывающие линии) наличие более высоких инструментальных мотивов приводит к худшим результатам. Внутренние и инструментальные мотивы не являются аддитивно сепарабельными, они - субституты: больше одних мотивов уменьшает положительный эффект от других.

Как военная академия может использовать эту информацию для тренировки офицерского состава? Если приёмная комиссия считает, что потенциальным рекрутам не хватает внутренних мотивов, она должна руководствоваться нижней линией. В результате академия будет апеллировать к их инструментальным мотивам и подчёркивать ценность репутации Вест-Пойнта для получения работы вне армии. Но если комиссия будет знать, что многие кадеты - это идеалистически настроенные молодые мужчины и женщины, которые желают служить своей стране (а так оно и есть), то ей стоит руководствоваться двумя верхними линиями и снизить акценты на инструментальных мотивах.

Экономисты постоянно либо делают первое предположение (что внутренние мотивы отсутствуют), либо, если признают другие мотивы, помимо эгоистического интереса, предполагают (обычно неосознанно), что эти два набора мотивов сепарабельны. Но если бы это было действительно так, то все три линии на рисунке были бы возрастающими и параллельными.

Неявная предпосылка о сепарабельности заставила экономистов игнорировать две важные возможности: (1) использование стимулов для направления эгоистического интереса к общественной пользе способно подорвать гражданские добродетели или мотивационную предрасположенность к ним, и (2) при некоторых условиях этические и альтруистические соображения могут работать совместно и синергетически поддерживать выгодные для общества исходы.

\section{Рынки как свободные от морали зоны}

Повсеместное (хотя, по большей части, неосознанное) принятие предпосылки о сепарабельности означает, что предположения об экономическом поведении не обязаны соотноситься с фактами и наблюде- 
ниями о человеческой психологии. С конца XVIII века экономисты, политические теоретики и конституционные мыслители принимали максиму Юма и рассматривали Hoтo economicus в качестве рабочей предпосылки о человеческом поведении. Отчасти по этой причине конкурентные рынки, хорошо определённые права собственности и эффективные и - с XX века - демократически подотчётные страны стали расцениваться как критические элементы управления. Хорошие институты заменили хороших граждан в качестве главного условия хорошего управления. В экономике цены стали выполнять работу морали.

Теперь нужен был лишь небольшой шаг для того, чтобы заключить: хотя этические соображения и забота о других должны руководить действиями в рамках семьи или по отношению к другим гражданам, это совсем необязательно при совершении покупок или зарабатывании на жизнь. Алиса из сказок Льюиса Кэрролла приняла выводы экономистов близко к сердцу. Когда Герцогиня сказала: «Любовь, любовь, ты движешь миром...» - Алиса шепнула: «А мне казалось, кто-то говорил, будто самое главное — не соваться в чужие дела» [Carroll 2000: 92] .

Как стремление заниматься своими делами заняло место любви? Это классический конституционный вопрос, которым задавались Бентам, Юм, Смит и прочие, и этот вопрос всё ещё составляет святой Грааль основанного на стимулах политического дизайна. Идея заключается в поиске законов и других политических мер, стимулирующих заинтересованность индивидов в собственных интересах, но вместе с тем заставляющих учитывать эффекты, которые предпринимаемые действия оказывают на остальных.

На экономическом жаргоне это означает: каждый агент интернализует все издержки и выгоды от своего действия, в том числе эффекты на других, а не просто будет учитывать свои личные выгоды и издержки, то есть те, которые касаются его собственных прибылей и убытков, боли и удовольствия.

Если индивид принимает во внимание эффекты своих действий на других, то он обладает альтруистическими предпочтениями. Вариации золотого правила и прочих этических предписаний являются одним из способов преследования этой цели (или, как сказала Герцогиня, любви).

Другой подход, при котором каждый занимается своим делом, как это показал Бьюкенен в примере о продавце по соседству, опирается на цены, работающие вместо морали. Этот подход, в принципе, может работать, если выполняются два условия.

Во-первых, всё, что важно для людей при принятии ими решения, должно иметь цену. Соответственно требование «всё имеет свою цену» следует применять не только к товарам (одинаковые товары нужно продавать по одинаковой цене), но и к остальным элементам трансакции, например, к шуму, который вынуждены терпеть живущие рядом с заводом люди, а также к газовым выхлопам.

Во-вторых, налоги, субсидии и прочие политические меры должны влиять на цены таким образом, чтобы цена, которую покупатель платит за то, чтобы получить товар, включала все издержки, которые кто-либо понесёт в результате производства и использования этого товара, а продавец, аналогичным образом получал бы все выгоды (которые получит покупатель или кто-то третий) от продажи товара. Цены должны измерять все общественные выгоды и издержки от производства и продажи товара, а не только частные издержки покупателя и продавца. Назовём это второе условие «правильные цены».

При выполнении этих двух условий подход «каждый занимается своим делом» означает попросту то, что, руководствуясь ценами, эгоистичные люди «претворят в жизнь» (хотя и неосознанно) идеал обще-

6 Пер. Н. М. Демуровой; цит. по: [Кэрролл 1991]; см.: http://lib.ru/CARROLL/alisa.txt — Примеч. ред. 
ственного устройства: они примут во внимание все эффекты своих действий на других. Именно это имел в виду Мандевиль, когда огорошил своих читателей утверждением о том, что «ловкое управление хитрого политика» позволит превратить «частные пороки» в «общественные выгоды».

Смит пошёл дальше, чем Мандевиль. Удивительная идея, лежащая в основе описанной им невидимой руки, заключается в том, что при наличии правильных институтов «ловкий политик» становится излишним: определённые в ходе рыночной конкуренции цены сами сделают всю работу, без всякой помощи субсидий, налогов или иных государственных мер. Смит подчеркнул, что конкуренция как между покупателями, так и между продавцами является критически важной для этого результата, и предупредил о том, как монополии и картели могут помешать невидимой руке: «Представители одного и того же вида торговли или ремесла редко собираются вместе даже для развлечений и веселья без того, чтобы их разговор не кончился заговором против публики или каким-либо соглашением о повышении цен» [Smith 1976a: bk. 1, ch. 10] (рус. пер. цит. по: [Смит 2007: 174]). Смиту также были известны многие области политики, которые лежат за пределами достижимого невидимой рукой (такие, как предоставление общественного образования).

Экономисты со времён Смита подчёркивали, что необходимые для работы невидимой руки институциональные условия гораздо больше простой конкуренции. Чтобы для каждого товара установилась правильная цена, все экономические взаимодействия должны управляться тем, что экономисты называют полными контрактами. Это означает, что каждый аспект обмена - всё, что ценится кем-либо из обменивающихся партнёров или какой-либо третьей стороной, — должен иметь цену, которая включается в контракт об обмене. Полные контракты прописывают требования и обязательства таким образом, что каждый актор «получает» все выгоды и издержки, возникающие вследствие его или её действий, в том числе те, которые накладываются на других.

Если бы контракты были полными, равновесный результат конкуренции между эгоистичными индивидами гарантировал, что всё имеет цену и что цены правильные. В итоге конкурентные рынки осуществляли бы результаты, называющиеся Парето-эффективными, что означает, что не существует другого технически достижимого исхода, при котором хотя бы одному из индивидов было бы лучше, а всем остальным - не хуже.

Описанные мною выше рассуждения впервые были проведены Кеннетом Эрроу и Жераром Дебре в рамках того, что я буду называть теоремой о невидимой руке, за которую они получили Нобелевские премии. Аксиомы первой фундаментальной теоремы экономики благосостояния в том виде, в каком она известна экономистам, - особенно предпосылка о полноте контрактов - прояснили природу идеализации, при которой государственная интервенция не была необходима для корректирования провалов рынка, а именно ситуаций, когда нескоординированные обмены или иная экономическая деятельность приводят к Парето-неэффективным исходам.

Менее известным, но более важным для наших целей, является тот факт, что в этом моделируемом мире, как указывали Хайек и Бьюкенен, хорошее управление не требовало добродетели. Первая фундаментальная теорема верна независимо от предпочтений людей, даже если их предпочтения аморальны или эгоистичны.

Рынки поэтому получают моральную экстерриториальность, похожую на то, как законы принимающей страны не работают на территории иностранных посольств. Можно не одобрять и даже осуждать небрежного родителя или гражданина, который нарушил законы для собственной выгоды. Но осуждать эгоистичного продавца? Или эгоистичного банкира? Пока всё имеет правильную цену, преследование собственного интереса на рынке ограничено - правильными ценами - и должно учитывать эффект 
предпринятых действий на остальных. Бьюкенен поэтому не испытывал чувства стыда за своё безразличие к благосостоянию продавца фруктов.

Добровольная природа трансакций и эффективность их исходов (при выполнении предпосылок теоремы) делает конкурентный обмен особой областью, в которой приостанавливается действие нормативных стандартов, обычно применяемых к отношениям граждан и членов семьи. Обобщая безразличие Бьюкенена и объявляя рынки свободной от морали зоной, философ Давид Готье утверждает, что «мораль возникает из-за провала рынка $<\ldots>$ Мораль неприменима к рыночным взаимодействиям в условиях совершенной конкуренции» [Gauthier 1986: 84, 96] $]^{7}$.

Итак, алчность в обёртке собственного интереса была укрощена и из порока превратилась в ещё один мотив, вроде предпочтения в выборе мороженого.

\section{Мошенникомика}

Но что, если, в отличие от Бьюкенена и его продавца арбузов, две стороны не согласны по поводу прав собственности, связанных с обменом? Это происходит, когда контракты неполны и некоторые стороны обмена не имеют цены: вы дышите моим табачным дымом; пчёлы фермера Джонса опыляют яблони фермера Брауна. Когда Джонс обменивает свой мёд на яблоки Брауна, он обычно не берёт с него цену за услуги по опылению, предоставленные его пчёлами. Эта помощь фермеру Брауну и прочим садоводам оказывается внешним эффектом (его ещё называют «экстерналия»), то есть прямым эффектом между экономическими акторами, на который не назначается цена и который не покрывается (поэтому является внешним) прописанными в контракте условиями обмена. Услуги пчёл не включаются в цену, получаемую Джонсом за свой мёд. В результате не выполняются условия «у всего есть цена» и «цена правильная», и частные выгоды Джонса от продажи мёда оказываются меньше, чем общественные выгоды от его фермы (в них не включаются услуги по опылению, оказываемые пчёлами). Таким образом, производится неэффективно мало мёда (и услуг по опылению).

Контракты также неполны (или отсутствуют) при командной работе (например, в исследованиях и при оказании юридических услуг) и в добровольном предоставлении общественных благ (например, в благоустройстве района и приверженности социальным нормам). Общественные блага - радиопередачи или идеи - являются крайней формой неполных контрактов, поскольку (по определению) они одновременно неконкурентны (то, что у меня будет больше, ничего не отнимает у вас) и неисключаемы (нельзя ограничить наслаждение общественным благом; если оно есть у вас, оно есть и у меня).

В таких случаях, как опыление пчёлами фермера Джонса сада фермера Брауна или предоставление общественного блага, нерегулируемые рыночные взаимодействия между эгоистичными акторами не приведут к эффективным исходам (слишком мало опыления, слишком мало общественного блага). Но это не означает, что эгоистическая конкуренция на рынке должна быть ограничена; это показывает, что публичная политика должна взять на себя задачу назначения правильных цен.

В начале XX века Альфред Маршалл и Артур Пигу впервые объяснили экономическую логику того, как цены интернализуют эффекты действий одних акторов на других, даже в ситуации провала рынка. В случае неполноты контрактов Маршалл и Пигу отстаивали необходимость налогов на отрасль за ущерб окружающей среде (внешние издержки), который отрасль принесла другим, и субсидий для фирм, обучающих рабочую силу, что принесёт выгоду другим фирмам, когда работник сменит рабочее место.

7 Для завершённости аргумента Д. Готье стоило добавить фразу «в предположении полноты контрактов», что, как сам Готье сообщил мне, он и имел в виду. - Примеч. автора. 
Фермер Джонс получит субсидию, равную ценности, которую приносит опыление его пчёлами сада фермера Брауна, так что выгоды фермера Джонса (вместе с субсидией) будут равны полным социальным выгодам от его пасеки. Оптимальными налогами и субсидиями называются такие, которые компенсируют экономическим акторам выгоды, получаемые другими, от их действий и делают их ответственными за те издержки, что понесут другие, когда эти выгоды и издержки никак бы не отразились на частных выгодах и издержках актора.

В качестве одного из примеров можно назвать «зелёные» налоги, которые «заставляют загрязнителя платить» за урон окружающей среде. Когда оптимальные стимулы достижимы, они прямо осуществляют сформулированный Бентамом принцип «сочетания обязанности и интереса», то есть изменяют материальные мотивы, которыми руководствуются в своих решениях индивиды, так, чтобы примирить эгоистический интерес с общественными целями. Оптимальные налоги и субсидии, которые отстаивали Маршалл, Пигу и экономисты после них, являются поэтому субститутами для полных контрактов, попыткой распространить сферу действия невидимой руки на те случаи, для которых необходимые для работы невидимой руки предпосылки нарушены. В идеале подобные налоги и субсидии установят цену на всё, что важно, и сделают это правильно.

Получившееся в итоге последовательное руководство для проведения политики недвусмысленно указывает на те действия, которые необходимы для принуждения граждан действовать так, как если бы они были хорошими, а точнее, какие необходимы стимулы и ограничения для того, чтобы побудить эгоистичного индивида действовать так, как если он учитывал эффекты своих поступков на остальных точно так же, как учитывает эффекты для самого себя. Мудрый политик при этом подходе является не аристотелевским законодателем, который стремится воодушевить народ, но макиавеллиевским республиканцем, который издаёт правильные законы, вынуждающие людей действовать так, как если бы они были хорошими.

В преподавании экономической науки поэтические примеры, вроде пасеки и сада, повсеместны. Пример общественного блага из учебника - это маяк, чей свет может быть виден всеми, если он виден хоть кому-то. Проблема неполных контрактов в том, что это не какие-то исключения на периферии экономики. Мы увидим, что неполные контракты служат важной частью работы рынков труда, кредита, информации и прочих центральных арен капиталистической экономики.

Тот факт, что неполные контракты представляют собой правила, а не исключения, запускает цепь выводов, которые мы должны сделать для себя по поводу использования и ограничений стимулов, так что стоит остановиться и поразмышлять о неполных контрактах ещё немного. Информация об объёме и качестве товара или услуги, предоставляемых в ходе обмена, очень часто является асимметричной, то есть неизвестной обеим сторонам, или неверифицируемой, то есть хотя и известной обеим сторонам, но недоступной для использования в суде при оспаривании контракта. Если это так, некоторые аспекты обмена не попадут в контракт: контракт будет неполным. Как заметил ещё Эмиль Дюркгейм, «не всё в контракте контрактно» [Durkheim 1967: 189]. В результате провалы рынка не ограничатся ущербом для окружающей среды, но будут возникать в каждодневных обменах, составляющих суть капиталистической экономики, - на рынках труда и кредита. Невозможно написать поддающийся исполнению контракт, согласно которому работник должен работать много и усердно. Кредитные контракты не могут быть исполнены, если у заёмщика ничего нет [Bowles 2004].

Примеры рынков труда и кредита имеют общую структуру: принципал (наниматель или кредитор) хотел бы принудить агента (работника или заёмщика) действовать таким образом, который был бы выгоден для принципала, но шёл вразрез с интересами агента (работать усердно, использовать заёмные средства способом, который максимизирует вероятность выплаты кредитору, а не ожидаемую отдачу 
для заёмщика). Поскольку информация об уровне приложенных усилий и использовании денег либо неизвестна принципалу, либо не может быть использована в суде, конфликт интересов между двумя сторонами не поддаётся разрешению с помощью составления полного и исполнимого контракта.

Когда контракты неполны, фактические условия сделки в значительной степени определяются стратегическим взаимодействием между сторонами, а не судами. Результат этого взаимодействия зависит от переговорной силы двух сторон и их социальных норм. Та же проблема возникает, когда фермер отдаёт часть своего урожая землевладельцу. Во всех трёх случаях агент (в том числе фермер-издольщик) не является собственником результатов своего труда: кредитор принимает на себя убыток, который заёмщик не может возместить; наниматель получает выгоду от усердной работы работника, но не может забрать у него зарплату назад, если работа оказалась в итоге несделанной.

Итак, для значительной части современной капиталистической экономики предпосылка о полноте контрактов оказывается нарушенной. Существенным вкладом математического представления работы рыночной экономики, которое позволило доказать теорему о невидимой руке, стало прояснение того, что же на самом деле нужно для работы идеи Адама Смита. Вот как Эрроу объяснял позднее значение своей теоремы: «Есть длинный и <..> внушительный ряд экономистов, от Адама Смита до нашего времени, которые пытались показать, как децентрализованная экономика, основанная на эгоистическом интересе и руководимая ценовыми сигналами, является совместимой с последовательным приложением экономических ресурсов, которое в хорошо определенном смысле считалось бы лучшим по сравнению с большим классом альтернативных возможных приложений < ..> Важно не просто знать, что это правда, но и почему это может быть правдой» ${ }^{8}$ [Arrow, Hahn 1971: vi-vii].

Благодаря Эрроу и остальным условия, при которых это «может быть правдой», - не только конкуренция, но и полные контракты для всего, что имеет значение, - теперь признаются в высшей степени ограничительными и показывают, сколь маловероятно, что политика бескомпромиссного laissez-faire приведёт к эффективному исходу. По своему опыту я знаю, как сложно авторам вводных учебников по экономике найти хотя бы один эмпирический пример рынка, похожий в какой-то степени на модель, на которой основана теорема.

\section{От Макиавелли к дизайну механизмов}

Помогут ли правильно рассчитанные оптимальные субсидии и налоги в стиле Маршалла- Пигу заменить полные контракты, которые нельзя заключить на рынках труда, кредита и прочих товаров? Если помогут, то цены всё же способны выполнить работу морали; область, в которой «давать людям делать своё дело» оказывается хорошей политикой, значительно расширится.

На сегодняшний день предложено множество хитроумных систем стимулов. Для этой цели есть даже специальная наука, которая называется «дизайн механизмов», где «механизм» — это попросту набор прав собственности, стимулов, ограничений и прочих правил, управляющих взаимодействием людей. Но, как мы увидим позже (см. главу VI этой книги), предположения, которые требуются для того, чтобы эти механизмы работали, настолько же далеки от реальных экономик, как и предположения первой фундаментальной теоремы экономики благосостояния. Дизайн механизмов пока не разработал таких стимулов, которые сделали бы этические и альтруистические мотивы излишними, и вряд ли когданибудь разработает. Юристам и политикам пока не даётся способность заставлять эгоистичных людей гарантированно вести себя так, как если бы их волновали эффекты их действий на остальных. Почему не даётся, я объясню в главе VI.

8 Курсив оригинала. - Примеч. пер. 
Неудивительно, что, не считая домашних работ по предмету «экономика», люди не воспринимают Homo economicus всерьёз. Работодатели предпочитают нанимать исполнительных сотрудников; банки предпочитают одалживать деньги тем заёмщикам, которые будут вести свои дела, как обещано, а не отвлекаться на рискованные проекты. И опять все знают, что вопреки содержанию учебников по экономике, «контракт сам по себе недостаточен». Дюркгейм написал ещё столетие назад: «Регулирование контракта < ..> изначально имеет социальное происхождение» [Durkheim 1967: 189]. Он повторял общее место о том, что рукопожатие имеет значение; если это не так, экономика будет страдать.

В статье, объясняющей теорему о невидимой руке, Эрроу писал: «В отсутствие доверия < ..> возможности для взаимно благоприятного сотрудничества будут упущены <...> Нормы социального поведения, в том числе этические и моральные кодексы [могут быть] < ..> реакцией общества для компенсации провалов рынка» [Arrow 1971: 22]. Иными словами, поскольку контракты неполны, мораль должна делать работу цен, а не наоборот.

Мысль Эрроу состоит в том, что социальные нормы и моральные кодексы должны сгладить провалы рынка, когда они работают на интернализацию издержек и выгод, налагаемых действиями индивида на остальных. Несмотря на неполноту контрактов, главные рынки в современной экономике - рынки труда, кредита и знаний - иногда работают сравнительно неплохо, потому что социальные нормы и альтруистические мотивы воспитывают в людях положительную рабочую этику, обязательство говорить правду о качествах проекта или информации и держать своё слово.

Важность норм и прочих социальных мотивов касается не только того, что мы привыкли называть провалами рынка. Нормы важны и на тех аренах социальной жизни, на которых эффекты действий на других не управляются контрактом: долгосрочные климатические эффекты от выбора стиля жизни, возникновение устойчивых к лекарствам штаммов из-за чрезмерного использования антибиотиков, а также дорожные пробки возникают из-за совершаемых людьми выборов. Необходимость дополнения хорошего управления социальными нормами будет лишь возрастать по мере того, как эти и другие проблемы будут вставать перед нами во всём их объёме. Меняющаяся природа самой работы - от производства вещей к обработке информации и предоставлении услуг, например, - также указывает на то, что неполнота контрактов в наших экономиках будет лишь возрастать.

Классические экономисты были правы, считая, что этические и альтруистические мотивы недостаточны для хорошего управления экономикой, в которой множество сделок осуществляется между незнакомцами. Никто теперь не сомневается в правоте замечания Адама Смита о том, что эгоистичный интерес должен быть усмирён для достижения цели, которая совсем не входила в намерения актора. Но Йозеф Шумпетер, один из первопроходцев экономической теории инноваций и технического прогресса, также был прав, когда писал, что «никакая система не способна работать <...> если в ней каждый <..> руководствуется лишь собственными утилитарными интересами» [Schumpeter 1950: 448]. В этом случае речь идёт не о семье или государстве - об областях, в которых роль этических и альтруистических мотивов широко признана, а о работе капиталистической фирмы.

Макиавелли опередил предписание Руссо рассматривать «людей как они есть» более чем на два столетия (а дизайн механизмов - более чем на четыре столетия) и поставил перед республиканским законодателем задачу разработать структуру управления, позволяющую людям с «обычными и естественными нравами» выбирать такие действия, результатом которых станет хорошо управляемая республика. Эта идея была важным вкладом в понимание того, как должна разрабатываться политика и как нужно писать законы. Но того же нельзя сказать о радикальном расширении этой хорошей идеи сначала Мандевилем, а затем экономистами, которые сочетают профессиональное безразличие к природе индивидуальных предпочтений с излишней уверенностью в том, что хитроумные стимулы способны заставить даже аморальных и эгоистичных граждан действовать к общей пользе. 
Этические и альтруистические мотивы всегда были неотъемлемой частью хорошо управляемого общества, и в будущем их значение лишь возрастёт. Политические меры, игнорирующие этот факт и безразличные к характеру предпочтений, которыми руководствуются люди в своих действиях, могут подорвать основы общества. Именно поэтому политикам стоит обратить внимание на реакцию пожарных на штрафные санкции брандмайора и на реакцию родителей, которые забирали своих детей из детсада позже после введения штрафов.

На следующих страницах мы поставим себя на место аристотелевского законодателя, который хочет действовать в наших интересах, пытается управлять хорошо и знает, что стимулы и ограничения, хотя и необходимы для любого социального порядка, никогда не будут достаточны и могут даже иметь непредвиденные негативные последствия для этических мотивов. В глазах законодателя политический инструментарий, основанный на максиме об эгоистическом интересе и разработанный для дурных людей и мошенников, может оказаться частью проблемы.

\section{Литература}

Аристотель. 1983. Сочинения: В 4 т. Т. 4. М.: Мысль.

Бентам И. 1998. Введение в основания нравственности и законодательства. М.: РОССПЭН.

Бьюкенен Дж. 1997. Конституцฺия экономической политики. Расчёт согласия. Границы свободы. М.: Таурус Альфа.

Гоббс Т. 1991. Сочинения: В 2 т. Т. 2. М.: Мысль.

Конфуций. 2000. Изречения. Книга песен и гимнов. М.: АСТ.

Кэрролл Л. 1991. Алиса в Стране чудес. М.: Наука.

Макиавелли Н. 2004. Сочинения исторические и политические. Сочинения художественные. Письма. M.: ACT.

Мандевиль Б. 1974. Басня о пчёлах. М.: Мысль.

Милль Дж. С. 2007. Основы политической экономии с некоторыми приложениями к общественной философии. М.: ЭКСМО.

Руссо Ж.-Ж. 1969. Трактатьл. М.: Наука.

Смит А. 1997. Теория нравственных чувств. М.: Республика.

Смит А. 2007. Исследование о природе и причинах богатства народов. М.: ЭКСМО.

Спиноза Б. 1957. Избранные произведения:В 2 m.. Т. 2. М.: Государственное издательство политической литературы.

Субботин А. Л. 1986. Бернард Мандевиль. М.: Мысль.

Тахо-Годи А. А. (отв. ред.) Античные риторики. М.: Изд-во Московского университета, 1978. 
Хайек Ф. 2011. Индивидуализм и экономический порядок. Челябинск: Социум.

Aristotle. 1962. Nicomachean Ethics. Translated by Martin Ostwald. Indianapolis: Bobbs-Merrill.

Aristotle. 2006. On Rhetoric: A Theory of Civic Discourse. Translated by George A. Kennedy. Oxford: Oxford University Press.

Arrow K. J. 1971. Political and Economic Evaluation of Social Effects and Externalities. In: Intriligator M. D. (ed.) Frontiers of Quantitative Economics. Amsterdam: North Holland; 3-23.

Arrow K. J. 1972. Gifts and Exchanges. Philosophy and Public Affairs. 1 (4): 343-362.

Arrow K. J., Hahn F. H. 1971. General Competitive Analysis. Advanced Textbooks in Economics. Vol. 12. San Francisco: Holden-Day.

Belkin D. 2002. Boston Firefighters Sick — or Tired of Working. Boston Globe, January 18. URL: https:// www.bostonglobe.com/

Benner E. 2009. Machiavelli’s Ethics. Princeton, NJ: Princeton University Press.

Bentham J. 1962. The Works of Jeremy Bentham. Vol. 8. Edited by J. Bowring. New York: Russell and Russell.

Bloomfield M. 1952. The Seven Deadly Sins. East Lansing: Michigan State University Press.

Boswell J. 1980 [1791]. Life of Johnson. Edited by R. W. Chapman. Oxford: Oxford University Press.

Bowles S 2004. Microeconomics: Behavior, Institutions, and Evolution. Princeton, NJ: Princeton University Press.

Buchanan J. 1975. The Limits of Liberty. Chicago: University of Chicago Press.

Carroll L. 2000. The Annotated Alice: The Definitive Edition of "Alice's Adventures in Wonderland" and "Through the Looking-Glass" by L. Carroll. New York: Norton.

Confucius. 2007. The Analects of Confucius. Translated by Burton Watson. New York: Columbia University Press.

Dumont L. 1977. From Mandeville to Marx: The Genesis and Triumph of Economic Ideology. Chicago: University of Chicago Press.

Durkheim E. 1967 [1902]. De la Division du Travail Social. Bibliothéque De Philosophie Contemporaine. Paris: Presses universitaires de France.

Edgeworth F. Y. 1881. Mathematical Psychics: An Essay on the Application of Mathematics to the Moral Sciences. London: Kegan Paul.

Gasiorowska A., Zaleskiewicz T., Wygrab S. 2012. Would You Do Something for Me? The Effects of Money Activation on Social Preferences and Social Behavior in Young Children. Journal of Economic Psychology. 33 (3): 603-608. 
Gauthier D. 1986. Morals by Agreement. Oxford: Clarendon.

Gneezy U., Rustichini A. 2000. Pay Enough or Don't Pay at All. Quarterly Journal of Economics. 115 (2): 791-810.

Greenberger S. 2003. Sick Day Abuses Focus of Fire Talks. Boston Globe. September 17. URL: https://www. highbeam.com/doc/1P2-7793689.html

Hayek F. A. 1948. Individualism and Economic Order. Chicago: University of Chicago Press.

Hirschman A. O. 1977. The Passions and the Interests: Political Arguments for Capitalism before Its Triumph. Princeton, NJ: Princeton University Press.

Hobbes T. 2005 [1651]. Leviathan. Edited by G. A. J. Rogers, K. Schuhmann. 2 vols. London: Continuum.

Holmes O. W., Jr. 1897. The Path of the Law. Harvard Law Review. 10 (457): 457-478.

Horace. 2004. Odes and Epodes. Edited and translated by N. Rudd. Cambridge, MA: Harvard University Press.

Hume D. 1964. David Hume: The Philosophical Works. Edited by T. H. Green, T. H. Grose. 4 vols. Darmstadt: Scientia Verlag Aalen. Reprint of the 1882 London ed.

Kahneman D. 1994. New Challenges to the Rationality Assumption. Journal of Institutional and Theoretical Economics. 150 (1): 18 -36.

Kahneman D., Tversky A. 2000. Choices, Values, and Frames. Princeton, NJ: Princeton University Press.

Machiavelli N. 1900 [1513]. Il Principe. Edited by Giuseppe Lisio. Florence: Sansoni.

Machiavelli N. 1984 [1513-1517]. Discorsisopra la PremaDeca Di Tito Livio. Milan: Rizzoli.

Mandeville B. 1924. The Fable of the Bees, or Private Vices, Publick Benefits. Oxford: Clarendon.

Mandeville B. 1988a. A Search into the Nature of Society. In: Kaye F.B. The Fable of the Bees. Indianapolis: Liberty Fund; 323-370.

Mandeville B. 1988b. A Vindication of the Book, from the Aspersions Contain'd in a Presentment of the Grand Jury of Middlesex, and An Abusive Letter to Lord C. In: Kaye F. B. (ed.) The Fable of the Bees. Indianapolis: Liberty Fund; 381-412.

Mill J. S. 1844. Essays on Some Unsettled Questions of Political Economy. London: Parker.

New York Times. Ban Greed? No: Harness It. Editorial. 1988. January 20.

Rousseau J.-J. 1984 [1762]. Of the Social Contract and Discourse on Political Economy. Translated by C. M. Sherover. New York: Harper and Row.

Sandel M. 2012. What Money Can't Buy: The Moral Limits of Markets. New York: Farrar, Straus and Giroux. 
Sandel M. 2013. Market Reasoning as Moral Reasoning: Why Economists Should Re-Engage with Political Philosophy. Journal of Economic Perspectives. 27: 121-140.

Satz D. 2010. Why Some Things Should Not Be for Sale: The Limits of Markets. Oxford: Oxford University Press.

Schumpeter J. 1950. The March into Socialism. American Economic Review. 40 (2): 446-456.

Smith A. 1976a [1776]. An Inquiry into the Nature and Causes of the Wealth of Nations. Edited by R. H. Campbell, A. S. Skinner. Oxford: Clarendon.

Smith A. 1976b [1759]. Theory of Moral Sentiments. Edited by D. D. Raphael, A. L. Macfie. Oxford: Clarendon.

Spinoza B. de. 1958. The Political Works. Edited and translated by A. G. Wernham. Oxford: Clarendon.

Strauss L. 1988. What Is Political Philosophy? Chicago: University of Chicago Press.

Thaler R., Sunstein C. 2008. Nudge: Improving Decisions about Health, Wealth, and Happiness. New Haven, Conn.: Yale University Press.

Warneken F., Tomasello M. 2008. Extrinsic Rewards Undermine Altruistic Tendencies in 20-Month-Olds. Developmental Psychology. 44 (6): 1785-1788.

Wrzesniewski A. et al. 2014. Multiple Types of Motives Don't Multiply the Motivation of West Point Cadets. Proceedings of the National Academy of Sciences of the United States of America. 111 (30): 1099010995. 


\section{Samuel Bowles}

\section{The Moral Economy: Why Good Incentives Are No Substitute for Good Citizens}

\author{
BOWLES, Samuel - \\ Research Professor, Director \\ of the Behavioral Sciences \\ Program, Santa Fe Institute. \\ Address: 1399 Hyde Park \\ $\mathrm{Rd}$, Santa Fe, New Mexico \\ 87501, USA.
}

Email: bowles@santafe.edu

\begin{abstract}
The Moral Economy is based in part on Castle Lectures given by Prof. Samuel Bowles at Yale University that resulted from his concerns about the cultural effects of markets and incentives over 30 years. In his book, Bowles focuses on a new policy paradigm, which proposes switching from Homo economicus to an approach considering people as they are. According to Bowles, the latter approach makes synergy between incentives and constraints as well as the conjunction of ethical and other-regarding motivations possible. The author argues that only market economies that do not ignore their cultural background and the goodness of people are able to work properly.
\end{abstract}

The Journal of Economic Sociology has published the first chapter, "The Problem with Homo Economicus," in which the author tries to convince readers that the principle of Homo economicus is not a good baseline assumption for policy-making and business management for at least two reasons. First, instrumental incentives do not guarantee good government. Second, a policy, which relies on self-interested and amoral humans, creates conditions for the dominancy of this human behavior model in the real world. The author addresses a wide variety of philosophical, political, and economic literature to construct his arguments. The book is very easy to read thanks to the vivid examples and attractive anecdotes it contains.

Keywords: moral economy; Homo economicus; instrumental motives; self-interest; goodness; knavery; markets.

\section{References}

Aristotle (1962) Nicomachean Ethics (trans. by Martin Ostwald), Indianapolis: Bobbs-Merrill.

Aristotle (1983) Sochineniya: V 4 t. V. 4 [Works. 4 vols. Vol. 4], Moscow: Mysl' (in Russian).

Aristotle (2006) On Rhetoric: A Theory of Civic Discourse (trans. by George A. Kennedy. Oxford: Oxford University Press.

Arrow K. J. (1971) Political and Economic Evaluation of Social Effects and Externalities. Frontiers of Quantitative Economics (ed. M. D. Intriligator), Amsterdam: North Holland, pp. 3-23.

Arrow K. J. (1972) Gifts and Exchanges. Philosophy and Public Affairs, vol. 1, no 4, pp. 343-362.

Arrow K. J., Hahn F. H. (1971) General Competitive Analysis. Advanced Textbooks in Economics, vol. 12, San Francisco: Holden-Day. 
Belkin D. (2002) Boston Firefighters Sick - or Tired of Working. Boston Globe, January 18. Available at: https://www.bostonglobe.com/ (accessed 20 September 2016).

Benner E. (2009) Machiavelli's Ethics, Princeton, NJ: Princeton University Press.

Bentham J. (1962) The Works of Jeremy Bentham, vol. 8 (ed. J. Bowring), New York: Russell and Russell.

Bentham J. (1998) Vvedenie v osnovaniya nravstvennosti i zakonodatel stva [An Introduction to the Principles of Morals and Legislation], Moscow: ROSSPEN (in Russian).

Bloomfield M. (1952) The Seven Deadly Sins, East Lansing: Michigan State University Press.

Boswell J. (1980 [1791]) Life of Johnson (ed. R. W. Chapman), Oxford: Oxford University Press.

Bowles S (2004) Microeconomics: Behavior, Institutions, and Evolution, Princeton, NJ: Princeton University Press.

Buchanan J. (1975) The Limits of Liberty, Chicago: University of Chicago Press.

Buchanan J. (1997) Konstitutsiya ekonomicheskoy politiki. Rashchet soglasiya. Granitsy svobody [The Constitution of Economic Policy. The Calculus of Consent.The Limits of Liberty], Moscow: Taurus Al'fa (in Russian).

Carroll L. (1991) Alisa v Strane chudes [Alice's Adventures in Wonderland], Moscow: Nauka (in Russian).

Carroll L. (2000) The Annotated Alice: The Definitive Edition of "Alice's Adventures in Wonderland" and "Through the Looking-Glass" by L. Carroll, New York: Norton.

Confucius (2000) Izrecheniya. Kniga pesen i gimnov [Aphorisms. The Book of Odes and Hymns], Moscow: AST (in Russian).

Confucius (2007) The Analects of Confucius (trans. B. Watson), New York: Columbia University Press.

Dumont L. (1977) From Mandeville to Marx: The Genesis and Triumph of Economic Ideology, Chicago: University of Chicago Press.

Durkheim E. (1967 [1902]) De la Division du Travail Social. Bibliothéque De Philosophie Contemporaine, Paris: Presses universitaires de France.

Edgeworth F. Y. (1881). Mathematical Psychics: An Essay on the Application of Mathematics to the Moral Sciences, London: Kegan Paul.

Gasiorowska A., Zaleskiewicz T., Wygrab S. (2012) Would You Do Something for Me? The Effects of Money Activation on Social Preferences and Social Behavior in Young Children. Journal of Economic Psychology, vol. 33, no 3, pp. 603-608.

Gauthier D. (1986) Morals by Agreement, Oxford: Clarendon.

Gneezy U., Rustichini A. (2000) Pay Enough or Don't Pay at All. Quarterly Journal of Economics, vol. 115, no 2, pp. 791-810. 
Greenberger S. (2003) Sick Day Abuses Focus of Fire Talks. Boston Globe, September 17. Available at: https://www.highbeam.com/doc/1P2-7793689.html (accessed 11 September 2016).

Hayek F. A. (1948) Individualism and Economic Order, Chicago: University of Chicago Press.

Hayek F. A. (2011) Individualizm i ekonomicheskiy poryadok [Individualism and Economic Order], Chelyabinsk: Sotsium (in Russian).

Hirschman A. O. (1977) The Passions and the Interests: Political Arguments for Capitalism before Its Triumph, Princeton, NJ: Princeton University Press.

Hobbes T. (1991) Sochineniya: V 2 t. V. 2 [Works. 2 vols. Vol. 2], Moscow: Mysl' (in Russian).

Hobbes T. (2005 [1651]) Leviathan (eds. G. A. J. Rogers, K. Schuhmann), 2 vols, London: Continuum.

Holmes O. W., Jr. (1897) The Path of the Law. Harvard Law Review, vol. 10, no 457, pp. 457-478.

Horace (2004) Odes and Epodes (ed. and trans. N. Rudd), Cambridge, MA: Harvard University Press.

Hume D. (1964) David Hume: The Philosophical Works (eds. T. H. Green, T. H. Grose), 4 vols, Darmstadt: Scientia Verlag Aalen. Reprint of the 1882 London ed.

Kahneman D. (1994) New Challenges to the Rationality Assumption. Journal of Institutional and Theoretical Economics, vol. 150, no 1, pp. 18-36.

Kahneman D., Tversky A. (2000) Choices, Values, and Frames, Princeton, NJ: Princeton University Press.

Machiavelli N. (1900 [1513]) Il Principe (ed. Giuseppe Lisio), Florence: Sansoni.

Machiavelli N. (1984 [1513-1517]) Discorsisopra la PremaDeca Di Tito Livio, Milan: Rizzoli.

Machiavelli N. (2004) Sochineniya istoricheskie i politicheskie. Sochineniya khudozhestvennye. Pis'ma [Works on History and Politics. Fiction. Letters], Moscow: AST (in Russian).

Mandeville B. (1924) The Fable of the Bees, or Private Vices, Publick Benefits, Oxford: Clarendon.

Mandeville B. (1974) Basnya o pchelakh [The Fable of the Bees], Moscow: Mysl' (in Russian).

Mandeville B. (1988a) A Search into the Nature of Society. The Fable of the Bees (ed. F. B. Kaye), Indianapolis: Liberty Fund, pp. 323-370.

Mandeville B. (1988b) A Vindication of the Book, from the Aspersions Contain'd in a Presentment of the Grand Jury of Middlesex, and An Abusive Letter to Lord C. The Fable of the Bees (ed. F. B. Kaye), Indianapolis: Liberty Fund, pp. 381-412.

Mill J. S. (1844) Essays on Some Unsettled Questions of Political Economy, London: Parker.

Mill J. S. (2007) Osnovy politicheskoy ekonomii s nekotorymi prilozheniyami $k$ obshchestvennoy filosofii [Backgrounds of Political Economy and Some Applications to Social Philosophy], Moscow: EKSMO (in Russian). 
New York Times (1988) Ban Greed? No: Harness It. Editorial. January 20.

Rousseau J.-J. (1969) Traktaty [Treatises], Moscow: Nauka (in Russian).

Rousseau J.-J. (1984 [1762]) Of the Social Contract and Discourse on Political Economy (trans. C. M. Sherover), New York: Harper and Row.

Sandel M. (2012) What Money Can't Buy: The Moral Limits of Markets, New York: Farrar, Straus and Giroux.

Sandel M. (2013) Market Reasoning as Moral Reasoning: Why Economists Should Re-Engage with Political Philosophy. Journal of Economic Perspectives, vol. 27, pp. 121-140.

Satz D. (2010) Why Some Things Should Not Be for Sale: The Limits of Markets, Oxford: Oxford University Press.

Schumpeter J. (1950) The March into Socialism. American Economic Review, vol. 40, no 2, pp. 446-456.

Smith A. (1976a [1776]) An Inquiry into the Nature and Causes of the Wealth of Nations (eds. R. H. Campbell, A. S. Skinner), Oxford: Clarendon.

Smith A. (1976b [1759]) Theory of Moral Sentiments (eds. D. D. Raphael, A. L. Macfie), Oxford: Clarendon.

Smith A. (1997) Teoriya nravstvennyh chuvstv [Theory of Moral Sentiments], Moscow: Respublika (in Russian).

Smith A. (2007) Issledovanie o prirode i prichinakh bogatstva narodov [An Inquiry into the Nature and Causes of the Wealth of Nations], Moscow: EKSMO (in Russian).

Spinoza B. de (1957) Izbrannye proizvedeniya: V 2 t. T. 2 [Selected Works. 2 vols. Vol. 2], Moscow: Gosudarstvennoe izdatel'stvo politicheskoy literatury (in Russian).

Spinoza B. de (1958) The Political Works (ed. and trans. A. G. Wernham), Oxford: Clarendon.

Strauss L. (1988) What Is Political Philosophy? Chicago: University of Chicago Press.

Subbotin A. L. (1986) Bernard Mandeville, Moscow: Mysl' (in Russian).

Takho-Godi A. A. (ed.) (1978) Antichnye ritoriki [Classical Rhetoric], Moscow: MSU Publising (in Russian).

Thaler R., Sunstein C. (2008) Nudge: Improving Decisions about Health, Wealth, and Happiness, New Haven, Conn.: Yale University Press.

Warneken F., Tomasello M. (2008) Extrinsic Rewards Undermine Altruistic Tendencies in 20-Month-Olds. Developmental Psychology, vol. 44, no 6, pp. 1785-1788. 
Wrzesniewski A., Schwartz B., Cong X., Kane M., Omar A., Kolditz T. (2014) Multiple Types of Motives Don't Multiply the Motivation of West Point Cadets. Proceedings of the National Academy of Sciences of the United States of America, vol. 111, no 30, pp. 10990-10995.

Received: September 5, 2016.

Citation: Bowles S. 2016. Moral'naya ekonomika: pochemu khoroshie stimuly ne zamenyat khoroshikh grazhdan [The Moral Economy. Why Good Incentives Are No Substitute for Good Citizens]. Journal of Economic Sociology = Ekonomicheskaya sotsiologiya, vol. 17, no 4, pp. 100-128. Available at: https://ecsoc.hse. $\mathrm{ru} / 2016-17-4 . h t m l$ (in Russian). 


\section{ДЕБЮТНЫЕ РАБОТЫ}

\section{М. В. Чернышёва}

\section{Благотворительность малого и среднего бизнеса в малом городе: эмпирический анализ ${ }^{1}$}

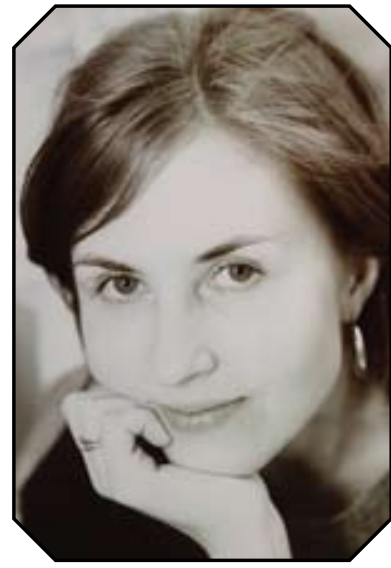

ЧЕРНЫШЁВА Марина Вячеславовна аспирант департамента социологии факультета социальных наук Национального исследовательского университета «Высшая школа экономики».

Адрес: 101000, Россия, г. Москва, ул. Мясницкая, д. 20.

Email: mchernysheva@ hse.ru
Данная работа представляет собой результат эмпирического исследования благотворительности малого и среднего бизнеса в российском малом городе. Под благотворительностью бизнеса в статье понимается несистематическое оказание бизнесом помощи нуждающимся. Цель работы - выявление мотивов и барьеров участия малого и среднего бизнеса в благотворительности. Для объяснения сущеествования и развития благотворительности малого и среднего бизнеса используются критическая тео-рия, теории солидарности, а также модели обмена привилегий на лояльность. Критическая теория интерпретирует консенсус между бизнесом и его стейкхолдерами через формирование идеологии, выгодной бизнесу. Благотворительность бизнеса рассматривается как средство построения положительного имиджа, приносящее выгоды для бизнеса в долгосрочной перспективе. Теории солидарности объясняют благотворительность сущуествованием норм «общинности», которым должен соответствовать предприниматель, будучи членом местного сообщества. В модели обмена привилегий на лояльность, основанной на идее патримониального господства (М. Вебер), благотворительность объясняется наличием ресурсных обменов между властью и местным бизнесом. Эмпирической базой исследования являются 21 полуструктурированное интервью с руководителями малого и среднего бизнеса и 13 интервью с руководителями некоммерческих, бюджетных организаций, с представителями власти, местными СМИ. Исследование было проведено в 2015-2016 г2. в одном из российских мальх городов путём двух выходов в поле. Установлено, что в рамках покрытого выборкой поля существование или отсутствие благотворительности бизнеса зависит от выстраивания баланса отношений между бизнесом, локальным сообществом и местными властями. Объёмы и устойчивость благотворительности отличаются в зависимости от того, какой из секторов оказывает влияние на благотворительность. Так, локальное сообщество в малом городе задаёт стабильный социальный порядок осуществления благотворительности, однако личная благотворительность невелика по масштабам. Наиболее же устойчивые и значимые благотворительные пожертвования возможны при запросах власти. Однако такие запросы осуществимы только при наличии ответных ресурсов бизнесу со стороны властей.

Ключевые слова: благотворительность бизнеса; малый и средний бизнес; критическая теория; солидарность; локальное сообщество; патримониальный авторитет.

1 Я искренне благодарна моему научному руководителю Кузиной Ольге Евгеньевне за открытость, помощь и ценные комментарии на всех этапах исследования. 


\section{Введение}

Корпоративная социальная ответственность и благотворительность бизнеса привлекают широкое внимание исследователей. Однако как в российских, так и в международных исследованиях внимание преимущественно обращено на мультинациональные компании и крупный бизнес, обладающий значительными ресурсами [Перегудов 2003; 2006; 2008; Благов, Литовченко, Иванова 2008; Благов, Соболев 2014; Snider, Hill, Martin 2003; Husted 2006; Jenkins 2006; Perrini, Russo, Tencati 2007; Spence 2007; Vo 2011; Baumann-Pauly, Scherer 2012]. Но в процессы благотворительности вовлекаются не только крупные компании; малый и средний бизнес также часто оказывает поддержку локальному сообществу. Агрегированно корпоративная социальная ответственность малого и среднего бизнеса вносит существенный вклад в поддержку местных сообществ [Vázquez-Carrasco, López-Pérez 2013]. Ocoбенно значимой такая поддержка оказывается в небольших городах и поселениях, где крупные предприятия часто не функционируют, а малый и средний бизнес является наиболее широко представленным, поэтому именно к нему обращается за поддержкой локальное сообщество [Besser 2012].

Вопрос социальной поддержки бизнесом локального сообщества особенно актуален для российских некрупных городов и поселений, где остро ощущается недостаток государственного финансирования социальной сферы, обусловленный низкой финансовой автономией поселений и нехваткой субсидий от вышестоящих бюджетов ${ }^{2}$. Несмотря на актуальность проблемы, благотворительность малого и среднего бизнеса является в России малоизученным направлением. Существующие исследования корпоративной социальной ответственности и благотворительности бизнеса рассматривают крупный бизнес или изучают бизнес в целом, не выделяя малый и средний в качестве отдельного эмпирического объекта [Чирикова et al. 2005; Чирикова 2012; Перегудов 2003; 2006; 2008; Благов, Литовченко, Иванова 2008; Благов, Соболев 2014 ]. Можно отметить лишь один российский проект, рассматривающий благотворительность малого бизнеса (см.: [Оберемко 2006; 2007]).

Актуальность темы требует проведения эмпирических исследований и понимания, почему малый и средний бизнес вовлекается в благотворительность. Однако для понимания недостаточно использовать модели, разработанные для исследования корпоративной социальной ответственности крупного бизнеса [Spence, Rutherfoord 2003; Perrini, Russo 2010]. Деятельность малого и среднего бизнеса сильно отличается от крупных фирм, причём дело не только в объёмах ресурсов, но и в качественных характеристиках бизнеса. Малый и средний бизнес сильно укоренены в местном сообществе. В таком бизнесе важна роль личности собственника, а также качество его взаимоотношений с местным сообществом. Малый и средний бизнес - это не «маленький крупный бизнес» [Tilley 2000].

Российские исследования малого бизнеса также показывают, что запрос на благотворительность бизнеса не только исходит от сообщества и связан не только с ценностями и предпочтениями бизнесмена, но также выводим из приоритетов местных властей [Оберемко 2006; 2007]. Причём часто запросы от властей носят вынужденный характер для бизнеса.

Актуальность исследования определила цель данной работы, то есть выявление мотивов, барьеров, форм участия малого и среднего бизнеса в благотворительности на территории, где бизнес осуществляет основную деятельность. Благотворительность малого и среднего бизнеса представляет собой деятельность, на становление и развитие которой влияют три сектора - бизнес, локальное сообщество и местные власти. В исследовании поэтому рассматривались две группы вопросов:

2 Только 6\% полученных поселением доходов остаётся внутри него; остальные средства направляются вышестоящим бюджетам, после чего поселение получает финансирование на социальную сферу через целевые программы [Князев Слепов 2012]. 
- отношения бизнеса с локальным сообществом: почему бизнес участвует или не участвует в поддержке локального сообщества? В каких формах оказывается поддержка? Что бизнес получает в ответ на благотворительность? Как влияют отказы бизнеса на взаимоотношения с местным сообществом?

- отношения бизнеса с местными властями: почему бизнес соглашается или не соглашается участвовать в благотворительности по запросам властей? Что бизнес получает и (или) ожидает получить в ответ на благотворительность по запросам властей? Как бизнесмены воспринимают отсутствие или наличие взаимодействия с властью?

Согласно А. Кэрроллу, корпоративная социальная ответственность бизнеса состоит из четырёх компонент - экономической, легальной, этической и филантропической [Carroll 1991]. Филантропическая же ответственность подразделяется на благотворительность и филантропию. Понятие «корпоративная благотворительность» определяется как краткосрочная помощь и облегчение социальных нужд; филантропию же рассматривают как системный подход, направленный на поиск долгосрочных решений и внедрение позитивных изменений в обществе [Leisinger 2007: 325]. В данной статье понятие «корпоративная благотворительность» используется как несистематическое оказание помощи нуждающимся сверх легальных требований к бизнесу. В России благотворительная деятельность часто является компенсацией недостатков государственной социальной политики [Кузина, Чернышева 2015]. Важно также отметить, что термин «корпоративный» неприменим для малого и среднего бизнеса (где нет корпораций), поэтому мы придерживаемся более нейтрального определения — «благотворительность бизнеса».

Под термином «локальное сообщество» подразумевается коллективная общность, члены которой проживают и осуществляют деятельность на единой территории [Parsons 1991].

Статья имеет следующую структуру: в теоретической части будет рассмотрен анализ специфики малого и среднего бизнеса, далее кратко даны описания подходов к объяснению благотворительной деятельности бизнеса, основанные на критической теории, теориях солидарности, модели обмена привилегий на лояльность ${ }^{3}$. После этого на основании материалов полевого исследования, проведённого в 2015-2016 гг. в одном из муниципальных образований РФ ${ }^{4}$, будут сделаны выводы о причинах существования или отсутствия благотворительности бизнеса.

\section{Специфика социальной ответственности малого и среднего бизнеса: международный опыт}

Прежде чем перейти к описанию теоретических подходов обоснования благотворительности, остановимся более подробно на качественных характеристиках малого и среднего бизнеса. В зарубежных исследованиях выделяется ряд характеристик малого и среднего бизнеса. Отмечается наличие значительного контроля, который имеет собственник над организацией. В отличие от крупных компаний, малый и средний бизнес управляется собственником и в организации отсутствует формальный управленческий персонал [Jenkins 2006; Russo, Tencati 2009]. Собственник является ключевой фигурой в вопросах взаимодействия бизнеса и локального сообщества [Quinn 1997]. Руководитель принимает все решения в отношении размещения ресурсов и, в частности, об оказании поддержки сообществу. Выделение средств на благотворительность часто обусловлено ценностными и психологическими установ-

3 Подробнее описание моделей благотворительности бизнеса см.: [Кузина, Чернышёва 2016], где сделан обзор моделей, разработанных классиками и современными исследователями по рассматриваемой тематике.

4

Название муниципального образования не уточняется из-за соображений соблюдения конфиденциальности. 
ками собственника [Jenkins 2006; Fernandez, Delgado, Garcia 2007; Spence 2007]. Сами собственники компаний в качестве основной причины осуществления корпоративной социальной ответственности называют этические и моральные соображения: социальная деятельность приносит собственникам чувство удовлетворения, ощущение, что сделано хорошее, нужное дело. Хотя также осознаются и долгосрочные экономические преимущества социальной деятельности, основные из которых — так называемые мягкие, к которым относится улучшение имиджа и репутации [Jenkins 2004; Vázquez-Carrasco, López-Pérez 2013].

Управление и коммуникация в некрупных компаниях осуществляются через личные контакты, что поддерживает атмосферу неформальности, личного доверия и открытого диалога с сотрудниками, локальным сообществом, клиентами и поставщиками [Murillo, Lozano 2006; Preuss, Perschke 2010]. Личное ежедневное общение со стейкхолдерами влияет на то, чтобы соблюдать этические принципы при отношении к ним [Spence, Habisch, Schmidpeter 2004; Lähdesmäki, Suutar 2012]. Так, внимание малого и среднего бизнеса чаще сконцентрировано на поддержке «внутренних» стейкхолдеров - местного сообщества и персонала [Jenkins 2006].

Сильная укоренённость малого и среднего бизнеса в локальном сообществе приводит к тому, что деятельность малых и средних организаций зависит от качества отношений собственника бизнеса со стейкхолдерами [Jenkins 2004]. Успех деятельности организаций связывается с легитимностью и одобрением малого и среднего бизнеса локальными стейкхолдерами. Местное сообщество регулирует деятельность бизнеса (в том числе социальную) нормами, ожиданиями, а также социальными санкциями [Lähdesmäki, Suutar 2012]. Бизнес поэтому вовлекается в социальную поддержку сообщества, несмотря на жёсткие ресурсные ограничения (финансовые, временные), необходимость выживания и одновременного решения большого количества задач [Spence 1999].

В малых населённых пунктах, где географическая и социальная близость высока, социальные санкции для малого и среднего бизнеса становятся ещё более ощутимы. Отказы бизнеса в благотворительной поддержке могут привести к потере личной репутации, а личная репутация бизнесмена в условиях тесных социальных связей влияет на экономическую деятельность всего предприятия. По мнению Т. Бессер, «в малых городах размер бизнеса менее важен в предсказании наличия благотворительной поддержки бизнеса, нежели ожидания со стороны локального сообщества» [Besser 2012: 78].

\section{Благотворительность бизнеса: частные интересы бизнеса, солидарность, обмен привилегий на лояльность или отношения силы?}

\section{Неоклассическая теория, теория стейкхолдеров}

Сторонники неоклассической экономической теории утверждают, что в том случае, если фирма действует в долгосрочной перспективе, максимизирует собственную полезность, платит налоги (то есть делает именно то, что организация умеет делать лучше всего), в выигрыше будут и все стейкхолдеры компании [Sundaram, Inkpen 2004]. Данное соображение известно по широко цитируемому утверждению М. Фридмана о том, что социальная ответственность бизнеса заключается в максимизации прибыли для акционеров [Friedman 1970]. В дальнейшем неоклассическая теория была дополнена. Помимо непосредственных акционеров компании, предлагалось включать в рассмотрение также широкий круг стейкхолдеров - работников, местные сообщества, власть. Введение дополнительных агентов обосновано в том случае, если учёт их интересов увеличивает прибыли организации в долгосрочной перспективе. Например, социальные инвестиции улучшают репутацию фирмы; организации привлекают более квалифицированных сотрудников. Такой подход в менеджменте называется теорией стейкхолдеров [Freeman 1984]. Теория стейкхолдеров сегодня активно используется при анализе корпоративной 
социальной ответственности в целом (Э. Гаррига и Д. Мелле относят данную теорию к инструментальным [Garriga, Melé 2004]), а также при анализе деятельности малого и среднего бизнеса в частности [Jenkins 2004; 2006; Spence 2007; Vázquez-Carrasco, López-Pérez 2013].

\section{Критическая теория}

Если в теории стейкхолдеров успешная деятельность бизнеса зависит от учёта интересов всех заинтересованных в деятельности компании сторон, то в критической теории корпоративная социальная ответственность и благотворительность бизнеса рассматриваются как идеологический инструмент конструирования видимости консенсуса между бизнесом и стейкхолдерами с целью получения долгосрочных выгод [Arnove 1980; Roelofs 2003; Rajak 2008; Prasad, Holzinger 2013]. Осуществляя вклад в общественные блага, корпорации заботятся об улучшении своего имиджа. Например, табачные компании тратят гораздо больше средств на продвижение своих филантропических инициатив, нежели на сами филантропические активности. Или же организации выстраивают имидж ответственной «зелёной» компании, рассказывая об экологичности своих товаров и упаковки. Тем самым улучшается имидж компании в глазах потребителей, государственных структур. Однако радикальных действий по повышению экологичности бизнес-процессов корпорации не осуществляют (феномен greenwashing зелёный камуфляж) [Prasad, Holzinger 2013]. Таким образом, критическая теория исходит из идеи конфликта интересов между классами в обществе, показывая, как компании при финансировании социальных благ влияют на экономические и иные предпочтения общества в собственных целях и интересах. Тем не менее, несмотря на свою привлекательность, критический анализ достаточно редко применяется при рассмотрении корпоративной социальной ответственности из-за сложности эмпирической проверки мнимости или реальности консенсуса.

\section{Теории солидарности}

В отличие от критической теории, объяснение благотворительности в рамках теорий солидарности предоставляет исследователю больше возможностей для эмпирического анализа. То, что в критической теории интерпретируется как идеология, используемая бизнесом для достижения своих частных интересов, в теориях солидарности объясняется как деятельность, способствующая ограничению частных интересов бизнеса с целью обеспечения жизнедеятельности локального сообщества. При рассмотрении деятельности малого и среднего бизнеса предприниматели в данных теориях выступают как члены локального сообщества, разделяющие существующие в нём нормы солидарности.

Бизнес, осуществляя благотворительную деятельность, ориентируется не только на свои частные интересы. В благотворительности бизнеса находит своё отражение логика солидарности. Как отмечает В. Ф. Чеснокова, согласно Ф. Тённису, общинные отношения (гемайншафт - нем. Gemeinschaft) основаны на логике домашних миров, соседства и дружбы и базируются на принципах солидарности [Чеснокова 2010]. Совместное бытие в общине порождает выработку социальной естественной воли - совместного решения, консенсуса, взаимопонимания в отношении норм и правил поведения членов общины. Такие отношения противостоят общественным отношениям (гезельшафт - нем. Gesellschaft), которым присуща рациональная, индивидуалистическая воля, ориентированная на достижение личных выгод.

Согласно О. Оберемко, желание предпринимателя оказывать благотворительную поддержку связано с его чувством идентичности с родным городом, а также с солидарностью с локальным сообществом в логике гемайншафт [Оберемко 2007]. В качестве непосредственного стимула к благотворительности О. Оберемко рассматривает необходимость реализации локальной идентичности бизнесменов, находящей выражение в активной свободной деятельности по отношению к местному сообществу. Оказывая 
личную благотворительность, бизнесмены действуют в логике «общинных» миров, принимая на себя «домашние» роли, ожидаемые от них локальным сообществом, например, такие роли, как «хороший хозяин», «отзывчивый сосед», «надёжный друг». В данной логике благотворительная деятельность распространяется не только на лично знакомых, но и на тех, кто ассоциируется с кругом «своих» Например, следуя «общинной» логике, предприниматель добровольно поддерживает школу, где учатся его дети. В данном случае он оказывает содействие не только своему ребёнку, но и всей школе; при этом собственник малого бизнеса не ждёт какой-то отдачи, благодарности и признания от своей благотворительности, поскольку помогает своему «близкому кругу».

В работах О. Оберемко благотворительность рассматривается как добровольная деятельность, реализуемая в рамках логики общинных миров, однако добровольность благотворительности в малом городе можно поставить под сомнение. Как и в логике общинных миров Ф. Тённиса, в рамках структурного функционализма речь идёт о существовании норм солидарности, однако в структурном функционализме подчёркивается принудительная внешняя сила, задающая определённый социальный порядок. Согласно Т. Парсонсу, общество рассматривается по аналогии с биологическим организмом, действия которого направлены на поддержание целостности и успешной адаптации к внешним неблагоприятным условиям [Parsons 1964]. Нормы солидарности поддерживают социальную интеграцию, целостность общественного организма. Солидарность же становится возможной потому, что нормы интернализированы в сознание людей и формируют определённые ожидания в отношении действий членов коллектива [Филиппов 2011]. Благодаря интернализированности социальных норм солидарности и социальный порядок благотворительности воспринимается как добровольный.

Однако обязательный характер благотворительности становится видимым в том случае, если рациональные интересы бизнеса вступают в конфликт с усвоенными нормами солидарности. Тогда во избежание социальных санкций [Parsons 1991] предприниматели начинают искать баланс взаимоотношений с локальным сообществом. Социальной санкцией для бизнесмена выступает угроза потери личной репутации в терминах «общинной» логики - предпринимателю необходимо быть хорошим человеком, другом, соседом. Бизнесмен старается не отказывать тем, кто приходит с просьбами, но помощь оказывается в небольших объёмах, посильных для бизнеса, как финансовых, так и нефинансовых (выделение материалов, осуществление небольшого ремонта). Отказы могут привести к потере личной репутации бизнесмена, что в условиях тесных социальных связей негативно влияет на экономическую деятельность всего предприятия.

\section{Обмен привилегий на лояльность и отношения силы}

Критическая теория объясняет вовлечение в благотворительность через заинтересованность бизнеса в частных достижениях. Теории солидарности объясняют существование благотворительности через функционирование норм солидарности, имеющих обязательный характер для бизнесменов и не подлежащих сомнению. Однако ни критическая теория, ни теории солидарности не включают в рассмотрение влияние третьего игрока — местную власть.

Для объяснения функционирования института благотворительности, основанного на взаимодействии бизнеса и власти, мы обратимся к пониманию власти, силы и господства М. Вебером. Он понимает власть как «вероятность того, что один актор внутри социальных отношений осуществляет свою волю, несмотря на сопротивление других акторов, независимо от оснований, на которые эта вероятность опирается» [Weber 1978: 53]. Такими основаниями являются сила и господство. Для Вебера власть, основанная на силе, рычагах принуждения, нелегитимна и, следовательно, неустойчива, в то время как разные типы авторитетов основаны на вере в легитимность господства, что ведёт к «добровольности» подчинения и стабильности власти. 
Вебер выделяет три типа господства - харизматический, традиционный и рационально-легальный, каждый из которых имеет разные основания легитимности. Для харизматического типа господства легитимность основана на вере в исключительность правителя и его миссию. Харизматический лидер - это человек, обладающий экстраординарными качествами, способный воодушевить и повести за собой последователей. Легитимность рационально-легального типа господства основана на вере в установленные формальные правила.

В традиционном типе господства авторитет власти базируется на том, что взаимоотношения между правителем и его администрацией строятся на основании обмена привилегий на лояльность: лояльная администрация получает от правителя различные виды привилегий [Weber 1978: 1010_1012]. По Веберу, данный тип господства (как и другие типы) является идеально-типической конструкцией и присущ традиционному типу, но его черты также могут быть обнаружены и в современных обществах. Мы считаем, что именно понятие «патримониальный авторитет» необходимо использовать для объяснения наличия или отсутствия благотворительности (см. подробнее: [Кузина, Чернышёва 2016]).

Логику патримониального господства можно применить к взаимоотношениям власти и бизнеса при осуществлении благотворительности в России (различая и не отождествляя термины «правитель» и «власть», «администрация» и «бизнес»). В данной логике благотворительная деятельность бизнеса объясняется через взаимоотношения между бизнесом и государством, основанные на обмене привилегий на лояльность. Бизнес получает от местных властей различные виды привилегий в обмен на благотворительные отчисления, демонстрирующие лояльность бизнеса власти. За проявленную лояльность власти поощряют бизнес отсутствием преследования и необходимыми ресурсами [Кузина, Чернышёва 2016]. Наличие обменов формирует лояльность бизнеса и поддерживает легитимность власти. Важно подчеркнуть, что для бизнеса речь идёт не о рациональной оценке баланса выгод и издержек отношений; в этом случае действует логика лояльности.

Очевидно, что взаимодействие бизнеса с властью, основанное на патримониальной системе обменов, имеет много недостатков. В частности, устойчивость бизнеса находится в сильной зависимости от установления личных взаимоотношений с местными властями. Риски особенно возрастают при смене власти. Например, объём благотворительных отчислений бизнеса будет увеличен новой властью или же для него закроют возможность получения необходимых ресурсов через обращение к административному ресурсу. И здесь для исследователя возникает закономерный вопрос: насколько устойчива патримониальная система «благотворительности» в России, при том что такая система обладает значительными недостатками для бизнеса и может поставить бизнес на грань выживания?

\section{Методология исследования}

В статье благотворительная деятельность малого бизнеса анализируется на материалах полевого исследования, проведённого автором статьи в 2015-2016 гг. в одном из муниципальных образований Краснодарского края - в городском поселении численностью 50 тыс. чел. Для получения информации использовалась качественная методология, сбор данных осуществлялся с помощью проведения полуструктурированных интервью по разработанному заранее гайду.

Часто исследования, посвящённые корпоративной благотворительности, социальной ответственности бизнеса, базируются на проведении глубинных полуструктурированных интервью. Это относится как к российским исследованиям [Перегудов 2003; Чирикова et al. 2005; Чирикова 2012; Оберемко 2006; 2007], так и к зарубежным работам [Taneja, Taneja, Gupta 2011]. Использование метода интервью обосновано также при анализе властных отношений и локальных сообществ малых городов [Чирикова, Ледяев, Сельцер 2014; Чирикова, Ледяев 2015]. Метод интервью позволяет получить информацию по 
заданному исследователем вопросу (в отличие, например, от анализа документов), а также даёт возможность выявить глубинные смыслы, которые вкладывают респонденты в исследуемые предметы [Штейнберг 2014].

\section{Обоснование выбора объекта исследования}

Выбор эмпирического объекта исследования был обусловлен следующими параметрами: экономически развитый район; распространённость в районе видов экономической активности, в которых широко представлен малый и средний бизнес.

Основными видами экономической активности в Краснодарском крае являются следующие: оптовая, розничная торговля и ремонт $(17,9 \%)$; транспорт и связь $(14,6 \%)$; строительство $(14,5 \%)$; обрабатывающие производства $(12,4 \%)$; сельское хозяйство (10,2\%) [Краснодарстат 2016]. В Краснодарском крае не являются основными сферы, в которых преобладает крупный бизнес, — например, тяжёлая металлургия, добыча и обработка природных ресурсов и проч. Край занимает пятое место в рейтинге по валовому региональному продукту (ВРП), пропуская вперёд Москву, Ханты-Мансийский автономный округ (добыча нефти), Московскую область и Санкт-Петербург [Федеральная служба... 2016], что говорит о высоком экономическом развитии района.

Дополнительным критерием в пользу выбора Краснодарского края являлось его лидерство в рейтинге по уровню коррупции среди регионов РФ. Так, по данным отчётов Ассоциации адвокатов России за права человека, в 2013-2015 гг. край занимал пятое — третье места в рейтинге уровня коррупции в субъектах РФ [Ассоциация адвокатов... 2014; 2015]. Было выдвинуто предположение: если в крае высок уровень коррупции, то, следовательно, отношения бизнеса и власти характеризуются высокой степенью неформальности, в том числе при построении благотворительности.

Основными критериями выбора конкретного района и городского поселения в качестве эмпирического объекта изучения являлись наличие устойчиво функционирующего, диверсифицированного малого и среднего бизнеса, а также недавняя смена власти в районе. Рассмотрение муниципалитета с недавней сменой власти давало возможность ответить на поставленные вопросы исследования: каким образом выстраиваются отношения между бизнесом и новой властью? Как эти взаимоотношения влияют на благотворительные пожертвования бизнесменов? Как бизнесмены воспринимают отсутствие или наличие взаимодействий с властью? За три года до проведения исследования предыдущий глава района был смещён досрочно. Три года работы власти нового главы - это срок, по которому уже можно судить о результатах его деятельности.

Согласно данным официальной статистики, в 2013-2014 гг. в районе наблюдалась стабильность деятельности малого бизнеса, количество предприятий в 2014 г. осталось практически неизменным по сравнению с предыдущим годом (98\% к предыдущему году). В 2014 г. численность данного типа бизнеса составила более 5000 субъектов. Средний бизнес представлен в районе уже не так широко: в 2014 г. на территории района функционировали восемь предприятий (по сравнению с девятью в 2013 г.).

Малый бизнес района участвует в различных видах экономической деятельности. Основным направлением как среди юридических лиц, так и среди индивидуальных предпринимателей является оптовая и розничная торговля, где индивидуальных предпринимателей (ИП) 55\%, а юридических лиц (юр. лицо) - 34,3\%. Юридические лица широко представлены в строительстве $(17,7 \%)$, в обрабатывающем производстве (14\%). Индивидуальные предприниматели - в сфере «транспорт и связь» (13\%). Как индивидуальные предприниматели, так и юридические лица занимаются предоставлением услуг, операциями с недвижимостью (ИП - 7\%, юр. лица - 10,9\%). Прочие виды экономической деятельности 
составили 16\% для ИП и $17 \%$ для юр. лиц. Средний бизнес представлен в таких видах деятельности, как обрабатывающие производства, строительство и иные 5 .

\section{Сбор и анализ данных}

В рамках полевых экспедиций были проведены 34 интервью с разными группами респондентов. Средняя продолжительность интервью - 45 мин. Были осуществлены два выхода в поле с промежутком восемь месяцев; общая длительность нахождения в поле составила три недели. Первый этап исследования являлся пилотным; второй выход в поле был обусловлен необходимостью насыщения полученных на первом этапе категорий. Отбор респондентов заканчивался при насыщении выявленных категорий анализа.

По просьбам респондентов многие беседы проводились без записи на диктофон. По мнению российских исследователей корпоративной благотворительности, одним из показателей достоверности полученной информации является раскрытие ситуаций, в которых интервьюируемый описывает нелегитимные практики, «в которых он предстаёт в не самом выгодном свете» [Чирикова et al. 2005: 5]. Именно такие практики описывались респондентами без включения диктофона. Тем не менее после проведения интервью беседа и полевые заметки тщательно записывались в полевой дневник.

Респонденты отбирались построением целевой выборки методом снежного кома [Ильин 2006]. Основными критериями отбора бизнесменов являлись следующие: осуществление бизнесом благотворительной деятельности а также принадлежность к малому и среднему бизнесу. Первоначально респонденты были рекомендованы тремя ключевыми информантами - благочинным района, руководителем торгово-промышленной палаты, а также одним из наиболее влиятельных в поселении бизнесменов, не являющимся членом торгово-промышленной палаты. Самый первый вход в поле был обеспечен знакомством с благочинным района.

Были опрошены руководители малого и среднего бизнеса из разных отраслей экономики (строительство, обрабатывающие производства, торговля, услуги, сельское хозяйство). С представителями бизнеса были проведены 21 интервью (см. таблицу П1 в приложении). Для соблюдения требования гетерогенности выбор объектов исследования корректировался в соответствии с данными официальной статистики распределения малого и среднего бизнеса по видам экономической деятельности в рассматриваемом районе.

Основными критериями отбора микропредприятий, малого и среднего бизнеса являлись официальные критерии, принятые в России до 2015 г.: величина дохода и численность персонала. Численность персонала для микропредприятий составляет до 15 чел., малого бизнеса - до 100 чел., среднего бизнеса — до 250 чел. [О развитии малого и среднего предпринимательства... 2007]. Величина дохода для микропредприятий составляет до 60 млн руб., малого бизнеса — до 400 млн руб., среднего бизнеса до 1 млрд руб. [О предельных значениях... 2013] ${ }^{6}$. Категория субъектов предпринимательства определялась по наибольшему значению одного из указанных показателей.

5 Данные официальной статистики по району были переданы исследователю на электронном носителе работниками администрации поселения.

6 Постановлением Правительства РФ от 13 июля 2015 г. № 702 (см.: [О предельных значениях... 2015]) критерии отнесения к малому и среднему бизнесу были изменены, величина дохода была увеличена вдвое. Тем не менее, поскольку в наличии у исследователя была статистика распределения бизнеса по видам экономической активности только за 2014 г. (к моменту первого входа в поле статистика за 2015 г. находилась в состоянии прогноза), использовались критерии 2014 г. 
Для повышения достоверности полученной от бизнеса информации использовался принцип триангуляции источников [Ильин 2006]. Помимо бизнесменов, опрашивались респонденты, обладающие информацией о благотворительной деятельности бизнеса рассматриваемого городского поселения. Были проведены 13 интервью с руководителями некоммерческих организаций, с представителями бюджетных организаций и власти, а также местных $\mathrm{CM}^{7}$. Респонденты являлись либо реципиентами помощи, либо экспертами по рассматриваемым вопросам. Например, не всегда бизнес открыто высказывался о наличии практик взаимодействия с властями, однако в малом городе такая информация на виду, интервью с разными группами респондентов давали возможность составить более объективную картину.

После проведения первого полевого этапа исследования интервью были транскрибированы, проведены процедуры кодирования, написан первый вариант отчёта. В отчёте были выделены основные категории и субкатегории анализа, определены вопросы, оставшиеся необъяснёнными. По результатам первого полевого выхода был подготовлен новый вариант путеводителя интервью. Интервью анализировались с помощью программного обеспечения NVivo (основные коды см. в приложении, таблица П2).

\section{Результаты анализа}

В рамках проведённого анализа мы обнаружили разные объяснительные логики существования благотворительности малого и среднего бизнеса в малом городе. В логике критического анализа организации преследуют свои частные интересы, выстраивая через благотворительность положительный имидж компании. Однако в случае малого города эффективность стратегии построения имиджа ответственного бизнеса сомнительна: в условиях тесных социальных связей реальная информация о предприятиях становится известной всему сообществу. В рамках теорий солидарности бизнес вовлекается в благотворительность, так как предприниматели чувствуют свою принадлежность локальному сообществу. Подтверждение данной логики мы находим как в анализе международного опыта, так и в российском малом городе. В логике патримониального авторитета благотворительность бизнеса существует в силу установленных с властями взаимоотношений обмена. Но если власти не выделяют необходимые для бизнеса ресурсы, бизнес отказывает властям в «моральном праве» обращаться за социальными отчислениями. Ниже мы приведём иллюстрации для каждой из рассмотренных логик.

\section{Благотворительность: достижение частных интересов бизнеса}

Проиллюстрируем применение идей критической теории для объяснения благотворительности бизнеса. В рассматриваемом городском поселении функционируют предприятия, оказывающие благотворительную поддержку по просьбам некоммерческих и бюджетных организаций поселения, собственники которых высказывали крайне негативное отношение к запросам о помощи и к самим реципиентам помощи. Например, руководители одного из предприятий называли просителей «попрошайками». Такое отношение к реципиентам помощи при оказании поддержки говорит о заинтересованном или вынужденном характере оказываемой поддержки.

Бывает, что отказываем, мы что, здесь - «Красный Крест»? Я вообще не понимаю, почему этим «попрошайкам» надо идти к бизнесу, унижаться? Неужели администрация не может нагнуть свои полугосударственнье предприятия? Есть у нас здесь такой карьер... (бизнес, производство, собственник).

Были проведены интервью с тремя представителями администрации - главой города и двумя сотрудниками отдела экономического развития, - с депутатом Законодательного собрания, руководителем и заместителем руководителя торгово-промышленной палаты, директорами общества ветеранов, общества инвалидов, школы, двух спортивных школ, музея, местной газеты. 
Несмотря на негативное отношение к самим просителям, компании необходима ответная реакция реципиентов. Так, благодарственные письма и грамоты вывешиваются на стенах в офисе, на сайте одной из организаций в графе «Отзывы» в первых строках размещены благодарности. Одним из таких отзывов на сайте является история пенсионерки (назовём её М. И. Ивановой), которая сделала заказ организации на бетонирование подъезда к гаражу мужа:

Обратились в компанию $[X]^{8}$ сделать подъезд к гаражу. Приехали ребята со всем оборудованием, залили не только подъезд, но и дорожки. Случайно узнали, что мой муж ветеран войны, и не стали брать деньги. Мьл очень благодарны Вашей организачии. Большое Вам спасибо!

Случайно узнав, что муж пенсионерки ветеран, рабочие не только перевыполнили заказ - залили дополнительные дорожки у дома, но и не взяли оплаты за все оказанные работы (информация о согласованности данного решения рабочими с менеджментом, а также о реакции менеджмента не уточняется). В целом истинность таких отзывов остаётся под вопросом, однако их размещение на сайте первой строкой свидетельствует о рассмотрении благотворительности в качестве инструмента для формирования положительного имиджа.

Данные примеры косвенно подтверждают критическую теорию, полагающую благотворительность инструментом построения имиджа организации. Рассмотренные предприятия имеют сформированный негативный имидж в поселении. Респонденты характеризовали их в таких терминах, как «беспринципные», «коррумпированные». Однако в условиях, когда практики ответственного поведения бизнеса ещё не оказывают существенного влияния на покупательскую способность населения, положительный имидж создаётся бизнесом не столько для потребителей, сколько для власти как основного стейкхолдера бизнеса [Кузина, Чернышёва 2016].

\section{Благотворительность: построение отношений между властью и бизнесом}

\section{Обмен привилегий на лояльность}

В рассматриваемом городском поселении как руководители бизнеса, так и респонденты из других опрошенных групп говорили о снижении (или о полном отсутствии) безвозмездного финансирования социальных проектов по запросам администрации. Отмечалось, что новый глава района не захотел выстраивать отношения с местным малым и средним бизнесом, при том что именно он обладает значительной властью и распоряжается всеми бюджетными ресурсами.

Так, респонденты в качестве одной из причин отсутствия «благотворительных» отчислений бизнеса отмечали отсутствие доступа к бюджетным ресурсам. При смене власти и после прихода нового главы региона доступ к административному ресурсу для местного бизнеса закрылся, в распределении бюджетных заказов и земель участвовали приближенные к власти - «свои» — фирмы. Значимая часть таких организаций состояла из фирм региона, из которого пришёл руководитель. Переориентация властей на «своих» и отсутствие привилегий для местного бизнеса приводит к отказу предпринимателей в «моральном праве» администрации обращаться к бизнесу с социальными запросами:

Какие-то дружжественные связи (Здесь и далее выделено мною. - М. Ч.), всё зависит от власти, кто принимает решение, тот, кто распоряжается этими деньгами, - это только первое лицо, оно не контактирует, может, с непосредственным процессом, но все эти цепочки видны, все они тянутся (бизнес, производство, собственник);

8 Завод по производству бетона. 
Нет, никаких взаимоотношений с администрацией такого рода нет, всё это делают фирмы при бюджете, у них есть объёмы работ, пускай они и помогают, всё держится на откатах (бизнес, строительство, собственник);

Никто не может что-то требовать, какой-то помощи, когда вот так все закупки проводятся. Всегда выигрывают только «свои»... (бизнес, производство, собственник).

Для того чтобы ограничить участие «чужих» в тендерных закупках, используется система административных барьеров - приглашение на тендерные закупки подставных лиц, формирование тендерных заданий для допуска в конкурсе (расшифровку которых знают только «посвящённые») и проч.:

Ой, ну, вы что, не знаете? Выставляется тендер, приглашаются подставные люди на тендер, подыгрывают... Понимаете, главное - желание, остальное - не преграда (бизнес, производство, собственник);

При прошлом главе какие-то объекты ещеё делал, сейчас я не делаю, потому что здесь стоит плотный заслон. Я работаю в шести районах, здесь я не работаю; это район один такой, по муниципальному бюджету работать невозможно, блок по 70 листов, всё, тема закрыта (бизнес, производство, собственник).

Помимо недопуска бизнеса для участия в конкурсах, отмечаются также многочисленные административные барьеры для него, не связанные с распределением бюджетного финансирования. Такие барьеры возникают при необходимости подключения к коммуникациям (электричество, газ), переведения участков земли из одного назначения в другое (например, стоянку у рынка нужно перевести в разряд торговых площадок), оформления документации. Подобные процедуры требуют длительного оформления, сложных бюрократических согласований. Если бизнес хочет ускорить или упростить процедуры, нельзя обойтись без взятки. Отсутствие помощи администрации в решении насущных для бизнеса вопросов сказывается не лучшим образом на благотворительной деятельности бизнеса, ведущейся по запросам властей:

Мелкие вопросы, это всё не через тендеры... Там очень много мелких вопросов, и мои ребята, некоторые, вот... Решил вопрос - как решил... Ну, вот так, надо же жить дальше. Я год оформляю свои земли, с 92-го года нахожусь в собственности... То одно, то другое... Нет коррупционной составляющей... Настолько сильна система бюрократическая, что невозможнно (бизнес, производство, собственник).

По мнению опрошенных предпринимателей, власти должны идти прежде всего навстречу местному бизнесу, то есть предприниматели ожидают «взаимности» со стороны властей. Такую точку зрения преимущественно высказывали предприниматели из производственной сферы и строительства. «Моральное» право осуществлять запросы о благотворительной помощи местному бизнесу зависит от выделения ресурсов, связанных с Федеральным законом «О контрактной системе в сфере закупок...» (№ 44-Ф3), местный бизнес ждёт включения в неформальные, серые схемы. Важнейшим ресурсом для бизнеса являются земля и заказы. Также бизнес ожидает, что власти будут способствовать упрощению процессов, не связанных с конкурсными закупками, но оказывающими непосредственное влияние на повседневную экономическую деятельность бизнеса. В том случае, если администрация идёт бизнесу навстречу в необходимых для бизнеса вопросах, предприниматели готовы к тому, что и власти «вправе требовать» социальные отчисления: 
Я считаю, что администрация должна нам, строителям, предложить эти объёмы по строительству тротуаров, дорог, ремонту крыш... То есть долюнны собрать нас, сказать: ребята, вот есть такие-то объёмы, кто из вас выбирает? Тогда администрация вправе попросить нас, потребовать от нас взаимности (бизнес, строительство, собственник).

Если же бизнес не получает поддержки, то это приводит к потере патримониальной легитимности властей, а следовательно, предприниматели всё чаще отказываются участвовать в благотворительных проектах.

Другая ситуация, город небольшой, каждый хочет ухватить кусок пожирнее, а уже кто-то за это держится, конкуренция, подковёрная борьба, козни, если администрация не оказывает защиту и помощь предпринимателю, стараясь защитить предпринимателей, как человек будет относиться к органам власти?(некоммерческая организация, президент);

А нынешний глава - хам, с ним ни о чём не договоришься (бизнес, производство, собственник).

Описанная выше ситуация показывает, как отсутствие взаимодействия власти с местным бизнесом, отсутствие отношений обмена привилегий на лояльность влекут за собой потерю легитимности в глазах местного малого и среднего бизнеса и его отказ от участия в благотворительности по запросам администрации.

\section{Формализация отношений власти и бизнеса}

Отношениям новой власти с местным бизнесом также не способствовало стремление государства к формированию институтов рационально-легального типа господства, то есть к регулированию отношений между бизнесом и властью с помощью формальных правил. Одним из таких шагов государства стала антикоррупционная политика, усиление проверок администрации со стороны прокуратуры района.

Деятельность нового главы из-за нецелевого использования бюджетных средств стала вызывать активный интерес проверяющих служб. Основное внимание было сфокусировано вокруг функционирования Федерального закона № 44-Ф3 [О контрактной системе... 2013]. Закономерно, что внимание проверяющих инстанций привлекали и «благотворительные» запросы властей, так как на социальные проекты выделяются бюджетные средства. В интервью отмечалось, что там, где присутствует бюджетное финансирование объектов, а следовательно, работает закон № 44-Ф3, средства бизнеса стараются не привлекать, так как такие проекты вызывают внимание проверяющих служб:

Когда там задействованы бюджетные деньги, безусловно, бизнес стараются не привлекать по той причине, что там есть прокуроры... Потому что потом сложно разобраться, где там какие источники финансирования - где бюджетные деньги, а где какие (некоммерческая организация, директор);

«У нас прокуратура какая-то очень агрессивная. Такие запросы очень чреваты потом походом в прокуратуру (работник районной администрации).

Антикоррупционная политика в районе также даёт возможность бизнесменам активно реагировать на нежелательные просьбы со стороны администрации и вне действия закона № 44-Ф3. Например, при запросах администрации к предпринимателям об ограждении их строительных площадок (хотя это не 
было согласовано с бизнесом ранее) один из бизнесменов записал обращение администрации к предпринимателям на телефон и подал заявление в полицию.

Любой звонок от меня предпринимателю можно расценить как факт коррупции. Ну, представьте, вы предприниматель, я звоню: «Дай 100 тысяч рублей, я хочу детскую площадку поставить». Вы как вменяемая, может, поймёте, а другой, который, может быть, невменяемый, он скажет: "Я сейчас вот это записал, я сейчас эту запись отнесу в прокуратуру». Как было на прошлой неделе, вопрос по оформлению строительных площяадок. Мне по закону должны быть ограждение и строительный паспорт, и город собрал этих наших строителей: ну, приведёте в соответствие, просто ограждение и паспорт. И один товарищ записал этот разговор и сразу же написал заявление в полицию. Ну, вроде бы зам. главы города на месте пока ещё. Тут же не угадаешь, на кого нарвёшься. Да и с одних и тех же, которые вменяемые... Не будешь к одним и тем же обращаться. Потому что нереально (работник районной администрации).

Для того чтобы бизнес соглашался на запросы администрации о благотворительной поддержке, такие запросы власти должны быть легитимными. Одним из оснований легитимности власти являются патримониальные обмены между бизнесом и властью, «взаимность». При отсутствии легитимности власти существует риск раскрытия бизнесом информации о неформальных запросах власти. Это приводит к тому, что в условиях усиления проверок со стороны прокуратуры для власти безопаснее поддерживать систему обменов с уже проверенными «своими» людьми, а не выстраивать отношения с новым бизнесом.

В условиях усиления прокурорских проверок администрация выставляет требование формализации благотворительных отчислений бизнеса. Однако для малого и среднего бизнеса осуществление благотворительности возможно только в неформальном поле. Для того чтобы проводить благотворительность формально, бизнесу необходимо показывать прибыль, а на это бизнес не готов пойти. Вновь формализация отношений между бизнесом и властью ведёт к уменьшению количества запросов со стороны администрации и сокращению помощи:

Или вот нужно помочь отремонтировать садик... Это всё формально, сегодня нельзя неформально. Мы требуем, и глава требует, чтобы всё это проходило документально, чтобы не было на мне, как это было... Последний случай: задержали чиновника, брал на благое дело, задержали за 500 тысс. рублей, а он просил эти деньги на ремонт скважин для поселения. Сколько глава говорил, пускай счёт оплатит, потом помогает... ФСБ, Следственный комитет задержали. Сегодня возбудили дело уголовное. Нехорошее свидетельство, это член партии «Единая Россия»... (депутат Законодательного собрания);

Интервьюер. Это же можно провести документально, что бизнесмен помог?

Респондент. Сейчас у бизнеса такая ситуащия, знаете тоже...Нет денег лишних, мало у кого эти деньги личние есть.

(Из интервью с работником районной администрации)

Одной из точек зрения бизнеса при вопросе: «Обращается ли администрация с социальными запросами?», — оказалась позиция, выражаемая формулой: «Задача бизнеса — платить налоги». Такую точку зрения высказывали предприниматели, занимающиеся торговлей и услугами, то есть сфер бизнеса, которые в меньшей степени зависят от ресурсов администрации. Потенциальное обращение админи- 
страции с запросами после того, как бизнес уплатил значимую сумму налогов, расценивается предпринимателями негативно:

Администрации мы налоги платим, я считаю, что дополнительные сборы - это неправильно (бизнес, услуги, собственник);

Если бы все платили налоги так, как мы, в буквальном смысле слова, то и социальная жизнь в любом населённом пункте, в городе, была бы лучше. Задача бизнеса - это платить налоги. Задача администрации - это правильно распределить эти суммы полученные (бизнес, торговля, собственник).

Респонденты из всех рассматриваемых сфер бизнеса отмечали упрощение проверок, которые в настоящее время являются плановыми, а следовательно, к ним можно подготовиться заранее. В целом бизнес старается соблюдать заявленные администрацией требования, оплачивает значимые суммы налогов, соблюдает требования в отношении благоустройства территорий:

Сейчас все эти возможные проверки и всё прочее - они плановые (бизнес, услуги, собственник);

До сегодняшнего дня, положа руку на сердие, препонов пока никаких, довольно-таки... очень доброжелательное и со стороны силовиков, и этих... Ну, то есть мы живём все постепенно, нас не трогают, мы налоги платим (бизнес, строительство, собственник);

По итогам прошлого года мы только 1,5 млн заплатили налогов (бизнес, услуги, собственник).

Власти, всегда имея возможность применить административные рычаги («всегда найдут, к чему придраться»), большей части бизнеса предпочитают «не помогать и не мешать». Если требования бизнесом не выполняются в полной мере (например, недоплачиваются налоги), в условиях сложной экономической ситуации властям выгоднее не оказывать давление на предпринимателя. В противном случае предприятие закроется, перестанет платить налоги, проверяющим службам будет некого проверять, люди лишатся рабочих мест и проч.:

Проверки как бы есть... Ну, не такие уж и сильные, как раньше. Сейчас боятся проверять, потому что... Ну, я и так устал, не надо меня трогать, я же ну... Вас-то не будет, вашей организации... Кого же вы будете проверять? Я ж⿻ закроюсь тогда... Откуда же вы деньги будете получать? (бизнес, торговля, собственник).

Таким образом, движение в сторону формализации взаимодействий между бизнесом и властью приводит к негативному отношению бизнеса к неформальным запросам со стороны властей и отсутствию благотворительности бизнеса.

\section{Отношения силы}

В условиях, когда с местным бизнесом не выстроены отношения взаимности, власти необходимы ресурсы, в этом случае взаимодействие с бизнесом выстраивается через административное давление. Власть требует от бизнеса вложений, причём компенсации не предполагается [Чирикова 2012]. Отношения силы возможны при наличии рычагов давления на бизнес в случае отказа от социальных отчислений. 
Среди рычагов давления на бизнес респонденты отмечали инициирование властью проверок органами санэпидемнадзора, прокуратуры, а также экологами, пожарными и др. Например, в регионе есть предписание губернатора о поддержании порядка и чистоты на территориях предприятий. Еженедельно по улицам осуществляются рейды и проверки. Несоблюдение заявленных требований даёт возможность пригласить проверяющие службы - например, экологов, которые выставят штрафы. К организациям, не соблюдающим заявленные требования, обращаются за «благотворительной помощью»:

Хотя сегодня ужесточилась борьба с коррупџией, всегда можно подключить санэпидем, пожарных, экологов (некоммерческая организация, директор);

Те же пожарные найдут к чему придраться... Хотели отказать им, но сразу инициируются проверки: ой, бетон! Ой, голова болит!.. Хотя мьл находимся в промышленной зоне, здесь много таких организащий (бизнес, производство, собственник);

А там штрафы немаленькие, для ИП это 10 mыс., для ООО - 200 тыс. (бизнес, производство, собственник).

Как следствие, бизнес боится отказать власти и другим государственным службам, что ведёт к «вынужденной благотворительности»:

Всегда найдут к чему придраться — это экология, пьль... Вот поэтому отказать и нельзя (бизнес, производство, собственник).

В случае отказа бизнесу не только грозит приглашение проверяющих инстанций, но ему также закрывают доступ к необходимым ресурсам, так как портятся отношения с местными властными структурами, осуществляющими запросы на благотворительность. Например, в случае отказа оплатить лечение ребёнка, семья которого обратилась за помощью в администрацию, чиновники перестают приглашать бизнес к участию в обсуждениях инвестиционных проектов, реализуемых в районе. Ранее участие в таких встречах способствовало знакомству с потенциальными для бизнеса клиентами.

При административном давлении компенсация «благотворительных» пожертвований бизнесу не предусматривается, но даруется возможность ведения бизнеса на территории района без выполнения в полном объёме предписанных проверками требований. Бизнес предпочитает в условиях внешнего давления оплачивать «благотворительные» запросы, а не выполнять требования проверяющих инстанций в полном объёме - например, порядок и чистота на территории предприятия так и не обеспечиваются. Власти не закрывают организации, чтобы не терять возможность извлечения частной выгоды из такого положения дел, ведь наличие причин для проверок предоставляет властям условия для систематического латания «бюджетных дыр» за счёт предпринимателей.

Суммы «благотворительных» отчислений становятся своего рода ежемесячным налогом, причём в эту сумму входят и иные ежемесячные поборы бизнеса - например, отчисления в ГИБДД, что также приравнивается бизнесом к «благотворительности»:

В месяи уходит на благотворительность 100-150 тыс. руб. Сюда входят и отчисления в ГИБДД. В иентре заливаем бетон, приходят всякие - вам нужно спецразрешение... В общем, пришлось постоянную ставку в ГИБДД оформить. Теперь нас не трогают (бизнес, производство, собственник). 
Описанная выше ситуация показывает взаимоотношения с бизнесом, который не выполняет требования власти, и иллюстрирует взаимодействие с особо «неугодными» организациями, на которые можно систематически оказывать давление.

Отношения силы — это один из возможных сценариев развития патримониальной системы; переход от взаимоотношений обмена привилегий на лояльность к прямому давлению.

\section{Локальное сообщество: добровольная или обязательная благотворительность?}

Благотворительность, основанная на патримониальном авторитете или прямом давлении, обусловлена внешними для бизнеса причинами. Но может ли благотворительность быть добровольной в случае взаимодействия с локальным сообществом, ведь видимого принуждения для бизнеса нет? Бизнес вовлекается в поддержку локального сообщества, оказывая помощь местным школам, детским садам и спортивным школам, центру реабилитации, обществу ветеранов, центру социальной защиты, школеинтернату, церкви и др. Количество запросов к бизнесу и объемы оказываемой предпринимателями поддержки зависят от размера и финансового положения организации. Так, собственники микропредприятий упоминали о запросах нескольких просителей, которые те делали один-два раза в год. Речь шла о некрупных суммах (1000-5000 руб.) или о выделении материалов. Собственники более крупных предприятий малого и среднего бизнеса говорили о том, что запросы могут поступать несколько раз в день и достигать иногда 50 тыс. руб. (в среднем назывались суммы 5 000-10 000 руб. на одного просителя). Также оказывается и нефинансовая помощь (выделение ресурсов, материалов). Основными причинами обращений являются ремонт, проведение праздников (например, День инвалида, Новый год), финансирование поездок детей на соревнования или выступления и проч.

Далее мы опишем, почему бизнесмены осуществляют благотворительность, каким образом устанавливается баланс отношений между местным бизнесом и сообществом.

\section{Благотворительность «своему кругу»}

Благотворительность бизнеса связана с солидарностью, с чувством принадлежности бизнесменов к локальному сообществу. Помощь бизнесмена зависит от того, кого он считает «своими», а кого не включает в этот круг. Данная линия анализа оказалась близкой к логике, представленной в работе О. Оберемко, где анализируется добровольная личная благотворительность малого бизнеса [Оберемко 2007]. Предприниматель осуществляет благотворительность, следуя логике гемайншафт, которая требует от него принятия общинных ролей «надёжного друга», «хорошего соседа», «хорошего хозяина», «отзывчивого человека». Однако благотворительная деятельность предпринимателя распространяется не на всё сообщество, а на «свой круг».

Основной причиной помощи является личностная мотивация (личные знакомства и переживания). В данном случае предприниматель оказывает поддержку по запросам от людей, организаций, которые ассоциируются со «своим кругом». Также помощь оказывается по инициативе самих предпринимателей.

Самый близкий круг «своих» ассоциируется с родными и друзьями. Чаще всего предприниматели поддерживают школы, где учатся их дети, и спортивные секции. Помощь в этих случаях оказывается не только своему ребёнку, но всему классу, школе. Например, предприниматели покупают спортивную форму команде сына, осуществляют ремонт класса, где учится ребёнок.

Что касается частных предпринимателей, частного и мелкого бизнеса, они, как правило, заинтересованы в помощи, когда дети учатся в школе (школа, директор). 
«Своими» для предпринимателей являются люди, входящие не только в узкий круг; эта категория шире, в неё входят хорошие знакомые, прошлые коллеги по работе, бывшие учителя. Поддержка оказывается не только знакомым, но всей организации, сообществу, к которым они принадлежат. Например, предприниматель помогает школе, где получал диплом, где работают его бывшие учителя. Эти люди лично знакомы (или знакомы через знакомых) с предпринимателем и являются местными жителями:

Сделали столовую, в которой я получал диплом, ну, косметический ремонт (бизнес, услуги, собственник).

В круг «своих» включаются также просители из «дальнего» круга. Те, кому оказывается помощь, не обязательно должны быть сами знакомы предпринимателю, однако содействие связано с личным мотивом, «личным переживанием». Например, предприниматель поддерживает ветеранов района. Это объясняется тем, что у него самого пожилые родители, он чувствует проблемную ситуацию:

Почему предприниматели идут? Что касается работы нашей организации, ветеранов, у них у самих пожилье родители, понимают, что на одну пенсию не прожить... Малую радость хотя бы - газету выписать - доставить... Понимают эту ситуацию (Совет ветеранов, президент).

Предприниматели не ждут благодарности от «своего» круга в ответ на благотворительность. Часто бизнесмены даже не рассказывали в интервью обо всех тех, кому они помогают, описывая лишь небольшую часть оказываемой поддержки. Осуществление благотворительности сами предприниматели объясняют существованием внутренних и даже сокровенных мотивов, таких как личная заинтересованность, совесть, вера в Бога («жить по совести», «Бог дал - необходимо отдавать», «лично тронуло»).

Я считаю, что это на уровне внутреннего состояния человека-бизнесмена, который принимает для себя это решение - помогать или нет. Хвалиться этим не нужно. Поэтому, если перечислять, кому мы помогаем... это не для того, чтобы получить грамоту или письмо (бизнес, торговля, собственник).

В условиях малого города и плотных социальных связей круги «своих» более интенсивны, так как «все друг друга знают». В малом городе у человека много знакомых, друзей, здесь живут расширенные семьи родственников, всё делается «по дружбе», по знакомству. За благотворительной помощью обращаются те, кого предприниматель знает.

Помогают - город же маленький, все знают, к кому можно обратиться, друзья по спорту помогают, казачье общество, с ними дружим, все по дружбе (спортивная школа, директор);

Ну, как ни странно, я в этом городе достаточно давно живу, знаю всех и вся. Конечно, ко мне знакомые обращаются (бизнес, сельское хозяйство, собственник);

Проблема маленького города, что очень много друзей-знакомых. Также родственники там... дальние... близкие. Особенности бизнеса в маленьком городе, что большая зависимость от друзей, от родственников (бизнес, недвижимость, собственник).

Контроль расходования средств не осуществляется, поскольку известны личности просителей. Необходимость как финансового, так и социального контроля исчезает, так как существует доверие к знакомым, к «своему» кругу: 
Просто оказываем помощь, и всё. Мы же не миллионами оказываем. Я как бы пытаюсь все-таки людям доверять. Причём как бы я знаю людей, которые просят оказать помощь. Я знаю, что уж они точно не поедут и эти деньги не прогуляют (бизнес, услуги, собственник).

До сих пор мы опирались в своём анализе на понятие «общинная логика» (Ф. Тённис) и на свойственное ей представление о «своих мирах», тем самым во многом подтверждая выводы, сделанные О. Оберемко. Но что является непосредственным стимулом к оказанию благотворительности? По мнению О. Оберемко, стимул поддержки - это необходимость реализации идентичности предпринимателя как свободной активной деятельности. Однако проведённое исследование показывает, что добровольный характер благотворительной деятельности ставится под вопрос, что будет подробно описано далее.

\section{Баланс взачмоотношений между бизнесом и сообществом}

Согласно структурно-функциональному подходу отсутствие отказов предпринимателей на просьбы о благотворительности объясняется подчинением поведения бизнесменов существующим в сообществе нормам солидарности. Благодаря тому что социальные нормы интернализированы, бизнесмены воспринимают свою благотворительную деятельность по отношению к сообществу как «добровольную». Однако во избежание оппортунистического поведения и нарушения норм солидарности местное сообщество вводит социальный контроль и социальные санкции. В своей деятельности бизнес, помимо логики солидарности, руководствуется рациональной логикой, присущей коммерческой природе бизнеса. В том случае, когда нормы солидарности входят в конфликт с рациональной логикой бизнеса, во избежание социальных санкций бизнес начинает поиск баланса в отношениях с локальным сообществом.

Предприниматели отмечали социальный порядок помощиํ. Такие фразы, как «традиционно», «да куда деваться», указывают на то, что запросы воспринимаются как должное, само собой разумеющееся, то, от чего нельзя отказаться, что свидетельствует о соблюдении предпринимателями норм поддержки локального сообщества:

У нас уже и центтр реабилитации - традиционно, инвалиды - традиционно, по зрению тоже традииионно. Каждый год им что-то... Оказываем помощь. Каждый год мы всё это оказываем. У меня дети уже, как обычно, приходят к Новому году. Говорят: ну, мы к вам опять пришли к Новому году. Вот ты собираешь подарки там, раз - им отдал (бизнес, недвижимость, собственник);

Ну, обращаются - периодика, печать... Оплатить то, помоги туда... Да куда деваться? В принциие, не хлебом одним сыт человек (бизнес, транспорт, собственник).

Укоренённость в локальном сообществе, неформальные, плотные социальные связи малого города накладывают ограничения на рациональную экономическую деятельность предпринимателя. Для сохранения норм солидарности сообществом осуществляется социальный контроль, интенсивный в малом городе. Так, в условиях, когда «все друг друга знают», информация о финансовом состоянии предпринимателей, об их помощи и отказах заметна для сообщества:

В маленьком городе через родителей, через детей слухи за короткое время дойдут куда надо (бизнес, услуги, собственник);

9 Такой порядок был отмечен нами и в полевой экспедиции, проведённой во время Летней социологической практики Лаборатории экономико-социологических исследований в Каргополе (Архангельская область), в 2014 г. 
Я же знаю, что он может помочь, а он не помогает. Ну, некрасиво. Живёшь в этом городе и ничего не делаешь для других - только набивает себе карманы... Так тоже неправильно (бизнес, недвижимость, собственник).

В случае систематических отказов возникает опасность осуществления сообществом социальных санкций, которые угрожают личной репутации, ухудшают общественное мнение о предпринимателе, в результате чего он будет «выглядеть некрасиво»:

Если отказывают - на деловой репутации не скажется. На общественном мнении - скорее всего (спортивная школа, директор);

Можно отказаться от всего, но ты жживёшь в этом городе. Можно послать всех и набивать свои карманы. Но просто рано или поздно тыл к кому-нибудь обратишься за помощью, даже просто с людьми общаясь. Ну, кто-то расскажет, что ко мне те приходили, я им помог, я детям помог, этот тому же музею помог, а ты скажешь: "Я послал всех, никому не помогал». Тогда ты как предприниматель в их лице уюе будешь некрасиво выглядеть (бизнес, недвижимость, собственник).

Личная же репутация является наиболее ценным активом в малом городе, ведь предпринимателя воспринимают прежде всего лично. В условиях тесных социальных связей личная репутация влияет на экономическую деятельность всего предприятия:

Так как я, индивидуальный предприниматель, то меня просители рассматривают лично. Но я всем говорю, что помогает весь коллектив нашей организащии (бизнес, услуги, собственник).

Как соблюдается баланс взаимоотношений между бизнесом и сообществом? Со стороны сообщества соблюдается баланс количества и сумм запросов. Просители учитывают финансовое состояние предпринимателей. В малом городе просителям известно о том, как развиваются предприятия, каково их финансовое положение. Экономическое развитие предприятий является основным фактором при определении количества, а также величины суммы запросов:

Как заведено в любом маленьком городе, как мы начали копошиться, появилось живое предприятие, сразу к нам стали приходить. Идут все - детям-сиротам, обществу инвалидов, выписка журналов. В большом городе мы бы затерялись, не были бы так на виду (бизнес, производство, собственник);

Мы сейчас стали обращаться к бизнесу только в самых крайних случаях, мы жже видим, что всем сейчас непросто (спортивная школа, директор).

Но не только финансовое положение предпринимателя важно; просителям необходимо чувствовать границу, когда баланс запросов нарушается:

Нy, она (Директор реабилитационного центра. - М. Ч.) знает, что злоупотреблять этим не надо, не только по отношению ко мне. Она придёт ко мне пять раз, а на шестой скажу ей: «Не приходите» (бизнес, сельское хозяйство, собственник).

Суммы запросов невелики. Иногда предпринимателям очерчивается проблема, а далее они сами решают, в каком объёме оказать поддержку. Таким образом, просители понимают, что даже при хорошем отношении предпринимателя к просителям следует не злоупотреблять просьбами. 
Для предпринимателя также существует личный баланс количества запросов и средств, которые он готов потратить на благотворительность в тот или иной период времени (как правило, сумма зависит от финансовых возможностей благотворителя). Эта сумма делится среди пришедших просителей: первым достаётся бо́льшая сумма; следующим не отказывают, но они получают меньшие суммы:

Да, могут раз в неделю приходить, а могут каждый день и даже по многу раз. Никому не отказываю, стараюсь помогать. Бывает так, что в один день сначала отдал 10 тысяч, потом ещё пять тысяч. Пришёл третий - ну, пришлось ему отказать, то есть дать тысячу (бизнес, строительство, собственник).

В том случае, если комфортная сумма для благотворителя превышена, начинается поиск компромисса - например, просьбы могут перенаправляться другим бизнесменам. Если же предприниматель не может или не хочет оказывать поддержку, он никогда не скажет об этом напрямую. Отказы просителям он объясняет своим финансовым положением:

Могут сказать: «Нет у меня сейчас денег, я не могу вам дать». А так, итобы совсем отказывать, я таких не знаю (бизнес, производство, собственник).

Выше было описано нежелание предпринимателей демонстрировать благотворительную помощь. Такое нежелание обусловлено стремлением к сохранению баланса взаимоотношений с локальным сообществом. Широкое освещение благотворительной деятельности - например, при размещении информации в местной газете - повлечёт возрастание запросов просителей. Бизнес же в случае большого количества просьб вынужден будет отказывать, что ухудшит репутацию руководителя:

Понимаете, я не думаю, что мы все видим везде только деньги и как заработать. Безусловно, помогаем и видим, где надо, но я не хочу рекламу делать. Ко мне часто приходят и говорят, что помочь надо. Говорят, потом в газете напишем, а я говорю: не надо, сделаете мне медвежью услугу - напишите, что я помог, и ко мне ещё 20 ходоков прибегут (бизнес, строительство, директор).

Итак, в малом городе при оказании помощи бизнесмены сталкиваются с конфликтом рациональной логики бизнеса, а также требований норм солидарности, которые должен соблюдать предприниматель как член локального сообщества. Выходом из этой ситуации является поиск баланса отношений между бизнесом и сообществом, который соблюдается как сообществом, так и бизнесменами, что соответствует консенсусу, лежащему в основе достижения общей цели - выживания социального организма.

\section{Заключение}

В статье анализировались мотивы и барьеры, воздействующие на благотворительность малого и среднего бизнеса. Баланс отношений между бизнесом, властью и локальным сообществом на благотворительности бизнеса. Но какой тип отношений ведёт к наиболее устойчивой и значимой по объёмам благотворительности?

Критическая теория объясняет благотворительность как средство построения имиджа, направленное на достижение частных интересов бизнеса в долгосрочной перспективе. Однако в некрупном городе реальная информация о предприятиях видна как власти, так и всему сообществу, поэтому объёмы и стабильность благотворительности, оказываемой во имя построения имиджа бизнеса, минимальны. 
Отношения с локальным сообществом формируют социальный порядок, имеющий принудительную силу для бизнесменов как членов сообщества. Бизнес выстраивает отношения с местным сообществом, находя баланс между рациональной логикой ведения бизнеса и логикой подчинения нормам солидарности. Локальный порядок обеспечивает устойчивость благотворительных пожертвований, однако объёмы средств, выделяемых бизнесом на такой тип поддержки, невелики.

По М. Веберу, патримониальный тип господства является одним из наиболее устойчивых видов взаимодействия наряду с другими формами господства или в сравнении с прямым применением силы, так как основан на вере в легитимность власти. Но как обстоит дело на практике? В теоретической части мы задались вопросом о том, насколько патримониальная система устойчива в России, несмотря на существование значительных недостатков такой системы для бизнеса. Возможно ли, что, оценивая все «за» и «против» системы, бизнесу будет выгоднее взаимодействовать с властью в рамках рациональнолегального господства, основанного на формальных правилах? Анализ поселения, в котором недавно произошла смена власти и осуществляется борьба с коррупцией, позволил выявить устойчивость и (или) неустойчивость патримониальной системы, отношение к ней бизнесменов, а также описать влияние, которое оказывает на систему и благотворительность бизнесменов формализация взаимодействия бизнеса и власти.

Система патримониальных обменов устойчива в покрытом выборкой поле. В рассматриваемом поселении мы столкнулись с ситуацией, когда при смене власти бизнес потерял возможность доступа к административному ресурсу. Система патримониальных обменов продолжала существовать со «своими» фирмами нового главы, местный же бизнес столкнулся с плотным заслоном из административных барьеров. Однако это не привело к негативному отношению бизнеса к патримониальной системе, и предприниматели продолжают ожидать взаимности от власти, говорят о праве администрации требовать социальных отчислений в случае, если власть выделяет необходимые для выживания бизнеса ресурсы. Иначе говоря, в ситуации, когда местному бизнесу не нужно демонстрировать лояльность властям, он не стремится перейти к логике легального господства, рациональных правил, но ждёт возврата прежней патримониальной системы. Ситуация эта характерна для бизнеса, наиболее зависимого от бюджетных ресурсов.

Переход к рационально-легальному типу, формализация отношений между бизнесом и властью являются причинами снижения оказываемой предпринимателями поддержки в рассматриваемом городском поселении. Попытки государства снизить коррупционные интересы местных властей усилением прокурорских проверок приводит к сокращению количества и сужению круга партнёров, с которыми выстраиваются патримониальные обмены. Взаимодействие осуществляется с теми, с кем отношения уже выстроены, то есть со «своими». Отсутствие же отношений с местным бизнесом влечёт за собой падение уровня благотворительности местного малого и среднего бизнеса.

Формализация отношений с бизнесом, которая выражается в упрощении проверок, в снижении давления, в выплате бизнесом значимых сумм налогов, приводит к негативному отношению бизнеса к запросам со стороны властей. Предприниматели, которые стараются соблюдать (хотя часто и не в полном объёме) требования властей, придерживаются позиции «мы платим налоги - это и есть социальная поддержка». Такая позиция близка бизнесу, менее зависимому от государственных ресурсов. Вновь стремление к рационально-легальному типу господства, отсутствие неформальных отношений с властями сокращают благотворительность бизнеса. В условиях несамостоятельности малого и среднего бизнеса, ресурсной зависимости бизнеса от государства осуществление наиболее значимой по объёмам и устойчивой благотворительности в городском поселении возможно при учёте экономических интересов бизнеса и построении отношений с местными властями. 


\section{Ограничения работы и направления дальнейших исследований}

Ограничением работы, по нашему мнению, является использование нами термина «благотворительность» при описании поддержки бизнесом местного сообщества (взаимодействие с властью также направлено на поддержку города и местного населения). В высказываниях бизнесменов и других респондентов никогда не встречалось слово «благотворительность», всегда речь шла о «помощи», «поддержке». Можем ли мы для описания неформальных взаимоотношений внутри локального сообщества оперировать таким формальным термином, как «благотворительность», который соответствует миру рационально-легального типа господства?

Дополнительное ограничение связано с содержанием понятия «благотворительность». В работе дано широкое определение термина: несистематическая помощь нуждающимся за пределами легальных требований к бизнесу. Однако такое широкое понимание включает ряд более узких и тонких понятий: благотворительность как альтруистический дар, реципрокный обмен и отношения лояльности.

Выстраиваются ли в сообществе институты, правила, по которым бизнес оказывает поддержку или отказывает? Кому бизнес помогает, а кому можно отказать? На каком основании осуществляется отказ? Эти важные вопросы необходимо раскрыть в дальнейшем. И наконец, необходимо проанализировать данные о факторах, которые ранее влияли на формирование отношений внутри сообщества. 


\section{Приложение}

Таблица П1

\section{Описание полевых данных}

\begin{tabular}{|c|c|c|c|c|c|c|c|}
\hline $\begin{array}{l}\text { Тип } \\
\text { биз- } \\
\text { неса }\end{array}$ & & $\begin{array}{c}\text { Вид } \\
\text { экономической } \\
\text { деятельности }\end{array}$ & $\begin{array}{l}\text { Направление } \\
\text { деятельности }\end{array}$ & $\begin{array}{c}\text { Год } \\
\text { основания } \\
\text { организации }\end{array}$ & $\begin{array}{l}\text { Пол } \\
\text { респон- } \\
\text { дента }\end{array}$ & $\begin{array}{c}\text { Количество } \\
\text { сотрудников } \\
\text { (чел.) }\end{array}$ & $\begin{array}{c}\text { С какого года ре- } \\
\text { спондент прожива- } \\
\text { ет в поселении }\end{array}$ \\
\hline \multirow{4}{*}{ 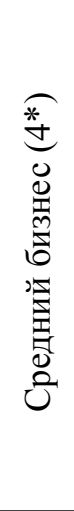 } & 1 & Строительство & $\begin{array}{c}\text { Дорожное строи- } \\
\text { тельство }\end{array}$ & 1975 & Муж. & 250 & Коренной житель \\
\hline & 2 & Строительство & $\begin{array}{l}\text { Все типы строи- } \\
\text { тельства }\end{array}$ & 1991 & Муж. & $\begin{array}{c}100-150 \text { (в } \\
\text { зависимости от } \\
\text { сезона) }\end{array}$ & Коренной житель \\
\hline & 3 & Производство & Бетонный завод** & 2003 & Муж. & $\begin{array}{c}40 \text { в штате; } \\
40 \text { на трудо- } \\
\text { вом договоре; } \\
40 \text { сезонных } \\
\text { работников }\end{array}$ & Коренной житель \\
\hline & 4 & Услуги & $\begin{array}{c}\text { Сеть медицинских } \\
\text { центров }\end{array}$ & 2010 & Муж. & 200 & 1994 г. \\
\hline \multirow{11}{*}{ 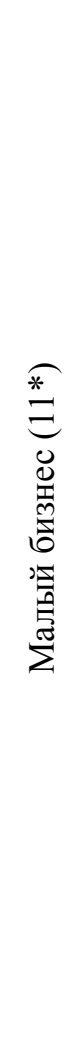 } & 5 & Торговля & $\begin{array}{c}\text { Продажа материа- } \\
\text { лов для строитель- } \\
\text { ства }\end{array}$ & 1991 & Муж. & 20 & 1972 г. \\
\hline & 6 & Торговля & $\begin{array}{c}\text { Оптовая продажа } \\
\text { продовольственной } \\
\text { продукции }\end{array}$ & 2011 & Муж. & 20 & Коренной житель \\
\hline & 7 & Торговля & $\begin{array}{c}\text { Оптовая продажа } \\
\text { продовольственной } \\
\text { продукции }\end{array}$ & 1992 & Муж. & 50 & Коренной житель \\
\hline & 8 & Производство & $\begin{array}{c}\text { Керамзитовый за- } \\
\text { вод }\end{array}$ & 2000 & Муж. & $80-100$ & Коренной житель \\
\hline & 9 & Производство & $\begin{array}{c}\text { Железобетонные } \\
\text { изделия (ЖБИ) }\end{array}$ & 2003 & Муж. & 50 & Коренной житель \\
\hline & 10 & Производство & Производство пива & 2002 & Муж. & 15 & 1988 г. \\
\hline & 11 & Транспорт & Перевозки грузов & 1991 & Муж. & 23 & Коренной житель \\
\hline & 12 & Строительство & $\begin{array}{c}\text { Все типы строи- } \\
\text { тельства }\end{array}$ & 1993 & Муж. & 30 & Коренной житель \\
\hline & 13 & Услуги & $\begin{array}{l}\text { Охранное пред- } \\
\text { приятие }\end{array}$ & 2000 & Муж. & $80-100$ & 1988 г. \\
\hline & 14 & Услуги & Пожарный аудит & 2001 & Муж. & 16 & Коренной житель \\
\hline & 15 & $\begin{array}{c}\text { Сельское хо- } \\
\text { зяйство, лесное } \\
\text { хозяйство }\end{array}$ & $\begin{array}{c}\text { Производство сель- } \\
\text { скохозяйственной } \\
\text { продукции }\end{array}$ & 1999 & Муж. & 15 & Коренной житель \\
\hline \multirow{5}{*}{ 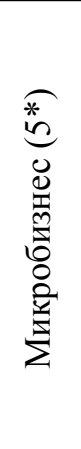 } & 16 & Торговля & Продажа в розницу & 1995 & Муж. & 5 & 1993 г. \\
\hline & 17 & Строительство & Производство окон & 2006 & Муж. & 13 & 1988 г. \\
\hline & 18 & $\begin{array}{c}\text { Сельское хо- } \\
\text { зяйство, лесное } \\
\text { хозяйство }\end{array}$ & Лесопереработка & 2013 & Муж. & 14 & Коренной житель \\
\hline & 19 & Услуги & $\begin{array}{c}\text { Бухгалтерские } \\
\text { услуги }\end{array}$ & 2005 & Муж. & 6 & Коренной житель \\
\hline & 20 & $\begin{array}{c}\text { Операции с } \\
\text { недвижимым } \\
\text { имуществом }\end{array}$ & $\begin{array}{c}\text { Операции с не- } \\
\text { движимым имуще- } \\
\text { ством }\end{array}$ & 1992 & Муж. & 6 & 1983 г. \\
\hline
\end{tabular}

* Количество опрошенных организаций.

** Оборот компании 600 млн руб. в год, поэтому бизнес причислен к среднему. 
Таблица П2

Схема основных кодов

\begin{tabular}{|c|c|}
\hline Администрация & Сообщество \\
\hline $\begin{array}{l}\text { Корыстные интересы администрации: } \\
\text { - «свои» фирмы при бюджете; } \\
\text { - административные барьеры } \\
\text { Отношения обмена: } \\
\text { - невыполнение обещаний; } \\
\text { - ожидание обмена; } \\
\text { - отсутствие у администрации права просить; } \\
\text { - отсутствие авторитета власти } \\
\text { Формализация отношений власти с бизнесом: } \\
\text { - усиление проверок власти; } \\
\text { - антикоррупционная активность бизнеса; } \\
\text { - требование оформления благотворительности; } \\
\text { - упрощение проверок бизнеса; } \\
\text { - выполнение требований администрации; } \\
\text { - позиция бизнеса: социальная поддержка - } \\
\text { «платить налоги» } \\
\text { Отношения силы: } \\
\text { - запросы администрации; } \\
\text { - боязнь власти; } \\
\text { - рычаги давления; } \\
\text { - вынужденная «благотворительность» } \\
\text { Экономическая ситуация: } \\
\text { - конкуренция; } \\
\text { - сложность тендерных процедур; } \\
\text { - бизнес закрывается, кризис }\end{array}$ & $\begin{array}{l}\text { Помощь «своему» кругу: } \\
\text { - помощь ближнему кругу; } \\
\text { - помощь среднему кругу; } \\
\text { - помощь дальнему кругу } \\
\text { Условия малого города: } \\
\text { - тесные социальные связи; } \\
\text { — социальный контроль (быстрое распростране- } \\
\text { ние информации); } \\
\text { - социальные санкции (утеря репутации) } \\
\text { Баланс отношений бизнеса с сообществом: } \\
\text { - комфортная сумма помощи; } \\
\text { - распределение комфортной суммы; } \\
\text { - отсутствие и (или) оправдание отказов; } \\
\text { - посильные суммы; } \\
\text { - перенаправление просителей } \\
\text { Баланс отношений сообшества с бизнесом: } \\
\text { - заведенный порядок помощи; } \\
\text { - учет финансового положения предпринимате- } \\
\text { лей; } \\
\text { - частота запросов; } \\
\text { - суммы запросов }\end{array}$ \\
\hline
\end{tabular}

\section{Литература}

Ассоциация адвокатов России за права человека. 2014. Коррупщия в России: независимый годовой доклад всероссийской антикоррупиионной общзественной приёмной «Чистые руки». URL: http:// rusadvocat.com/report_2013_2014.docx

Ассоциация адвокатов России за права человека. 2015. Коррупция в России: независимылй годовой доклад всероссийской антикоррупиионной общественной приёмной «Чистые руки». URL: http:// rusadvocat.com/corp010915.docx

Благов Ю. Е., Литовченко С. Е., Иванова Е. А. (ред.). 2008. Доклад о соииальных инвестициях в России - 2008. М.: Ассоциация менеджеров.

Благов Ю. Е., Соболев И. С. (ред.). 2014. Доклад о социальных инвестициях в России - 2014: к созданию цеенности для бизнеса и общества. СПб.: АТМ Книга.

Ильин В. И. 2006. Драматургия качественного полевого исследования. СПб.: Интерсоцис.

Князев В. Г., Слепов В. А. 2012. Финансы: Учебник. Изд. 3-е, переработанное и дополненное. М.: Магистр; ИНФРА-М. 
Краснодарстат. 2016. Структура валового регионального продукта. URL: http://krsdstat.gks.ru/wps/ wcm/connect/rosstat_ts/krsdstat/resources/6f43dd004887167db5bff5f7еaа5adf2/Структура+валового+p егионального+продукта.htm

Кузина О. Е., Чернышёва М. В. 2015. Корпоративная благотворительность и ответственность: обоснование понятий. Мониторинг общественного мнения: экономические и социальные перемены. 4: $154-165$.

Кузина О. Е., Чернышёва М. В. 2016. Корпоративная благотворительность и корпоративная филантропия: экономико-социологический анализ. Bопросы экономики. 3: 115-130.

О контрактной системе в сфере закупок товаров, работ, услуг для обеспечения государственных и муниципальных нужд. 2013. 5 апреля. Федеральный закон № 44-Ф3. URL: http://base.garant. $\mathrm{ru} / 70353464 /$

О предельных значениях выручки от реализации товаров (работ, услуг) для каждой категории субъектов малого и среднего предпринимательства. 2013. 9 февраля. Постановление Правительства РФ № 101. URL: http://base.garant.ru/70313430/

О предельных значениях выручки от реализации товаров (работ, услуг) для каждой категории субъектов малого и среднего предпринимательства. 2015. 13 июля. Постановление Правительства РФ № 702. URL: http://ivo.garant.ru/\#/document/71134484

О развитии малого и среднего предпринимательства в Российской Федерации. 2007. 11 июля. Федеральный закон № 209-Ф3. URL: http://ivo.garant.ru/\#/document/12154854

Оберемко О. 2006. Благотворительность в моём городе: анализ перспектив благотворительности в городах Подмосковья. М.: Институт социальной и гендерной политики.

Оберемко О. 2007. Локальная идентичность благотворителя как представление о «территории свободы». Социальная реальность. 3: 106-116.

Перегудов С. 2003. Корпоращчи, общеество, государство: эволющия отношений. М.: Наука.

Перегудов С. 2006. Крупная корпоращия как субъект публичной политики. М.: Изд. дом ВШЭ.

Перегудов С. 2008. Корпоративное гражданство: концепџии, мировая практика и российские реалии. М.: Прогресс-Традиция.

Силуанов А. Г., Стародубровская И. В., Назаров В. С. 2011. Методологические подходы к оценке эффективности межбюджетных отношений в субъектах Российской Федерации. Экономическая политика. 1: 5-22.

Федеральная служба государственной статистики. 2016. Валовой региональный продукт по субъектам Российской Федераџии в 1998-2014 г2. URL: gks.ru/free_doc/new_site/vvp/vrp98-14.xlsx

Филиппов А. 2011. Мобильность и солидарность. Социологическое обозрение. 10 (3): 4-20.

Чеснокова В. Ф. 2010. Язык соц̧иологии. Курс лекциий. М.: ОГИ. 
Чирикова A. E. et al. 2005. Бизнес как субъект сочиальной политики: должник, благодетель, партнер? М.: Изд. дом ВШЭ; Независимый институт социальной политики.

Чирикова А. Е. 2012. Государство и бизнес: взаимодействие на поле социальной политики в современной России. Россия реформирующаяся. Вып. 11 (Отв. ред. М. К. Горшков). М.: Новый хронограф.

Чирикова А. Е., Ледяев В. Г., Сельцер Д. Г. 2014. Власть в малом российском городе: конфигурация и взаимодействие основных акторов. Полис. Политические исследования. 2: 88-105.

Чирикова А. Е., Ледяев В. Г. 2015. Власть в малых российских городах: модели взаимодействия исполнительной и представительной власти. Мир России. 3: 6-32.

Штейнберг И. Е. 2014. Логические схемы обоснования выборки для качественных интервью: «восьмиоконная» модель. Социология: 4M. 38: 38-71.

Arnove R. F. 1980. Philanthropy and Cultural Iimperialism: The Foundations at Home and Abroad. Boston: G. K. Hall.

Baumann-Pauly D., Scherer A. 2012. The Organizational Implementation of Corporate Citizenship: An Assessment Tool and Its Application at UN Global Compact Participants. Journal of Business Ethics. 115 (4): 693-705.

Besser T. L. 2012. The Consequences of Social Responsibility for Small Business Owners in Small Towns. Business Ethics: A European Review. 21 (2): 129-139.

Carroll A. B. 1991. The Pyramid of Corporate Social Responsibility: Toward the Moral Management of Organizational Stakeholders. Business Horizons. 34 (4): 39-48.

Fernandez J. F. F., Delgado J. B., Garcia N. V. 2007. The Collaborative Creation of a Strategic Stakeholder Management Approach in a Small Spanish Enterprise. Corporate Governance. 7: 524-533

Freeman E. 1984. Strategic Management: A Stakeholder Approach. Boston: Pittman-Ballinger.

Friedman M. 1970. The Social Responsibility of Business is to Increase Its Profits. New York Times Magazine. September 13. URL: http://www.colorado.edu/studentgroups/libertarians/issues/friedman-soc-respbusiness.html

Garriga E., Melé D. 2004. Corporate Social Responsibility Theories: Mapping the Territory. Journal of Business Ethics. 53 (1): 51-71.

Gautier A., Pache A. 2013. Research on Corporate Philanthropy: A Review and Assessment. Journal of Business Ethics. 126 (3): 343-369.

Husted B. W. 2006. Corporate Social Responsibility in the Multinational Enterprise: Strategic and Institutional Approaches. Journal of International Business Studies. 6: 838-849.

Jenkins H. 2004. A Critique of Conventional CSR Theory: An SME Perspective. Journal of General Management. 29: 37-57. 
Jenkins H. 2006. Small Business Champions for Corporate Social Responsibility. Journal of Business Ethics. 67: 241-256.

Lähdesmäki M., Suutari T. 2012. Keeping at Arm's Length or Searching for Social Proximity? Corporate Social Responsibility as a Reciprocal Process Between Small Businesses and the Local Community. Journal of Business Ethics. 108 (4): 481-493.

Leisinger K. 2007. Corporate Philanthropy: The «Top of the Pyramid». Business and Society Review. 112 (3): $315-342$.

Longo M., Mura M., Bonoli A. 2005. Corporate Social Responsibility and Corporate Performance: The Case of Italian SMEs. Corporate Governance. 5: 28-42.

Murillo D., Lozano J. 2006. SMEs and CSR: An Approach to CSR in Their Own Words. Business Ethics. 67: $227-240$.

Parsons T. 1964. Evolutionary Universals in Society. American Sociological Review. 29 (3): 339-357.

Parsons T. 1991. The Social System. London: Routledge.

Perrini R., Russo A., Tencati A. 2007. CSR Strategies of SMEs and Large Firms. Evidence from Italy. Journal of Business Ethics. 74: 285-300.

Perrini R., Russo A. 2010. Investigating Stakeholder Theory and Social Capital: CSR in Large firms and SMEs. Journal of Business Ethics. 91 (2):207-221.

Prasad A., Holzinger I. 2013. Seeing through Smoke and Mirrors: A Critical Analysis of Marketing CSR. Journal of Business Research. 66 (10): 1915-1921.

Preuss L., Perschke J. 2010. Slipstreaming the Larger Boats: Social Responsibility in Medium-Sized Firms. Journal of Business Ethics. 92: 531-551.

Quinn J. 1997. Personal Ethics and Business Ethics: The Ethical Attitudes of Owner/Managers of Small Business. Journal of Business Ethics. 16 (2): 119-127.

Rajak D. 2008. «Uplift and Empower»: The Market, Morality and Corporate Responsibility on South Africa's Platinum Belt. Research in Economic Anthropology. 28: 297-324.

Roelofs J. 2003. Foundations and Public Policy: The Mask of Pluralism. Albany: SUNY Press.

Russo A., Tencati A. 2009. Formal vs Informal CSR Strategies: Evidence from Italian Micro, Small, MediumSized and Large Firms. Journal of Business Ethics. 85: 339-353.

Snider J., Hill R. P., Martin D. 2003. Corporate Social Responsibility in the 21st Century: A View from the World's Most Successful Firms. Journal of Business Ethics. 48 (2): 175-187.

Spence L. 1999. Does Size Matter: The State of the Art in Small Business Ethics. Business Ethics: A European Review. 8 (3): 163-174. 
Spence L. J. 2007. CSR and Small Business in a European Policy Context: The Five C's of CSR and Small Business Research Agenda. Business and Society Review. 112: 533-552.

Spence L., Habisch A., Schmidpeter R. (eds) 2004. Responsibility and Social Capital: The World of Small and Medium Sized Enterprises. Houndmills, UK: Palgrave Macmillan.

Spence L. J., Rutherfoord R. 2003. Small Business and Empirical Perspectives in Business Ethics: Editorial. Journal of Business Ethics. 47 (1): 1-5.

Sundaram A., Inkpen A. 2004. The Corporate Objective Revisited. Organization Science. 15 (3): 350-363.

Taneja S., Taneja P., Gupta R. 2011. Researches in CSR: A Review of Shifting Focus, Paradigms and Methodologies. Journal of Business Ethics. 101: 343-364.

Tilley F. 2000. Small Firm Environmental Ethics: How Deep Do They Go? Business Ethics: A European Review. 9 (1): 31-41.

Vázquez-Carrasco R., López-Pérez M. E. 2013. Small \& Medium-Sized Enterprises and Corporate Social Responsibility: A Systematic Review of the Literature. Quality \& Quantity journal. 47: 3205-3218.

Vo L. C. 2011. Corporate Social Responsibility and SMEs: A Literature Review and Agenda for Future Research. Problems and Perspectives in Management. 9 (4): 89-97.

Weber M. 1978. Economy and Society. Berkeley, CA: University of California Press. 


\title{
DEBUT STUDIES
}

\section{Marina Chernysheva}

\section{Charity of Small- \& Medium-Sized Businesses in a Russian Small Town: An Empirical Analysis}

\author{
CHERNYSHEVA, Marina - \\ postgraduate student, \\ Department of Sociology, \\ National Research University \\ Higher School of Economics. \\ Address: 20 Myasnitskaya str., \\ Moscow, 101000, Russian \\ Federation.
}

Email: mchernysheva@hse.ru

\begin{abstract}
The paper presents the results of an empirical study on the charity of smalland medium-sized businesses in a small Russian town. The aim of this article is to reveal motivations and barriers for small- and medium-sized businesses to participate in charitable activities. By the charity of a business, we mean a non-systematic provision of financial support to those in need. Different theoretical approaches are applied to explain the motivations for charitable activity in business. Critical theory implies that charity is used as an ideological tool aiming for a positive public image. Theories of solidarity conceptualize charity as a moral obligation to conform to the norms of
\end{abstract} the community. In the model of patrimonial domination, the authority distributes privileges in exchange for loyalty.

This study was conducted in 2015-2016 in a small Russian town; 21 semi-structured interviews were carried out with the owners of small- and medium-sized businesses. In addition, 13 interviews were conducted with recipients of business donations and experts in the field of charity (including leaders of non-profit organizations, schools, local media, and government representatives). The empirical results show that business charity is a result of the relationships between businesses, the local community, and local authorities. The local community sets a stable social order of charity in a small town. However, the most stable and significant charitable donations from businesses are possible only in the system of patrimonial exchanges.

Keywords: business charity; patrimonial authority; critical theory; solidarity; local community; small- and medium-sized businesses.

\section{Acknowledgements}

I would like to express my sincere gratitude to Prof. Olga Kuzina for her openness and the immeasurable amount of support and guidance she has provided throughout this research.

\section{References}

Arnove R. F. (1980) Philanthropy and Cultural Imperialism: The Foundations at Home and Abroad, Boston: G. K. Hall.

Association of Russian Lawyers for Human Rights (2014) Korruptsiya v Rossii: nezavisimyiy godovoy doklad vserossiyskoy antikorruptsionnoy obshchestvennoy priemnoy "Chistyie ruki" [Corruption in Russia: An Independent Annual Report of the All-Russian Anti-Corruption Public Reception of "Clean Hands"]. Available at: http://rusadvocat.com/report22013_2014.docx (accessed 17 September 2016) (in Russian). 
Association of Russian Lawyers for Human Rights (2015) Korruptsiya v Rossii: nezavisimyiy godovoy doklad vserossiyskoy antikorruptsionnoy obschestvennoy priemnoy "Chistyie ruki" [Corruption in Russia: An independent Annual Report of the All-Russian Anti-Corruption Public Reception of "Clean Hands"]. Available at: http://rusadvocat.com/corp010915.docx (accessed 16 September 2016) (in Russian).

Baumann-Pauly D., Scherer A. (2012) The Organizational Implementation of Corporate Citizenship: An Assessment Tool and Its Application at UN Global Compact Participants. Journal of Business Ethics, vol. 115, no 4, pp. 693-705.

Besser T. L. (2012) The Consequences of Social Responsibility for Small Business Owners in Small Towns. Business Ethics: A European Review, vol. 21, no 2, pp. 129-139.

Blagov Y., Sobolev I. (ed.) (2014) Doklad o sotsialnyikh investitsiyakh v Rossii - 2014: k sozdaniyu tsennosti dlya biznesa i obshchestva [Report on Social Investments in Russia - 2014: For Creation of Value for Business and Society], St. Petersburg: ATM Book (in Russian).

Blagov Y., Litovchenko S., Ivanova E. (eds.) (2008) Doklad o sotsialnyikh investitsiyakh v Rossii - 2008 [Report on Social Investments in Russia -2008], Moscow: Association of Managers (in Russian).

Carroll A. B. (1991) The Pyramid of Corporate Social Responsibility: Toward the Moral Management of Organizational Stakeholders. Business Horizons, vol. 34, no 4, pp. 39-48.

Chesnokova V. ( 2010) Yazyik sotsiologii. Kurs lektsiy [Language of Sociology. Lecture Course], Moscow: OGI (in Russian).

Chirikova A. E. (2012) Gosudarstvo i biznes: vzaimodeystvie na pole sotsialnoy politiki v sovremennoy Rossii [State and Business: Cooperation in the Field of Social Policy in Modern Russia]. Rossiya reformiruyushchayasya, vol. 11. (ed. M. K. Gorshkov), Moscow: The New Chronograph (in Russian).

Chirikova A., Ledyaev V.(2015) Vlast' v malyikh rossiyskikh gorodakh: modeli vzaimodeystviya ispolnitelnoy i predstavitelnoy vlasti [Power in Small Russian Towns: Models of Interaction of Executive and Representative Authority]. Mir Rossii, no 3, pp. 6-32.

Chirikova A., Ledyaev V., Seltser D. (2014) Vlast' v malom rossiyskom gorode: konfiguratsiya i vzaimodeystvie osnovnyikh aktorov [Authorities in a Small Russian Town: The Configuration and Interaction of the Main Actors]. Polis. Politicheskie issledovaniya, no 2, pp. 88-105.

Chirikova A., Shilova L., Lapina N., Shishkin S. (2005) Biznes kak sub'ekt sotsialnoy politiki: dolzhnik, blagodetel, partner? [Business as a Subject of Social Policy: The Debtor, Benefactor, Partner?], Moscow: HSE; Independent Institute for Social Policy (in Russian).

Federalnaya sluzhba gosudarstvennoy statistiki (2016) Valovoy regionalnyiy produkt po sub'ektam Rossiyskoy Federatsii v 1998-2014 gg. [The Gross Regional Product of the Russian Federation Subdivisions in 1998-2014]. Available at: gks.ru/free_doc/new_site/vvp/vrp98-14.xlsx (accessed 18 September 2016) (in Russian).

Fernandez J. F. F., Delgado J. B., Garcia N. V. (2007) The Collaborative Creation of a Strategic Stakeholder Management Approach in a Small Spanish Enterprise. Corporate Governance, no 7, pp. 524-533. 
Filippov A. (2011) Mobilnost i solidarnost [Mobility and solidarity]. Sotsiologicheskoe obozrenie, vol. 10, no 3, pp. 4-20 (in Russian).

Freeman E. (1984) Strategic Management: A Stakeholder Approach, Boston: Pittman-Ballinger.

Friedman M. (1970) The Social Responsibility of Business is to Increase its Profits. New York Times Magazine, September 13. Available at: http://www.colorado.edu/studentgroups/libertarians/issues/friedmansoc-resp-business.html (accessed 18 September 2016).

Garriga E., Melé D. (2004) Corporate Social Responsibility Theories: Mapping the Territory. Journal of Business Ethics, vol. 53, no 1, pp. 51-71.

Gautier A., Pache A. (2013) Research on Corporate Philanthropy: A Review and Assessment. Journal of Business Ethics, vol. 126, no 3, pp. 343-369.

Husted B. W. (2006) Corporate Social Responsibility in the Multinational Enterprise: Strategic and Institutional Approaches. Journal of International Business Studies, no 6, pp. 838-849.

Il'in V. I. (2006) Dramaturgiya kachestvennogo polevogo issledovaniya [Dramaturgy of Qualitative Field Research], St. Petersburg: Intersotsis (in Russian).

Jenkins H. (2004) A Critique of Conventional CSR Theory: An SME Perspective. Journal of General Management, no 29, pp. 37-57.

Jenkins H. (2006) Small Business Champions for Corporate Social Responsibility. Journal of Business Ethics, no 67 , pp. 241-256.

Knyazev V., Slepov V. (2012) Finansyi. Uchebnik. Izdanie 3, pererabotannoe i dopolnennoe [Finance: A Textbook. 3rd edn, revised and enlarged], Moscow: Magistr, INFRA-M (in Russian).

Krasnodarstat (2016) Struktura valovogo regionalnogo produkta [Structure of Growth Regional Product]. Available at: http://krsdstat.gks.ru/wps/wcm/connect/rosstat_ts/krsdstat/resources/6f43dd004887167db5 bff5f7eaa5adf2/Struktura valovogo regionalnogo produkta.htm (accessed 18 September 2016) (in Russian).

Kuzina O., Chernysheva M. (2015) Korporativnaya blagotvoritelnost' i otvetstvennost': obosnovanie ponyatiy [Corporate Charity: Foundations of Notions]. Monitoring obshchestvennogo mneniya: ekonomicheskie i sotsialnyie peremenyi, no 4, pp. 154-165 (in Russian).

Kuzina O., Chernysheva M. (2016) Korporativnaya blagotvoritelnost' i korporativnaya filantropiya: ekonomiko-sotsiologicheskiy analiz [Corporate Charity and Corporate Philanthropy in Russia: An Economic Sociology Analysis]. Voprosy ekonomiki, no 3, pp. 115-130 (in Russian).

Lähdesmäki M., Suutari T. (2012) Keeping at Arm's Length or Searching for Social Proximity? Corporate Social Responsibility as a Reciprocal Process Between Small Businesses and the Local Community. Journal of Business Ethics, vol. 108, no 4, pp. 481-493.

Leisinger K. (2007) Corporate Philanthropy: The "Top of the Pyramid". Business and Society Review, vol. 112, no 3, pp. 315-342. 
Longo M., Mura M., Bonoli A. (2005) Corporate Social Responsibility and Corporate Performance: The Case of Italian SMEs. Corporate Governance, no 5, pp. 28-42.

Murillo D., Lozano J. (2006) SMEs and CSR: An Approach to CSR in Their Own Words. Journal of Business Ethics, no 67, pp. 227-240.

O kontraktnoy sisteme $v$ sfere zakupok tovarov, rabot, uslug dlya obespecheniya gosudarstvennyih $i$ munitsipalnyih nuzhd (2013) April 5. 44-FZ [About Contract System in the Procurement of Goods, Works and Services for State and Municipal Needs. Law 44 on April 5, 2013]. Available at: http://base.garant. ru/70353464/ (accessed 17 September 2016) (in Russian).

O predelnyih znacheniyah vyiruchki ot realizatsii tovarov (rabot, uslug) dlya kazhdoy kategorii sub'ektov malogo i srednego predprinimatelstva (2013) February 9. Postanovlenie Pravitelstva RF. No. 101 [On the Limit Values of Revenue from Sale of Goods (Works, Services) for Each Category of Small and MediumSized Businesses. RF Government Resolution on February 9, 2013. No. 101]. Available at: http://base. garant.ru/70313430/ (accessed 18 September 2016) (in Russian).

O predelnyih znacheniyah vyiruchki ot realizatsii tovarov (rabot, uslug) dlya kazhdoy kategorii sub'ektov malogo i srednego predprinimatelstva (2015) July 13. Postanovlenie Pravitelstva RF. No. 702 [On the Limit Values of the Proceeds from the Sale of Goods (Works, Services) for Each Category of Small and Medium-Sized Businesses. RF Government Resolution on July 13, 2015. No. 702]. Available at: http://ivo. garant.ru/\#/document/71134484 (accessed 18 September 2016) (in Russian).

O razvitii malogo i srednego predprinimatelstva v Rossiyskoy Federatsii (2007) July 11. 209-FZ [On the Development of Small and Medium Enterprises in the Russian Federation. Law 209 on July 11, 2007]. Available at: http://ivo.garant.ru/\#/document/12154854 (accessed 18 September 2016) (in Russian).

Oberemko O. (2006) Blagotvoritelnost v moem gorode: analiz perspektiv blagotvoritelnosti v gorodakh Podmoskovya [Charity in My Town: The Analysis of Prospects for the Charity in the Moscow Region Towns], Moscow: Institute of Social and Gender Policy (in Russian)

Oberemko O. (2007) Lokalnaya identichnost blagotvoritelya kak predstavlenie o "territorii svobodyi" [Local Philanthropist Identity as a Representation of the "Area of Freedom"]. Sotsialnaya realnost, vol. 3, no 4, pp. 106-116 (in Russian).

Parsons T. (1964) Evolutionary Universals in Society. American Sociological Review, vol. 29, no 3, pp. 339-357.

Parsons T. (1991) The Social System, London: Routledge.

Peregudov S. (2003) Korporatsii, obschestvo, gosudarstvo: evolyutsiya otnosheniy [Corporation, Society, State: The Evolution of Relations], Moscow: Nauka (in Russian).

Peregudov S. (2006) Krupnaya korporatsiya kak sub'ekt publichnoy politiki [A Large Corporation as the Subject of Public Policy], Moscow: HSE (in Russian).

Peregudov S. (2008) Korporativnoe grazhdanstvo: kontseptsii, mirovaya praktika i rossiyskie realii [Corporate Citizenship: Concepts, World Experience and the Russian Realities], Moscow: Progress-Tradition; Institute of World Economy and Int. Relations (in Russian) 
Perrini R., Russo A., Tencati A. (2007) CSR Strategies of SMEs and Large Firms. Evidence from Italy. Journal of Business Ethics, no 74, pp. 285-300.

Perrini R., Russo A. (2010) Investigating Stakeholder Theory and Social Capital: CSR in Large firms and SMEs. Journal of Business Ethics, vol. 91, no 2, pp. 207-221.

Prasad A., Holzinger I. (2013) Seeing through Smoke and Mirrors: A Critical Analysis of Marketing CSR. Journal of Business Research, vol. 66, no 10, pp. 1915-1921.

Preuss L., Perschke J. (2010) Slipstreaming the Larger Boats: Social Responsibility in Medium-Sized Firms. Journal of Business Ethics, no 92, pp. 531-551.

Quinn J. (1997) Personal Ethics and Business Ethics: The Ethical Attitudes of Owner/Managers of Small Business. Journal of Business Ethics, vol. 16, no 2, pp. 119-127.

Rajak D. (2008) 'Uplift and Empower': The Market, Morality and Corporate Responsibility on South Africa's Platinum Belt. Research in Economic Anthropology, no 28, pp. 297-324.

Roelofs J. (2003) Foundations and Public Policy: The Mask of Pluralism, Albany: SUNY Press.

Russo A., Tencati A. (2009) Formal vs Informal CSR Strategies: Evidence from Italian Micro, Small, Medium-Sized and Large Firms. Journal of Business Ethics, no 85, pp. 339-353.

Shteynberg I.( 2014) Logicheskie shemyi obosnovaniya vyiborki dlya kachestvennyih intervyu: "vosmiokonnaya" model [Logics Chemes of Sampling for Qualitative Interviews: "vosmiokonnaya" Model]. Sotsiologiya: 4M, no 38, pp. 38-71 (in Russian).

Siluanov A., Starodubrovskaya I., Nazarov V. (2011) Metodologicheskie podhodyi k otsenke effektivnosti mezhbyudzhetnyih otnosheniy v sub'ektah Rossiyskoy Federatsii [Methodological Approaches to Assessing the Effectiveness of Inter-Budgetary Relations in the Russian Federation]. Ekonomicheskaya politika, no 1, pp. 5-22.

Snider J., Hill R. P., Martin D. (2003) Corporate Social Responsibility in the 21st Century: A View from the World's Most Successful Firms. Journal of Business Ethics, vol .48, no 2, pp. 175-187.

Spence L.(1999) Does Size Matter: The State of the Art in Small Business Ethics. Business Ethics: A European Review, vol. 8, no 3, pp. 163-174.

Spence L. J. (2007) CSR and Small Business in a European Policy Context: The Five C's of CSR and Small Business Research Agenda. Business and Society Review, no 112, pp. 533-552.

Spence L., Habisch A., Schmidpeter R. (eds) (2004) Responsibility and Social Capital: The World of Small and Medium Sized Enterprises, Houndmills, UK: Palgrave Macmillan.

Spence L. J., Rutherfoord R. (2003) Small Business and Empirical Perspectives in Business Ethics: Editorial. Journal of Business Ethics, vol. 47, no 1, pp. 1-5.

Sundaram A., Inkpen A. (2004) The Corporate Objective Revisited. Organization Science, vol. 15, no 3, pp. $350-363$. 
Taneja S., Taneja P., Gupta R. (2011) Researches in CSR: A Review of Shifting Focus, Paradigms and Methodologies. Journal of Business Ethics, no 101, pp. 343-364.

Tilley F. (2000) Small Firm Environmental Ethics: How Deep Do They Go? Business Ethics: A European Review, vol. 9, no 1, pp. 31-41.

Vázquez-Carrasco R., López-Pérez M. E. (2013) Small \& Medium-Sized Enterprises and Corporate Social Responsibility: A Systematic Review of the Literature. Quality \& Quantity Journal, no 47, pp. 3205-3218.

Vo L. C. (2011) Corporate Social Responsibility and SMEs: A literature Review and Agenda for Future Research. Problems and Perspectives in Management, vol. 9, no 4, pp. 89-97.

Weber M. (1978) Economy and Society, Berkeley, CA: University of California Press.

Received: May 20, 2016.

Citation: Chernysheva M. (2016) Blagotvoritel'nost' malogo i srednego biznesa v malom gorode: empiricheskiy analiz [Charity of Small- \& Medium-Sized Businesses in a Russian Small Town: An Empirical Analysis]. Journal of Economic Sociology = Ekonomicheskaya sotsiologiya, vol. 17, no 4, pp. 129-163. Available at: https://ecsoc.hse.ru/2016-17-4.html (in Russian). 


\title{
ПРОФЕССИОНАЛЬНЫЕ ОБЗОРЫ
}

\author{
Р. И. Романова
}

\section{Успех фрирмы: что это такое, от чего он зависит и как его измерить ${ }^{1}$}

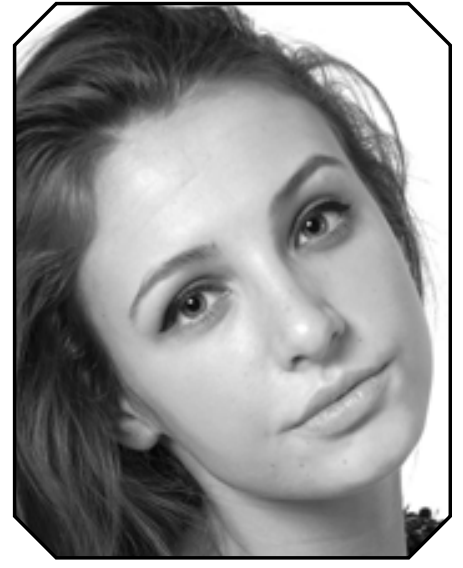

РОМАНОВА Регина Игоревна - аспирант, стажёр-исследователь Лаборатории экономикосоциологических исследований, преподаватель департамента социологии факультета социальных наук Национального исследовательского университета «Высшая школа экономики». Адрес: 101000, Россия, г. Москва, ул. Мясницкая, д. 20.

Email: rromanova@hse.ru
Почему одни компании более успешны, нежели другие? Поиску ответа на этот вопрос посвящены многочисленные исследования в менеджменте, экономической теории и сочиологии. Однако из-за отсутствия универсальной конщептуализации самого понятия и несовпадения методологических предпосылок наблюдаются серьёзные расхождения в объяснении причин успеха. В результате в организационных исследованиях нет консенсуса ни по поводу того, что считать индикатором успеха компании, ни о том, как его измерить. В начале обзора разбираются трудности использования категории «эффективность» (effectiveness) в исследовании поведения фирм, анализируются потенциал и ограничения альтернативного термина - «результативность» (performance). Затем предпринята попытка систематизировать теоретические наработки в области стратегического менеджмента и сочииологической теории организаций. Внимание к стратегическому менеджменту обусловлено тем, что данное ответвление менеджмента фактически сформировалось вокруг вопроса о том, почему одни компании превосходят другие. В отличие от своей интеллектуальной предшественницы - индустриальной экономики, - стратегический менеджмент переносит акцент на деятельность и структуру фирмы как на фактор, обусловливаюший различия в результативности компаний. Рассматриваются два ичентральных конструкта в стратегическом менеджменте - стратегии и ресурсы фирмы. В первом случае речь идёт о теории стратегического выбора (strategic choice) и о теории обстоятельств (contingency theory), а во втором - о доминирующей на текущий момент теории ресурсной зависимости (resource-based view). В отличие от стратегического менеджмента, организационные исследования в социологии объясняют успех компаний, опираясь на внешние факторы, так или иначе анализируя эффект среды. Темы выюивания фирм, их успешной адаптации явно или имплицитно затрагиваются сразу в нескольких аналитических перспективах экономической сочиологии - в сетевом, экологическом и институциональном подходах. В заключение в обзоре обсуждаются методологические сложности изучения результативности компаний, которые требуют от исследователей создания композиционных моделей объяснения успеха фирм, учитывающих синергетический эффрект как внутренних, так и внешних факторов.

Автор выражает благодарность Е. Бердышевой и М. Маркину за их ценные комментарии, а также В. Радаеву за научное руководство. В данной научной работе использованы результаты проекта «Институциональные и структурные основы современных российских рынков», выполненного в рамках Программы фундаментальных исследований НИУ ВШЭ в 2016 г. 
Ключевые слова: результативность; эффективность; ресурсный подход; стратегия; измерение результативности; сетевой подход; экологический подход; институциональный подход; стратегический менеджмент.

\section{Введение}

Вопрос о причинах успеха компаний представляет собой редкий пример темы, одинаково интересной как академическому сообществу, так и практикам. Поиск и объяснение причин преуспевания одних компаний и упадка других признаётся важной исследовательской проблемой в социологии [Fligstein 2001], менеджменте [Тамбовцев 2010] и в экономической теории [Porter 1981]. Однако, несмотря на большой эвристический потенциал темы и её прикладной характер, существует ряд трудностей.

Львиная доля проблем проистекает из одного вопроса: какую компанию можно считать успешной? На первый взгляд ответ на этот вопрос кажется элементарным: компания, которая эффективна, результативна и конкурентоспособна. Дело за малым: нужно лишь понять, что подразумевается под этими категориями. Один из центральных вопросов для менеджмента и экономической теории стал камнем преткновения для теоретиков, обернувшись непрекращающейся дискуссией (см., например: [Venkatraman, Ramanujam 1986; Cameron, Whetten 1994, Brinkerhoff, Kanter 1981]). Парадоксально, но в организационных исследованиях нет консенсуса ни по поводу того, что считать индикатором успеха компании, ни о том, как его измерить. Более того, ряд организационных исследователей и вовсе предлагают воздержаться от использования этих категорий, причисляя их к неэксплицируемым переменным [Hannan, Freeman 1977; March, Sutton 1997].

Кроме этого, наблюдается междисциплинарное обособление и размежевание менеджмента и социологии [Baum, Dobbin 2000], экономической теории и менеджмента [Porter 1981, Barney 1990; Lockett, Thompson 2001]. В итоге в силу теоретико-методологической специфики объекта, являющегося одновременно зависимой и независимой переменной в анализе, мы имеем дело со своего рода категориейфантомом без формализованного определения, но с интуитивно понятным содержанием. Несмотря на долгую традицию изучения успеха, большинство исследований не заботится о теоретическом, а иногда даже и об операциональном осмыслении понятия, которое они хотят объяснить [Miller, Washburn, Glick 2013].

В рамках данного обзора мы сфокусируемся на том, как в разных дисциплинарных полях объясняют причины успеха компаний. В первой части работы постараемся проанализировать сложившийся терминологический аппарат, который используется при концептуализации успеха компании. Затем представим объяснения причин рыночного успеха, сформулированные в рамках стратегического менеджмента и в социологических исследованиях организаций. Внимание к стратегическому менеджменту обусловлено тем, что данное направление фактически сформировалось вокруг вопроса о том, почему одни компании превосходят другие [Meyer 1991]. На основе этого анализа мы предложим возможный вариант концептуализации, учитывающий релевантные индикаторы, и покажем методологические сложности при построении объясняющей модели.

\section{Проблема реконструкции понятий: от эффективности к результативности}

Прежде чем перейти к реконструкции понятий, хотелось бы отметить, что речь идёт исключительно об организациях, ориентированных на получение прибыли, о фирмах. Задача данного раздела - разобраться с терминологическим плюрализмом, характерным для любого междисциплинарного объекта. Для других организационных форм (например, для некоммерческих организаций) существуют отдельные эвристические инструменты анализа эффективности (см. обзор: [Гудова 2016]). 
Для того чтобы наглядно продемонстрировать важность терминологической согласованности, обратимся к конкретному примеру. Хорошо известно, что часто лидирующие компании сознательно мирятся с невысокой рентабельностью продаж, снижая цены своей продукции. Такая тактика позволяет завоевать бо́льшую долю рынка и максимизировать объёмы прибыли в долгосрочной перспективе [Гончар, Кузнецов 2008: 43]. Ограничившись одним критерием финансовой состоятельности компании, мы рискуем неправильно проинтерпретировать положение организации и расстановку сил на рынке в целом.

Начнём наш экскурс с наиболее широкой категории - с эффективности (effectiveness). В общем виде модель эффективности предполагает как минимум три уровня измерения: достижение целей организации; оптимальная организационная структура, поддерживающая функционирование организации; способность адаптироваться к изменениям среды [Brinkerhoff, Kanter 1981: 322]. Дать общепринятое определение эффективности, с которым согласились бы большинство представителей организационных исследований, фактически невозможно. Несмотря на всю аналитическую значимость концепта, некоторые авторы призывают оставить бесплодные попытки оценить неизмеримую эффективность и сосредоточиться на конкретных индикаторах [Kahn 1977; Goodman, Atkin, Schoorman 1983].

Чем продиктованы такие сложности? Во-первых, есть теоретические трудности, обусловленные полимодальностью конструкта «эффективность» [Cameron 1986]. Во-вторых, интерпретация термина тесно связана с методологией его измерения. Необходимо сразу определить, на каком аналитическом уровне и с помощью каких данных мы измеряем эффективность. Известно, что эффективность одних организационных элементов может легко сочетаться с неэффективностью других процессов [Cameron, Whetten 1983].

Использовать такое неоднозначное понятие, как эффективность, при анализе поведения предприятий крайне затруднительно. В качестве альтернативы эффективности применяется более узкий термин «результативность» (performance), отражающий фактический уровень экономического развития компании [Richard et al. 2009]. Несмотря на то что результативность носит менее абстрактный характер, нежели эффективность, проблема многозначности не снимается.

Прежде всего, проясним ключевой момент соотношения понятий, представленный на рисунке 1. Базовым индикатором уровня благосостояния фирмы считается финансовая результативность (financial performance), относящаяся к достижению конкретных экономических целей, таких как доходы, рентабельность активов, рентабельность инвестиций, выручка и др. Операциональная результативность (operational performance) является более широкой категорией, нежели финансовая результативность, и включает технологические показатели работы компании (доля рынка, качество продукции, создание нового продукта и др.), обусловливающие финансовый успех. В качестве объекта исследования обычно используется рыночная результативность (business performance) как комбинация показателей двух типов результативности. Наконец, приведённые типы результативности являются одним из компонентов интегрального понятия эффективности организации.

Исследователи часто пренебрегают сложной операциональной природой термина и ограничиваются лишь одной из приведённых выше характеристик результативности르 [Miller, Washburn, Glick 2013: 956]. Однако, как показывают эмпирические исследования, выделение одного критерия результативности неудачная стратегия [Chakravarthy 1986]. На примере анализа лидирующих и отстающих компаний в компьютерной индустрии Америки Б. Чакраварати статистически показал, что при использовании

2 Стоит отметить, что проблема не только в некритичном подходе к ключевой переменной, но и в ограничениях, накладываемых эмпирическими данными. Особенно в тех случаях, когда речь идёт об организациях, которые не обнародуют свою финансовую отчётность [Dess, Robinson 1984]. 
лишь одной из характеристик результативности никаких явных различий между лидерами и аутсайдерами нет. Чтобы исправить обнаруженный методологический недостаток, исследователь призывает строить композиционные модели, интегрирующие сразу несколько критериев результативности.

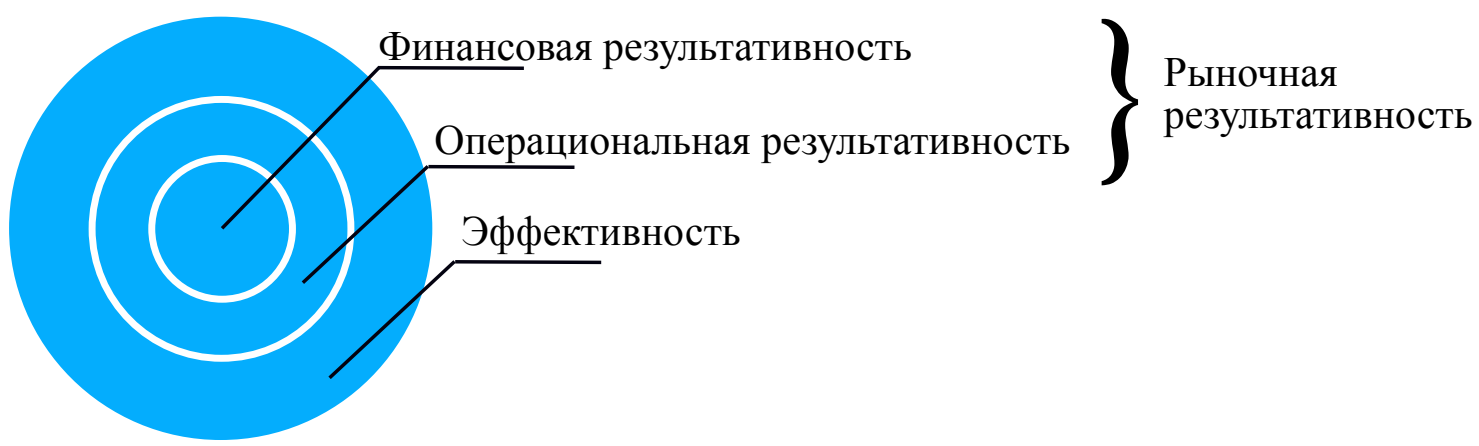

Источник: [Venkatraman, Ramanujam 1986: 803].

Рис. 1. Соотношение понятий «результативность» и «эффективность»

В экономической литературе индикатором результативности считается продуктивность деятельности организации, измеренная через производительность труда, производительность капитала и др. [Гончар, Кузнецов 2008; Федотов 2012]. В менеджериальных исследованиях оперируют термином «конкурентное преимущество» (competitive advantage), которое, в сущности, синонимично результативности [Crook et al. 2008]. Что же касается экономической социологии, то даже на уровне понятийного аппарата категория рыночной эффективности не имеет фиксированной демаркационной границы. В лучшем случае признаётся неоднозначность определения успешности [Levitt, March 1988: 325]; в других ситуациях между выживанием и эффективностью ставится знак равенства [Мейер, Роуэн 2011], а некоторые направления и вовсе занимаются лишь вопросами, связанными с выживанием, отодвигая успешность деятельности на второй план [Хэннан, Фримен 2013].

\section{Предтечи стратегического менеджмента в формировании базовых понятий}

Как отмечалось ранее, стратегический менеджмент - это ответвление дисциплины, приоритетно изучающее источники и условия различий в результативности компаний. Своими интеллектуальными корнями данная дисциплина уходит к организационной экономике [Caves, Porter 1977] и менеджменту [Penrose 1959; Chandler 1962].

Впервые вопросы о том, как компании достигают успеха, решались в рамках индустриальной экономики. Базовая объясняющая модель была сформулирована Э. Мейсоном и Д. Бейном и получила название «Структура, поведение, результативность» (Structure, Conduct and Performance - SCP) [Mason 1939; Bain 1956]. Основанная на предпосылке о совершенной конкуренции и рыночном равновесии, данная парадигма предполагает, что положение компаний зависит от состояния отрасли. Чтобы сохранить своё место на рынке, компания должна придерживаться такой ценовой политики, которая послужит барьером на вход для других продавцов [Bain 1956: 3]. Соответственно конкурентный уровень цен играет решающую роль для участников рынка, сводя их поведение (conduct) к ряду простых решений о количестве и качестве выпускаемой продукции. Однако для объяснения различий в производительности компаний достаточно проанализировать структуру рынка, так как поведение компании является простой реакцией на текущее состояние рынка.

Объяснение различий в доходах компаний в рамках модели SCP имеет серьёзные недостатки. Акцент на структуре рынка оставляет без внимания фирму как таковую. Поведение компании исключительно реактивно, поэтому, в сущности, никаких различий, кроме размера, между фирмами нет [Porter 1981]. Модель 
Бейна-Мейсона была модифицирована в исследованиях М. Портера. В отличие от своих предшественников из индустриальной экономики, он анализирует не только роль барьеров для входа и выхода при заданной структуре отрасли, но и поведение компаний. Согласно этому подходу, прибыльность фирмы зависит от того, насколько эффективно компания смогла отреагировать на конкурентные вызовы - на угрозу вхождения на рынок новых участников, угрозу появления товаров-субститутов, рыночную власть покупателей и поставщиков и соперничество между действующими конкурентами [Портер 2005].

Несмотря на введение понятия «стратегия фирмы», объяснение Портера также сфокусировано на макроуровне работы рыночных механизмов. Такое невнимание к внутреннему устройству фирмы, при котором она остаётся «чёрным ящиком», серьёзный недостаток любого объяснения, выполненного в логике неоклассической экономической теории [Demsetz 1997]. Однако уже в исследованиях А. Чандлера [Chandler 1962], Д. Чайлда [Child 1972] и Э. Пенроуз [Penrose 1959] деятельность и структура фирмы превратилась из вспомогательно-инструментального элемента теории в самодостаточный предмет для изучения. Чандлер, а вслед за ним и Чайлд представили понимание стратегии фирмы, при котором элементы стратегии играют решающую роль в формировании организационной структуры фирмы. Э. Пенроуз, в свою очередь, связала причины роста благосостояния фирм с возможностями эффективно обращаться с ресурсами, которыми та располагает.

Таким образом, мы выделили три ключевых понятия, используемых в стратегическом менеджменте для анализа эффективности фирмы: «структура рынка» (среда), «стратегия» и «ресурсы». В более поздних исследованиях фокус смещается с характеристик среды на фирму, которая перестаёт быть «чёрным ящиком», её характеристики и реакции значимы для ответа на заветный вопрос о том, как достигается рыночный успех. Далее мы рассмотрим два ключевых для нашей темы подхода.

\section{Стратегия: оптимальный выбор или успешная адаптация}

Категория «стратегия», послужившая названием для всего направления, играет центральную роль при объяснении причин успеха фирм. Можно условно выделить два аналитических уровня стратегии: принятие решений внутри организации и линия поведения организации как таковой. В первом случае речь идёт о теории стратегического выбора (strategic choice), которая предполагает, что решение о курсе развития организации принимает актор, обладающий властью [Child 1997]. Во втором - о теории обстоятельств (contingency theory), предполагающей, что чем больше соответствие (fit) характеристик организации внешним обстоятельствам, тем выше результативность [Donaldson 2001]. Иными словами, речь идёт о стратегиях внутри организации в теории стратегического выбора и о внешней стратегии структурного соответствия среде в теории обстоятельств.

Безусловно, в случае с теорией стратегического выбора речь не идёт о полном абстрагировании от эффекта среды. Как утверждает сам Д. Чайлд, теория стратегического выбора должна учитывать как проактивный, так и реактивный способы принятия решений [Child 1997: 53]. С одной стороны, акторы способны брать инициативу в свои руки: вступать в среду, менять её в случае, если она не устраивает, или же адаптироваться к ней. С другой стороны, среда оказывает конституирующее влияние на акторов, задавая приемлемые в представлении участников рынка рамки поведения.

Из этой ветви рассуждений в рамках теории стратегического выбора родилось целое направление демография топ-менеджмента, анализирующая, как характеристики менеджмента компании связаны с принятием рациональных решений при управлении компанией и как это сказывается на результативности компании [Miller, Cardinal 1994]. Однако стоит отметить, что эмпирические исследования не отличаются той теоретической глубиной, которую предполагает в своих рассуждениях Чайлд. В качестве объясняющих переменных используются данные о возрасте, об уровне образования и занимаемой 
позиции в компании. Далее анализируется связь этих характеристик с рациональным принятием решений (которое заключается в ответе на анкетный вопрос о том, какую стратегию развития менеджер считает оптимальной). Затем проверяется наличие связи между рациональным принятием решений, типом бизнес-среды и результативностью компании. Итоговый вывод может быть представлен следующим образом: в условиях благоприятной среды высокий уровень образования топ-менеджеров положительно связан с рациональным стратегированием, что, в свою очередь, позитивно сказывается на результативности компании [Goll, Rasheed 2005].

Несколько иного представления о стратегии как о типе поведения фирмы, а не менеджмента придерживаются сторонники теории обстоятельств. В частности, в конфигурационном подходе, одном из направлений теории обстоятельств, развиваются идеи об ограниченном разнообразии организаций и о наличии нескольких наиболее эффективных и распространённых организационных форм [Meyer, Tsui, Hinings 1993: 1177]. Своё название данное направление получило благодаря выбранной единице анализа - организационной конфигурации, под которой понимается констелляция одновременно присутствующих взаимосвязанных характеристик компании [Ketchen, Thomas, Snow 1993]. По сути, речь идёт о некоторых устойчивых типах устройства и поведения организации. Как и в теории обстоятельств, предполагается, что, сталкиваясь с одними и теми же внешними условиями среды, организации адаптируются, стараясь соответствовать среде и повышать свою результативность. Однако это не приводит к единообразию среди компаний, как предполагается в институциональном подходе [Димаджио, Пауэлл 2010]. Наоборот, организации с разными структурными и стратегическими характеристиками могут быть одинаково результативны. Данный принцип получил название «эквифинальность» [Gresov, Drazin 1997].

Чтобы понять, как принцип эквифинальности реализуется на практике, обратимся к классической классификации Р. Майлза и Ч. Сноу [Miles et al. 1978], выделивших четыре типа, согласно которым стратегии поведения фирм характеризуются следующим образом:

— обороняющиеся (defenders) нацелены на сохранение и укрепление имеющегося положения на рынке;

- разведывающие, или изыскатели (prospectors), ведут себя активно, ищут новые рынки и способы расширения своего присутствия;

- анализирующие (analyzers), балансируют между обороняющимися и разведчиками; такие предприятия нацелены на расширение присутствия на рынке, но относительно безопасными способами;

- pеагирующие (reactors) придерживаются динамичной и нестабильной стратегии, цель которой оперативно реагировать на изменения на рынке.

Эмпирическое исследование Ч. Сноу и Л. Гребиниак [Hrebiniak, Snow 1980] показывает, что обороняющиеся, разведывающие и анализирующие типы демонстрируют сопоставимо высокие показатели результативности, во многом превосходя реагирующие фирмы. Однако данная зависимость не универсальна: комбинации могут корректироваться в зависимости от типа отрасли, размера компаний и характеристик среды [Zahra, Pearce 1990].

В заключение отметим, что концепция эквифинальности во многом близка социологическому взгляду на хозяйственные явления, допускающему разные типы рациональности и эффективности в зависимости от культуры и социальной структуры [Доббин 2004; Флигстин 2007; Дор 2008]. 


\section{Ресурсы фирмы как конкурентное преимущество}

В 1991 г. выходит статья Д. Барни «Ресурсы фирмы как устойчивое конкурентное преимущество», где он развивает представление о фирме как о наборе ресурсов (bundle of resources) [Barney 1991]. С этого момента началось активное развитие одной из самых распространенных на сегодняшний день теоретических рамок в стратегическом менеджменте - ресурсного подхода (resourse-based view). Подавляющее большинство исследовательских вопросов анализируются именно через призму ресурсного подхода [Butler, Priem 2001].

Ресурсы фирмы операционализируются максимально широко, вмещая почти любой аспект деятельности фирмы. Автор концепции относит к ресурсам все материальные и нематериальные активы, способности, организационные процессы, характеристики структуры фирмы, информацию, знания и др. [Barney 1991: 101]. Ресурсы способны обеспечить своего обладателя конкурентным преимуществом, а значит, и высоким уровнем результативности. Однако, чтобы реализовать функцию конкурентного преимущества, ресурсы должны обладать определёнными характеристиками, то есть быть ценными, редкими, незаменимыми и недоступными для имитации. При этом, чтобы стать конкурентным преимуществом, ресурс должен быть одновременно и ценным (то есть вносить свой вклад в эффективность фирмы), и редким. Если ресурс обладает всеми пятью признаками, то можно утверждать, что у компании есть устойчивое конкурентное преимущество.

Что может выступать в качестве ресурса для компании? За свою 25-летнюю историю ресурсный подход вдохновил многих исследователей, занимающихся организационными исследованиями [Barney, Ketchen, Wright 2011]. Привести поэтому системную классификацию типов ресурсов проблематично, но некоторые примеры для наглядности возможны: учитывая то, что имитация со стороны конкурентов рассматривается как посягательство на рыночные позиции компании, ценным ресурсом для компании будет диверсификация и усложнение своих стратегий, трудных для копирования [Rivkin 2000]. Кроме этого, исследователи активно изучают влияние нематериальных ресурсов на преуспевание фирмы: в качестве источника конкурентного преимущества могут выступать организационная культура компании [Barney 1986] и институциональный капитал компании [Oliver 1997].

Таким образом, апологеты ресурсного подхода предлагают исследователям искать объяснение различий в результативности компаний исключительно внутри самих компаний. Каждая компания обладает набором специфических ресурсов, которые она всячески старается скрыть. Можно утверждать, что ресурсная теория фактически игнорирует влияние внешней среды, так как занята изучением микрооснований, дифференцирующих результативность компаний. Такой теоретический задел вступает в конфликт не только с институциональной теорией в социологии, но и со схожими с ней теориями стратегического выбора и теории обстоятельств. Отрешившись от структуры отрасли, ресурсный подход вступает в противостояние даже с подходом Ч. Портера, хотя оба направления исходят из неоклассических микроэкономических предпосылок.

\section{Социологический взгляд на эффективность компаний}

Проблема объяснения причин, обусловливающих различие в успехах компаний на рынке, очень редко напрямую встаёт перед экономической социологией. Социологическую и экономико-менеджериальную исследовательские традиции отличают друг от друга аналитическая оптика и угол обзора. Социология исходит из методологического императива о необходимости объяснять экономические действия только с поправкой на социальный контекст их формирования. Так, например, исследователя, занимающегося стратегическим менеджментом, интересует, почему при заданных характеристиках фирмы и отрасли одна компания демонстрирует высокие темпы прироста прибыли, а другая - нет [Baum, Dobbin 2000]. 
При аналогичном запросе социолог, скорее, сфокусируется на том, как при заданных исторических и культурных условиях сложились обстоятельства, при которых одна стратегия признается эффективной, а другая - нет [Доббин 2016].

Организационные исследования в социологии предполагают более сложную природу причин выживания и упадка компаний, подвергая сомнению объективность и однозначность каузальных связей в экономической теории [Fligstein 2001: 5]. Фокус на выживании организаций и их успешной адаптации явно или имплицитно затрагивается сразу в нескольких аналитических перспективах экономической социологии, а именно в сетевом, экологическом и институциональном подходах. Остановимся кратко на наиболее значимых для нашей работы теоретических положениях, позволяющих более комплексно взглянуть на причины и условия успешной деятельности фирм.

\section{Сетевой подход: когда связи имеют значение}

В экономической теории наличие социальных отношений между контрагентами рассматривается, скоpeе, как недостаток, так как атомизированный обмен позволяет компаниям делать объективный выбор на основе экономических показателей. Предполагается, что отношения с фиксированным кругом поставщиков и покупателей ставит компанию в невыгодное положение: такая ситуация ослабляет стимулы к развитию конкуренции и создаёт препятствия для эффективной реорганизации предприятий [Кузнецов 2010: 29].

Сетевой подход основывается на посылке об укоренённости экономического действия в социальной структуре [Грановеттер 2002]. Применительно к нашей теме он предлагает следующее объяснение: положение компании в сети напрямую определяет её шансы на возможность получения необходимых для выживания и преуспевания ресурсов [Uzzi 1997: 373]. При этом под ресурсами может пониматься не только финансово-материальная помощь, но и многое другое - организационные практики, продуктивные реакции на изменения среды и проч. Сетевые партнёры становятся залогом безопасной и успешной деятельности, что напрямую сказывается на экономической эффективности, а значит, и на успешности компании [Uzzi 1999; Уцци 2007].

Определяющее значение в этой ситуации имеют две характеристики: конфигурация сети и характер связей её участников. Так, полностью закрытая сеть, по каналам которой циркулирует одна и та же информация, скорее всего, окажется не самой выгодной структурой. Обеспечивая доверие и солидарность участников, закрытая сеть ограничивает приток внешних идей. Оптимальной стратегией поэтому, как правило, считается наличие структурных пустот [Burt 2004] или структурных складок [Ведреш, Старк 2010]. Включение в сеть внешних агентов, имеющих опосредованную связь с искомой сетью, позволяет добиться притока новых идей и ресурсов, а значит, и повысить эффективность.

Стоит отметить, что сетевой подход в социологии, пожалуй, единственный из рассмотренных нами, в рамках которого ставится прямой вопрос о влиянии на результативность компаний. Так, например, успешные фирмы в лёгкой промышленности отличает стратегия диверсификации портфолио поставщиков и покупателей: при одновременном расшатывании крепких связей фирмы-лидеры отличает интенция на формирование долгосрочных отношений с избранными контрагентами [Gereffi, Frederick 2010: 181]. Также положительное влияние на результативность компании может оказывать наличие переплетённого директората в структуре бизнес-групп [Mizruchi 1996; Keister 1998]. Хотя стоит оговориться, что связи между советами директоров разных компаний не являются универсальным секретом успеха: некоторые эмпирические исследования не подтверждают линейной связи (см. подробнее обзор: [Carney et al. 2011]). Ещё одним сетевым фактором успеха компаний считаются связи с международными партнёрами [Lavie, Miller 2008; Голикова, Гончар, Кузнецов 2012]. Менеджеры ком- 
паний стараются интериоризировать кажущиеся им успешными практики и рутины, обеспечивая тем самым конкурентное преимущество на локальном рынке.

Как показывают эмпирические исследования, для успешной деятельности фирмы важны не только связи с контрагентами в рамках отрасли, но и устойчивые контакты с государственными структурами. Например, в случае с Китаем установление устойчивых отношений менеджеров компаний с госслужащими позволяет компаниям расширить свою долю на рынке и стать более рентабельными [Peng, Luo 2000]. Схожие эффекты прослеживаются и в российских реалиях: эффективность бизнеса в большой степени зависит от наличия доступа к властному ресурсу и интеграции с государством с целью получения преференций [Яковлев 2005].

Справедливости ради стоит отметить, что экономический потенциал надёжного партнёрства был до определённой степени оценён в теории трансакционных издержек, аргументация которой воспроизводится и в стратегическом менеджменте [Уильямсон 1996]. Возвращаясь к логике ресурсного подхода, мы можем говорить о сетевых связях как о ценном ресурсе для компании, позволяющем достичь конкурентного преимущества [Barney, Hansen 1994]. Значимость взаимодействия между партнёрами и возрастающая роль доверия признаются эффективными лишь на уровне диадических связей. Все отношения за пределами контрактных обязательств рассматриваются как площадка для оппортунистического поведения. Самой же структуре социальных отношений, в которых разворачивается хозяйственная деятельность, отводится скромная роль внешней рамки, не участвующей в анализе [Уцци 2007: 47].

\section{Экологический подход и акцент на выживание}

Следует оговориться, что от любых абсолютных категорий («эффективность», «успех», «результативность») основоположники экологического подхода М. Хэннан и Дж. Фримен отказались сразу. Их концепция терминологически отличается от теорий, рассмотренных нами ранее. Вместо понятий «эффективность» и «результативность» они оперируют демографическими показателями смертности (mortality rate), рождаемости (founding rates) или же биологического выживания (survival).

Согласно экологическому подходу, организации подвержены структурной инерции, то есть изменения в среде крайне редко сопровождаются изменениями в устройстве компании [Хэннан, Фримен 2013]. Парадоксально, но при этом ригидность организационных структур рассматривается как положительное явление. Побочным продуктом инерции становятся надёжность (reliability) и контролируемость (accountability) деятельности организации, что особенно важно для потребителей и внешних наблюдателей [Carroll, Khessina 2005: 457]. Организация, сохраняя ядро рутинных деловых практик и технологий, способна двигаться по уже освоенной колее, занимаясь воспроизводством устоявшихся бизнесстратегий. Конечно, инерция может сыграть и пагубную роль, однако это происходит лишь в случае кардинальных перемен. Так, старые компании зачастую попадают в ловушку компетенций (competence trap): компании, которая была успешной в молодости, сложно изменить рутинные практики, доказавшие свои эффективность, в старости [Le Mens, Hannan, Pólos 2011a]. Если внешние условия отличаются от привычного состояния среды, организация вынуждена трансформировать ключевые элементы структуры, тем самым снижая свои шансы на выживание и адаптацию.

Ещё одной значимой характеристикой, определяющей жизненные шансы организации, является возраст. Поскольку все организации подвержены влиянию внешней среды, с возрастом в них происходят структурные изменения. Исследователи не раз предпринимали попытки по изучению зависимостей между возрастом организации и её жизненной траекторией [Barron, West, Hannan 1994]. Изначально популярностью пользовался принцип «уязвимости нового», согласно которому чем «младше» организация, тем меньше её шансы на выживание [March, Stinchcombe 1965]. С возрастом же, наращивая 
организационные компетенции, компания становится более приспособленной к среде, что снижает риски для её «жизни».

Однако ряд эмпирических исследований доказал, что связь между возрастом и выживанием не носит линейный характер [Le Mens, Hannan, Pólos 2011b]. Дебаты о том, когда именно — в старости, в молодости или же в среднем возрасте - организация более склонна к упадку, ведутся до сих пор. В последнее время в качестве объясняющего элемента выступает не фактический возраст, а так называемый организационный капитал (organizational capital), под которым понимается запас организационных ресурсов. Данная характеристика активируется в зависимости от конкурентного уровня среды. В итоге могут иметь место следующие закономерности: в условиях низкой конкуренции будет действовать правило «уязвимости нового»; в условиях же высокой конкуренции - правило «уязвимости юности» или «уязвимости старости».

С опорой на институциональный подход в социологии представители популяционной экологии говорят о взаимосвязи между выживанием организаций и плотностью занимаемой ниши. Парадоксально на первый взгляд, но чем меньше компаний в нише, тем выше показатели смертности компаний [Hannan, Carroll 1992]. В качестве объяснения авторы обращаются к категории, заимствованной из институционального анализа, - к легитимности. Новая организационная популяция испытывает дефицит социополитической легитимности и низкий уровень доверия. Устоявшаяся же популяция, наоборот, обладает высокой социополитической легитимностью и высоким уровнем доверия.

В завершение описания этого подхода рассмотрим ещё один важный фактор организационного выживания - зависимость между моделями разделения ресурсов (resource-partitioning theory) и размером организации. Для сформировавшихся организационных популяций справедлива следующая закономерность: доминирующее положение нескольких больших компаний и одновременное распространение небольших фирм-специалистов [Carroll, Khessina 2005: 464]. К компаниям-специалистам относятся те, которые используют гомогенные ресурсы и нацелены на узкий рыночный сегмент. Компании, придерживающиеся противоположной стратегии, то есть «универсалы», располагают гетерогенным набором ресурсов и ориентируются сразу на широкий круг рыночных сегментов.

На основе эмпирических данных выделяется универсальная зависимость между эксплуатируемой стратегией (универсальность или специализация) и выживанием. Так, в популяциях с высокой плотностью приоритетное положение остаётся за крупными компаниями-универсалами. Со временем эти компании выталкивают более слабых конкурентов-универсалов, открывая тем самым поле возможностей для небольших компаний, специализирующихся на узком сегменте рынка. В итоге, при прочих равных, в популяции остаются эти два вида компаний, компенсирующих недостатки друг друга и не претендующих на рокировку позиций.

\section{Институциональный подход: эффективность конформизма}

В случае с институциональным направлением исследовательский акцент смещается с того, как реагировать на среду, на то, в какой степени организация зависит от среды и как формируется под её воздействием.

В программной для данного подхода статье Дж. Мейера и Б. Роуэна [2011] утверждается, что залогом выживания организации в современном обществе становится умение поддерживать свою легитимность в глазах окружающих. Легитимность же достигается включением в свою структуру институционализированных практик и рутин, которые функционируют как рационализированные представления о деятельности организации или как мифы и церемониалы. При этом стремление к конформности 
со средой способно приводить к копированию не самых эффективных практик, что, впрочем, может быть компенсировано пользой от легитимности, стабильности и предсказуемости положения организации. Стабильность же играет на руку организации, если удаётся сформировать рутинные практики (routines), отвечающие целям организации и одновременно снижающие издержки поиска и оценки [Zucker 1987: 446].

Организация добывает себе легитимность тремя способами: (1) адаптируясь к культурным ожиданиям, (не)формальным политическим требованиям (принудительный изоморфизм); (2) имитируя успешные образцы организационной структуры в условиях неопределённости (подражательный изоморфизм) и (3) подражая нормативным требованиям, связанным с профессионализацией (нормативный изоморфизм). При этом организации могут комбинировать эти механизмы «укрощения» среды [Димаджио, Пауэлл 2010].

Тем не менее институциональный подход испытывает серьёзные сложности при необходимости объяснить организационные изменения или то, почему одни и те же условия среды порождают разные типы организаций [Hinings, Malhotra 2008]. Здесь как нельзя кстати приходятся теоретические импликации из теории обстоятельств и теории стратегического выбора. Так, Й. Беккерт предлагает инкорпорировать теорию стратегического выбора, чтобы сделать институциональный подход более динамичным и чутким к изменениям в среде [Beckert 1999]. Для этого в институциональный анализ необходимо ввести понятие «институциональный предприниматель» (institutional entrepreneur), то есть актор, pacполагающий достаточными ресурсами, чтобы изменить правила игры с учётом своих интересов. Институциональный предприниматель действует согласно шумпеттеровской логике созидательного разрушения: отказывается от общепризнанных правил (taken-for-granted rules) и переключается на другие образцы, если сочтет их более выгодными в текущих условиях. Что же касается организационного разнообразия, то необходимое объяснение обнаруживается в рамках конфигурационного подхода, предполагающего, что точка оптимума может быть достигнута разными структурными и стратегическими характеристиками организаций [Gresov, Drazin 1997].

\section{Методологические вызовы:}

\section{зачем нужна интегральная модель объяснения успеха?}

В силу специфики объекта тема объяснения результативности компаний так или иначе освещается сразу в нескольких дисциплинарных направлениях. В одних случаях факт взаимосвязи исследовательских посылок рассматривается как необходимая и продуктивная стратегия для комплексного анализа [Aldrich, Ruef 2006: 36]. В других же подчёркивается невозможность компиляции аналитических традиций и настоятельно акцентируется приоритетное положение собственной теоретической перспективы [Uzzi 1997; Barney 2001; Swedberg 2005]. Построение композиционной модели, синтезирующей идеи разных подходов, нам представляется не просто продуктивным, но необходимым условием для объяснения причин и факторов достижения успеха.

Нельзя предварительно назвать приоритетное направление и выбрать один наиболее существенный фактор успеха. Едва ли можно сказать, что отдельный индикатор (например, сетевые связи компании или организационная культура) является единственным источником успеха компании. Так, в одном случае благоприятная внешняя конъюнктура может привести компанию к успеху, обеспечив её конкурентоспособность независимо от качества менеджмента или организационной структуры. В другом же случае, даже несмотря на враждебность бизнес-среды, талант и качество менеджмента обеспечат устойчивое положение компании на рынке. Конечно, это полярные примеры, необходимые для более яркой иллюстрации идеи, однако именно из-за многообразия сценариев успешного развития стоит сконструировать более всестороннюю схему анализа. 
Что является достаточным, а что необходимым условием достижения высокой результативности? Можно ли определить и оценить синергетический эффект отдельных элементов? Методологическим решением этой проблемы активно занимаются организационные исследователи [Fiss, Cambré, Marx 2013]. Компромиссное решение сводится к тому, чтобы включать в анализ предикторы разных уровней, допуская как влияние сверху вниз (bottom-up) и снизу вверх (top-down), так и компиляцию факторов обоих уровней [Klein, Kozlowski 2000; Rousseau, Fried 2001; Whetten 2009].

Нельзя игнорировать тот факт, что успех - не статичное состояние, но продукт долгосрочных изменений. Успех не может быть измерен дискретно, необходимо брать в расчёт временную перспективу. Важной нормирующей характеристикой анализа выступает категория «время», под которой понимается не столько количественная метрика, фиксирующая дни, месяцы, годы, сколько содержательная категория. Социально сконструированное время (socially constructed time) отражает периоды, значимые для актора, определившие логику развития организации [Aldrich 2009: 31]. При этом данная категория может быть смоделирована как на микроуровне, так и на макроуровне. В первом случае речь идёт о жизненном курсе одной организации, её индивидуальной истории (например, важным этапом для компании могут стать период реорганизации управления и смена власти в компании, задавшие вектор перемен). На макроуровне время определяется ключевыми переменами для организационного поля в целом, повлиявшими на всех игроков сразу (например, законодательные изменения или геополитическая ситуация).

\section{Заключение: чем социология полезна для изучения успешных компаний?}

Основная сложность с операционализацией понятия «успех» заключается в том, что это субъективная категория; многозначность толкований термина определяется многообразием контекстов его использования. Кроме того, есть серьёзные методологические трудности измерения данной категории. Современные организации представляют собой комплексные динамичные системы. Во всём многообразии структурных элементов крайне затруднительно выделить наиболее значимый. Кроме этого, важность тех или иных характеристик организации (успех в их числе) меняется, отражая доминирующие в обществе ценности в конкретный период. Например, сейчас в большинстве случаев критерием успеха компании считается уровень капитализации компании. При этом рост производительности компании, казалось бы, ключевая характеристика экономического предприятия в прошлом столетии, отходит на периферию, уступая место планам по слияниям и поглощениям. Иными словами, с наступлением информационной революции ценность производства как такового «проигрывает» ценности форсированного роста активов. А значит, одна модель успеха уступила место другой. Как и любой артефакт экономической деятельности, эффективность можно и нужно рассматривать как продукт социального конструирования. Социология предлагает более широкую аналитическую рамку, которая позволит преодолеть узконаправленный взгляд теоретиков стратегического менеджмента, скованный необходимостью формулировать практические рекомендации для бизнес-сообщества здесь и сейчас.

\section{Литература}

Ведреш Б., Старк Д. 2010. Структурные складки: продуктивный разрыв в пересекающихся группах. Экономическая социология. 11 (4): 69-104. URL: https://ecsoc.hse.ru/2010-11-4.html

Голикова В., Гончар К., Кузнецов Б. 2012. Влияние экспортной деятельности на технологические и управленческие инновации российских фирм. Российский журнал менеджмента. 10 (1): 3-18. URL: http://www.rjm.ru/en/archive/list/t_10_1_2012_g/ 
Гончар К., Кузнецов Б. (ред.). 2008. Российская промышленность на этапе роста: факторы конкурентоспособности фирм. М.: Вершина.

Грановеттер М. 2002. Экономическое действие и социальная структура: проблема укоренённости. Экономическая соииология. 3 (3): 44-58. URL: https://ecsoc.hse.ru/2002-3-3.html

Гудова Е. 2016. Эффективность с «человеческим лицом»: эволюция понимания эффективности в теории организаций. Мониторинг общественного мнения: экономические и сочииальные перемены. 131 (1): 231-239.

Димаджио П., Пауэлл У. 2010. Новый взгляд на «железную клетку»: институциональный изоморфизм и коллективная рациональность в организационных полях Экономическая социология. 11 (1): 34-56. URL: https://ecsoc.hse.ru/2010-11-1.html

Доббин Ф. 2004. Политическая культура и индустриальная рациональность. Экономическая соииология. 5 (1): 43-60. URL: https://ecsoc.hse.ru/2004-5-1.html

Доббин Ф. 2016. Сравнительный и исторический подходы в экономической социологии. Экономическая соииология. 17 (3): 37-81. URL: https://ecsoc.hse.ru/2016-17-3.html

Дор Р. 2008. Различия японской и англо-саксонской моделей капитализма. Экономическая соииология. 9 (1): 65-78. URL: https://ecsoc.hse.ru/2008-9-1.html

Мейер Д., Роуэн Б. 2011. Институционализированные организации: формальная структура как миф и церемониал. Экономическая сочиология. 12 (1): 43-67. URL: https://ecsoc.hse.ru/2011-12-1.html

Кузнецов Б. (ред.) 2010. Предприятия и рынки в 2005-2009 годах: итоги двух раундов обследования российской обрабатывающей промылиленности. М.: Изд. дом ВШЭ.

Портер М. 2005. Конкурентная стратегия: Методика анализа отраслей и конкурентов. М.: Альпина Бизнес Букс.

Тамбовцев В. Л. 2010. Стратегическая теория фирмы: состояние и возможное развитие. Российский журнал менеджмента. 8 (1): 5-40. URL: http://www.rjm.ru/en/archive/list/t_v_8_n_1_2010_g/

Уильямсон О. 1996. Экономические институты капитализма. СПб.: Лениздат.

Уцци Б. 2007. Источники и последствия укоренённости для экономической эффективности организаций: влияние сетей. Экономическая социология. 8 (3): 43-59; 8 (4): 44-60. URL: https://ecsoc.hse. ru/2007-8-3.html и https://ecsoc.hse.ru/2007-8-4.html

Федотов Ю. В. 2012. Измерение эффективности деятельности организации: особенности метода DEA. Российский журнал менеджмента. 10 (2): 51-62. URL: http://www.rjm.ru/en/archive/list/ t_10_2_2012_g/

Флигстин Н. 2007. Государство, рынки и экономический рост. Экономическая сощиология. 8 (2): 41-59. URL: https://ecsoc.hse.ru/2007-8-2.html

Хэннан М. Т., Фримен Д. 2013. Популяционная экология организаций. Экономическая сочиология. 14 (2): 42-72. URL: https://ecsoc.hse.ru/2013-14-2.html 
Яковлев А. А. 2005. Эволюция стратегий взаимодействия бизнеса и власти в российской экономике. Российский журнал менеджмента. 3 (1): 27-52. URL: http://www.rjm.ru/en/archive/list/t_3_1_2005_g/

Aldrich H. 2009. Lost in Space, Out of Time: How and Why We Should Study Organizations Comparatively In: Lounsbury M. (ed.) Studying Differences between Organizations: Comparative Approaches to Organizational Research. Vol. 26. Bingley: Emerald Group Publishing; 21-44.

Aldrich H., Ruef M. 2006. Organizations Evolving. London: SAGE.

Bain J. 1956. Barriers to New Competition. Cambridge: Harvard University Press.

Barney J. B. 1986. Organizational Culture: Can It be a Source of Sustained Competitive Advantage? Academy of Management Review. 11 (3): 656-665.

Barney J. B. 1990. The Debate between Traditional Management Theory and Organizational Economics: Substantive Differences or Intergroup Conflict? Academy of Management Review. 15 (3): 382-393.

Barney J. 1991. Firm Resources and Sustained Competitive Advantage. Journal of Management. 17 (1): 99 120.

Barney J. B. 2001. Resource-Based Theories of Competitive Advantage: A Ten-Year Retrospective on the Resource-Based View. Journal of Management. 27 (6): 643-650.

Barney J. B., Hansen M. H. 1994. Trustworthiness as a Source of Competitive Advantage. Strategic Management Journal. 15 (S1): 175-190.

Barney J. B., Ketchen D. J., Wright M. 2011. The Future of Resource-Based Theory: Revitalization or Decline?. Journal of Management. 37 (5): 1299-1315.

Barron D. N., West E., Hannan M. T. 1994. A Time to Grow and a Time to Die: Growth and Mortality of Credit Unions in New York City, 1914-1990. American Journal of Sociology. 100 (2): 381-421.

Baum J. A., Dobbin F. 2000. Doing Interdisciplinary Research in Strategic Management —Without a Paradigm War. In: Baum J. A., Dobbin F. (eds) Economics Meets Sociology in Strategic Management. Vol. 17. Bingley: Emerald Group Publishing; 389-410.

Beckert J. 1999. Agency, Entrepreneurs, and Institutional Change. The Role of Strategic Choice and Institutionalized Practices in Organizations. Organization Studies. 20 (5): 777-799.

Brinkerhoff D., Kanter R. M. 1981. Organizational Performance: Recent Developments in Measurement. Annual Review of Sociology. 7: 321-349.

Burt R. S. 2004. Structural Holes and Good Ideas. American Journal of Sociology. 110 (2): 349-399.

Butler J., Priem R. L. E. 2001. Is the Resource-Based "View" a Useful Perspective for Strategic Management Research? Academy of Management Review. 26 (1): 22-40.

Cameron K. S. 1986. Effectiveness as Paradox: Consensus and Conflict in Conceptions of Organizational Effectiveness. Management Science. 32 (5): 539-553. 
Cameron K. S., Whetten D. A. 1983. Organizational Effectiveness: One Model or Several? In: Cameron K. S., Whetten D. A. (eds) Organizational Effectiveness: A Comparison of Multiple Models. New York: Academic Press, Inc; $1-24$.

Cameron K. S., Whetten D. A. 1994. Organizational Effectiveness: Old Models and New Constructs. In: Greenberg J. (ed.) Organizational Behavior: The State of the Science. Mahwah, NJ: Lawrence Erlbaum Associates; 135-155.

Carney M. et al. 2011. Business Group Affiliation, Performance, Context, and Strategy: A Meta-Analysis. Academy of Management Journal. 54 (3): 437-460.

Carroll G. R., Khessina O. M. 2005. Organizational and Corporate Demography. In: Poston D., Micklin M. (eds) Handbook of Population. New York: Kluwer Academic/Plenum Publisher; 451-477.

Caves R. E., Porter M. E. 1977. From Entry Barriers to Mobility Barriers: Conjectural Decisions and Contrived Deterrence to New Competition. The Quarterly Journal of Economics. 91 (2): 241-261.

Chakravarthy B. S. 1986. Measuring Strategic Performance. Strategic Management Journal. 7 (5): 437-458.

Chandler A. D. 1962. Strategy and Structure: Chapters in the History of the American Enterprise. Cambridge: Massachusetts Institute of Technology Press.

Child J. 1972. Organizational Structure, Environment and Performance: The Role of Strategic Choice. Sociology. 6 (1): 1-22.

Child J. 1997. Strategic Choice in the Analysis of Action, Structure, Organizations and Environment: Retrospect and Prospect. Organization Studies. 18 (1): 43-76.

Crook T. R. et al. 2008. Strategic Resources and Performance: A Meta-Analysis. Strategic Management Journal. 29 (11): 1141-1154.

Demsetz H. 1997. The Firm in Economic Theory: A Quiet Revolution. The American Economic Review. 87 (2): 426-429.

Dess G. G., Robinson R. B. 1984. Measuring Organizational Performance in the Absence of Objective Measures: The Case of the Privately-Held Firm and Conglomerate Business Unit. Strategic Management Journal. 5 (3): 265-273.

Donaldson L. 2001. The Contingency Theory of Organizations. Thousand Oaks: SAGE Publications.

Fiss P., Cambré B., Marx A. 2013. Configurational Theory and Methods in Organizational Research: Introduction. In: Fiss P., Cambré B., Marx A. (eds). Configurational Theory and Methods in Organizational. Vol. 38. Bingley: Emerald Group Publishing; 1-23.

Fligstein N. 2001. Organizations: Theoretical Debates and the Scope of Organizational Theory. Department of Sociology, University of California Berkley. URL: http://sociology.berkeley.edu/sites/default/files/faculty/ fligstein/inter.handbook.paper.pdf 
Gereffi G., Frederick S. 2010. The Global Apparel Value Chain, Trade and the Crisis: Challenges and Opportunities for Developing Countries. In: Gereffi G., Staritz C., Cattaneo O. (eds) Global Value Chains in a Postcrisis World: A Development Perspective. Washington: World Bank Publications; 157-209

Goll I., Rasheed A. A. 2005. The Relationships between Top Management Demographic Characteristics, Rational Decision Making, Environmental Munificence, and Firm Performance. Organization Studies. 26 (7): 999-1023.

Goodman P. S., Atkin R. S., Schoorman F. D. 1983. On the Demise of Organizational Effectiveness Studies. In: Cameron K. S., Whetten D. A. (eds) Organizational Effectiveness: A Comparison of Multiple Models. New York: Academic Press; 163-183.

Gresov C., Drazin R. 1997. Equifinality: Functional Equivalence in Organization Design. The Academy of Management Review. 22 (2): 403-428.

Hannan M. T., Freeman J. 1977. The Population Ecology of Organizations. American Journal of Sociology. 82 (5): 929-964.

Hannan M. T., Carroll G. 1992. Dynamics of Organizational Populations: Density, Legitimation, and Competition. New York: Oxford University Press.

Hinings C., Malhotra N. 2008. Change in Institutional Fields. In: Beck N., Ebner A. (eds) The Institutions of the Market: Organizations, Social Systems and Governance. New York: Oxford University Press; 106-128

Hrebiniak L., Snow C. 1980. Strategy, Distinctive Competence, and Organizational Performance. Administrative Science Quarterly. 25 (2): 317-336.

Kahn R. L. 1977. Organizational Effectiveness: An Overview. In: Goodman P. S., Pennings J. M. (eds) New Perspectives on Organizational Effectiveness. San Francisco: Jossey-Bass Publishers; 235-248.

Keister L. A. 1998. Engineering Growth: Business Group Structure and Firm Performance in China's Transition Economy. American Journal of Sociology. 104 (2): 404-440.

Ketchen D. J., Thomas J. B., Snow C. C. 1993. Organizational Configurations and Performance: A Comparison of Theoretical Approaches. Academy of Management Journal. 36 (6): 1278-1313.

Klein K., Kozlowski S. 2000. A Multilevel Approach to Theory and Research in Organizations: Contextual, Temporal, and Emergent Processes. In: Kozlowski S., Klein K. (eds) Multilevel Theory, Research, and Methods in Organizations: Foundations, Extensions, and New Directions. San Francisco: Jossey-Bass; 3-90.

Lavie D., Miller S. R. 2008. Alliance Portfolio Internationalization and Firm Performance. Organization Science. 19 (4): 623-646.

Le Mens G., Hannan M. T., Pólos L. 2011a. Drifting Tastes, Inertia, and Organizational Viability. Research Paper. 2082. December. Stanford, USA: Stanford Graduate School of Business. URL: http://papers.ssrn. com/sol3/papers.cfm?abstract_id=1912116.

Le Mens G., Hannan M. T., Pólos L. 2011b. Founding Conditions, Learning, and Organizational Life Chances: Age Dependence Revisited. Administrative Science Quarterly. 56 (1): 95-126. 
Levitt B., March J. G. 1988. Organizational Learning. Annual Review of Sociology. 14: 319-340.

Lockett A., Thompson S. 2001. The Resource-Based View and Economics. Journal of Management. 27 (6): 723-754.

March J. G., Stinchcombe A. L. 1965. Social Structure and Organizations. Advances in Strategic Management. 17: 229-259.

March J. G., Sutton R. I. 1997. Crossroads-Organizational Performance as a Dependent Variable. Organization Science. 8 (6): 698-706.

Mason E. S. 1939. Price and Production Policies of Large-Scale Enterprise. American Economic Review. 29: $61-74$.

Meyer A. D. 1991. What is Strategy's Distinctive Competence? Journal of Management. 17 (4): 821-833.

Meyer A. D., Tsui A. S., Hinings C. R. 1993. Configurational Approaches to Organizational Analysis. Academy of Management Journal. 36 (6): 1175-1195.

Miles R. E. et al. 1978. Organizational Strategy, Structure, and Process. Academy of Management Review. 3 (3): 546-562.

Miller C. C., Cardinal L. B. 1994. Strategic Planning and Firm Performance: A Synthesis of More than Two Decades of Research. Academy of Management Journal. 37 (6): 1649-1665.

Miller C. C., Washburn N. T., Glick W. H. 2013. Perspective - The Myth of Firm Performance. Organization Science. 24 (3): 948-964.

Mizruchi M. S. 1996. What do Interlocks Do? An Analysis, Critique, and Assessment of Research on Interlocking Directorates. Annual Review of Sociology. 22: 271-298.

Oliver C. 1997. Sustainable Competitive Advantage: Combining Institutional and Resource-Based Views. Strategic Management Journal. 18 (9): 697-713.

Peng M. W., Luo Y. 2000. Managerial Ties and Firm Performance in a Transition Economy: The Nature of a Micro-Macro Link. Academy of Management Journal. 43 (3): 486-501.

Penrose E. 1959. The Theory of the Firm. New York: John Wiley \& Sons.

Porter M. E. 1981. The Contributions of Industrial Organization to Strategic Management. Academy of Management Review. 6 (4): 609-620.

Richard P. J. et al. 2009. Measuring Organizational Performance: Towards Methodological Best Practice. Journal of Management. 35 (3): 719-804.

Rivkin J. W. 2000. Imitation of Complex Strategies. Management Science. 46 (6): 824-844.

Rousseau D. M., Fried Y. 2001. Location, Location, Location: Contextualizing Organizational Research. Journal of Organizational Behavior. 22 (1): 1-13. 
Swedberg R. 2005. Economic Versus Sociological Approaches to Organization Theory. In: Knudsen C., Tsoukas H. (eds) The Oxford Handbook of Organization Theory. New York: Oxford University Press; 373-392.

Uzzi B. 1997. Towards a Network Perspective on Organizational Decline. International Journal of Sociology and Social Policy. 17 (7/8): 111-155.

Uzzi B. 1999. Embeddedness in the Making of Financial Capital: How Social Relations and Networks Benefit Firms Seeking Financing. American Sociological Review. 64 (4): 481-505.

Venkatraman N., Ramanujam V. 1986. Measurement of Business Performance in Strategy Research: A Comparison of Approaches. Academy of Management Review. 11 (4): 801-814.

Whetten D. A. 2009. Organizational Comparative Analysis: Investigating Similarities and Differences among Organizations. In: King B. G., Felin T., Whetten D. A. (eds) Studying Differences between Organizations: Comparative Approaches to Organizational Research. Vol. 26. Bingley: Emerald Group Publishing; 6387.

Zahra S. A., Pearce J. A. 1990. Research Evidence on the Miles - Snow Typology. Journal of Management. 16 (4): 751-768.

Zucker L. G. 1987. Institutional Theories of Organization. Annual Review of Sociology. 13: 443-464. 


\title{
Regina Romanova
}

\section{Firm Performance: How to Define it, What Affects it and How to Deal with Measurement Challenges}

\author{
ROMANOVA, Regina - PhD \\ Student, Research Assistant, \\ Laboratory for Studies in \\ Economic Sociology; Lecturer, \\ Department of Sociology, National \\ Research University Higher \\ School of Economics. Address: \\ 20 Myasnitskaya str., Moscow, \\ 101000, Russian Federation.
}

Email: rromanova@hse.ru

\begin{abstract}
How do some firms achieve superior performance and others fail? Much research has been devoted to this question in management, economic theory, and sociology. Nevertheless, due to the absence of a universal approach for conceptualizing firm success and differences in methodological assumptions, numerous studies have produced divergent findings. This has led to continuous debates on the meaning of market success, performance indicators, and measurement techniques. First, this paper addresses conceptual problems with application of the term "effectiveness" and analyzes the potential and limitations of an alternative construct- "performance." In addition, we attempt to systematize current theoretical implications in the field of strategic management and
\end{abstract} sociological theories of organization. We focus on strategic management because performance-related questions are central in this academic discipline. Contrary to their intellectual ancestors in industrial economics, strategists pay closer attention to firm-level internal factors affecting firm performance. This paper examines two concepts central to strategic management: firms' strategies and resources. We analyze strategic choice theory and contingency theory first, then turn our focus to core notions for a resource-based view-a dominant framework in strategy research. This article also addresses a sociological approach to the interpretation of firms' high performance. A sociological understanding of the mechanisms behind performance variety concentrates on external factors (environmental effects). Firm survival and successful adaptation practices are studied in network, ecological, and institutional traditions in sociology. Finally, we discuss methodological challenges in performance research that require a combination of theoretical implications from both fields. In order to build an adequate theory about sources of performance variance, one should include micro- and macro-indicators and explore synergetic effects.

Keywords: performance; effectiveness; resource-based view; strategy; performance measurement; network approach; ecological approach; institutional approach; strategic management.

\section{Acknowledgements}

The author would like to thank E. Berdysheva and M. Markin for their valuable suggestions. Also I would like to express gratitude to my advisor Prof. V. Radaev. This article is an output of a research project "Institutional and Structural Foundations of Markets in Contemporary Russia" implemented as part of the Basic Research Program at the National Research University Higher School of Economics (HSE).

\section{References}

Aldrich H. (2009) Lost in Space, Out of Time: How and Why We Should Study Organizations Comparatively. Studying Differences between Organizations: Comparative Approaches to Organizational Research, vol. 26 (ed. M. Lounsbury), Bingley: Emerald Group Publishing, pp. 21-44. 
Aldrich H., Ruef M. (2006) Organizations Evolving, London: SAGE.

Bain J. (1956) Barriers to New Competition, Cambridge: Harvard University Press.

Barney J. B. (1986) Organizational Culture: Can It Be a Source of Sustained Competitive Advantage? Academy of Management Review, vol. 11, no 3, pp. 656-665.

Barney J. B. (1990) The Debate between Traditional Management Theory and Organizational Economics: Substantive Differences or Intergroup Conflict? Academy of Management Review, vol. 15, no 3, pp. 382-393.

Barney J. (1991) Firm Resources and Sustained Competitive Advantage. Journal of Management, vol. 17, no 1 , pp. 99-120.

Barney J. B. (2001) Resource-Based Theories of Competitive Advantage: A Ten-Year Retrospective on the Resource-Based View. Journal of Management, vol. 27, no 6, pp. 643-650.

Barney J. B., Hansen M. H. (1994) Trustworthiness as a Source of Competitive Advantage. Strategic Management Journal, vol. 15, no S1, pp. 175-190.

Barney J. B., Ketchen D. J., Wright M. (2011) The Future of Resource-Based Theory: Revitalization or Decline? Journal of Management, vol. 37, no 5, pp. 1299-1315.

Barron D. N., West E., Hannan M. T. (1994). A Time to Grow and a Time to Die: Growth and Mortality of Credit Unions in New York City, 1914-1990. American Journal of Sociology, vol. 100, no 2, pp. 381-421.

Baum J. A., Dobbin F. (2000) Doing Interdisciplinary Research in Strategic Management-Without a Paradigm War. Economics Meets Sociology in Strategic Management, vol. 17, (eds. J. A. Baum, F. Dobbin), Bingley: Emerald Group Publishing, pp. 389-410.

Beckert J. (1999) Agency, Entrepreneurs, and Institutional Change. The Role of Strategic Choice and Institutionalized Practices in Organizations. Organization Studies, vol. 20, no 5, pp. 777-799.

Burt R. S. (2004) Structural Holes and Good Ideas. American Journal of Sociology, vol. 100, no 2, pp. 349-399.

Butler J., Priem R. L. E. 2001. Is the Resource-Based "View" a Useful Perspective for Strategic Management Research? Academy of Management Review. 26 (1): 22-40.

Cameron K. S. (1986) Effectiveness as Paradox: Consensus and Conflict in Conceptions of Organizational Effectiveness. Management Science, vol. 32, no 5, pp. 539-553.

Cameron K. S., Whetten D. A. (1983) Organizational Effectiveness: One Model or Several? Organizational Effectiveness: A Comparison of Multiple Models (eds. K. S. Cameron, D. A. Whetten), New York: Academic Press, Inc, pp. 1-24.

Cameron K. S., Whetten D. A. (1994) Organizational Effectiveness: Old Models and New Constructs. Organizational Behavior: The State of the Science (ed. J. Greenberg), Mahwah, NJ: Lawrence Erlbaum Associates, pp. 135-155. 
Carney M., Gedajlovic E. R., Heugens P. P., Van Essen M., Van Oosterhout J. H. (2011) Business Group Affiliation, Performance, Context, and Strategy: A Meta-Analysis. Academy of Management Journal, vol. 54, no 3, pp. 437-460.

Carroll G. R., Khessina O. M. (2005) Organizational and Corporate Demography. Handbook of Population (eds. D. Poston, M. Micklin), New York: Kluwer Academic/Plenum Publisher, pp. 451-477.

Caves R. E., Porter M. E. (1977) From Entry Barriers to Mobility Barriers: Conjectural Decisions and Contrived Deterrence to New Competition. The Quarterly Journal of Economics, vol. 91, no 2, pp. 241-261.

Chakravarthy B. S. (1986) Measuring Strategic Performance. Strategic Management Journal, vol. 7, no 5, pp. 437-458.

Chandler A. D. (1962) Strategy and Structure: Chapters in the History of the American Enterprise, Cambridge: Massachusetts Institute of Technology Press.

Child J. (1972) Organizational Structure, Environment and Performance: The Role of Strategic Choice. Sociology, vol. 6, no 1, pp. 1-22.

Child J. (1997) Strategic Choice in the Analysis of Action, Structure, Organizations and Environment: Retrospect and Prospect. Organization Studies, vol. 18, no 1, pp. 43-76.

Crook T. R., Ketchen D. J., Combs J. G., Todd S. Y. (2008) Strategic Resources and Performance: A MetaAnalysis. Strategic Management Journal, vol. 29, no 11, pp. 1141-1154.

Demsetz H. (1997) The Firm in Economic Theory: A Quiet Revolution. The American Economic Review, vol. 87, no 2, pp. 426-429.

Dess G. G., Robinson R. B. (1984) Measuring Organizational Performance in the Absence of Objective Measures: The Case of the Privately-Held Firm and Conglomerate Business Unit. Strategic Management Journal, vol. 5, no 3, pp. 265-273.

DiMaggio P., Powell W. (2010) Novyy vzglyad na “zheleznuyu kletku”: institutsional'nyy izomorfizm i kollektivnaya ratsional'nost' v organizatsionnykh polyakh [The Iron Cage Revisited: Institutional Isomorphism and Collective Rationality in Organizational Fields]. Journal of Economic Sociology = Ekonomicheskaya sotsiologiya, vol. 11, no 1, pp. 34-56. Available at: https://ecsoc.hse.ru/2010-11-1.html (accessed 12 September 2016) (in Russian).

Dobbin F. (2004) Politicheskaya kul'tura i industrial'naya racional'nost' [Political Culture and Industrial Rationality]. Journal of Economic Sociology = Ekonomicheskaya sotsiologiya, vol. 5, no 1, pp. 43-60. Available at: https://ecsoc.hse.ru/2004-5-1.html (accessed 12 September 2016) (in Russian).

Dobbin F. (2016) Sravnitel'nyy i istoricheskiy podkhody v ekonomicheskoy sotsiologii [Comparative and Historical Approaches to Economic Sociology]. Journal of Economic Sociology = Ekonomicheskaya sotsiologiya, vol. 17, no 3, pp. 37-81. Available at: https://ecsoc.hse.ru/2016-17-3.html (accessed 12 September 2016) (in Russian).

Donaldson L. (2001) The Contingency Theory of Organizations. Thousand Oaks: SAGE Publications. 
Dore R (2008) Razlichiya yaponskoy i anglo-saksonskoy modeley kapitalizma [Distinctions between Japanese and Anglo-Saxon Models of Capitalism]. Journal of Economic Sociology = Ekonomicheskaya sotsiologiya, vol. 9, no 1, pp. 65-78. Available at: https://ecsoc.hse.ru/2008-9-1.html (accessed 12 September 2016) (in Russian).

Fedotov Y. V. (2012) Izmerenie effektivnosti deyatel'nosti organizatsii: osobennosti metoda DEA [Organizational Performance Measurement: Principles of DEA (Data Envelopment Analysis) Approach]. Rossiyskiy zhurnal menedzhmenta = Russian Management Journal, vol. 10, no 2, pp. 51-62. Available at: http:// www.rjm.ru/en/archive/list/t_10_2_2012_g/ (accessed 12 September 2016) (in Russian).

Fiss P., Cambré B., Marx A. (2013) Configurational Theory and Methods in Organizational Research: introduction. Configurational Theory and Methods in Organizational, vol. 38 (eds. P. Fiss, B. Cambré, A. Marx), Bingley: Emerald Group Publishing, pp. 1-23.

Fligstein N. (2001) Organizations: Theoretical Debates and the Scope of Organizational Theory. Department of Sociology, University of California Berkley. Available at: http://sociology.berkeley.edu/sites/default/ files/faculty/fligstein/inter.handbook.paper.pdf (accessed 12 September 2016).

Fligstein N. (2007) Gosudarstvo, rynki i ekonomicheskiy rost [States, Markets and Economic Growth]. Journal of Economic Sociology = Ekonomicheskaya sotsiologiya, vol. 8, no 2, pp. 41-59. Available at: https:// ecsoc.hse.ru/2007-8-2.html (accessed 12 September 2016) (in Russian).

Gereffi G., Frederick S. (2010) The Global Apparel Value Chain, Trade and the Crisis: Challenges and Opportunities for Developing Countries. Global Value Chains in a Postcrisis World: A Development Perspective (eds. G. Gereffi, C. Staritz, O. Cattaneo), Washington: World Bank Publications, pp. 157-209.

Golikova V. V., Gonchar K. R., Kuznetsov B. V. (2012) Vliyanie eksportnoy deyatel'nosti na tekhnologicheskie i upravlencheskie innovatsii rossiyskikh firm [The Impact of Exports on Technological and Management Innovations of the Russian Firms]. Rossiyskiy zhurnal menedzhmenta $=$ Russian Management Journal, vol. 10, no 1, pp. 3-18. Available at: http://www.rjm.ru/en/archive/list/t_10_1_2012_g/ (accessed 12 September 2016) (in Russian).

Goll I., Rasheed A. A. (2005) The Relationships between Top Management Demographic Characteristics, Rational Decision Making, Environmental Munificence, and Firm Performance. Organization Studies, vol. 26, no 7, pp. 999-1023.

Gonchar K. R., Kuznetsov B. V. (eds) (2008) Rossiyskaya promyshlennost'na etape rosta: faktory konkurentosposobnosti firm [Russian Industrial Growth: Factors Aaffecting Firms' Competitiveness], Moscow: Vershina (in Russian).

Goodman P. S., Atkin R. S., Schoorman F. D. (1983) On the Demise of Organizational Effectiveness Studies. Organizational Effectiveness: A Comparison of Multiple Models (eds. K. S. Cameron, D. A. Whetten), New York: Academic Press, pp. 163-183.

Granovetter M. (2002) Ekonomicheskoe deystvie i sotsial'naya struktura: problema ukorenennosti [Economic Action and Social Structure: The Problem of Embeddedness]. Journal of Economic Sociology = Ekonomicheskaya sotsiologiya, vol. 3, no 3, pp. 44-58. Available at: https://ecsoc.hse.ru/2002-3-3.html (accessed 12 September 2016) (in Russian). 
Gresov C., Drazin R. (1997) Equifinality: Functional Equivalence in Organization Design. The Academy of Management Review, vol. 22, no 2, pp. 403-428.

Gudova E. (2016) Effektivnost' s “chelovecheskim litsom": evolyutsiya ponimaniya effektivnosti v teorii organizatsiy [Effectiveness with a human face: Evolution of the notion in the organizational theory]. Monitoring obshchestvennogo mneniya: ekonomicheskie i sotsial'nye peremeny, vol. 131, no 1, pp. 231-239. Available at: http://wciom.ru/fileadmin/file/monitoring/2016/131/2016_131_09_Gudova.pdf (accessed 12 September 2016) (in Russian).

Hannan M. T., Carroll G. (1992) Dynamics of Organizational Populations: Density, Legitimation, and Competition. New York: Oxford University Press.

Hannan M. T., Freeman J. (1977) The Population Ecology of Organizations. American Journal of Sociology, vol. 82, no 5, pp. 929-964.

Hannan M. T., Freeman J. (2013) Populyatsionnaya ekologiya organizatsiy [The Population Ecology of Organizations]. Journal of Economic Sociology = Ekonomicheskaya sotsiologiya, vol. 14, no 2, pp. 42-72. Available at: https://ecsoc.hse.ru/2013-14-2.html (accessed 12 September 2016) (in Russian).

Hinings C., Malhotra N. (2008) Change in Institutional Fields. The Institutions of the Market: Organizations, Social Systems and Governance (eds. N. Beck, A. Ebner), New York: Oxford University Press, pp. 106-128.

Hrebiniak L., Snow C. (1980) Strategy, Distinctive Competence, and Organizational Performance. Administrative Science Quarterly, vol. 25, no 2, pp. 317-336.

Kahn R. L. (1977) Organizational effectiveness: An overview. New Perspectives on Organizational Effectiveness (eds. P. S. Goodman, J. M. Pennings), San Francisco: Jossey-Bass Publishers, pp. 235-248.

Kanter R. M., Brinkerhoff D. (1981) Organizational Performance: Recent Developments in Measurement. Annual Review of Sociology, vol. 7, pp. 321-349.

Keister L. A. (1998) Engineering Growth: Business Group Structure and Firm Performance in China's Transition Economy. American Journal of Sociology, 104 (2): 404-440.

Ketchen D. J., Thomas J. B., Snow C. C. (1993) Organizational Configurations and Performance: A Comparison of Theoretical Approaches. Academy of Management Journal, vol. 36, no 6, pp. 1278-1313.

Kozlowski S., Klein K. (2000) A Multilevel Approach to Theory and Research in Organizations: Contextual, Temporal, and Emergent Processes. Multilevel Theory, Research, and Methods in Organizations: Foundations, Extensions, and New Directions (eds. S. Kozlowski, K. Klein), San Francisco: Jossey-Bass Publishers, pp. 3-90.

Kuznetsov B. V. (ed.) (2010). Predpriyatiya i rynki v 2005-2009 godakh: itogi dvukh raundov obsledovaniya rossiyskoy obrabatyvayushchey promyshlennosti [Firms and Markets in 2005 and 2009: Results from Two Surveys of Russian Manufacturing Companies], Moscow: HSE Publishing House. Available at: https:// www.hse.ru/news/science/17619989.html (accessed 12 September 2016) (in Russian). 
Lavie D., Miller S. R. (2008) Alliance Portfolio Internationalization and Firm Performance. Organization Science, vol. 19, no 4, pp. 623-646.

Le Mens G., Hannan M. T., Pólos L. (2011a) Drifting Tastes, Inertia, and Organizational Viability. Research Paper, no 2082. December, Stanford, USA: Stanford Graduate School of Business. Available at: http:// papers.ssrn.com/sol3/papers.cfm?abstract_id=1912116 (accessed 12 September 2016).

Le Mens G., Hannan M. T., Pólos L. (2011b) Founding Conditions, Learning, and Organizational Life Chances: Age Dependence Revisited. Administrative Science Quarterly, 56 (1): 95-126.

Levitt B., March J. G. (1988) Organizational Learning. Annual Review of Sociology, vol. 14, pp. 319-340.

Lockett A., Thompson S. (2001) The Resource-Based View and Economics. Journal of Management, vol. 27, no 6, pp. 723-754.

March J. G., Stinchcombe A. L. (1965) Social Structure and Organizations. Advances in Strategic Management, vol. 17, pp. 229-259.

March J. G., Sutton R. I. (1997) Crossroads-Organizational Performance as a Dependent Variable. Organization Science, vol. 8, no 6, pp. 698-706.

Mason E. S. (1939) Price and Production Policies of Large-Scale Enterprise. American Economic Review, vol. 29, pp. 61-74.

Meyer A. D., Tsui A. S., Hinings C. R. (1993) Configurational Approaches to Organizational Analysis. Academy of Management Journal, vol. 36, no 6, pp. 1175-1195.

Meyer A. D. (1991) What is Strategy's Distinctive Competence? Journal of Management, vol. 17, no 4, pp. 821-833.

Meyer J. W., Rowan B. (2011) Institutsionalizirovannye organizatsii: formal'naya struktura kak mif i tseremonial [Institutionalized Organizations: Formal Structure as Myth and Ceremony]. Journal of Economic Sociology = Ekonomicheskaya sotsiologiya, vol. 12, no 1, pp. 43-67. Available at: https://ecsoc.hse.ru/201112-1.html (accessed 12 September 2016 ) (in Russian).

Miles R. E., Snow C. C., Meyer A. D., Coleman H. J. (1978) Organizational Strategy, Structure, and Process. Academy of Management Review, vol. 3, no 3, pp. 546-562.

Miller C. C., Cardinal L. B. (1994) Strategic Planning and Firm Performance: A Synthesis of More than Two Decades of Research. Academy of Management Journal, vol. 37, no 6, pp. 1649-1665.

Miller C. C., Washburn N. T., Glick W. H. (2013) Perspective - The Myth of Firm Performance. Organization Science, vol. 24, no 3, pp. 948-964.

Mizruchi M. S. (1996) What do Interlocks Do? An Analysis, Critique, and Assessment of Research on Interlocking Directorates. Annual Review of Sociology, vol. 22, pp. 271-298.

Oliver C. (1997) Sustainable Competitive Advantage: Combining Institutional and Resource-Based Views. Strategic Management Journal, vol. 18, no 9, pp. 697-713. 
Peng M. W., Luo Y. (2000) Managerial Ties and Firm Performance in a Transition Economy: The Nature of a Micro-Macro Link. Academy of Management Journal, vol. 43, no 3, pp. 486-501.

Penrose E. (1959) The Theory of the Firm, New York: John Wiley \& Sons.

Porter M. E. (1981) The Contributions of Industrial Organization to Strategic Management. Academy of Management Review, vol. 6, no 4, pp. 609-620.

Porter M. (2005) Konkurentnaya strategiya: Metodika analiza otrasley i konkurentov [Competitive Strategy: Techniques for Analyzing Industries and Competitors], Moscow: Alpina Business Books (in Russian).

Priem R. L., Butler J. E. (2001) Is the Resource-Based "View" a Useful Perspective for Strategic Management Research? Academy of Management Review, vol. 26, no 1, pp. 22-40.

Richard P. J., Devinney T. M., Yip G. S., Johnson G. (2009) Measuring Organizational Performance: Towards Methodological Best Practice. Journal of Management, vol. 35, no 3, pp. 719-804.

Rivkin J. W. (2000) Imitation of Complex Strategies. Management Science, vol. 46, no 6, pp. 824-844.

Rousseau D. M., Fried Y. (2001) Location, Location, Location: Contextualizing Organizational Research. Journal of Organizational Behavior, vol. 22, no 1, pp. 1-13.

Swedberg R. (2005) Economic Versus Sociological Approaches to Organization Theory. The Oxford Handbook of Organization Theory (eds. C. Knudsen, H. Tsoukas), New York: Oxford University Press, pp. 373-392.

Tambovtsev V. L. (2010) Strategicheskaya teoriya firmy: sostoyanie i vozmozhnoe razvitie [Strategic Theory of the Firm: State of the Art and Possible Development] Rossijskij zhurnal menedzhmenta = Russian Management Journal, vol. 8, no 1, pp. 5-40. Available at: http://www.rjm.ru/en/archive/list/t_v_8_n_1_2010_g/ (accessed 12 September 2016) (in Russian).

Uzzi B. (1997) Towards a Network Perspective on Organizational Decline. International Journal of Sociology and Social Policy, vol. 17, no 7/8, pp. 111-155.

Uzzi B. (1999) Embeddedness in the Making of Financial Capital: How Social Relations and Networks Benefit Firms Seeking Financing. American Sociological Review, vol. 64, no 4, pp. 481-505.

Uzzi B. (2007) Istochniki i posledstviya ukorenennosti dlya ekonomicheskoy effektivnosti organizatsiy: vliyanie setey [The Sources and Consequences of Embeddedness for the Economic Performance of Organizations: The Network Effect]. Journal of Economic Sociology = Ekonomicheskaya sotsiologiya, vol. 8, no 3, pp. 44-60; vol. 8, no 4, pp. 43-59. Available at: https://ecsoc.hse.ru/2007-8-3.html and https://ecsoc. hse.ru/2007-8-4.html (accessed 12 September 2016) (in Russian).

Vedres B., Stark D. (2010) Strukturnye skladki: produktivny razryv v peresekayushchikhsya gruppakh [Structural Folds: Generative Disruption in Overlapping Groups]. Journal of Economic Sociology = Ekonomicheskaya sotsiologiya, vol. 11, no 4, pp. 69-104. Available at: https://ecsoc.hse.ru/2010-11-4.html (accessed 12 September 2016 (in Russian) 
Venkatraman N., Ramanujam V. (1986) Measurement of Business Performance in Strategy Research: A Comparison of Approaches. Academy of Management Review, vol. 11, no 4, pp. 801-814.

Whetten D. A. (2009) Organizational Comparative Analysis: Investigating Similarities and Differences among Organizations. Studying Differences between Organizations: Comparative Approaches to Organizational Research (eds. B. G. King, T. Felin, D. A. Whetten), vol. 26. Bingley: Emerald Group Publishing, pp. 63-87.

Williamson O. (1996) Ekonomicheskie instituty kapitalizma [The Economic Institutions of Capitalism], St. Petersburg: Lenizdat (in Russian).

Yakovlev A. A. (2005) Evolyutsiya strategiy vzaimodeystviya biznesa i vlasti v rossiyskoy ekonomike [Evolution of Business-State Interaction Strategies in the Russian Economy]. Rossiyskiy zhurnal menedzhmenta = Russian Management Journal, vol. 3, no 1, pp. 27-52. Available at: http://www.rjm.ru/en/archive/ list/t_3_1_2005_g/ (accessed 12 September 2016) (in Russian).

Zahra S. A., Pearce J. A. (1990) Research Evidence on the Miles - Snow Typology. Journal of Management, vol. 16, no 4, pp. 751-768.

Zucker L. G. (1987) Institutional Theories of Organization. Annual Review of Sociology, vol. 13, pp. 443-464.

Received: September 9, 2016.

Citation: Romanova R. (2016) Uspekh firmy: chto eto takoe, ot chego on zavisit i kak ego izmerit' [Firm Performance: How to Define it, What Affects it and How to Deal with Measurement Challenges]. Journal of Economic Sociology = Ekonomicheskaya sotsiologiya, vol. 17, no 4, pp. 164-189. Available at: https://ecsoc. hse.ru/2016-17-4.html (in Russian). 


\section{И. В. Павлюткин}

\section{Политическая экономия}

\section{академического обм(е)ана, или Как социологи становятся профессорами}

Рецензия на книгу: Соколов М., Губа К., Зименкова Т., Сафонова М., Чуйки-

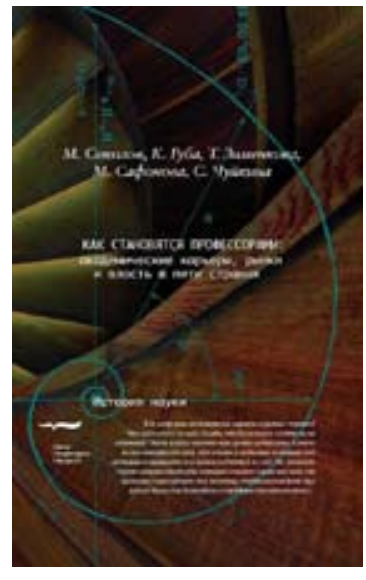
на С. 2015. Как становятся профессорами: академические карьеры, рынки и власть в пяти странах. М.: Новое Литературное обозрение (серия «История науки»). 832 с.

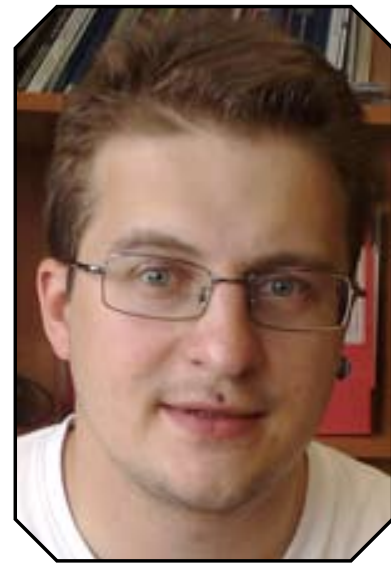

\section{ПАВЛЮТКИН Иван} Владимирович кандидат социологических наук, доцент департамента социологии, старший научный сотрудник Лаборатории экономикосоциологических исследований Национального исследовательского университета «Высшая школа экономики». Адрес: 101000, Россия, г. Москва, ул. Мясницкая, д. 20.

Email: ipavlutkin@hse.ru
Рецензия посвящена коллективной монографии «Как становятся профессорами: академические карьеры, рынки и власть в пяти странах», вышедшей в издательстве «Новое Литературное обозрение». Авторы объёмного издания преследовали две иели. Во-первых, подготовить путеводитель по академическим карьерам во Франции, в Германии, США, Великобритании и России для молодых сочиологов, задумываюшихся о своём профессиональном пути. Опираясь на различные источники (материальы интервью, вторичные данные, автоэтнографию), авторам удалось представить институциональную историю формирования академической социологии как профессии и описать эволючию ключевых переходов в трудовой биографии социологов пяти стран. Во-вторых, сравнив и обнаружив определённые различия в институциональных и внеинституциональных механизмах найма социологов, авторы предлагают теоретическое объяснение этих различий, используя категорию «оптические системы» как культурную рамку, через которую те или иные агенты, обладающие ресурсами и мотивами, смотрят на университеты. Поскольку, по мнению авторов, в основании динамики академических миров лежит смена «словарей подозрений», оптические системы позволяют хотя бы на время справиться с всеобщим недоверием и страхом быть обманутым «благородными жуликами». В реиензии дан краткий разбор отдельных глав книги, описаны безусловные достоинства монографии и её условные недостатки. В книге поднимается несколько важных тем, обсуждаемых сегодня в экономической социологии на разных эмпирических примерах: взаимосвязь морали и рынков; как работают стимуль и как наблюдать их эффектыл; являются ли институтьл заменителями доверия. Несмотря на провокационность отдельных тезисов, разоблачительность комментариев и дискуссионныи характер выводов, книга, безусловно, заслуживает прочтения всеми, кто так или иначе вовлечён в современную систему высшего образования и науки, - нынешними и будущими академиками, чиновниками, управленцами и, конечно, теми, кто именует себя экспертами.

Ключевые слова: академическая карьера; оптические системы; институциональная история; мораль; академические рынки; мертонианский вопрос. 
В своём роде академический мир является чем-то вроде сверхсложной аферь или шиионской операчии под прикрытием, в которой никто до кониа не может быть уверен, что знает, кто в действительности на кого работает, пока не наступила развязка - а она и не думает наступать (c. 692).

В издательстве «Новое Литературное обозрение» вышла коллективная монография о том, как устроены национальные академические миры, населённые племенами «социологов-карьеристов» в пяти странах - во Франции, в Германии, США, Великобритании и России. В книге собраны и обобщены результаты нескольких исследовательских проектов, реализованных коллективом авторов в рамках социологии локальных академических сообществ и теории статусного символизма в науке (с. 24).

Дать ёмкое и говорящее название рецензии на прочитанную книгу — дело непростое. В книгу включено слишком много отдельных вопросов, тезисов и аргументов. Она также изобилует теоретическими вставками и концептами - здесь переплетены и статусный символизм в науке, и разные версии институционализма, и политическая экономия университетов, и стратегическая коммуникация академических агентов. Несмотря на, казалось бы, узкий интерес авторов именно к карьерам социологов, эти последние являются в книге, скорее, наглядным примером или поводом для того, чтобы пообсуждать более широкие вопросы организации академического поля и возможностей адекватного теоретического и практического взгляда на его устройство. В начале книги авторы обозначают два плана её замысла. Первая цель заключается в подготовке путеводителя для начинающих и прагматичных академиков ${ }^{1}$, задумывающихся о собственном будущем в социологии. Описанные случаи национальных систем академического найма сопровождаются практическими рекомендациями для желающих попасть в струю карьерного продвижения. Кто-то после прочтения книги поймёт, что уже опоздал, отучился не в том месте или не в то время либо не готов тратить свою жизнь на жёсткую конкурентную борьбу, а кто-то, наоборот, почувствует силы в покорении академического олимпа где-нибудь в Германии или в США. Вторая цель, преследуемая авторами, - предложить объяснение наблюдаемой в сравнительной перспективе истории институционализации академических карьер в социологии. В книге несколько раз поднимается так называемый большой мертонианский вопрос о поиске правильного устройства академического сообщества. Этот вопрос волнует всех участников похода к совершенной академической жизни - и многоликого чиновника, вынужденного принимать обоснованные решения о расходах в обмен на демонстрацию результатов и контролировать их исполнение, и университетского администратора, вынужденного обеспечивать оперативное и стратегическое управление большими коллективами не всегда дружелюбных академиков в условиях множественных внешних запросов и ожиданий, и представленных разными поколениями преподавателей и исследователей, вынужденных задумываться о своей карьере, вознаграждении и признании, проходя всевозможные экспертизы, отборы, конкурсы, диспансеризации и проч. Кстати, может показаться, что наиболее беззащитными являются изрядно уставшие академики, но вышедшая книга последовательно развенчивает миф о «слабом академике», участвующем в разнообразных карьерных экспериментах администраторов и чиновников. В разных национальных академических мирах эти участники обладают разным весом, аппетитом и возможностями его удовлетворить. При разговоре о правильном устройстве университета одних будет занимать

В данном случае под академиками в широком смысле понимаются преподаватели и исследователи, работающие в разных организациях, а не только в Академии наук. Как пишут сами авторы, в России слово «академический» ассоциируется с Академией наук. В англо-американской традиции слово academic, наоборот, «исходно относится к сфере высшего образования, хотя и может быть употреблено расширительно для обозначения любых организаций, в которых работают учёные» (с. 5). 
вопрос о справедливости распределения ресурсов, прозрачности механизмов отбора, продвижения кандидатов и получения постоянной позиции, а других - вопрос эффективности, который неизбежно будет выводить на первый план одних кандидатов и дискриминировать других. Вышедшая книга последовательно показывает, как сформировавшиеся за несколько столетий академические миры разных стран научились последовательно опровергать всевозможные подозрения в своём несовершенстве.

Желание совместить две задачи, а именно создать путеводитель карьериста-социолога и в то же время предложить адекватную теорию объяснения взаимосвязи карьерных лестниц и стратегий академиков, сделало книгу довольно объёмным и всеобъемлющим трактатом о мифах и парадоксах академической мобильности. «Как становятся профессорами...» - труд, превышающий по объёму 800 страниц. По признанию самих авторов, книга долго готовилась к изданию, а отдельные тезисы и доклады о российской социологии и социологах можно было прочитать в отечественных социологических журналах несколько лет назад [Соколов 2009; Соколов 2011; Сафонова 2012]. Книгу интересно читать. Монография насыщена богатым эмпирическим материалом, интересными биографическими и историческими фактами о социологах, университетах, образовательных и научных реформах XX века. В отдельных главах книга напоминает детектив или материалы расследования с привлечением цитат из интервью с основными участниками карьерного рынка. Академические системы пяти стран последовательно разоблачаются, при этом демонстрируется невидимая для «чужака» сторона процесса академического найма и завоевания академического олимпа.

Надо сказать, что это провокационная книга. Авторы несколько раз просят закрыть её тех романтиков и идеалистов, которые не готовы воспринимать приземлённую экономическую историю академического обмена. Такие книги неоднозначны при пересказах и интерпретациях. Невольно задаёшься вопросом: действительно ли авторы искренне думают именно так, как пишут, или это особенности академического стиля или чувства юмора? В книге можно найти фразы, способные стать крылатыми. Например, «теория обмена неполна без теории обмана» (с. 695) или «стремление избежать неудачи порождает интеллектуальную стерильность» (с. 808).

Книга состоит из предисловия, шести глав и заключения. Каждая глава, кроме шестой («Вместо заключения...»), посвящена институциональной истории одной из национальных систем академического найма социологов. Первая глава рассказывает о социологической карьере и институциональном многообразии французского академического мира; вторая повествует о тяжёлой судьбе социологического карьеризма в Германии; третья представляет мир американской социологии и кастовую архитектуру её академического найма; четвёртая глава объясняет принципы найма социологов в мире статусной иерархии британских университетов и департаментов; наконец, пятая расскажет читателю о силе дружеских сетей в российском академическом мире, а также о трёх племенах постсоветских социологов, предъявляющих разные требования к вопросам найма и продвижения академиков. При написании таких историй авторы опираются на разные виды источников и фокусируются то на индивидах, то на организациях.

Так, главы, посвящённые Германии и Франции, рассказывают об академическом найме с позиции самого карьериста, опираются на так называемую автоэтнографию, а также на экспертные интервью и вторичные материалы релевантных сайтов. Американская и британская главы написаны с опорой на интервью с преподавателями и администраторами, но в фокусе находятся не карьеристы, а организации, их нанимающие. Наконец, российская глава опирается на большой объем эмпирического материала - как интервью, так и количественные данные, - собранного за несколько лет исследований. Шестая глава монографии с громким названием «Академические карьеры, легитимные оптические системы и большой мертонианский вопрос» представляет собой попытку объяснить эволюции научных миров и закон академической карьеры с опорой на словари подозрений и политическую экономию ака- 
демического обмана. Как пишут сами авторы, «культурную историю науки можно написать как смену словарей подозрений, которые широко применялись в отношении учёных. Эти словари можно классифицировать по эталонным фигурам антигероев, с которыми сравниваются реальные индивиды. Те её эпизоды, которые покрывает наша книга, в основном связаны с пришествием одного из них - словаря доктора Вов-Ху» (с. 692). В самом заключении авторы занимают определённую позицию, предлагая возможные варианты позитивного ответа на большой мертонианский вопрос и обсуждая условия положительного исхода борьбы с академическими пороками.

В течение всей книги авторы обсуждают так называемый большой мертонианский вопрос о системе «вознаграждений» в науке, обеспечивающих рост научного знания. С одной стороны, в поле науки и образования всё время «взращиваются» таланты, идеи, открытия - необходимое содержание академической жизни и занятий. С другой стороны, само взращивание определяется социальной организацией академических сообществ. Изначально постановка вопроса звучит так: «<.. > Какое из устройств академического мира обеспечивает наибольшую поддержку для таланта и оригинальности, и какое наиболее благоприятно для порождения и развития революционных идей?» (с. 20). Проведённое исследование пяти национальных систем отбора и воспроизводства научных работников приводит авторов к выводам, которые сложно назвать оптимистическими. Каждая из описанных систем, наряду с формальными институтами, обладает невидимой системой консенсусов, когда важными факторами построения академической карьеры становятся академическая генеалогия, научный протекционизм, лояльность, а иногда и дружба, которые рисуются как дискредитирующие значимые для развития науки «академические добродетели». Вместе с тем не трудно заметить, что уже в конце своего исследования поставленный авторами вопрос переформулируется несколько раз. Институциональная теория подозрений, предлагаемая для объяснения эволюции оптимальных карьерных стратегий в науке, предлагает иную постановку мертонианского вопроса: «Какая оптическая система наиболее успешна в стимулировании интеллектуальной деятельности коллективов, которые сквозь неё рассматривают?» (c. 694). В центре рассуждений находится возможность интеллектуальной работы в изначальной рамке недоверия и оппортунизма. Такая возможность выступает необходимым условием коалиционной игры, в которой каждый из агентов просчитывает выигрыши и проигрыши от вступления во взаимодействие. Сложность этой игре добавляет то, что в неё вовлечены агенты двух родов - не только (1) непосредственных участников академического обмена, но и тех, кто (2) выполняет функцию наблюдателей и оценщиков. Поскольку академическое взаимодействие исходит из ожидания виновности каждой из сторон, то агенты второго рода призваны дать независимую оценку и позволить принципалам и агентам первого рода принять адекватные решения. Проблема, однако, заключается в том, что сами агенты второго рода могут стать участниками сговора, и это порождает необходимость уже контроля над ними. Авторы описывают разные издержки и выгоды от разных форм осуществления такого контроля. В итоге, по мнению авторов, мы неизбежно приходим к главному вопросу, который позволяет объяснить различия в эволюции национальных академических систем, а именно: «Кто сторожит сторожей?». Вывод из анализа разных систем академического найма описан следующим образом: «Институты, придающие форму индивидуальным исследовательским карьерам, — морфология позиций с их правами и обязанностями, легитимные процедуры их заполнения, принципы принятия самых разных решений в академических организациях - возникают как своего рода политические компромиссы. Одной стороной этого компромисса являются разные группы аутсайдеров, желающих верить в сохранение контроля над происходящим внутри. Они требуют, чтобы им демонстрировали показатели, которые, как они считают, могут распознать, и провели процедуры в соответствии с тем, что кажется им гарантией добросовестности поведения участников. Второй стороной компромисса являются инсайдеры, которые несут экономические и моральные издержки, связанные с контролем над ними, но одновременно могут рассчитывать на выигрыши, если новая оптическая система позволит им перераспределить ресурсы в свою пользу» (с. 720). 
В самом конце книги, однако, появляется другая версия мертонианского вопроса, которая отражает собственно позицию авторов на разрешение проблемы интеллектуального застоя: «В каких институциональных условиях интеллектуальное превосходство становится рыночным преимуществом?» (с. 797). И, отвечая на этот вопрос, авторы не придумали ничего лучше, как указать на конкуренцию за талант и контроль сообщества (или дисциплинарный салонный контроль), очищенного от сетевых связей, которые и становятся угрозой для развития дисциплины. Вот что пишут сами авторы, описывая российский случай: «Печальная особенность сети состоит в том, что возникающее обязательство тем больше, чем меньше шансов было бы у получателя блага стать его обладателем на основе чистых заслуг» (с. 518).

Монография, безусловно, поможет расширить читательский кругозор и разобраться в работе пяти академических систем в сравнительной и исторической перспективе. Избирательное сродство институтов, ресурсов и мотивов (а шире - морали) позволяет обнаружить специфику французской, американской, немецкой, британской и российской моделей академического найма. Сравнительное описание специфики также снимет у ряда коллег, наиболее переживающих за судьбу «российской социологии», наболевшие вопросы о том, почему у нас не так, как у них, а у них не так, как у нас.

В действительности академические системы выбранных для анализа стран обладают несколькими общими чертами. Во всех описанных случаях можно наблюдать примерно одинаковый набор уровней, составляющих преподавательскую иерархию: позиции ассистента, доцента и профессора. В каждой стране присутствуют свои дополнительные ответвления, которые работают как промежуточные звенья в карьерных цепочках. Где-то, как в России, дополнительно выделяются позиции преподавателя и старшего преподавателя, в Германии - позиции младшего и полного профессора. В Великобритании различие позиций задаётся обязательствами преподавателя и исследователя. Общими для всех иерархических систем академического найма является связь последовательности перехода на новую ступень и возможностей, ею предоставляемых (длительность контракта, свобода выбора направления, наличие административных обязанностей, величины заработной платы и т. п.) (с. 726-727). Вместе с тем, каждая система обладает собственной конфигурацией организационных форм академической работы, дисциплинарных границ, институтов индустриального и салонного контроля, разнообразия ресурсных ниш и типов контрактов.

Из описания французского случая мы узнаём о том, как приходится выстраивать карьеру социологу в мире институционального разнообразия. Несмотря на определяющую роль государства в институционализации французской социологии, академия здесь не является организационно единообразной. В этом поле сосуществуют разные институции, принимающие на работу социологов и выделяющие гранты на их работу. Французские университеты, grande ecole и grand établissements, - всё это разные категории учреждений, предъявляющие разные требования к найму и продвижению преподавателей и научных сотрудников. Возникнув в разное время и под разные задачи, Нантский университет, Эколь Нормаль, Высшая школа исследований в социальных науках обладают разным статусом и ожидают от своих сотрудников разного усердия в преподавании, исследованиях, административной работе. Государственный центр научных исследований также становится важным работодателем для социологов, распределяя финансирование для научных лабораторий в университетах. В системе отбора и продвижения преподавателей необходимо для начала защитить диссертацию и получить квалификацию в государственном университетском совете (с. 103). В дальнейшем, при переходе на постоянную позицию доцента или на чисто научную позицию в лаборатории, приобретают значение «профиль», изданные книги и публикации, административное рвение. Процедуры найма в разных категориях учреждений также различаются по составу комиссий, принципу голосования и рассмотрению кандидатур. Напряжение возникает при переходе доцента в профессоры, что предполагает получение и защиту хабилитации, а в дальнейшем - прохождение квалификации в государственном университетском совете 
(с. 135). Помимо публикаций, исследовательского и административного опыта, приобретают значение политические факторы, наличие связей в том или ином научном лагере, обеспечивающих протекцию кандидату. Зачастую именно здесь проявляется борьба научных школ за собственное воспроизводство. В этом смысле один из практических советов заключается в выборе научного руководителя и темы диссертации. На вершине академического олимпа находится статус «мандарина», обладающего символической властью в академическом мире: «Его имя известно любому члену сообщества; о нём ходит много слухов, в частности о том, что он может пристроить любого своего ученика; он занимает несколько позиций на стыке между научным и “внешним” миром; и некоторые из этих статусов почётны, он является не только учёным, но и интеллектуалом широкого профиля» (с. 141). Мандарины — люди неординарные, а их биографии атипичны. Как пишут авторы рецензируемой книги, до мандарина надо «дозреть».

Описание архитектуры британского академического рынка, на котором нанимаются и трудятся социологи, начинается с важного замечания, которое определяет институциональный ландшафт всей университетской системы. Речь идёт о том, что иерархия британских университетов связана с порядком их возникновения (с. 325). Отдельными признаками существования такой иерархии являются позиции британских университетов и департаментов в рейтингах, доля средств, выделяемых на науку через финансовые советы, объём эндаумента и уровень студентов, зачисленных на программы бакалавриата и др. Принцип «порядок рождения определяет статус» обеспечивает воспроизводство иерархии не только университетов, но и отдельных дисциплин. Вместе с тем институционализация британской социологии начинается не в старых, а в более молодых краснокирпичных университетах, что определило её более высокий статус именно в них, а не в Оксбридже. Система академических позиций является наиболее разветвлённой в силу наличия нескольких треков - преподавательского, исследовательского или смешанного. Они, в свою очередь, имеют внутреннюю систему рангов, на вершине которых находится профессорская позиция. По отношению к разным трекам будут характерны разные системы стандартов и оценок. Британский академический мир включает централизованные системы оценивания исследований (Research Assessment Exercise - RAE) и преподавания (Quality Assurance Agency for Higher Education - QAA), представленные соответствующими агентствами. B зависимости от оценок, получаемых академиками, происходит ранжирование департаментов, что учитывается при распределении финансирования. С одной стороны, британский случай академического найма и карьеры является наиболее открытым и предсказуемым, а с другой - рынок труда здесь сегментирован, что повышает роль клубных или личных — оставшихся со времён обучения в докторантуре - связей кандидатов.

Германская система построения академической карьеры характеризуется в рецензируемой книге как наиболее жёсткая и забюрократизированная. «Неуверенность в завтрашнем дне и сложность обретения постоянной позиции являются непрекращающейся болью учёных в Германии» (с. 157). Отсутствие ярко выраженной иерархии и конкуренции университетов, характерное для британской и американской систем найма, компенсируется набором ограничений, запретов и процедур, не позволяющих кандидату сидеть на одном месте. В этом наборе - ограничения академического времени и запрет на внутривузовское назначение на должность. Уже в самом начале пути кандидат ограничен временными рамками подготовки и защиты диссертации (шесть лет) и в дальнейшем - хабилитации (тоже шесть лет). Несмотря на снижение веса этой последней, для получения профессорской должности и введением самодостаточной позиции младшего профессора хабилитация до сих пор имеет значение входного билета в академическую элиту. Не являясь формальной степенью, хабилитация является самым жёстким статусным ритуалом академической биографии в Германии (с. 180). Дополнительно узкая специализация, характерная для академической работы в Германии, задаёт определённые требования к исследованиям и журнальным публикациям социологов. Занятию профессорской позиции предшествует длительный период согласования вакансий и заявок на уровне факультета и ректората, комиссии 
и рецензирование работ кандидата. Подводя итоги, в самом конце немецкой главы авторы советуют: «Прочитай другие главы этой книги и подумай: может быть, вместо Германии попытать счастье гденибудь ещё?» (с. 228).

Институциональное устройство американского академического мира сильно выделяется на фоне остальных. Его населяют как государственные, так и частные университеты с широкой экономической и управленческой автономией, а также с сильной конкуренцией за аудитории и ресурсы как на уровне университетов, так и на уровне отдельных департаментов. Роль государственных регулирующих и контролирующих органов сводится к минимуму, а роль различных профессиональных и сертифицирующих ассоциаций, напротив, является значительной. Большинство позиций на академическом рынке труда не долгосрочны и уж тем более не пожизненны (tenure). Преподаватели меняют несколько университетов в течение академической биографии, пока им не выпадет шанс вступить в серьёзные отношения с одним-единственным университетом. Три кита американского академического найма это известность степени, рекомендации от значимых учёных и публикации в хороших журналах. Опираясь на обзор количественных исследований, авторы утверждают, что «публикационная активность является менее важным фактором при принятии решения о найме, чем академическая генеалогия, то, какой университет присвоил кандидатскую степень» (с. 237). Нельзя сказать, что публикации и рекомендации не имеют значения, но внимание к ним часто опосредуется именно принадлежностью степени к определённому университету.

Российский случай академических карьер описывается наиболее подробно. Ему присущи институциональное многообразие, не меньшее, чем во французском академическом мире; схожая с британским случаем централизация в части процедур оценивания преподавания и публикационной активности; дистанция по отношению к американскому кейсу в части значения профессиональных ассоциаций (салонного контроля), роли инбридинга и мобильного рынка академических вакансий. Российский, или постсоветский, случай академической социологии характеризуется сосуществованием нескольких политических культур и сетей обменов внутри одного национального кейса. Выделенные сети, или академические племена, названы авторами книги по типу приверженности той или иной модели академической жизни вест-сайдом, ист-сайдом и олд-центром. Интересные различия в культурно-политических взглядах разных сторон социологического бомонда можно увидеть в приведённой авторами на страницах 530-531 таблице 2 (глава 5 «Интерлюдия: сети и культуры в российской социологии»), на так называемой шкале либерализма - консерватизма. Говорящие названия выделенных племён дополняются буквально персонализированными сетями их связей и академического внимания. Важно, что различия между ними просматриваются в стилях академической работы, принципах контроля, ориентациях на разные ресурсные ниши и, в конечном счёте, в утверждении разных оптических систем.

Сравнивая пять академических систем, авторы опираются на несколько критериев: (1) степень отклонения от традиционной модели классового профессорского контроля (ближе Германии) в сторону либо демократической, либо менеджериальной (ближе США и Великобритании); (2) значение централизованных коллегиальных органов, репрезентирующих дисциплины (США); (3) стимулирующий соревновательный (США, Британия) или селективный (Франция, Германия) характер продвижения сотрудников по карьерной лестнице; (4) значение индустриальных оптических систем (формальных показателей) в регулировании академических рынков (с. 786-787). Культурная разнородность российского случая позволяет увидеть смещение на данных шкалах в зависимости от принадлежности к западному, восточному или старому режиму академической жизни.

Книге, насыщенной разнообразными и многозначными терминами, не хватает единого предметного указателя. Он позволил бы собрать теоретический словарь для описания национальных академических миров, а также определить, как используемые концепты пронизывают разные части монографии 
и нет ли где смещений в сторону американской или российской главы, которые, судя по описанию, в большей степени соответствуют модели институционализации подозрений, чем, например, немецкая или французская глава. Отдельного интереса заслуживает категория «оптические системы». С её помощью объясняется динамика рынков академического найма. Авторы определяют оптические системы как «наборы упорядоченных категорий и правил, которые используются для помещения объекта в ту или иную категорию» (с. 688). Экономическая социология в известной степени отличается разнообразием подходов и концептов, которые вбрасываются в результате авторских исследований промышленной политики, корпоративного управления, систем здравоохранения и т. д. По ходу знакомства с новыми публикациями в рамках так называемого политико-культурного подхода к рыночным институтам возникает желание уточнить и прояснить известные понятия, которые позволяют или не позволяют увидеть похожее на разных объектах или, наоборот, разное на одинаковых. Так, определение понятия «оптическая система» и его дальнейшая операционализация перекликаются с понятием «концепция контроля» ${ }^{2}$, используемым Н. Флигстиным для объяснения воспроизводства стабильного порядка рыночного взаимодействия, и с понятием «институциональные логики» ${ }^{3}$, используемым Р. Фридлендом и Р. Альфордом, Р. Скоттом, П. Торнтон для демонстрации разных институциональных порядков, направляемых институциональными акторами, например, в сферах здравоохранения и издательском бизнесе. Самоопределение по отношению к известным концептуализациям институциональной и политической динамики позволило бы вписать работу в генеральную рамку институциональной теории.

Институциональная история академического найма социологов, написанная коллективом авторов, в известной степени пересекается с не так давно вышедшей монографией Марион Фуркад «Экономисты и общества» [Fourcade 2009]. Один из тезисов книги Фуркад состоит в том, что историю формирования экономической профессии и экономического знания нельзя писать просто как историю экономических идей и учений, сменяющих друг друга и являющихся универсальными независимо от национального контекста. Бросая вызов идее универсализма экономики, Фуркад показывает, каким образом политическая культура во Франции, в Великобритании и США определила процесс институционализации принципиально разных типов экономической профессии в течение XX века. Это, в свою очередь, определило и определяет до сих пор, каким образом экономисты производят знание о реальности хозяйства и как оценивают разные политические суждения об управлении экономикой [Fourcade 2009: 6]. Было бы интересно связать логику развития институциональной истории академического найма и производство знания. Какие теории, методы, инструменты, а в результате - идеи, вопросы и знания о социальной реальности выходят на первый план? А какие, наоборот, переходят на склад академической индустрии и, возможно, никогда не дождутся своего ренессанса? Что происходит с социологическим знанием и его востребованностью разными агентами, если академическая генеалогия, протекционизм, статусная замкнутость, эпохализм и т. п. признаются элементами национальных систем академической мобильности?

2 «Концепции контроля (conceptions of control) обозначают представления, структурирующие восприятие того, как работает рынок, и позволяющие акторам интерпретировать свой мир и контролировать ситуации. Концепция контроля это одновременно и мировоззрение, позволяющее акторам объяснять действия других, и представление о том, как структурирован рынок» [Флигстин 2003: 47].

3 Институциональные логики (institutional logics) - это совокупность материальных практик и символических конструкций, которые конституируют принципы организации поля и могут достраиваться коллективными и индивидуальными акторами [Friedland, Alford 1991: 248]. Трансформация господствующих логик, в том числе правил (например, позволяется ли представителям альтернативной медицины лечить больных) и систем убеждений (например, следует ли федеральному правительству оплачивать медицинские услуги), отражает серьёзные изменения в организационном поле [Скотт 2007: 30]. 


\section{Литература}

Доббин Ф. 2012. Формирование промышленной политики: Соединённые Штаты, Великобритания и Франщия в период становления железнодорожной отрасли. М.: Изд. дом ВШЭ.

Сафонова М. А. 2012. Сетевая структура и идентичности в локальном сообществе социологов. Социологические исследования. 6: 107-120.

Скотт Р. 2007. Конкурирующие логики в здравоохранении: профессиональная, государственная и менеджериальная. Экономическая социология. 8 (1): 27-44. URL: https://ecsoc.hse.ru/2007-8-1.html

Соколов М. М. 2009. Несколько замечаний о девальвации учёных степеней:Экономико-социологический анализ динамики символов академического статуса. Экономическая социология. 10 (4): 14-30. URL: https://ecsoc.hse.ru/2007-8-1.html

Соколов М. М. 2011. Рынки труда, стратификация и карьеры в советской социологии. Экономическая соииология. 12 (4): 37-72. URL: https://ecsoc.hse.ru/2011-12-4.html.

Флигстин Н. 2003. Рынки как политика: политико-культурный подход к рыночным институтам. Экономическая сочиология. 4 (1): 45-63. URL: https://ecsoc.hse.ru/2003-4-1.html.

Friedland R., Alford R. 1991. Bringing Society Back in Symbols, Practices, and Institutional Contradictions. In: Powell W. W., DiMaggio P. J. (eds) The New Institutionalism in Organizational Analysis. Chicago: University of Chicago Press; 232-263.

Fourcade M. 2009. Economists and Societies: Discipline and Profession in the United States, Britain, and France, 1890s to 1990s. Princeton: Princeton University Press. 


\title{
NEW BOOKS
}

\section{Ivan Pavlyutkin}

\section{Political Economy of Academic Exchange: How Do Sociologists Become Professors?}

Book Review: Sokolov M., Guba K., Zimenkova T., Safonova M., Tchuykina S. (2015) Becoming a Professor: Academic Careers, Markets and Power in Five Countries, Moscow: New Literary Observer, 832 p.

PAVLYUTKIN, Ivan - PhD in

Sociology, Associate Professor, Department of Sociology; Senior

Research Fellow, Laboratory for

Studies in Economic sociology, National

Research University Higher School of

Economics. Address: 20 Myasnitskaya

str., Moscow, 101000, Russian

Federation

Email: ipavlutkin@hse.ru

\begin{abstract}
This review discusses the collective monograph "Becoming a Professor: Academic Careers, Markets and Power in Five Countries" published by New Literary Observer in Moscow. The authors of this voluminous book pursued two goals at the same time. First, they sought to prepare a guidebook on academic careers in France, the USA, Germany, Great Britain, and Russia for young sociologists who are thinking ahead about their professional pathway. Based on various data sources (interviews, secondary data, autoethnography), they present an institutional history of the formation of academic sociology as a profession and describe the main trajectories
\end{abstract} in the academic biography of sociologists in five countries. Second, they find differences in institutional and extra-institutional mechanisms of recruitment for sociologists and offer a theoretical explanation. They offer the category of "optical systems" as a cultural framework of university organization used by various external and internal agents with different types of resources and motivation. "Optical systems" become an important source of coping with distrust and the fear of being cheated by "noble swindlers, " since the dynamics of the academic world are forced by the replacement of the suspicions vocabulary. In this review, we give a brief analysis of the chapters, presenting the advantages and weaknesses. This book discusses several important issues: morals and markets in academia; the impact and work of economic incentives; and the strengths and weaknesses of social networks, academic pathways, and political culture. Because of its provocative statements, incriminating comments, and polemic conclusions, this book is worth reading for all those who are involved in the modern system of higher education and science - academics, civil servants, governors, and of course, various experts.

Keywords: academic career, optical systems, institutional history, moral, academic markets, Mertonian question.

\section{References}

Dobbin F. (2012) Formirovanie promyshlennoy politiki: Soedinennye Shtaty, Velikobritaniya i Frantsiya $v$ period stanovleniya zheleznodorozhnoy otrasli [Forging Industrial Policy. The United States, Britain, and France in the Railway Age], Moscow: HSE Publishing House (in Russian).

Friedland R., Alford R. (1991) Bringing Society Back in Symbols, Practices, and Institutional Contradictions. The New Institutionalism in Organizational Analysis (eds. W. W. Powell, P. J. DiMaggio), Chicago: University of Chicago Press, pp. 232-263. 
Fligstein N. (2003) Rynki kak politika: politiko-kul'turnyj podhod k rynochnym institutam [Markets as Politics: A Political-Cultural Approach to Market Institutions]. Journal of Economic Sociology = Ekonomicheskaya sotsiologiya, vol. 4, no 1, pp. 45-63. Available at: https://ecsoc.hse.ru/2003-4-1.html (accessed 22 September 2016) (in Russian).

Fourcade M. (2009) Economists and Societies: Discipline and Profession in the United States, Britain, and France, 1890s to 1990s, Princeton: Princeton University Press.

Safonova M. A. (2012) Setevaya struktura i identichnosti v lokal'nom soobshchestve sotsiologov [Network Structure and Identities in the Local Community of Sociologists]. Sotsiologicheskie issledovaniya, no 6, pp. 107-120 (in Russian).

Scott R. (2007) Konkuriruyushchie logiki v zdravookhranenii: professional'naya, gosudarstvennaya i menedzherial'naya [Competing Logics in Healthcare: Professional, State and Managerial]. Journal of Economic Sociology = Ekonomicheskaya sotsiologiya, vol. 8, no 1, pp. 27-44. Available at: https://ecsoc.hse. ru/2007-8-1.html (accessed 22 September 2016) (in Russian).

Sokolov M. M. (2009) Neskol'ko zamechaniy o deval'vatsii uchenykh stepeney: ekonomiko- sotsiologicheskiy analiz dinamiki simvolov akademicheskogo statusa [Some Remarks on Devaluation of Academic Degrees: Dynamics of Symbols of Academic Status from Economic Sociology Perspective]. Journal of Economic Sociology = Ekonomicheskaya sotsiologiya, vol. 10, no 4, pp. 14-30. Available at: https://ecsoc. hse.ru/2009-10-4.html (accessed22 September 2016) (in Russian)

Sokolov M. M. (2011) Rynki truda, stratifikatsiya i kar'ery v sovetskoy sotsiologii [Labour Markets, Stratification and Careers in the Soviet Sociology]. Journal of Economic Sociology = Ekonomicheskaya sotsiologi$y a$, vol. 12, no 4, pp. 37-72. Available at: https://ecsoc.hse.ru/2011-12-4.html (accessed 22 September 2016) (in Russian).

Received: September 19, 2016

Citation: Pavlyutkin I. (2016) Politicheskaya ekonomiya akademicheskogo obm(e)ana, ili Kak sotsiologi stanovyatsya professorami [Political Economy of Academic Exchange: How Do Sociologists Become Professors?]. Book Review: Sokolov M., Guba K., Zimenkova T., Safonova M., Tchuykina S. (2015) Becoming a Professor: Academic Careers, Markets and Power in Five Countries, Moscow: New Literary Observer, 832 p. Journal of Economic Sociology = Ekonomicheskaya sotsiologiya, vol. 17, no 4, pp. 190-200. Available at: https://ecsoc.hse.ru/2016-17-4.html (in Russian). 


\title{
КОНФЕРЕНЦИИ
}

\section{Г. Е. Новиков}

\section{Нужно ли заниматься крупными темами в социологии?}

\author{
Семинар Лаборатории экономико-социологических исследований, \\ 6 сентября 2016 г., Москва, Россия
}

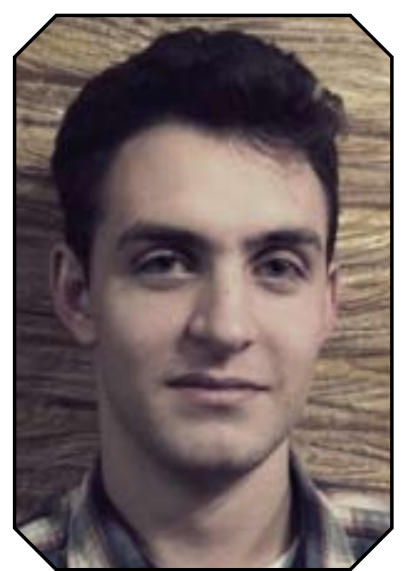

\section{НОВИКОВ Глеб}

Евгеньевич -

студент бакалаврской

программы

«Социология»

фракультета социальных

наук; лаборант

Лаборатории экономико-

социологических

исследований

Национального

исследовательского

университета «Высшая

школа экономики».

Адрес: 101000,

Россия, г. Москва,

ул. Мясницкая, д. 20.

Email: nov.gleb.evg@ yandex.ru
Новый сезон еженедельных семинаров Лаборатории экономико-сочиологических исследований стартовал 6 сентября 2016 г. Докладчиком на первом семинаре выступил заведующий лабораторией и первый проректор НИУ ВШЭ, д. э. н. В. В. Радаев. Его выступление было посвящено проблеме связи отдельных эмпирических исследований с крупными темами в сочииологии. Радаев предложил искать темы, которые, с одной стороны, не оторваны от эмпирической реальности, а с другой - связыввают множество разнородных объектных сфер. В качестве примера такого подхода был продемонстрирован проект исследования, где значительное снижение объёма потребления алкоголя поколением Millennials (родившиеся в 1982-1999 г2.) связывается с более масштабными социальными сдвигами и, возможно, свидетельствует о постепенном уходе «советского простого человека» с позиичи доминирующего сочиильного типа. Потребление алкоголя было выбрано в качестве индикатора, поскольку этот товар тесно связан со множеством сфер жизни - со здравоохранением, политикой, экономикой, повседневной коммуникацией и др. Проблема заключается в том, что поколения, предшествующчие Millennials, при скудном предложении и плохом качестве алкогольной продукции потребляли и потребляют её примерно в два раза больше, чем Millennials, хотя общая ситуация для них значительно лучше. Применив когортный анализ для описания этого парадокса, В. В. Радаев объяснил его крупными сочиокультурными изменениями в постсоветской России.

Доклад вызвал оживлённое обсуждение, которое затронуло как методическую сторону исследования, так и его общеметодологическую направленность. В обсуждении приняли участие сотрудники ЛЭСИ Е. С. Бердышева, Д. Х. Ибрагимова, А. Б. Круглова, О. Е. Кузина, А. В. Шевчук и др., а также студенты НИУ ВШЭ.

Ключевые слова: крупные темы; индикаторы; алкоголь; «советский простой человек»; поколения; когортный анализ; социальный сдвиг; миллениалы.

Новый сезон еженедельных семинаров Лаборатории экономико-социологических исследований начался с методологического семинара, посвящённого тому, как связать отдельные эмпирические исследования с крупными темами в социологии. Докладчиком выступил д. э. н., профессор, заведующий кафедрой экономической социологии и ЛЭСИ, первый проректор НИУ ВШЭ Вадим Валерьевич Радаев. 
В социологии, а возможно, и во всякой науке, исследователей поджидает ряд разочарований, о которых все знают, но с которыми тем не менее очень многие не могут справиться. Это, с одной стороны, абстрактные псевдотеоретические рассуждения «об обществе», с другой — накопление «сырых» фактов без попытки встроить их в сколь-либо широкий теоретический контекст. Происходит и замыкание исследователей на достаточно узких областях социологического знания. Иначе говоря, существует некая периферийная тема, есть десяток человек, которые ею занимаются, они отлично друг друга знают, делают доклады друг перед другом, не выводя обсуждение за рамки этой темы. Социологи, специализирующиеся на других областях, не читают их работ, поскольку сама по себе тема для них нерелевантна, сами они друг друга тоже не читают, потому что и без того знают и свою область, и тех, кто ею занимается. «И поэтому наши тексты никто не читает», - иронично отметил Радаев.

Пафос доклада заключался именно в том, чтобы найти способ избежать всех трёх разочарований. В. В. Радаев предложил двигаться с двух сторон: искать «индикаторы-ключи» - конкретные эмпирически измеряемые показатели, которые помогают открыть двери к крупным темам. Закономерно возникают два вопроса: что может служить таким индикатором и что понимается под «крупными темами»?

В качестве примера индикатора-ключа Радаев привёл уровень потребления алкоголя, пояснив, что алкоголь, в отличие от большинства стандартных товаров, порождает зависимости, является объектом специальной политики государства и регулируется отдельным министерством, теснейшим образом связан со здоровьем, с образом жизни и смертностью, а также может выполнять дополнительные функции повышения статуса, средства обмена, символа определённых отношений - список можно продолжать. Неотъемлемость алкоголя от российской культуры и повседневной коммуникации ясна даже на обыденном уровне.

Отвечая на вопрос, что же такое крупная тема, Радаев в первую очередь отметил, что это не общие рассуждения, не гранд-теория, не большой компаративный проект на несколько стран и не междисциплинарное исследование. Хорошим примером крупной темы может служить «советский простой человек» - социально-антропологический тип, изучением которого с 1989 г. занимался Ю. А. Левада, а затем - ряд исследователей из Левада-центра, в частности, Л. Д. Гудков [Левада 1993].

«Советский простой человек» - это идеальный тип человека, охватывающий как поведение, так и область символического производства. Кроме того, это нормативный образец, на который ориентируются значительные массы общества. Понятие «советский простой человек» больше, чем эмпирическое обобщение, это социальный характер, релевантный для множества стран тоталитарного и постсоциалистического режимов и экономических систем, проходящих незападные варианты модернизации.

Основными характеристиками этого социального типа являются представления об исключительности «нашего» народа, о «принадлежности» государству, уравнительные установки и сочетание превосходства с ущемлённостью. Образец соединяет несоединимое: приемлемость контроля и постоянные попытки его избежать, эгалитарность и иерархичность, имперские амбиции и примитивные запросы на уровне выживания. Интересно, что такая противоречивость «работает» в обе стороны: государство получает огромные возможности для манипуляции населением, но в то же время и люди могут использовать тех, кто обладает властью, для своих личных нужд. Таким образом, принуждение становится взаимовыгодным.

Если описанный социальный характер устойчив, то существуют и механизмы его воспроизводства на уровне социализации, социального контроля, санкций. Масштабное исследование, анкетный опрос объёмом 200-300 вопросов, многократно повторявшийся начиная с 1989 г., позволил Ю. А. Леваде и 
его последователям выдвинуть весьма обоснованную гипотезу, состоящую в том, что «советский человек» пережил 1980-е и 1990-е гг, несмотря на распад СССР и радикальные изменения, политические и экономические (см. подробнее, например: [Гудков 2007]).

В. В. Радаев выдвигает другую гипотезу: «советский человек», переживший радикальные изменения 1980-1990-х гг., не выдержал испытания «сытыми и спокойными» 2000-ми, поэтому теперь мы имеем дело с принципиально новым типом человека. В поколении, вхождение которого во взрослую жизнь пришлось на 2000-е гг., не отмеченные радикальными экономическими или политическими преобразованиями, произошёл социальный перелом, коснувшийся многих сфер жизни. Конечно, у этой гипотезы нет такой мощной доказательной базы, как у гипотезы о «советском человеке», подкреплённой данными более чем 20-летнего исследования. Однако определённые основания у неё есть: если признать, что некоторые индикаторы (в данном случае потребление алкоголя) прочно связаны с целым рядом областей социальной жизни, нужно признать и то, что значительные изменения в этих индикаторах отражают изменения сразу в нескольких областях, а возможно, и во всей социальной жизни (в данном случае это изменение - формирование нового социального типа).

Как связать такие, казалось бы, разные темы, как потребление алкоголя и поколенческий анализ? Как построить мост между частным индикатором и крупной темой? Радаев обращает внимание, что потребление алкоголя начинается в большинстве случаев, когда человеку исполняется 17-22 года: алкоголь является важным атрибутом взросления - как юридического, так и социального, что и даёт возможность, говоря об алкоголе, делать выводы о культуре, образе жизни и в какой-то степени о социальном типе.

Чтобы проследить возможные изменения в уровне и характере потребления алкоголя, Радаев проводит когортный анализ, сравнивая не людей одних и тех же возрастов в разное время, а людей, родившихся и выросших в разное время и в разных условиях и достигших к настоящему моменту разного возраста. Радаев выделяет пять поколений относительно периода, на который пришлось взросление (17-25 лет), — это сталинская эпоха (1945-1956 гг.), хрущёвская оттепель (1956-1964 гг.), брежневский застой (1965-1984 гг.), 1985-1990-е гг. и 2000-е гг. Поколение, взрослевшее в 2000-е гг., он называет Millennials, и именно с ним связано очень серьёзное изменение в объёме потребления алкоголя. Если два предыдущих поколения, невзирая на скудный ассортимент, плохое качество, антиалкогольные кампании, потребляли алкоголь в весьма больших объёмах (200 г чистого спирта на человека в месяц и более), то у поколения Millennials, несмотря на рост как предложения, так и качества, уровень потребления упал примерно в два раза, и этот разрыв сохраняется между поколениями и в настоящее время (по данным «Российского мониторинга экономического положения и здоровья населения НИУ ВШЭ» - RLMS-HSE).

В итоге потребление алкоголя оказывается хорошим индикатором, позволяющим перейти от наблюдаемых трендов к масштабным социокультурным сдвигам. А резкое снижение уровня потребления алкоголя в поколении Millennials, продемонстрированное Радаевым с помощью нескольких графиков, становится одним из частных, но важных свидетельств более масштабных социальных изменений.

Дополнив доклад ещё одним примером, связанным с увеличившейся самооценкой социального статуса у молодёжи, Радаев перешёл к обсуждению темы с теми, кто пришёл на семинар, а их оказалось довольно много: поточная аудитория была заполнена.

В вопросах и комментариях тоже не было недостатка. Так, Ольга Кузина отметила, что высокое потребление алкоголя «старшими» поколениями могло быть вызвано его дистанцией (труднодоступностью), которая увеличивала и ценность. Теперь же, когда алкоголь больше не является запретным плодом, его 
место в потреблении могли занять наркотики или компьютерные игры. Ещё одну гипотезу предложил Андрей Шевчук, заметив, что в современной России существенная часть алкогольной продукции потребляется не дома, а в ресторанах, кафе и других публичных местах. Однако Вадим Радаев выразил сомнение в том, что эти изменения действительно могут объяснить столь резкий перелом.

Диляра Ибрагимова обратила внимание на трудность, которая напрямую следует из выбранных для сравнения категорий: сравнительный кросс-секционный когортный анализ объединяет эффекты возраста и времени, и возникает большая проблема: как их разделить?

Были предложены несколько дополнительных индикаторов, которые вместе с уровнем потребления алкоголя могли бы отразить социокультурный сдвиг, так изменивший поколение выросших в 2000-е гг. Анна Круглова указала на то, что в последние годы радикально изменились практики воспитания: родители больше не «давят» на детей; наоборот, они всячески их поддерживают и становятся им «лучшими друзьями». В такой ситуации необходимость трансгрессивных практик (таких как употребление алкоголя), которые можно проследить через всю мировую историю, ставится под вопрос. Если новое поколение больше никто не принуждает к определённому поведению, периодические «побеги» из-под контроля общества и в самом деле не нужны. В этом смысле, действительно, можно говорить о совершенно особых характеристиках поколения Millennials, отличающих его от всех предшествующих. В качестве ещё одного индикатора было предложено заметное снижение религиозности и нарастание атеистических тенденций в современной России.

Были и другие замечания, связанные с методологией; в большом количестве выдвигались гипотезы о причинах снижения потребления алкоголя. Задавали вопросы и делились мнениями не только коллеги по лаборатории, но и студенты, в том числе первокурсники.

Ближе к концу семинара Елена Бердышева заметила, что на самом деле проблема разочарований, с которой Радаев начал доклад, уже имеет вполне конвенциональное решение, а именно отнесение исследований к базовым для социологии темам, которые в работах классиков имеют как теоретическое обоснование, так и связи между собой. Ольга Кузина в ходе обсуждения также отметила, что к интерпретации фактов можно подходить и с понятийной точки зрения, связывать их не с крупными темами, a с той или иной теорией. Вадим Радаев ответил, что, действительно, это возможные подходы к решению проблемы; есть и другие - например, рассмотрение совершенно разных объектов при помощи определённого метода (допустим, сетевого анализа). Но смысл доклада заключался в другом - показать, как можно, занимаясь фактически любой темой, протянуть нить к общезначимым проблемам, сделав исследование более глубоким и поборов разочарования от замыкания на мелких темах и абстрактных рассуждениях.

В завершение семинара Вадим Радаев обозначил перспективность обсуждаемых вопросов и поздравил первокурсников с поступлением.

\section{Литература}

Гудков Л. Д. 2007. «Советский человек» в социологии Юрия Левады. Общественные науки и современность. 6: 16-30.

Левада Ю. А. (отв. ред.). 1993. Советский простой человек: Опыт сочиильного портрета на рубеже 90-x. М.: Мировой океан. 


\title{
CONFERENCES
}

\section{Gleb Novikov}

\section{Should Big Topics in Sociology be Studied?}

\section{Seminar of Laboratory for Studies in Economic Sociology, September 6, 2016, Moscow, Russia}

NOVIKOV, Gleb - BA

Student, Faculty of Social

Sciences; Research Assistant, Laboratory for Studies in Economic Sociology, National Research University Higher School of Economics. Address: 20 Myasnitskaya str., Moscow, 101000, Russian Federation.

Email: nov.gleb.evg@yandex.ru

\begin{abstract}
The new season of weekly seminars of the Laboratory for Studies in Economic Sociology started on September 6, 2016. The department head and first vice rector of HSE, Vadim Radaev, was a speaker, and his presentation explored links between concrete empirical studies and "broad topics" in sociology. Radaev suggested looking for topics that are not separate from empirical findings and connect many subject areas. A draft research project was considered as an illustrative example. The point was to relate a decrease in alcohol consumption by Millennials (those born in 1982-1999) to larger-scale social shifts and potentially to the withering away of a "Soviet common man" from the position of a dominant social type. Alcohol
\end{abstract} consumption was chosen as an indicator because of its close relationship to multiple life spheres: healthcare, politics, economy, everyday communication, etc. The paradox is that despite enjoying favorable conditions for drinking, Millennials consume about two times less alcohol than previous generations. By applying a cohort analysis to illuminate this paradox, Vadim Radaev attributed it to massive sociocultural changes in post-Soviet Russia.

The presentation included a lively discussion of both methodical issues and general methodological considerations. The discussion was carried out by laboratory researchers Elena Berdysheva, Dilyara Ibragimova, Anna Kruglova, Olga Kuzina, Andrey Shevchuk, and numerous HSE students.

Keywords: big topics; indicators; alcohol; simple soviet man; generations; cohort analysis; social shift; millennials.

\section{References}

Gudkov L. D. (2007) "Sovetskiy chelovek" v sotsiologii Yuriya Levady [“Soviet Man” in Sociology of Yuri Levada]. Obshchestvennye nauki i sovremennost', no 6, pp. 16-30 (in Russian).

Levada Y. A. (ed.) (1993) Sovetskiy prostoy chelovek: opyt sotsial'nogo portreta na rubezhe 90-kh [Common Soviet Man: An Essay of a Social Portrait at the Turn of the 90s], Moscow, Mirovoy okean (in Russian).

Received: September 8, 2016.

Citation: Novikov G. (2016) Nuzhno li zanimat'sya krupnymi temami v sotsiologii? [Should "Big Topics" in Sociology be Studied?] Laboratory for Studies in Economic Sociology's Seminar, 6 September, 2016. Journal of Economic Sociology = Ekonomicheskaya sotsiologiya, vol. 17, no 4, pp. 201-205. Available at: https:// ecsoc.hse.ru/2016-17-4.html (in Russian). 


\section{INTERVIEWS}

\section{Interview with Gabriel Abend: "The Moral Background Makes the Play of Life Possible"}

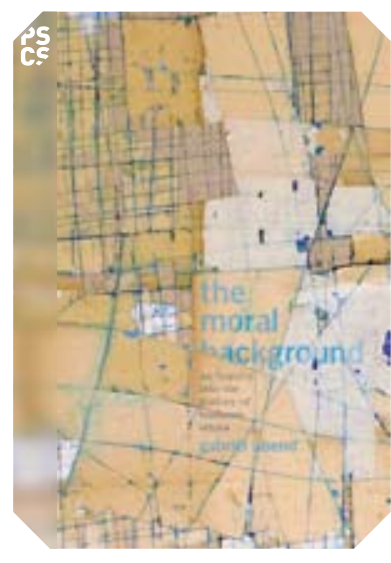

ABEND, Gabriel Associate Professor of Sociology, New York University. Address: 295 Lafayette Street, New York, NY 10012-9605, USA.

Email: abend [at] nyu [dot] edu
Gabriel Abend, Associate Professor of Sociology at New York University, was interviewed during his guest visit at National Research University Higher School of Economics. He gave a presentation entitled, "The Moral Background: An Inquiry into the History of Business Ethics", based on his recent book of the same name. The interview was prepared and conducted by Elena Gudova, Ph.D. student and teacher at Higher School of Economics.

\begin{abstract}
Gabriel Abend discusses his interest in the sociology of morality and the main ideas of his book The Moral Background: An Inquiry into the History of Business Ethics [Abend 2014]. According to Abend, the business ethics discipline and its growing popularity at business schools deals not only with the tension between making money and being ethical, but with the preconditions which enable moral life: the moral background.
\end{abstract}

Abend states that studying moralities and moral action in the social sciences is usually viewed through the lens of the first one, behavioral level, and the second one, normative level (moral and immoral behavior and norms, respectively), which, taken together, constitute first-order morality. Abend also points out that the "moral background" should be suggested as the third level, or second-order morality, which underlies and supports first-order morality through six dimensions. These include: the reasons for first-level morality support, the existing concepts repertoire, the subject of the moral evaluation, proper moral methods, the objectiveness of morality, and metaphysical conceptions. Some of these dimensions have a society-level organization, such as the conceptual repertoire for speaking about moralities in different languages, and some dimensions have an individual-level organization, such as the objectivity or relativity of first-order morality.

Abend identifies two types of moral background that he describes as the "Christian Merchant" and the "Standards of Practice". The "Christian Merchant" type can be characterized as an ethics of being, developing certain features of character and moral objectivism. The "Standards of Practice" is an ethics of doing, which sustains moral relativism and emphasizes moral actions with no particular attention to their motives. The "Standards of Practice" type has found its way into business schools' curricula as a business ethics discipline that believes morality can be taught by using case studies. This approach, while maintaining the principles of corporate social responsibility, can have negative effects on society and the economy. As long as corporations suggest that ethics pays and act morally only to make a profit, there is a risk that without the payoff, they will stop acting morally. This fact causes questions to surface, not only about corporate 
social responsibility and ethical behavior in business, but ultimately about values and the place of morality in society at large.

Keywords: business ethics; business schools; moral background; economic sociology; cultural sociology; sociology of morality.

— Gabriel, as for the beginning, could you please tell something about your background. How did you come up with the idea of business ethics?

- I think I began with an interest in the sociology of morality. I'd been long interested in ethics, in philosophical ethics, and at the same time I wanted to do something related to ethics from a sociological perspective. Then I was looking for an empirical site, for empirical data, where I could fruitfully think about the sociology of morality, what it would be like to study morality sociologically. I even had some other small projects at the time, as I was doing my Ph.D. For example, one summer I went to France to the National Library to look into the problem of moral education, how teachers teach children to be moral. At some point I realized that this project wasn't going to work out. So, eventually I came across business ethics as a thing in the business school at Northwestern University. I was not fully aware of business ethics before, I don't think back home in Uruguay I'd ever heard of it. I was surprised that there was a class in business schools called "business ethics". At the same time, I was starting to see companies talk about their social responsibility actions. I was learning about these things and I thought it was interesting because of the tension between making money and being ethical. That's probably what strikes you at the beginning. Why don't these companies try to increase their profits only, but instead they also care about the community_or that's at least what they're saying? This seemed to be a good area to study for a sociology of morality project.

\section{— Is there a difference between social responsibility and business ethics? Because at some points they overlap, and at some points they are completely different. What is your idea about that?}

- Well, there are two things here. The first one is how these expressions are used now in English. They have different meanings. Corporate social responsibility (CSR) is more specific. The idea is that corporations have duties, which are social in the sense that they are owed to society and social actors. In a way, it is a positive thing that you need to do. You ought to contribute to and not harm the community from which you extract your wealth. It is specific about corporations, having specific kinds of duties, which they should do or should not do. Business ethics is broader and is also a discipline, so if you have a class in a business school, then it's going to be called business ethics. It will cover CSR and other things, which also touch on ethics.

The expressions have a history. You can find a lot of examples of what we would now call "corporate social responsibility" a hundred years ago, but you don't find the expression "corporate social responsibility." This is a fancier term that at some point in history came up. You can look at usage examples in different ways and in databases of books, newspapers, and see when the term emerged. "Business ethics" is older, but again, before the words "business" and "ethics" came together, people were talking about the morals of trade and commercial morality in the nineteenth century... This is all in the English language, but in other languages we need to look for other words. The subtitle of my book is "An inquiry into the history of business ethics" because it is the broader term, but I include in it corporate social responsibility, or at least what we mean now by it, projected onto the past.

- As you have touched the subject of your book, could you please introduce the readers to it? Main ideas, things that have inspired you, the method. 
- This was a book long in the making; I worked on it for many years. One version was my dissertation in 2008 , but the book really has very little to do with the dissertation. I have collected much more historical data about business ethics than what appears in the book or than I could ever use in my life.

When I started writing the book from scratch I had basically two aims. The first was to make a contribution to the sociological study of morality in general, so I wanted to address the sociology of morality and also other disciplines that concern themselves with morality. This includes anthropology, psychology, neuroscience, and even economics in some parts of it. Basically, any scholarly activity that is interested in morality. I wanted to say something interesting and useful to all these people and not limited to business in particular. This part of the project I imagined as something that could be helpful whenever you were interested in morality. I call it the conceptual project, or conceptual framework. As for the other aim I had, that's the historical part of the project. It's a historical sociology focusing on the second half of the nineteenth century and first few decades of the twentieth century in the United States. This is where the historical documents are from; this is what the historical narrative is about; and so on. The way in which I give this account is through the lens of the moral background concept. I claim that the moral background is a tool for empirical research; for example, to give an account of the development of business ethics in the U.S.

Let me try to summarize these two aspects. The conceptual project makes a distinction between three levels of morality. There are people studying moral behavior and that's very important and good that it's being done. There are people studying norms, moral beliefs, moral institutions; I call that the normative level and there is a lot of research about that, too. ${ }^{1}$ And I want to identify a third level, which I call the moral background, and I say that the moral background is that which enables moral life, makes moral life possible. It underlies the other two levels. ${ }^{2}$

One metaphor that I use sometimes and some people find helpful has to do with theatre. When you show up to the theatre, the play starts at, let's say, 7:45 p.m., and the play begins. Assume that the play is the moral life. If your research focuses only on the other two levels, on the behavioral level and the normative level, which is actually what's being done, it is like focusing on what happens when the play begins. The idea of the moral background is that some things happen before the beginning of the play, which make it possible that the play takes place the way it does. The most obvious one is that there were rehearsals. But there are also material objects that were built in order for the actors to use, there was also the writing of the piece, and the lights put in the place where they are, and the stage that was designed, and so on. So, the moral background looks at all these things, which are perhaps invisible until you reflect on them. They are not literally invisible, because you can see them, but what is invisible is the fact that they were put in place beforehand. They are the conditions of possibility of the play's happening in the way it does.

In the case of morality there are basically six dimensions of this moral background ${ }^{3}$, the way I see it. I'll give you one example, the easiest to explain. It so happens that a community has a particular repertoire of moral concepts. It's like a menu of concepts that exist in culture, which you can make use of if you want. But you didn't invent them, they are given to you, and they shape what you can do. So, if you say that a certain fac-

1 On recent behavioral-level and normative-level research, see [Bazerman, Gino 2012; Hitlin, Vaisey 2010; 2013; Treviño, NieuwenboerN., Kish-Gephart 2014; Simpson, Willer 2015].

2 "The moral background is the set of second-order elements that facilitate, support, or enable first-order morality. By "secondorder" I mean that they do not belong to the realm of first-order morality; they do not belong to the realm of moral claims, norms, actions, practices, and institutions. Rather, they are "para-moral" elements: they are ancillary or auxiliary to morality" [Abend 2014: 16].

3 These are: "(1) the kinds of reasons or grounds that support first-order morality; (2) conceptual repertoires; (3) what can be morally evaluated; (4) what counts as proper moral methods and arguments; (5) whether first-order morality is assumed to be objective; and (6) metaphysical conceptions about what there is and what these things are like" [Abend 2014: 17]. 
tory is exploitative, the concept of exploitation is something you are making use of, you're taking it from the repertoire. You can have discussions about it in a bar or in the congress of a nation. And many consequences follow from our identifying a certain factory, person, or behavior as exploitative, and obviously there are disagreements as to what counts as exploitation or normal work conditions. All these things are part of our moral life. People discuss, fight, lose; books and articles are written ... All of this is made possible by the fact that there is a concept of exploitation. The fact that there is a particular conceptual repertoire that we can make use of is a feature of the moral background.

What is important to say here is that not all societies, not all languages, have the same repertoire. There are hundreds of languages and historically there were many more, and not all of them have the same concepts. I don't want to get into to what extent that's the property of a language, like the Russian language, the Spanish language, and to what extent it's the property of a society or culture, and what exactly is the relation between the two.

This was just an example, something that in the theatre metaphor is happening before the play.

\section{- What is the genesis of these concepts in different languages and the other five dimensions of moral background? Were they consciously constructed or was it just a reproduction of previous social order?}

- It's true that these things are, in some sense, created, and it's partly true that they are not created by a designer intentionally. It's an interesting question, but it's better to focus on other dimensions of the moral background for this. So, one dimension is called metaphysics, and the basic idea is simply this: it is what the members of a society take there to be. For example, if you live in a religious community, you will take there to be a God or gods, but also that people have souls. And maybe if you live in a certain kind of community, you will take there to be something beyond the material objects and particles that physicists study. Any of these things, which fall plausibly under metaphysics, it's not that they were invented by a king or president, but something that has developed historically. In this case it sounds like it's not intentional.

I'll give you one more dimension as an example. There is another dimension of the background that's called moral method and argument. Take a certain society or community or group and say they have a discussion about a moral issue. Suppose they are discussing whether abortion is morally acceptable or not. There are only certain ways in which people can go about making a claim in the context of a moral argument. So, if you said, for example, let's just decide this by raising our hands, the response would probably be, "Look, moral matters are not the kind of thing where you just vote, like elections in democracy." This is just like in science: there are only certain methods that you can use. Moral methods are slightly metaphorical in that, it's not some formal procedure like the scientific method. Rather, if you don't do this, others will shrug their shoulders or look puzzled and say, "What are you doing?" So, that's another example. It's not intentional, it's just the development of institutions, the development of cultures, and so on, and only certain methods end up being valid. Again, I gave you an example where it sounds like it's not intentional. These moral background dimensions are in some sense the product of spontaneous developments.

\section{— Spontaneous development of a single person or can you say they are applied by the society?}

- We have to consider to what extent moral background dimensions are properties of individuals or properties of groups or societies. By which I mean, if you should measure it or observe it at the level of individuals, or you should observe it at the level of groups or societies, more in a Durkheimian way. And this is tricky, because I don't think the six dimensions of the background are alike.

— Can you give an example of an individual-level dimension and a society-level one? 
- Let's start with an individual-level example. One background dimension is whether people take their morals to be objective or not, whether they take a claim about morals or a discussion about morals to have a right answer in the sense of, for example, who is at present the president of Uruguay. Here there is a fact of the matter. You may know it or you may not know it, but if two people make different claims about who is the president of Uruguay, someone will be mistaken. They may both be mistaken, but there is a fact of the matter and people would agree that there is a fact of the matter, which is not up to us. By contrast, consider the case of taste, food (though this is contentious). Suppose there is a disagreement about whether something is delicious or disgusting, say, Brussels sprouts, or mustard. Someone says mustard is the most delicious thing you can possibly add to your dish, while someone else is disgusted by it and says that it ruins whatever you are eating. These people don't think there is a fact of the matter about this: is mustard objectively delicious or objectively disgusting? They just take it that they have different feelings about mustard; it's a matter of taste. We have facts of the matter about who is the president of Uruguay and we have things that are subjective or opinions or something like that.

So, this dimension of the moral background asks: look at these people here, or look at this guy, this group, or this society, how they understand their morals. Do they think that their discussions have the same status as discussions about which there is a fact of the matter, so that someone is mistaken and someone is right? Or do they think that there is nothing to agree on because that is just a relative issue? It might be a good or morally good thing for you, but it's a bad or morally bad thing for me, and there is nothing more to talk about. The first group of people will be moral objectivists, and the second group might be either moral relativists or moral subjectivists. Now, is that a property of a society? Is that a property of a group? Is that a property of an individual? I think you'd have to say it's a property of the individual, because maybe in some society everybody agrees that these are morally objective things, but it doesn't need to be so. If you ask different people, some people would say that moral questions have objective answers, but some people would say that there are no objective answers. This is a dimension where you will have to look at individual-level variation. You don't want to say that the whole society is subjectivist; all you can say is that there is a majority, just like any other individual-level property.

\section{- What with the issue of power in that situation? Because there can be opinion leaders or people who are in charge of resource distribution, for example.}

— This is similar to the explanation of other kinds of belief. It falls within what sociologists of knowledge try to explain. It is in the interest of certain people and organizations that certain beliefs be held, and that applies to any kind of belief, including political and moral beliefs. You may find a distribution where some people believe A, some people believe B, some have belief $\mathrm{C}$, and then powerful groups push for $\mathrm{C}$, and there is a majority of the population that end up supporting that. But the property is still individual. The unit of analysis that you are looking at is individual. Then you add them up and it turns out that $80 \%$ of the people believe C.

\section{—What about the society-level dimension?}

- An example that I've already given may be again the easiest to explain here. A conceptual repertoire just can't be an individual property. It's not like you explicitly say, "Yes, there is this list," but rather, if you don't use a concept that makes sense in a particular context, people don't understand you. The repertoire is there and it changes over time. But however the process exactly is, at any given point in time, the repertoire belongs to the collective, to whoever are members of this conceptual community. It doesn't need to be a society as a whole. It's not necessarily a whole country or language. It might be a smaller social group, professional associations or groupings, or even academic, scholarly communities. 
- You have to talk about one element or dimension of this group's background, they have a specific conceptual repertoire, they can use certain concepts that others can't.

-Mitchel Abolafia, when writing about brokers and financial markets, introduced the concept of "local rationality". The basic idea is that you may have as many local rationalities as you have professional groups, or special subcultures. But in the case of the concepts, if they have different concept schemes, will that make them belong to different moral backgrounds?

- You don't want to essentialize these things, as if it were, you have this moral background, you have that background. Look at it methodologically. Suppose you have a historical document, a text. You are a historical sociologist, as I happen to be in this book. You have a sermon that was delivered in 1910 in New York City. The text is printed, and we still have it, and we can read it. What happens in reality is that you can find within one person, even within one single text, elements that belong to different categories of moral background dimensions. People are not consistent necessarily. People are not philosophers, obviously, and you don't want to say this person belongs to this moral background, as if it was a box they had to be in. If you want to be true to reality, you want to say something like this. My book presents two types of moral background. You examine many historical documents and the same texts may have elements of both. Still, as a whole, one text may have more of one type of moral background than of the other.

\section{— Could you please tell a bit more about behavioral and normative levels of morality?}

- That's easier to explain. An example of research about the behavioral level is social psychology experiments that try to understand what makes people more likely to help [Isen, Levin 1972; Penner et al. 2005]. There is a tradition of research about that, and what we are interested in here is helping behavior; for example, helping someone who is in need. Another example: an ethnographer might go and observe with his or her own eyes to what extent people help each other, in which places and situations, which has the disadvantage that it's not a controlled experiment, but it has the advantage that it's real life.

\section{— It doesn't limit to the biology, right?}

- No, any behavior, in the sense of people actually doing things; this is not about thoughts and beliefs or anything in the mind. Take cheating from the behavioral level perspective. It's not what people say about cheating or what people believe about cheating, nor what institutions and laws are about cheating, but whether, how much, where, who is more likely to cheat, and why.

\section{- What about the normative level?}

- The normative level includes a few more things in it. It includes individuals' moral views or moral convictions, or you may say their moral beliefs, or even moral values if you like that terminology. An example of a normative-level research project: you ask people what are their moral views, on abortion for example, whether it's always wrong, sometimes wrong, etc. And why they think it is wrong, which usually requires an extended interview. You are getting at what they think about it in some way. Then you may do research that tries to connect the behavioral level to the normative level, to see what the relationship is between what people believe and what they do. That's one part of the normative level: what are people's moral views or convictions. Another part is society's norms and institutions, which are in some way dependent on individuals. But you may believe, like Durkheim, that they are sui generis, so they go beyond individuals. They are more than the sum of individuals' views. If you were a normative-level researcher, you'd want to see in a community what norms exist, if people who go against them will be sanctioned. Other people will try to prevent them from doing things that go against the norms or get legal or social punishment for those who did go against the norms. 
In sum, about both of these levels, normative and behavioral, there's a lot of good research. My argument is that something is still missing, another aspect of morality. That's the moral background level.

\section{- You also distinguish two types of business ethics, the "Christian Merchant" and the "Standard of Practice". Could you please tell more about them?}

- The book first presents a conceptual framework and then uses it to look at the history of business ethics in the U.S. It does so in several ways. One is focusing on the idea that business ethics is good business, that being ethical pays. But another one presents two types of business ethics from the moral background point of view. The difference here is specifically at the level of the background. This is important because at the level of firstorder morality, at the level of norms and prescriptions, they don't differ at all. All business ethicists will roughly say very similar things as far as prescriptions go. They will say, "Okay, you should do this, you shouldn't do that." They speak against different kinds of fraud and corruption, etc. But my argument is that although they are saying the same at the normative level, they differ at the background level. This can be summarized with this typology: one type I call "Standards of Practice" and the other type I call "Christian Merchant" (these are just the names I gave them). These types differ in all six dimensions of the moral background.

Here's one example of their differences. What is the central question that ethics in general and business ethics in particular are about? The distinction here sometimes is called a distinction between "ethics of being" and "ethics of doing". The way this shows up in the philosophical literature is this. When some philosophers or ethicists write a book about ethics, they will focus on action, what's okay to do, what you should do, what you shouldn't do. That's doing, what you might call the ethics of doing. Other philosophers are much more interested in what you should be or what you should become, if you are not that yet. The question is what kind of person you should be and then the emphasis may be on certain character features. They may apply to actions, but mostly apply to persons. That's why it is an ethics of being. Aristotle is typically thought of as the main example of the ethics of being, and some Christian ethicists and theologians are also inclined to ask these sorts of questions. For instance, you should be a loving person; so, the virtue of love should be developed. And they don't focus on specific actions and specific situations, these are not the main objects, this is not the central question of ethics. By contrast, if you look at modern moral philosophy, especially analytic, a very important part of ethics is about actions and situations. These modern moral philosophers start with situations in which there are two or more options that an agent may go for. And they try to figure out what's the morally right option and also how you would know that: what rule, what principles, what procedure the agent needs to follow to determine if she should go for $A, B$, or $C$.

This is the conceptual distinction between ethics of being and ethics of doing. Then, I turn to the history of business ethics, sociologically, and I find something like this distinction. There are business ethicists who focus more on ethics-of-being questions, which are more likely to be ministers, but not only. Whereas for others, such as many business school professors, you find a lot of ethics-of-doing questions, and not so much emphasis on ethics-of-being questions.

\section{- Can we say that the issue is that you cannot teach how to be ethical; you can only teach how to do ethical things? That is the question of knowledge?}

- I think that might explain why someone faced with the task of teaching a class that meets only a couple of times a week or a month will want to use concrete cases. And this makes sense. On the other hand, usually the people who are virtue ethicists, they tend to think that you need to be brought up to be a certain way. Character traits are more permanent and they need to be cultivated when you are young. It's too late when talking to students in the university classroom. They should be brought up in the right way in their families or primary schools. 
There are issues that are more contingent in the particular case of teaching in business schools. This story has to do with the university itself, how the case method became a way of teaching ethics, why the case method was used in business schools in general, and where it came from. Which in turn has to do with the relations between business and law schools; there was an analogy between business cases and legal cases.

\section{—Why should we care for the motives when a person or a company still acts ethical?}

- Suppose you have the same action, and when you ask the person, "Hey, why did you do that?", you get this response, "Oh, because it's the right thing to do." But someone else responds, "Well, because I will make money out of it." The example here is usually corporate social responsibility. The question is if it was done because it's the right thing to do - to help these people here or there-or it's because more people will buy your product if they know you are doing it. You ask me whether it matters what reason they have to do it. I guess the answer depends on whether it matters to whom. Because if you are a legislator, if you are interested in this from the point of view of the state and the public good, the good outcome is already a good thing, you may or may not be so concerned about the moral foundations and motives of individuals. If you are an ethicist, it will depend on what kind of ethicist you are. The Kantian ethicist will say, "Look, this is just not right, not okay, the good action has to be done out of the right motives, otherwise it doesn't count." But if you are, by contrast, a consequentialist, which is a different school, you will not care about the motivations of the agent, you will be satisfied with the good consequences.

But I also want to say that if you are thinking from the perspective of the state and the public good, and you want corporations to be good, and businesspeople to be honest, then you may not be fully satisfied with actions that are performed from the wrong motives. The reason is that that's not very reliable. You may do something good, because it pays today. But if tomorrow it doesn't pay, you won't do it anymore. Moreover, there is the risk that people will not do good things but only pretend to do good things, which is a basic Machiavellian move. It's not important whether you are really good, but what is important is that everybody thinks you are good. But if people are doing it because they have an internal, a true belief that it's the right thing to do, their moral behavior is more reliable.

\section{- There are situations in business schools where teachers might ask you to do this because ethics pays. But doing and teaching to do ethical things is also subjective... Is there any foundation, a common ground, except religion maybe or except some world values?}

— First, one thing about your first point. It's true and it's important to emphasize that, as a matter of fact, what happens is that most business ethicists will not say that it's either from the right motives or to make money thereby, but both. So, as you're free to combine them, there is a seemingly very good solution for business ethicists. They can say, "Look, do this, don't cheat, help your community, care about your stakeholders, as people say these days: it's both the right thing to do and it will make a difference to your bottom line." So, great! It's the best possible world. Whether this is true or not is a separate question. This is your first point. I think your second point isn't a question so much for the sociology of morality as it is a question for metaethicists, for moral philosophers. There you might ask on what grounds there can possibly be an agreement about it. But who knows, maybe there is moral truth and it's not religious. This is really a philosophical question.

Durkheim was proud of making a distinction between what philosophers do and what sociologists do. This is in The Rules of Sociological Method [Durkheim 1982]. Another of the founders of sociology, Max Weber, emphasized the idea of scientific sociology. He couldn't tell students what they should do, what kind of life they should lead. This is a value question that sociology can't resolve. Yet, at the same time, the discipline of sociology has always wanted to have a normative impact on society, and that requires that you don't merely remain in the world of facts, but say something about how the world should be. For example, you may say 
"Poverty is a bad thing"; "Inequality is a bad thing". And the sociologist can help you to redress inequality, make things less unequal, decrease gender or racial discrimination - all these things that seem to be in the realm of morality. But someone could potentially come along and say, "Well, no, discrimination is not bad." What you are going to respond then? I mean, you might say, "We all agree that it's bad to discriminate on the basis of gender and race." But this person will respond, "That's your subjective opinion." The history of sociology (and the social sciences in general) is marked by this tension. Trying to be scientific has seemed to some people to mean that you have to give up on values and ethical and philosophical questions like that.

On the one hand, sociologists of morality think they study moral questions and many of them take the standard scientific line, saying, "Well, I study values, I study philosophical ethics issues, but as a scientist, so I don't address these issues themselves." On the other hand, there is a movement, which has always been present to some extent, but in recent years in the U.S. there's been a group of people proposing what they call "public sociology". One of the recent presidents of the American Sociological Association, Michael Burawoy, is perhaps the best known, but there's been a bunch of developments in both the U.S. and Europe. Then the question came up: So, what is the philosophical or normative status of this public sociology? Are you saying that sociology can after all tell us what should be the case? Or are you merely trying to help with the means to obtain certain ends that were established elsewhere? Suppose a politician says, "Inequalities are bad, what should we do about it?" Because you are a technical expert, you advise them to redistribute certain things in certain ways. It's just a technical calculation, as if you were an engineer. Or, rather, are you saying that sociology itself or the social sciences in general can make a contribution to what societies' ends should be?

\section{— How do you think an ethical person can survive in this unethical world?}

— I don't know that I can answer this.

\section{— Do you have any "recipes", suggestions? Or is this world not really as ethical as people may think?}

- I don't know that. The moral background approach doesn't have much to say about this sort of thing. It's not that I don't have ethical views or that I don't have good grounds to believe them and even to try to convince other people. But it's not really related to the moral background. The moral background steps outside of first-order morality and focuses on the conditions that make possible certain ethical actions, beliefs, norms, institutions, etc.

\section{— But if we all share more or less the same moral background, why some people are ethical and some people are not?}

- That's another thing. The relationship between the moral background level and first-order behavior is not a one-to-one correlation or correspondence. Background elements don't force you to act in any way. They are rather the conditions that need to be in place before both ethical and unethical actions can happen. We can think about different kinds of moral background elements fostering different values, or what background variables make it more likely that certain kinds of ethical behaviors happen. But, again, this wouldn't be a necessary relation.

\section{— Thank you very much for the interview!}

— Thank you! 


\section{References}

Abend G. (2014) The Moral Background: An Inquiry into the History of Business Ethics, Princeton: Princeton University Press.

Bazerman M., Gino F. (2012) Behavioral Ethics. Annual Review of Law and Social Science, no 8, pp. 85-104.

Durkheim É. (1982) The Rules of Sociological Method, New York: Free Press.

Hitlin S., Vaisey S. (eds) (2010) Handbook of the Sociology of Morality, New York: Springer.

Hitlin S., Vaisey S. (2013) The New Sociology of Morality. Annual Review of Sociology, vol. 39, no 1, pp. 51-68.

Isen A., Levin P. (1972) Effect of Feeling Good on Helping. Journal of Personality and Social Psychology, no 21, pp. 384-388.

Penner L., Dovidio J., Piliavin J., Schroeder D. (2005) Prosocial Behavior. Annual Review of Psychology, no 56 , pp. 365-392.

Simpson B., Willer R. (2015) Beyond Altruism. Annual Review of Sociology, no 41, pp. 43-63.

Treviño L., Nieuwenboer N., Kish-Gephart J. (2014) (Un)Ethical Behavior in Organizations. Annual Review of Psychology, no 65, pp. 635-660.

Received: August 11, 2016

Citation: Interview with Gabriel Abend "The Moral Background Makes the Play of Life Possible." Journal of Economic Sociology = Ekonomicheskaya sotsiologiya, vol. 17, no 4, pp. 206-215. Available at: https://ecsoc. hse.ru/2016-17-4.html (in Russian). 
Сентябрь 2016

Электронный журнал www.ecsoc.msses.ru www.ecsoc.hse.ru

ISSN 1726-3247

\section{Адрес редакции}

101000, Россия,

г. Москва,

ул. Мясницкая, д. 20, комн. 406 тел.: (495) 628-48-86 email: ecsoc@hse.ru

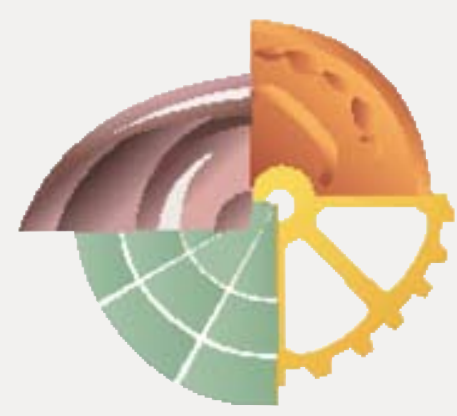

Journal of Economic Sociology Vol. 17. No 4.

September 2016

Electronic journal www.ecsoc.msses.ru www.ecsoc.hse.ru

ISSN 1726-3247

\section{Contacts}

20 Myasnitskaya street, room 406 101000 Moscow, Russian Federation phone: +7 (495) 628-48-86 email: ecsoc@hse.ru

\section{Доступ к журналу}

- Доступ ко всем номерам журнала - постоянный, свободный и бесплатный.

- Каждый номер содержится в едином файле (10-12 п. л. в PDF).

- Если хотите, чтобы Вас оповещали о выходе очередного номера, пожалуйста, заполните форму подписки: https:/www.hse.ru/expresspolls/ poll/23725626.html

\section{Open Access Policy}

- All issues of the Journal of Economic Sociology are always open and free access.

- Each entire issue is downloadable as a single PDF file.

- If you wish to receive notification when new issues are published, please fill out the following form: https://www.hse.ru/expresspolls/poll/23725626.html 